\title{
Reconstructing Neogene climate and glacial history of \\ Southern McMurdo Sound, Antarctica
}

By Libby Galbraith

\author{
A thesis submitted to \\ Victoria University of Wellington \\ in partial fulfilment of the requirements for the degree of \\ Master of Science \\ in Geology
}

Antarctic Research Centre

Victoria University of Wellington

2017 
1) P a g e 


\begin{abstract}
$\underline{\text { Abstract }}$
Understanding the glacial changes that have occurred in southern McMurdo Sound throughout the Neogene makes an important contribution to reconstructing Antarctic ice volume changes during past periods of climatic warmth, and provides insight into future possible response of the ice sheet. Fossiliferous glacimarine deposits previously identified throughout McMurdo Sound have provided inferences on past changes in ice volume and the implications for global sea level. This study investigates new stratigraphic sections comprising fossiliferous glacimarine sediments from two locations on the flanks of Mount Discovery and one on Brown Peninsula at $\sim 150 \mathrm{~m}$ above present day sea-level. The aim of this thesis is to undertake a sedimentological, facies and glacimarine sequence stratigraphic analysis together with a quantitative assessment of the constituent micro and macrofossils in order to determine depositional processes, changes in environment and implications for glacial variability in the southern McMurdo Sound. Up to four distinct sedimentary cycles are evident in the Mt Discovery sections with each cycle consisting of:
\end{abstract}

1. A basal glacial surface of erosion (GSE) or its correlative conformity (CC) seaward of the grounding line, displaying an abrupt transition from a more distal facies to a more proximal facies.

2. A sharp-based massive diamictite displaying physical intermixing of subjacent lithologies, intra formational clasts, soft sediment deformation features, clast rotation features, and a lack of bioturbation, interpreted as subglacial, or in very close proximity to a marine grounding line. In some cases stratified diamictites overly correlative conformities displaying clast alignment, graded beds, and weak decimeter scale parallel bedding in the matrix, interpreted as grounding-line proximal sediment gravity flows or rain-out from ice melt.

3. In some cases, the diamictite passes gradationally-upwards or is sharply overlain by a conglomerate representing appearance of glacimarine fluvio-deltaic deposition or debris flows as the glacier grounding line begins to retreat.

4. Conglomerates are overlain, often sharply, by hemipelagic laminated or massive mudstone and represent the most ice distal and marine part of the sequence at the interglacial minima.

5. A proglacial facies succession is sometimes preserved below the GSE or correlative conformity marking the top of the sequence and usually consists of a transition from mudstone facies into grounding zone proximal conglomerates during re-advance of the grounding line.

Lithofacies analysis supported by sediment grainsize, the results of a foraminiferal census and macrofaunal identifications conducted on each facies imply deposition on the continental shelf in depths of up to $400 \mathrm{~m}$, during oscillations in the proximity of a marine grounding line.

Radiocarbon dating of constituent macrofauna (barnacle plates) reported only background ${ }^{14} \mathrm{C}$ implying an age of deposition older than the Last Glacial Maximum. The present day elevation of the site and a model developed here using glacio-iostatic loading and unloading implies that the Mt Discovery sites have been above sea-level for approximately the last $~ 2.7 \mathrm{Ma}$. Given their inferred association with Scallop Hill Formation and faunal similarity to sequences in the nearby ANDRILL drill cores, a Pliocene age is considered most likely. This finding is consistent with previous investigations that indicate a dynamic, sub-polar marine-terminating ice sheet margin in Southern McMurdo Sound during the Pliocene, with periods of open ice shelf free conditions potentially associated with more frequent regional collapse and retreat events of a marine-based ice sheet in the Ross Sea embayment. 
3| P a g e 


\section{Acknowledgements}

From the ashes of disaster grow the roses of success.

The meaning of this thesis extends far beyond the pages before you. I am eternally grateful to Tim Naish for investing in me when I could only offer little in return except the promise to make every second of this incredible opportunity count, and to Richard Levy for allowing me to have a place in Antarctica's history. Few people get to feel the majesty that is Antarctica, and the magnitude of this truly humbling and rewarding experience will be with me forever. Credit must also go to the many kind faces I have encountered along the way who have made finishing this project possible, there is no I in Team and I could not have done this alone. Thanks especially to my mum and sister, Michelle Dow, Randall McDonnell, Hugh Morgans, Alan Beu, John Buckeridge, and Dougall Townsend, for their thoughtful contributions to this study.

This thesis is dedicated in memorium to Major Alister (Mac) McColl and Keith Garrett. Though my memories of Scott Base may now be bittersweet, I am lucky to have met you both.

Where the glacier meets the sky, the land ceases to be earthly, and the earth becomes one with the heavens; no sorrows live there anymore, and therefore joy is not necessary; beauty alone reigns there, beyond all demands.

- Halldór Laxness, The Beauty of the Skies. 


\section{Table of contents}

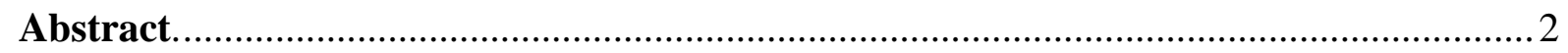

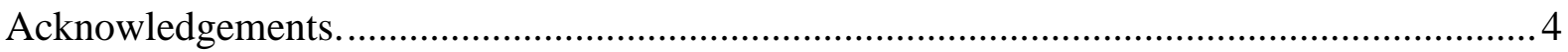

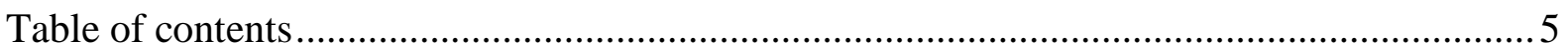

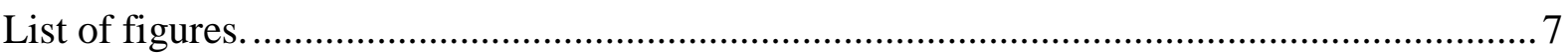

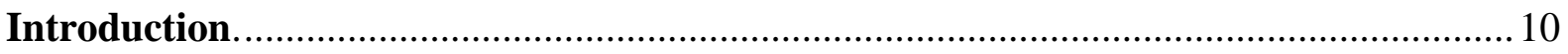

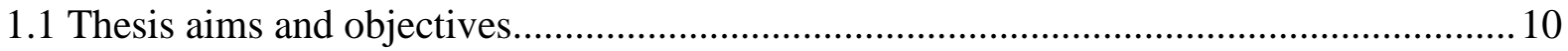

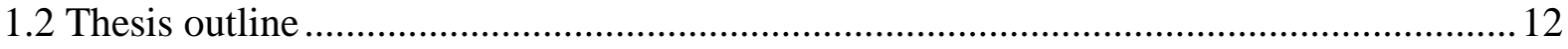

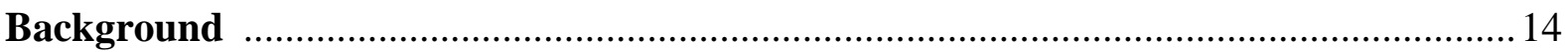

2.1 Known outcrops of Neogene and Quaternary fossiliferous glacimarine sediments in

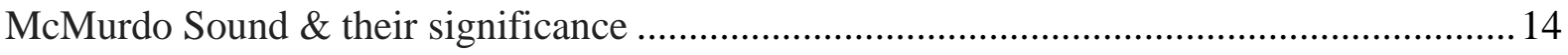

2.2 Global records of climate and sea-level change during the Pliocene-Pleistocene.............22

2.3 Antarctic geological drill core records of Neogene ice volume change in the Ross Sea...33

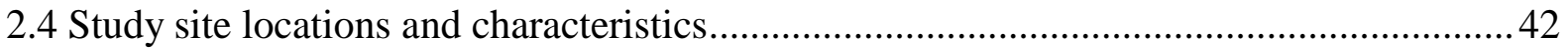

Methodology and background to approaches being used ........................................ 48

3.1 Field work: sampling and stratigraphic description.................................................. 48

3.2 Sediment texture and facies analysis as an indicator of grounding line variability ...........49

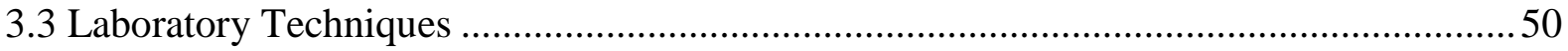

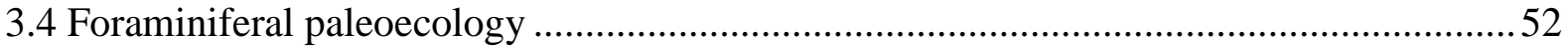

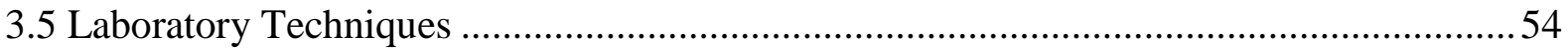

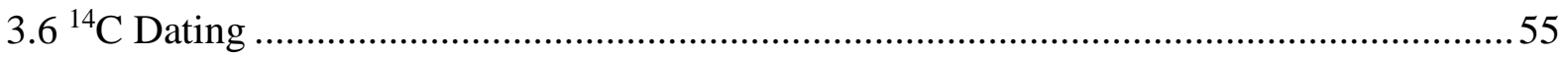

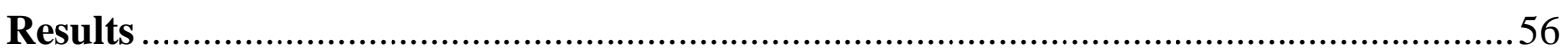

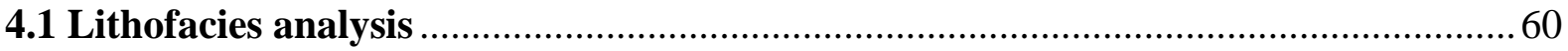

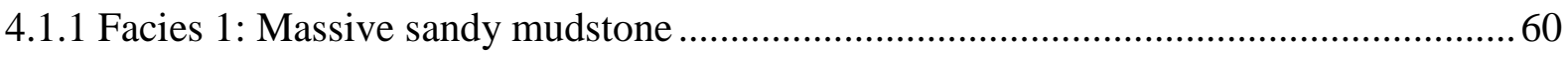

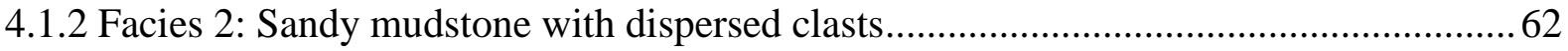

4.1.3 Facies 3 and 4: Clast- and matrix-supported conglomerate......................................... 64

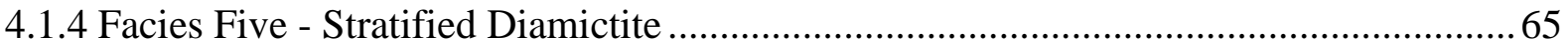

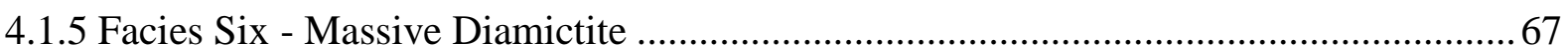

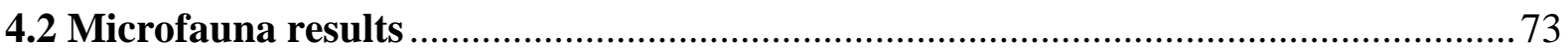




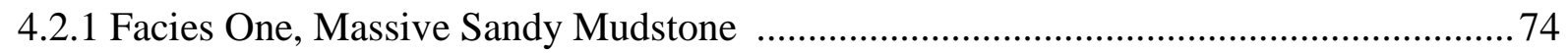

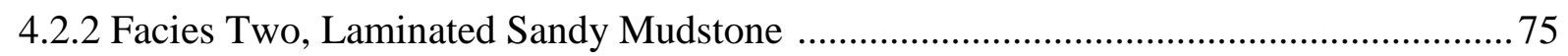

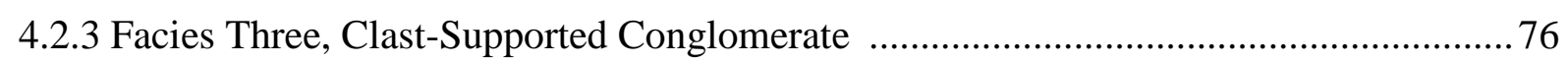

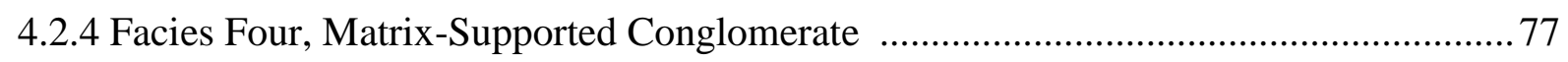

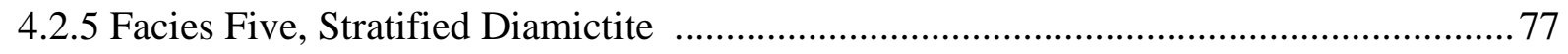

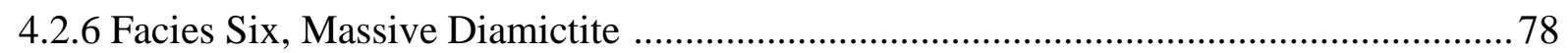

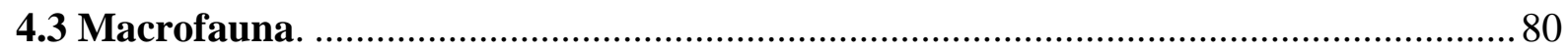

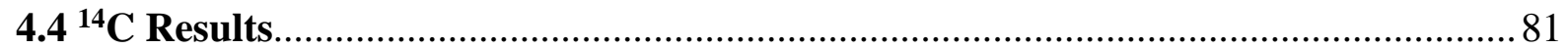

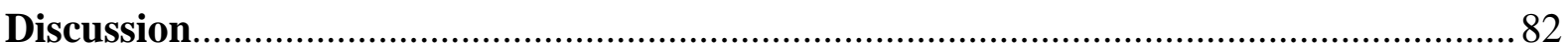

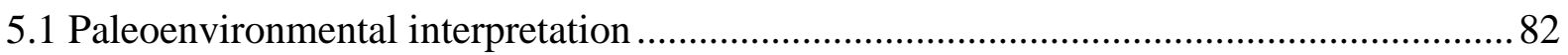

5.2 Depositional model for the Mt Discovery glacimarine deposits .................................... 85

5.3 Timing of Deposition and Paleoenvironmental Significance ......................................... 89

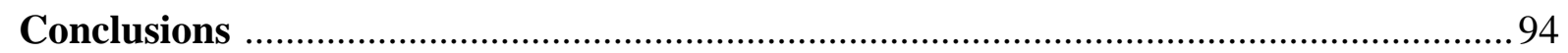

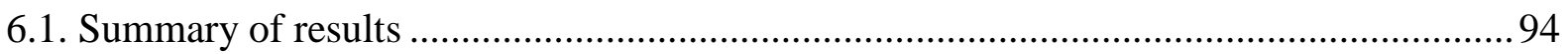

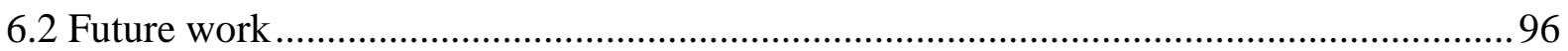

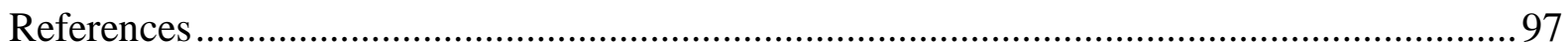

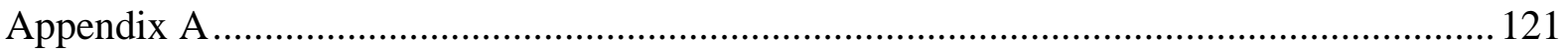

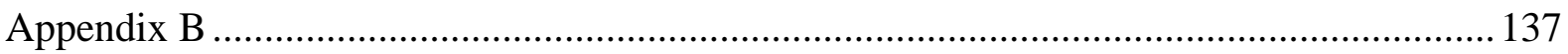

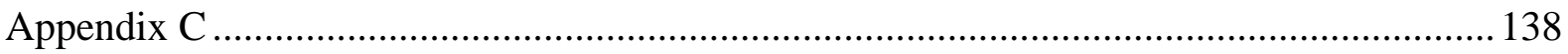




\section{$\underline{\text { List of Figures }}$}

Figure 2.1: Marine fossil collection sites in McMurdo Sound; both pre-1958 British Antarctic Expeditions sites and post-1958 NZ expedition sites (Speden, 1962).

Figure 2.2: VUWAE 20 locations of Scallop Hill Formation identified on Brown Peninsula (Eggers, 1979).

Figure 2.3: Stratigraphic column for the in-place Scallop Hill Formation deposit location A on Fig. 2.2 (Eggers, 1979)

Figure 2.4: Fragments of the extinct Zygochlamys anderssoni (Hennig) characteristic of the Scallop Hill Formation (Speden, 1962).

Figure 2.5: Oxygen and carbon isotope compositions of aragonite cement and calcareous fossils from the Scallop Hill Formation (Eggers, 1979).

Figure 2.6: Characteristic fauna of the Taylor Formation from surface deposits near the Dailey Islands in McMurdo Sound (Buckeridge, 1989).

Figure 2.7 Comparison of data and multi-model mean (MMM) simulations for the Mid-

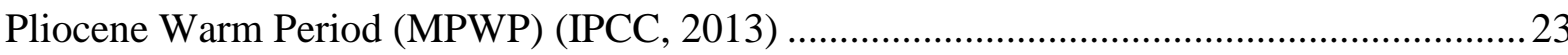

Figure 2.8: Comparison of late Pliocene sea-level estimates from Miller et al., (2012)........ 24

Figure 2.9: 5 myr simulation of ice volume through to the Pliocene to present. (Lisiecki and

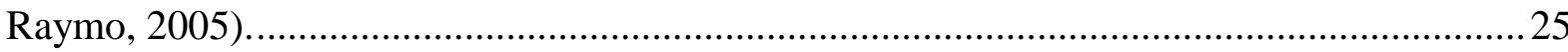

Figure 2.10: Present-day oceanographic configuration of the Atlantic Sector of the Antarctic region. (Flores and Sierro, 2007).

Figure 2.11: Total abundance of coccolithophores at ODP Site 1094 vs. orbital eccentricity and insolation (Laskar, 1990) (Flores and Sierro, 2007).

Figure 2.12: Paleoceanographic configuration of the Atlantic Sector of the Antarctic region during MIS31 (Flores and Sierro, 2007).

Figure 2.13: Reconstructions of LIG relative sea level along the coast of Western Australia based on in-situ coral elevations (Dutton and Lambeck, 2012; IPCC, 2013).

Figure 2.14: Proxy-derived estimate of GMSL rise based on a geographic database of widely dispersed sea level indicators (Kopp et al., 2013; IPCC, 2013) ............................................ 30

Figure 2.15: Change in GMSL in LIG simulations (DeConto and Pollard, 2016).

Figure 2.16: Location of the Cape Roberts Project drill sites and sites previously drilled in the McMurdo Sound region (Barrett et al., 2995).

Figure 2.17: Site setting for the AND-1B MIS and AND-2A SMS drill holes (Naish et al., 2007).

Figure 2.18: An example of the lithostratigraphic units observed throughout AND-1B. (Naish et al., 2009).

Figure 2.19: Facies stacking pattern and idealised interpretation of a complete glacimarine sequence occurring within the AND-2A sedimentary record (Fielding et al., 2011)..............38

Figure 2.20: Vertical occurrence of foraminiferal assemblages in middle Miocene and Pliocene sediments within the AND-2A core (Patterson and Ishman, 2012). 
Figure 2.21: Simulated future scenarios with elevated greenhouse gas emissions (DeConto and Pollard, 2016).

Figure 2.22: Study area encompassing Mount Discovery and Brown Peninsula, southern

McMurdo Sound (Wilson et al., 2000).

Figure 2.23: USGS topographic map showing sample locations (DO1A and DO3A) on the flanks of Mount Discovery, McMurdo Sound.

Figure 2.24: USGS topographic map of sample locations on Brown Peninsula, McMurdo Sound

Figure 2.25: Surface topography on the northern face of Mount Discovery surrounding glacimarine sequence DO1A.

Figure 3.1: Trenched stratigraphic section of DO3A.

Figure 3.2: Underlying in-situ stratigraphy at $30-40 \mathrm{~cm}$ depth prior to trenching DO3A...... 49

Figure 3.3: Classification scheme used for poorly sorted terrigenous clastic sediments containing gravel sized clasts.

Figure 3.4: Comparison of the mud content or original sample measurements and repeat samples

Figure 4.1: DO1A lithologic log. .57

Figure 4.2: DO3A lithologic log. 58

Figure 4.3: $\mathrm{BO} 1 \mathrm{AB}$ composite lithologic log.

Table 4.4: Summarised table of the glacimarine facies identified throughout DO1A/3A and $\mathrm{BO} 1 \mathrm{AB}$.

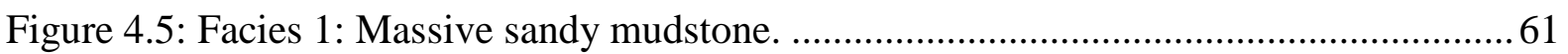

Figure 4.6: Facies 2: Sandy mudstone with dispersed to common clasts.............................63

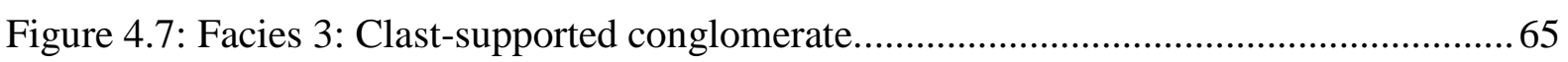

Figure 4.8: Facies 4: Matrix-supported conglomerate..................................................... 65

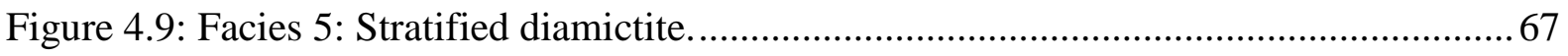

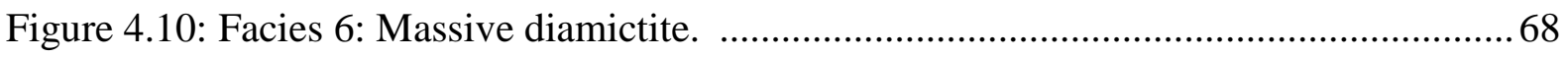

Figure 4.11: Grainsize distributions of the fine fraction from DO1A Facies 1-6. ..................69

Figure 4.12: Grainsize distributions of the fine fraction from DO3A Facies 1-6. ................. 70

Figure 4.13: Grainsize distributions of the fine fraction from BO1AB Facies 4 and 5. ........ 71

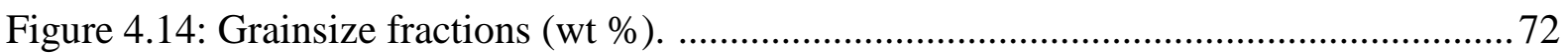

Figure 4.15: L-R: Ehrenbergina glabra; Trifarina pauperata; Lenticulina gibba;

Neogloboquadrina pachyderma; Cornuspiroides expansus; Patellina Antarctica................. 73

Figure: 4.16: Additional material recovered from microfauna samples ................................. 74

Figure 4.17: Foraminifera species and additional microfossils recovered from Facies 1;

DO1A $350 \mathrm{~cm}$ .75 
Figure 4.18: Foraminifera species and additional microfossils recovered from Facies 2; DO3A $390 \mathrm{~cm}$

Figure 4.19: Foraminifera species and additional microfossils recovered from Facies 3; DO1A $320 \mathrm{~cm}$

Figure 4.20: Foraminifera species and additional microfossils recovered from Facies 4; DO3A $120 \mathrm{~cm}$.

Figure 4.21: Foraminifera species and additional microfossils recovered from Facies 5; DO3A $60 \mathrm{~cm}$

Figure 4.22: Foraminifera species and additional microfossils recovered from Facies 6; DO1A $590 \mathrm{~cm}$

Figure 4.23: Foraminifera species and additional microfossils recovered from BO1AB 120 $\mathrm{cm}$

Figure 4.24: Foraminifera species and additional microfossils recovered from BO1AB 180 $\mathrm{cm}$.

Figure 4.25: L-R: Dentalium (genus unidentifiable); Eumetula delecta; Naticidae prolacuna;

Pareuthria plicatula; Powellisetia; solitary coral Gardineria antarctica.

Figure 4.26: Fragments of the Antarctic cirripede Bathylasma corolliforme.

Figure 4.27: Measurements of ${ }^{14} \mathrm{C}$ found to be indistinguishable from $\mathrm{C}^{14}$-free background materials prepared and measured concurrently with each sample.

Figure 5.1: Idealised sequence motif represented by the Mt Discovery glacimarine deposits.

Figure 5.2: Inferred locations of Facies 1-6 along a schematic shore-normal profile from ice proximal to ice distal depositional environments.

Figure 5.3: Modelled changes in relative sea level along the coast of Southern Victoria Land throughout late Neogene (Levy et al., 2012).

Figure 5.4: Bed elevation of the Mt Discovery sites with respect to both present day sea-level during the LGM, and Marine Isotope Stage M2 glaciation and subsequent deglaciation to the M1 interglacial between 3.310-3.260 Ma. 


\section{Introduction}

\subsection{Thesis aims and objectives}

This study is focused on sediments recovered from isolated outcrops of fossiliferous glacimarine deposits found up to 200 m elevation on the flanks of Mount Discovery and Brown Peninsula volcanoes in southern McMurdo Sound, Antarctica. Investigating the geologic record of southern McMurdo Sound provides a unique opportunity to reconstruct paleoenvironmental conditions in an ice-proximal depositional setting. The late Neogene geologic record is of particular importance as it contains a number of shifts between interglacial and glacial regimes (Barrett and Hambrey, 1992; McKay et al., 2009). Fluctuations in the state of Antarctica's cryosphere and climate throughout the late Neogene are inferred to have had a profound effect on the marine and terrestrial realm (Flowers and Kennett, 1994; Barrett, 2012). Changes in Antarctic ice volume contribute to changes global sea level, Earth's albedo, and ocean circulation. Previous on-land geological records of a dynamic Neogene ice sheet in southern McMurdo Sound exist in the form of extensive geological and geomorphological surveying (e.g. Speden, 1962; Mercer, 1968, 1972; Vella, 1969; Mayewski, 1975; Eggers, 1979; Denton et al., 1984 Webb et al., 1984; Webb and Hardwood, 1991; Buckeridge, 1989), as well as from drilling projects in the Ross Sea region of Antarctica (e.g. Webb et al., 1984; Pickard et al., 1988; Harwood and Webb, 1994; Hambrey and McKelvey, 1999; McKay et al., 2009). Evidence of changes in the Southern Ocean regime during this time are also suggested (e.g. Flowers and Kennett, 1994; Dowsett et al., 1996; Crampton et al., 2016).

The disintegration of ice shelves in the Antarctic Peninsula region has been touted as an early response to prolonged warming and a precursor to further loss of land-based ice (Doake and Vaughan, 1991; Scambos et al., 2000; Domack et al., 2005), just as Mercer (1978; 1979) first predicted. Understanding the response of Antarctica's ice sheets to previous warmer-thanpresent intervals in Earth's history is important given the estimated warming that is predicted to take place by the end of the century (e.g. Naish and Zwartz, 2012; Dowsett et al., 2012). Determining future climate scenarios is reliant on a precise knowledge of the role and feedbacks related to changes in Antarctica's ice volume on the Earth system (i.e. oceanic and atmospheric). 
The primary objective of this study is to therefore establish a robust sequence of advance, retreat, and re-advance, of a marine-terminating ice margin at a single location within southern McMurdo Sound that can be integrated with existing continental, regional drillcore and global records. The main goal is to contribute additional information on the history of ice in southern McMurdo Sound, as well as any associated changes in environmental conditions. Interpretations are based on 2 main approaches:

1. The use of sediment texture as an indication of distance from a marine-terminating ice margin in southern McMurdo Sound. This follows similar attempts made with sediments from the Scallop Hill and Taylor Formations (Speden, 1962; Vella, 1969; Eggers, 1975), and interpretations are largely based on the analysis of drillcore sediments recovered by the ANDRILL Program (e.g. Naish et al., 2006; Krissek et al., 2007; McKay et al., 2009). This study recognises that major changes in lithology may arise from a shift in the sedimentary environment between ice-distal and ice-proximal conditions (McKay et al., 2009). Changes in sediment texture and lithofacies are used to establish an idealised sequence motif of grounding line advance and retreat for the glacimarine successions, as well as to develop a depositional model that accounts for several fluctuations of a marine ice sheet grounding zone within southern McMurdo Sound.

2. Fossil foraminifera and marine invertebrates provide another means of reconstructing the depositional environment in a way that is complementary to, and independent of sediment texture. Inferences made regarding changes in water depths and paleoenvironmental conditions are based on the modern distribution of foraminifera around Antarctica (e.g. Ward et al, 1987; Ishman and Szymcek, 2003), as well as on correlations with the faunal record recovered from previous drilling projects in McMurdo Sound (e.g. Leckie and Webb; 1983; Strong and Webb, 2006; Patterson and Ishman, 2012).

The paleoenvironmental significance of the glacimarine sequences investigated in this study is largely dependent on the time interval they represent. An additional objective of this study is to therefore try and constrain the time in which these sequences were deposited. This study applies traditional radiometric and biostratigraphic approaches to determine the age of the sediments. It also applies an innovative indirect method that interprets and age based on the elevation history of the depositional sites, in terms of the viscoelastic response of the crust due 
to glacio-isostatic loading and rebound and the secondary potential influence of uplift associated with glacial incision and erosion in the adjacent Transantarctic Mountains (e.g. Stern et al., 2005).

\subsection{Thesis outline}

This thesis is composed of 6 chapters, including the introductory chapter. Chapter 1 outlines the primary objectives and reasoning behind this study, as well as highlighting the potential contribution this study can make towards enhancing the geologic record of southern McMurdo Sound. Chapter 2 explores additional outcrops of fossiliferous glacimarine deposits previously identified throughout McMurdo Sound and the wider Dry Valleys region, and outlines existing evidence for a dynamic glacial regime operating during the late Neogene. Chapter 2 goes on to discuss changes in global sea level and climate, specifically focusing on the record of Antarctic ice volume during past warm intervals (i.e. mid-Pliocene, and Marine Isotope Stages 31, 11, and 5e). Chapter 2 further details direct evidence of changes in Antarctic ice volume inferred from drilling projects in the Ross Sea region of Antarctica. The aim of this background information is to place the objectives of this study within a regional and global context, i.e., why do changes in Antarctic ice volume matter. Chapter 2 concludes with study location and key site setting information.

Methodology and background to approaches are outlined in Chapter 3. Field work and sampling practices are first described, followed by an explanation behind the use of sediment texture and lithofacies analysis as an indication of grounding line variability. Chapter 3 also includes the reasoning behind using benthic foraminifera for paleoenvironmental interpretations, as well as radiocarbon dating of shell material. Laboratory techniques for each method are also discussed.

Chapter 4 presents the results of the lithostratigraphic, facies and sequence stratigraphic analyses. Chapter 4 also provides results from quantitative microfossil and macrofossil analysis, as well as radiocarbon results. Interpretations for these results are discussed in Chapter 5.

In Chapter 5, the range of possible environmental conditions and water depths reflected by the microfossil and macrofossil assemblages are discussed through comparisons with modern faunal assemblages and drillcore records from the Ross Sea region of Antarctica. These 
paleoenvironmental interpretations are combined with grainsize and lithofacies results to produce a glacimarine depositional model for the deposits studied. The depositional model discussed in Chapter 5 includes an idealised sequence motif of ice advance, retreat, and readvance, as well as a schematic shore-normal profile from ice proximal to ice distal depositional environments showing the inferred location of each facies. Chapter 5 concludes with an uplift history for the deposits, based on a combination of glacio-isostatic and tectonic processes. Constraining the time interval that these deposits is significant as it allows correlations or comparisons to be made with other known records of environmental change.

Chapter 6 provides a brief summary of the results presented in this study. Based on the uplift model discussed in Chapter 5, lithofacies analysis and paleoenvironmental interpretations, inferences are made regarding changes in ice volume in southern McMurdo Sound during warmer-than-present climate conditions and their broader implications. 


\section{Background}

\subsection{Known outcrops of Neogene and Quaternary fossiliferous glacimarine sediments in McMurdo Sound \& their significance}

More than a century has passed since Norwegian explorer C. A. Larsen first identified rocks bearing Cenozoic marine invertebrate fossils on the Antarctica Peninsula's Seymour Island. Larsen's discovery marked an important turning point in understanding Antarctica's glacial history, providing physical evidence of an environment unlike the ice-covered continent we know of today (Webb, 1990). A number of early $20^{\text {th }}$ Century expeditions set off for Antarctica following Larsen's revelation, beginning with the Swedish South Polar Expedition who embarked in 1901 intent on establishing the Cenozoic geology of Seymour and Cockburn Islands, while the 1901-1907 Scott and Shackleton expeditions are responsible for characterising a number of Quaternary-aged deposits in the Ross Sea region (Fig. 2.1) (Webb, 1990).

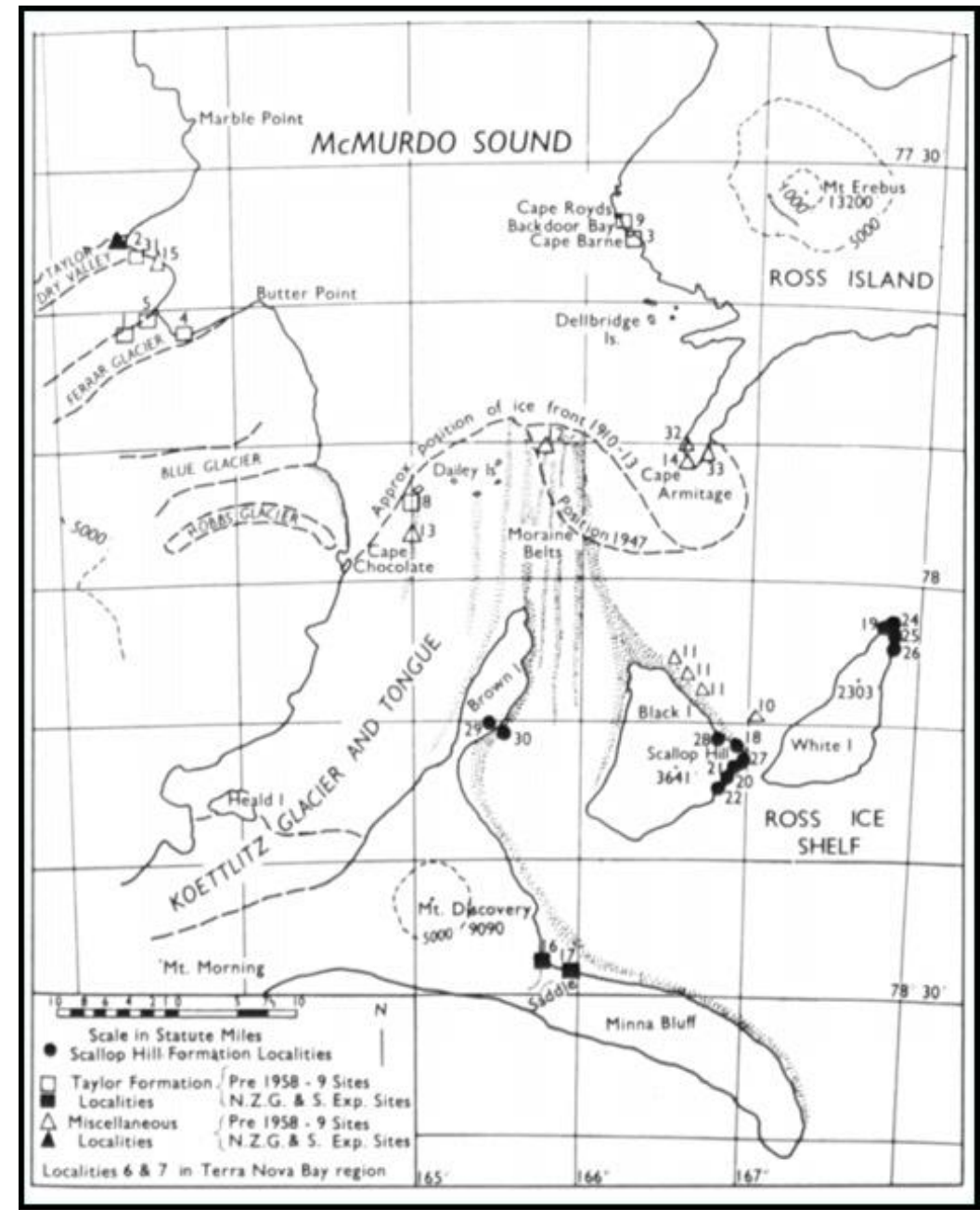

Figure 2.1: Marine fossil collection sites in McMurdo Sound; both pre-1958 British Antarctic Expeditions sites and post-1958 NZ expedition sites (Speden, 1962).

Despite initial efforts to demystify Antarctica's paleoclimate, decades of inactivity transpired until the 1957 International Geophysical Year (Webb, 1990). In the years that followed, members of the New Zealand Geological Survey and Victoria University of Wellington Antarctic Expeditions (VUWAE) returned to McMurdo Sound to sample and describe 
fossiliferous deposits from several new isolated localities widely dispersed across the area (Fig. 2.1).

The first two of these expeditions (VUWAE 1 and VUWAE 2) took place in the austral summers of 1957-58/1958-59 and produced the earliest reports of topographical, geological, biological, and geophysical, observations recorded in extensive ice-free areas of southern Victoria Land. The return of VUWAE 3 in 1959-60 expanded upon what had already been established by the two previous expeditions and altogether successfully mapped an area of icefree country in excess of 2500 square miles (Balham et al., 1960). By this point in time a general geological history for the Wright Valley-Victoria Valley system had been determined, providing detailed descriptions of Precambrian marbles and schists, Palaeozoic-Mesozoic Beacon Group sediments and Ferrar dolerite sills, Cenozoic kenyte, basalt, and trachyte lavas, and identifying at least four episodes of Quaternary glacial incision and deposition of moraines (Balham et al., 1960). The following decade saw investigations into Beacon Group sediments carried out along the entire length of Victoria Land, making it possible to correlate stratigraphy over great differences (Bull et al., 1961; Wellman et al., 1964; Vella et al., 1965; Wellman et al., 1967).

Meanwhile, efforts to investigate the occurrence of Neogene marine invertebrate fossiliferous deposits in southern McMurdo Sound resulted in the discovery of over 30 new deposits with sufficient faunal differences allowing for the separation of two distinct fossiliferous horizons associated with glacial morraines, known as the Pliocene-aged Scallop Hill Formation and the younger Holocene-aged Taylor Formation, each of which reflect the extent of different glacial advances and retreats in the region over time (Speden, 1962; Vella, 1969; Eggers, 1979; Buckeridge, 1989). The type locality for the Scallop Hill Formation lies on the east corner of Black Island at Cape Spirit (Fig. 2.1), where it is underlain by an irregular surface cut in trachyte that has been dated at ca. 3.8 myr B.P. (Kyle et al, 1979). The formation is characterised as fossiliferous beds of tuffaceous conglomerate and grit fragments intimately associated with glacial moraine remains (Speden, 1962). Outcrops of the Scallop Hill Formation have since been found widely distributed across the islands of the Ross Archipelago (Cole et al., 1968; Vella, 1969; Cole at al., 1971), and the deposit has been correlated with Pecten Gravels from the Wright Valley (Webb, 1972; 1974).

Victoria University of Wellington Antarctic Expedition (VUWAE) 20 returned to the area once more in the summer of 1975, spending six days tracing the lateral extent of the Scallop Hill 
Formation around the northern tip of Brown Peninsula, in an attempt to further establish the stratigraphy, timing, and genesis of the formation (Fig. 2.2) (Eggers, 1979). During their time on Brown Peninsula, VUWAE 20 described and sampled several exposures of the formation, including one complete exposure of four metres of in-place stratigraphy in which Eggers (1979) was able to distinguish five distinct lithological units of volcanic breccia and tuffaceous detritus, with the fifth unit bearing well-preserved macro- and microfauna (Fig. 3) (Eggers, 1979). Eggers argues that the well-preserved fauna, low diversity of taxa, and dominance of a select few species at this site confirms the formation must be unmodified and in-situ, allowing approximate constraints to be placed on the maximum and minimum timing of genesis for the Scallop Hill Formation. The Aurora Trachyte Formation (Cole and Ewart, 1968) lies stratigraphically beneath and has been radiometrically dated at 2.25 myr B.P., while overlying the formation are flows of the Nubian and Melania basalt formations, each dated at 2.2 and 2.1 myr B.P., respectively (Fig. 2.3) (Eggers, 1979). The age ranges suggested by the combination of volcanic and fossil evidence indicate that the Scallop Hill Formation must have been deposited between 3.8-2.1 myr B.P (Eggers, 1979).

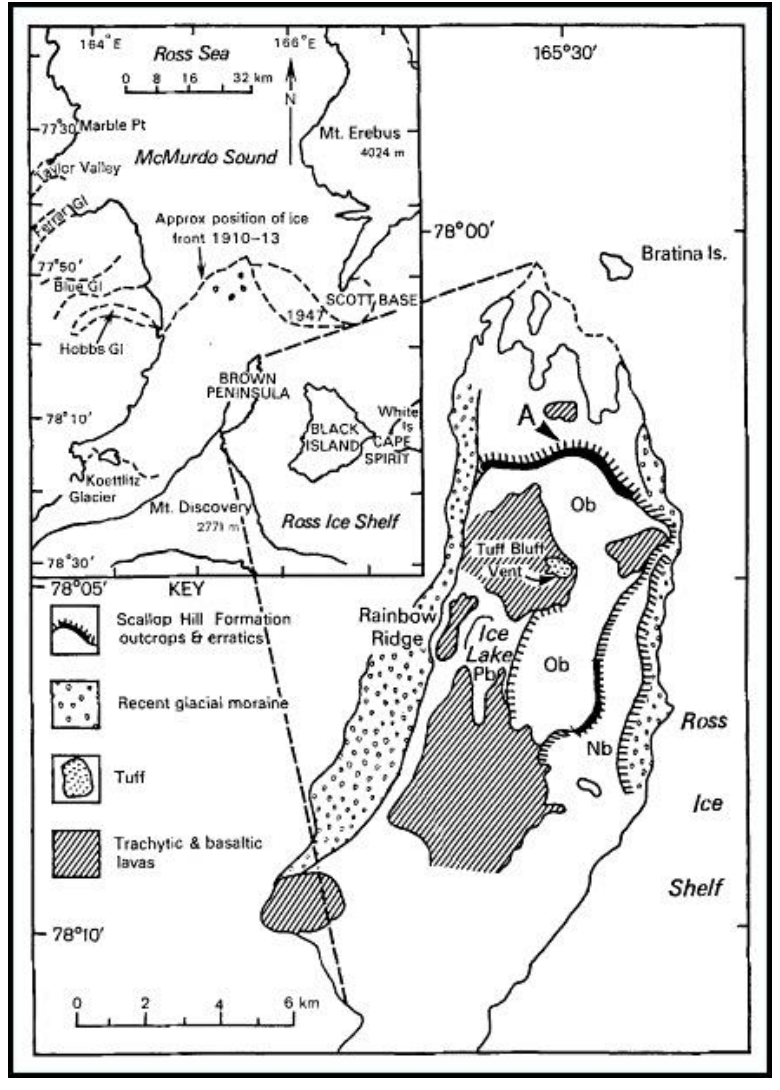

Figure 2.2: VUWAE 20 locations of Scallop Hill Formation identified on Brown Peninsula (Eggers, 1979).

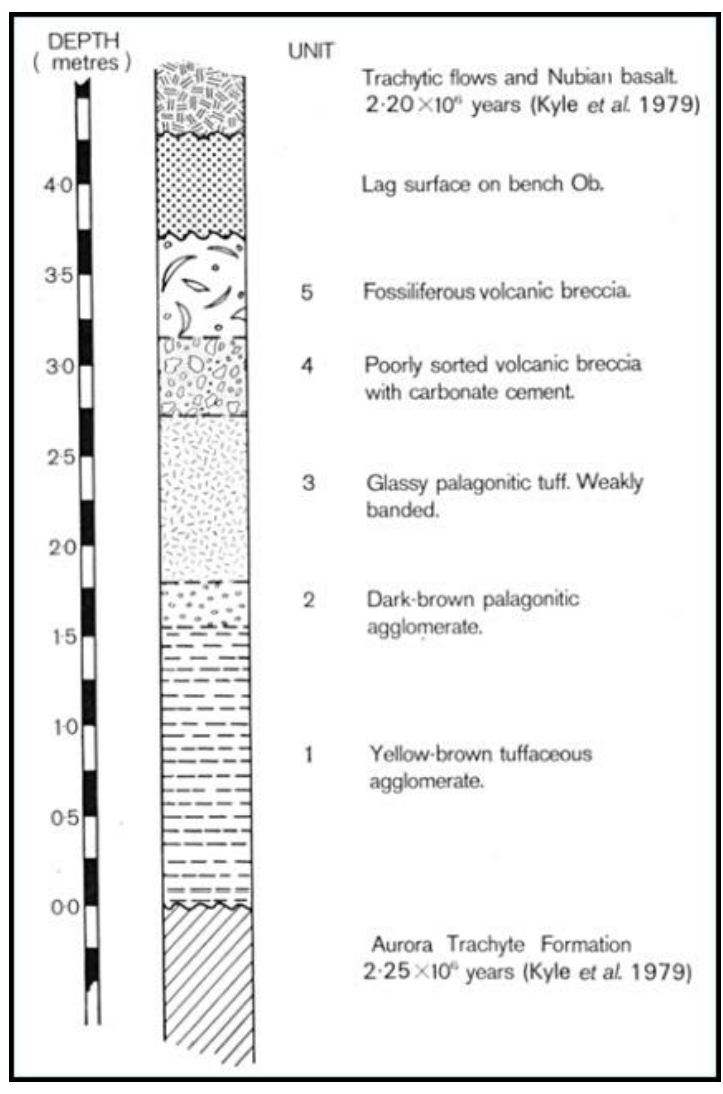

Figure 2.3: Stratigraphic column for the inplace Scallop Hill Formation deposit location A on Fig. 2.2 (Eggers, 1979) 
Extensive efforts to map and characterise the Scallop Hill Formation have returned an array of marine macrofauna that is reasonably low in diversity, predominantly consisting of the extinct Chlamys (Zygochlamys) anderssoni (Hennig) from which the deposit takes its name (Fig. 2.4), as well as Laternula sp., the coral Gardineria Antarctica, echinoid spines belonging to Sterecbinus neumayeri (Meissner), Odontaster tenuis (Koehler), and bryozoa colonies including Microporella ciliate (Pallas) and Neofungella claviformis (Speden, 1962; Vella, 1969; Eggers, 1979; Buckeridge, 1989). Microfauna present within the Scallop Hill Formation consist of foraminifera such as Cibicides, sp., Ehrenbergina glabra, and Globocassidulina subglossa, as well as ostracods, echinoid spines, sponge spicules, coral fragments, and plant matter. However, foraminifera in the Scallop Hill Formation are restricted to benthic species only, a characteristic Eggers (1979) attributes to an expanded West Antarctic Ice Sheet (WAIS) and a shallow calcium carbonate compensation depth, ultimately inhibiting the growth of planktonic species and instead allowing their benthonic counterparts to flourish in the gravelly substrate (Eggers, 1979). Excluding the extinct Chlamys anderssoni (Hennig), taxa found within the Scallop Hill Formation remain extant in today's Southern Ocean, and therefore are not age diagnostic, but do help with environmental interpretations (Speden, 1962).

In an attempt to try and determine ocean temperatures during the time of deposition, oxygen and carbon isotopic composition analyses were carried out on both fragments of the calcareous Chlamys anderssoni and fragments of the Recent Antarctic scallop Adamussium colbecki (Fig. 2.5) (Eggers. 1979). Adamussium colbecki returned a calculated oxygen isotopic temperature of $0.2^{\circ} \mathrm{C}$ which is consistent with present-day conditions beneath the Ross Ice Shelf, while Chlamys anderssoni yielded an oxygen isotope temperature of $2.0^{\circ} \mathrm{C}$ (Eggers, 1979), suggesting water temperatures varied from -2 to $+2{ }^{\circ} \mathrm{C}$ during the time in which Scallop Hill Formation was being deposited. These results show similarities to the shallow-marine fauna of the Wright Valley (Webb 1972; 1974), and have been compared to modern-day faunal assemblages found in several Alaskan and Canadian fiords, channels, and inshore glacimarine 
environments that all have a notable absence of planktonic taxa (Todd and Low, 1967 (Eggers, 1979).

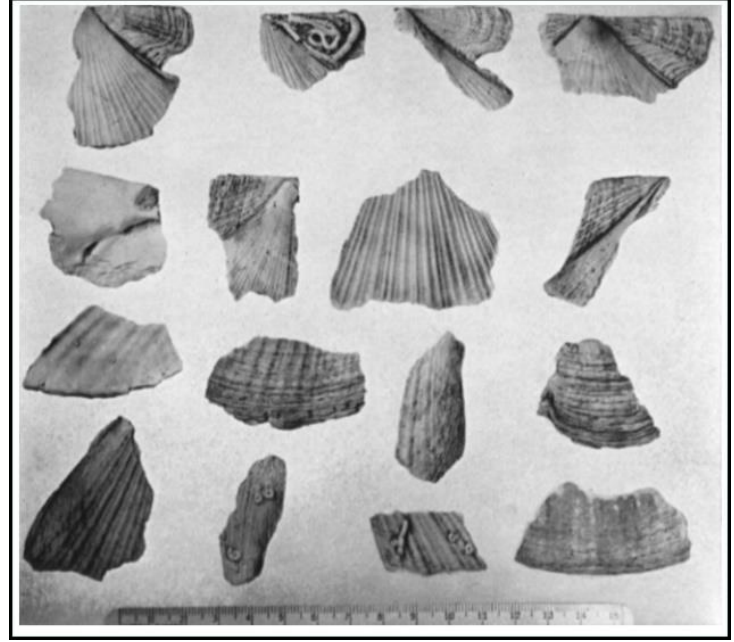

Figure 2.4: Fragments of the extinct Zygochlamys anderssoni (Hennig) characteristic of the Scallop Hill Formation (Speden, 1962).

\begin{tabular}{|c|c|c|}
\hline N125 & $\begin{array}{l}\delta_{\text {PDB }}{ }^{13} \mathrm{O} \\
\delta^{13} \mathrm{C} \\
\text { Temperature } \\
\text { Z-value }\end{array}$ & $\begin{array}{l}=4.44 \pm 0.17 \% \\
=1.76 \pm 0.05 \% \\
=0.2^{\circ} \pm 0.50^{\circ} \mathrm{C} \\
=133\end{array}$ \\
\hline N126 & $\begin{array}{l}\delta_{\text {PDB }}{ }^{18} \mathrm{O} \\
\delta^{13} \mathrm{C} \\
\text { Temperature } \\
\text { Z-value }\end{array}$ & $\begin{array}{l}=3 \cdot 86 \pm 0.04 \% \\
=-4.65 \pm 0.01 \% \\
=2.0^{\circ} \pm 0.13^{\circ} \mathrm{C} \\
=120\end{array}$ \\
\hline N127 & $\begin{array}{l}\delta_{\text {PDn }}{ }^{11} \mathrm{O} \\
\delta^{13} \mathrm{C} \\
\text { Temperature } \\
\text { Z-value }\end{array}$ & $\begin{array}{l}=3.85 \pm 0.1 \% \\
=5.52 \pm 0.1 \% \\
=2.0^{\circ} \pm 0.32{ }^{\circ} \mathrm{C} \\
=141\end{array}$ \\
\hline N128 & $\begin{array}{l}\delta_{\mathrm{PDB}}{ }^{13} \mathrm{O} \\
\delta^{13} \mathrm{C} \\
\text { Temperature } \\
\text { Z-value }\end{array}$ & $\begin{array}{l}=-23 \cdot 21 \pm 0.04 \% \\
=-3 \cdot 66 \pm 0 \cdot 04 \% \\
=191^{\circ} \pm 0.40^{\circ} \mathrm{C} \\
=108\end{array}$ \\
\hline \multicolumn{3}{|c|}{ 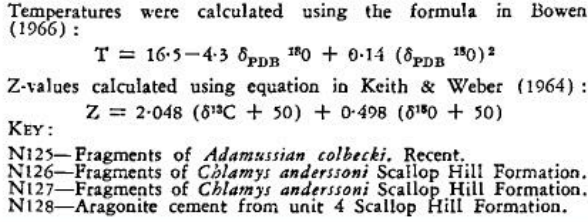 } \\
\hline
\end{tabular}

Figure 2.5: Oxygen and carbon isotope compositions of aragonite cement and calcareous fossils from the Scallop Hill Formation, and Recent Antarctic scallop Adamussian colbecki (Eggers, 1979). The temperature of 191 indicates precipitation of the aragonite was not in equilibrium with sea water (Eggers, 1979).

Eggers went on to propose that the volcanic breccia and tuffaceous detritus found throughout the Scallop Hill Formation was erupted onto the seafloor, hydrating the basaltic glass and forming palagonite (Eggers, 1979). Once this tephra material had cooled, a community of benthic marine taxa was able to take hold and thrive in the sand-silty substrate of this shallow inner-shelf marine environment that was "probably" no deeper than 100 m (Eggers, 1979). There is no definitive answer as to how the Scallop Hill Formation has reached its present-day elevation of 150 - $200 \mathrm{~m}$ above sea level (asl) on Brown Peninsula, but Eggers (1979) suggests that the most logical explanation must be a combination of glacioisostatic rebound and tectonic uplift. As this uplift began, the sediments became stranded in a supertidal environment during interstadial conditions, where the occasional flushing of seawater caused aragonite cement to precipitate both inside the tests of microfossils as well as completely enclosing others (Eggers, 1979).

The younger of the two marine deposits known to occur in McMurdo Sound was first identified by Priestly and Amitage in 1908 near the mouth of the Taylor Valley, situated above not within moraine, at an elevation of $15-18 \mathrm{~m}$ asl, and is subsequently named the Taylor Formation (Speden, 1962). The Taylor Formation is found at significantly lower elevations than the 
Pliocene-aged Scallop Hill Formation, with the former generally located closer to present-day shorelines, and remain largely unaffected by glaciation (Speden, 1962). The placement of these deposits overlying ice in unglaciated conditions suggest that the majority are of postglacial age and were most likely consigned to their current positions during the Last Glaciation (Speden, 1962). These differences in elevation and varying degrees of association with glacial moraines make it possible to distinguish between the Taylor Formation and the Scallop Hill Formation at a stratigraphic level, but they are not the only features that define a separation between the two marine remains (Buckeridge, 1989). The type locality for the Taylor Formation is defined as unconsolidated marine silts, sands, muds, and gravel, consisting of marine taxa dominated by the living species Adamussium colbecki (Smith), as well as Bathylasma corolliforme (Hoek), polychaete fragments, sponges, bryozoan remains, and the solitary coral Gardineria. The mollusc Adamussium is restricted to deposits of the Taylor Formation, just as Zygochlamys anderssoni is characteristic of the Scallop Hill Formation, providing another means of establishing a clear separation between the two formations (Speden, 1962; Eggers, 1979; Buckeridge, 1989). When compared to the Scallop Hill Formation, the Taylor Formation also exhibits greater abundance and increased diversity of marine fossils, with species further subdivided into two distinct faunal assemblages that reflect different depositional environments (Fig. 2.6) (Buckeridge, 1989).

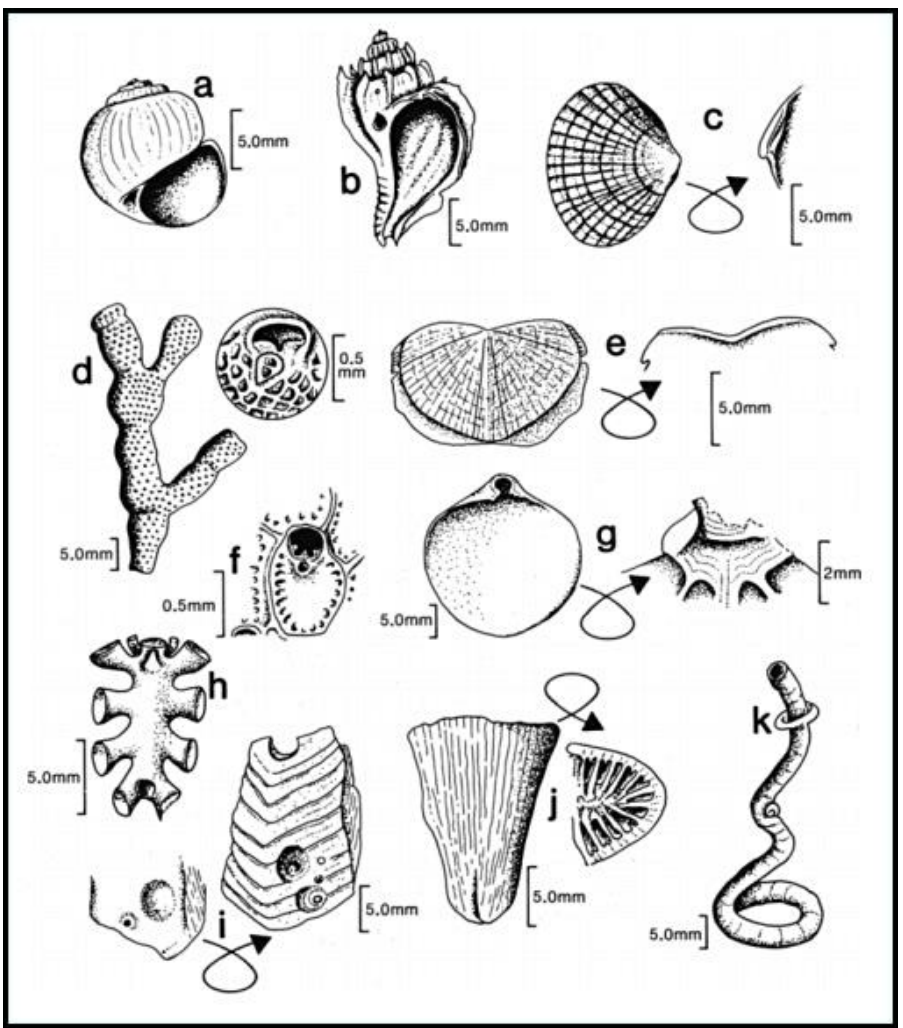

Figure 2.6: Characteristic fauna of the Taylor Formation from surface deposits near the Dailey Islands in McMurdo Sound. a) Amauropsis grisea (von Martens); b) Trophon longstaffi (Smith); c) Cyclocardia astartoides (von Martens), showing exterior and detail of interior umbonal area; di) Cellarinella rossi (Rogick) (escharifonn growth habit) dii) detail of $C$. rossi zooecium; e) Chaetopleura miranda (Theile), showing exterior and detail of interior; f) ?Smittoidea sp. (membranoporifonn growth habit); g) Magellania cf. M. venosa (Solander), showing pedicle valve (exterior) and incomplete brachial valve (interior) with detail of apical area; h) Colossendeis $c f . C$. robusta (Hoek). Dorsal view of prosoma of immature specimen; i) Bathylasma corolliforme (Hoek), showing exterior and interior (in part) with repaired predator boring; j) Caryophyllia antarctica (von Moranzeller), lateral and top view of an incomplete specimen; k) Polychaete tube, with Spirorbis sp. attached on centre left. (Buckeridge, 1989) 
The shallow water facies of the Taylor Formation was most likely deposited in waters less than $200 \mathrm{~m}$ deep, and is characterised by the dominance of Adamussium colbecki, polychaete tubes, sponges, and bryozoans, but in some locations the formation has also been found to contain the molluscs Amauropsis and Chlamys, and the brachiopod Magellania (Buckeridge, 1989). Whereas dominant fauna of the deep water facies are the cirripede Bathylasma corolliforme, and the solitary corals Gardineria and Caryophyllia, all of which occur at water depths greater than 200 m (Buckeridge, 1989). However, as is the case with the Scallop Hill Formation, many of the species identified within the Taylor Formation represent shallow water fauna of the present-day Ross Sea, providing little certainty that the depositional environments expressed throughout the Taylor Formation differ in some way to the modern day McMurdo Sound region (Buckeridge, 1989).

In addition to first discovering the Taylor Formation, David and Priestly (1914) proposed the two earliest alternative methods for the origin of the deposits (Speden, 1962). Their first theory argues that the deposits owe their occurrence to the up-thrusting of marine muds and glacial debris by moving ice, while the second hypothesis suggests an increase in ice density is responsible for depressing an entrapped moraine to such an extent that it formed on the sea floor upon which the marine remains were deposited (Speden, 1962). Speden reports that upthrusting and up-ploughing of sediments by ice is a common phenomenon across the McMurdo Sound region, and can be used to explain most occurrences of the Taylor Formation. In some places the deposits also appear to have been uplifted via glacial isostatic adjustment of the lithosphere and raised relative to present-day sea level in the same manner as which the Scallop Hill Formation is believed to have been elevated (Speden, 1962; Buckeridge, 1989). These explanations although geologically reasonable, have not been substantiated fully and remain an interpretation at best (Vella, 1969).

Distributed further throughout the Transantarctic Mountains and valleys in between are additional outcrops of terrestrial glacial deposits belonging to the Sirius Group (Mercer, 1968, 1972; McKelvey et al., 1991; Goff et al., 2002). Sediments dominated by diamictite facies are inferred to be of wet-based glacial origin deposited by ice flowing from the interior of East Antarctica (Mayewski, 1975; Denton et al., 1984; McKay et al., 2008). Some deposits in the Sirius Group have also been found to contain Nothofagus beardmorensis fossil leaves, stems, and pollen (Francis and Hill, 1996). These faunal remains are comparable to the modern Nothofagus antarctica found growing up to $700 \mathrm{~m}$ elevation in South America and reflect annual temperatures of $-12^{\circ} \mathrm{C}$ and summer growing season temperatures around $5^{\circ} \mathrm{C}$ (Francis 
and Hill, 1996). The significance of Sirius Group sediments is somewhat controversial and concerns the validity of using Pliocene marine diatoms in determining age. The presence of Pliocene-age marine diatoms in the Sirius Group sparked debate over major deglaciation of the East Antarctic Ice (EAIS) sheet during the Pliocene of up to $40 \mathrm{~m}$ sea-level equivalent (Webb et al., 1984), and contradicted the established theory of a stable EAIS persisting since midMiocene times. Geomorphic evidence arguing for prolonged cold conditions in southern Victoria Land for the past 15 Ma (Marchant et al., 1996), and extremely slow landscape evolution in the Dry Valleys (Denton et al., 1993), is inconsistent with the idea of a dynamic Pliocene EAIS. However, it has been argued in the past that the diatoms were eroded from marine sediments in the East Antarctic interior, and subsequently represent an inland sea and an extreme reduction in ice volume under a global climate that was up to $3{ }^{\circ} \mathrm{C}$ warmer than present (Harwood, 1983; Webb et al., 1984; Webb and Hardwood, 1991). This method of glacial transport also conflicts with glaciological evidence from Mount Fleming that suggests the Sirius Group at that location was deposited by alpine glaciers and not a largescale advance of the EAIS (Stroeven and Prentice, 1997). An alternative explanation put forward in a more recent study attributes the source of the diatoms to atmospheric contamination and concludes that the inferred extensive collapse of the EAIS during the Pliocene was unlikely (McKay et al., 2008; Scherer et al., 2016). A more recent evaluation of the evidence by Barrett (2012) including ice sheet modelling (Pollard \& DeConto, 2009; Pollard et al., 2014) constrained by geological drilling in the Ross Sea (Naish et al., 2009) and off Wilkes Land (Cook et al., 2013; Patterson et al., 2014) and reconciled with evidence for cold arid conditions in the mountains, suggests that retreat of the West Antarctic Ice sheet and some of the subglacial basins of the East Antarctic ice sheet equivalent to $13 \mathrm{~m}$ global sea-level rise occurred in the warm midPliocene. A Pliocene age for the Sirius Group fossiliferous sediments still remains highly contentious, with the weight of evidence implying the deposits are older, perhaps OligoceneMiocene.

Despite offering up a glimpse of some of the past glacial and climatic conditions that have operated in McMurdo Sound (e.g. Speden, 1962; Mercer, 1968, 1972; Vella, 1969; Mayewski, 1975; Eggers, 1979; Denton et al., 1984 Webb et al., 1984; Webb and Hardwood, 1991), and providing some insight into the different kinds of marine fauna that have inhabited the Ross Sea region (Buckeridge, 1989), these outcrops of fossil-bearing sedimentary sequences are sporadic and temporally inconsistent across McMurdo Sound, as well as highly susceptible to erosion and remobilisation with much of Antarctica's geology hidden away or removed 
beneath extensive volumes of ice. The scattered nature of these relict glacial landforms meant that Antarctica's ice sheet history continued to remain largely elusive for the best part of the $20^{\text {th }}$ Century. Offshore marine sedimentation, on the other hand, is more constant and provides more continuous records of environmental changes such as ocean temperature, land temperature, and glacial extent, in response to shifts in the local and global climate regime. Consequently, a substantial amount of what is presently known about the behaviour of the West Antarctic Ice Sheet and its response to past warmth in Southern McMurdo Sound has come from the recovery sediment cores over the last 45 years.

\subsection{Global records of climate and sea-level change during the Pliocene-Pleistocene}

Understanding how the Earth system will respond long-term to changes in atmospheric composition and various external forcings (e.g. solar, and/or orbital) is largely dependent on the information stored in paleoclimate archives and geological proxies (IPCC, 2013). However, factors such as tectonics and biological systems in the carbon cycle (e.g. Zachos et al., 2008) can complicate the relationship between increased amounts of atmospheric $\mathrm{CO}_{2}$ and global warmth. Throughout the past $65 \mathrm{Ma}$, the natural state of the climate has repeatedly shifted towards warmer-than-present intervals which are associated with atmospheric $\mathrm{CO}_{2}$ levels higher than pre-industrial conditions (e.g. Pagani et al., 2010; Seki et al., 2010; Bartoli et al., 2011). These warm periods provide an opportunity to investigate climate sensitivities and better asses how the Earth system behaves in response to increased global temperatures and elevated atmospheric $\mathrm{CO}_{2}$. The Pliocene (5.3-.2.6 Ma) is characterised by global average temperatures up to $3^{\circ} \mathrm{C}$ warmer than present and represents the last point in time that atmospheric carbon dioxide concentrations reached 450 ppm (Crowley et al., 1991; Haywood and Valdes, 2004; Hill et al., 2014). Global sea-level and climate reconstructions for this point in time provide the most accessible evaluation of the relationships between atmospheric $\mathrm{CO}_{2}$, global climate, and changes in Antarctic ice volume, under conditions comparable to projections for Earth in the coming decades to centuries (Naish and Zwartz, 2012; Dowsett et al., 2012). 


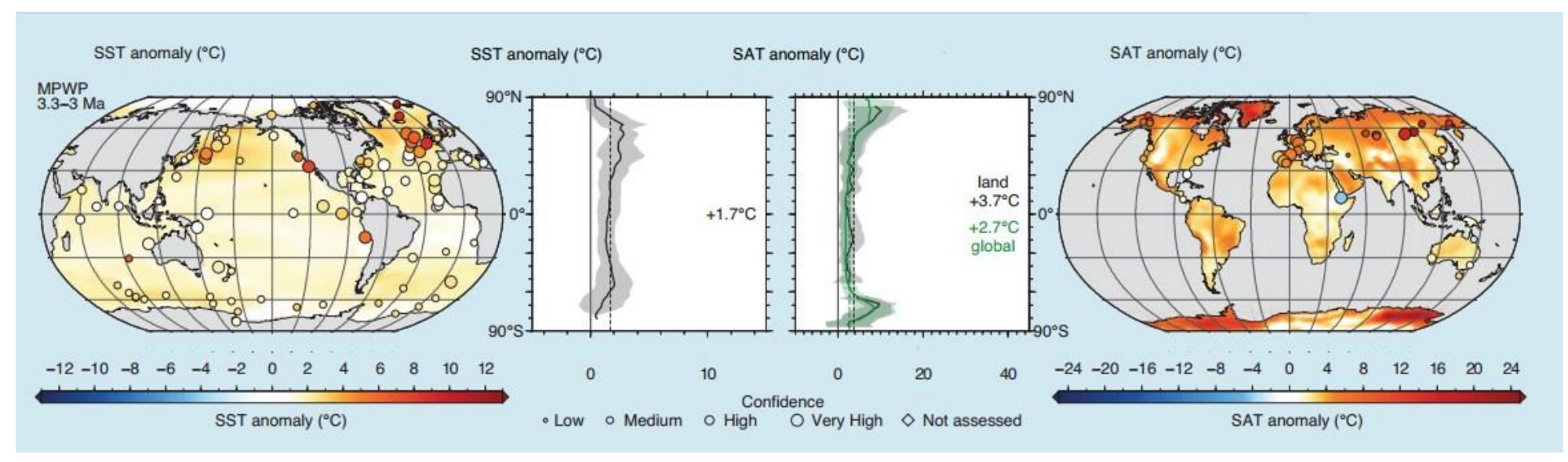

Figure 2.7: Comparison of data and multi-model mean (MMM) simulations for the Mid-Pliocene Warm Period (MPWP) showing warmer-than-present sea surface temperature (SST) anomalies, zonally averaged SST anomalies, zonally averaged global (green) and land (grey) surface air temperature (SAT) anomalies, and land SAT anomalies (IPCC, 2013).

General circulation model (GCM) results indicate that Pliocene oceans were warmer both at the surface and at depth, and were dominated by weakened meridional temperature gradients, weakened sea surface temperature gradients, and a reduction in the Pacific Ocean thermocline gradient along the equator (Fig. 2.7) (Ravelo and Andreasen, 2000; Fedorov et al., 2006; Ravelo et al., 2006; Herbert et al., 2010). Monsoon systems, including the East Asian Summer Monsoon, were likely enhanced during this time, and reconstructions of Pliocene vegetation suggest tundra was replaced by boreal forests while the extent of arid deserts diminished across the globe (Haywood et al., 2000; Salzmann et al., 2008; Brierley et al., 2009; Lunt et al., 2012). Global records of sea-level change during the Plio-Pleistocene have been obtained from a number of different far-field sources with each method accompanied by various limitations. The sea-level record preserved in submerged coral atolls, for example, provides precise waterdepth changes (e.g. Wardlaw and Quinn, 1991), but challenges arise when it comes to dating and estimating subsidence rates. A record of global sea-level change from oxygen isotope variations in benthic foraminiferal 'tests' implies moderate fluctuations in global ice volume paced by the 41 kyr obliquity cycle (Lisiecki and Raymo, 2005), but results are restricted by the ability to separate $\delta^{18} \mathrm{O}_{\text {seawater }}$ changes in response to fluctuations in ice volume from changes in deep water temperatures (Miller et al., 2012). $\mathrm{Mg} / \mathrm{Ca}$ analysis has the potential to isolate $\delta^{18} \mathrm{O}_{\text {seawater }}$ when combined with oxygen isotope data, but species calibrations and carbonate ion effects present large uncertainties (e.g. Lear et al., 2004). 
An alternative technique for estimating global sea-level change during the Pliocene-Pleistocene is to progressively remove the effects of compaction, loading, and thermal subsidence, recorded in far-field passive continental margin sequences (Miller et al., 2005). Although unable to account for the effects of tectonism and glacioisostatic adjustment, this method of backstripping has been applied to drillcore sediments from New Zealand's Whanganui Basin, producing relatively precise estimates of peak Pliocene eustatic sea level (Miller et al., 2012). The Plio-Pleistocene Whanganui Basin contains one of the most complete and largely undeformed shallow marine records with sedimentary facies and fossil faunas comparable to modern-day New Zealand coast and shelf environments (Naish, 1997; Naish and Wilson, 2009). Sedimentation has kept pace with subsidence for much of the basin's history resulting in roughly $5 \mathrm{~km}$ of basin fill. Gentle upwarping along the eastern margin of the basin has exposed $\sim 1500 \mathrm{~m}$ of Plio-Pleistocene sediments in the Rangitikei Valley that represent 58 individual glacial/interglacial depositional sequences, corresponding to oxygen isotope stages 5 through to MG 6 (Abbott and Carter, 1994; Naish and Kamp, 1997a; Naish et al., 1998; Carter and Naish, 1998). Sediments have been correlated to $41 \mathrm{kyr}$ and $100 \mathrm{kyr}$ astronomical cycles reflected in global benthic foraminiferal oxygen isotope records (e.g. Lisiecki and

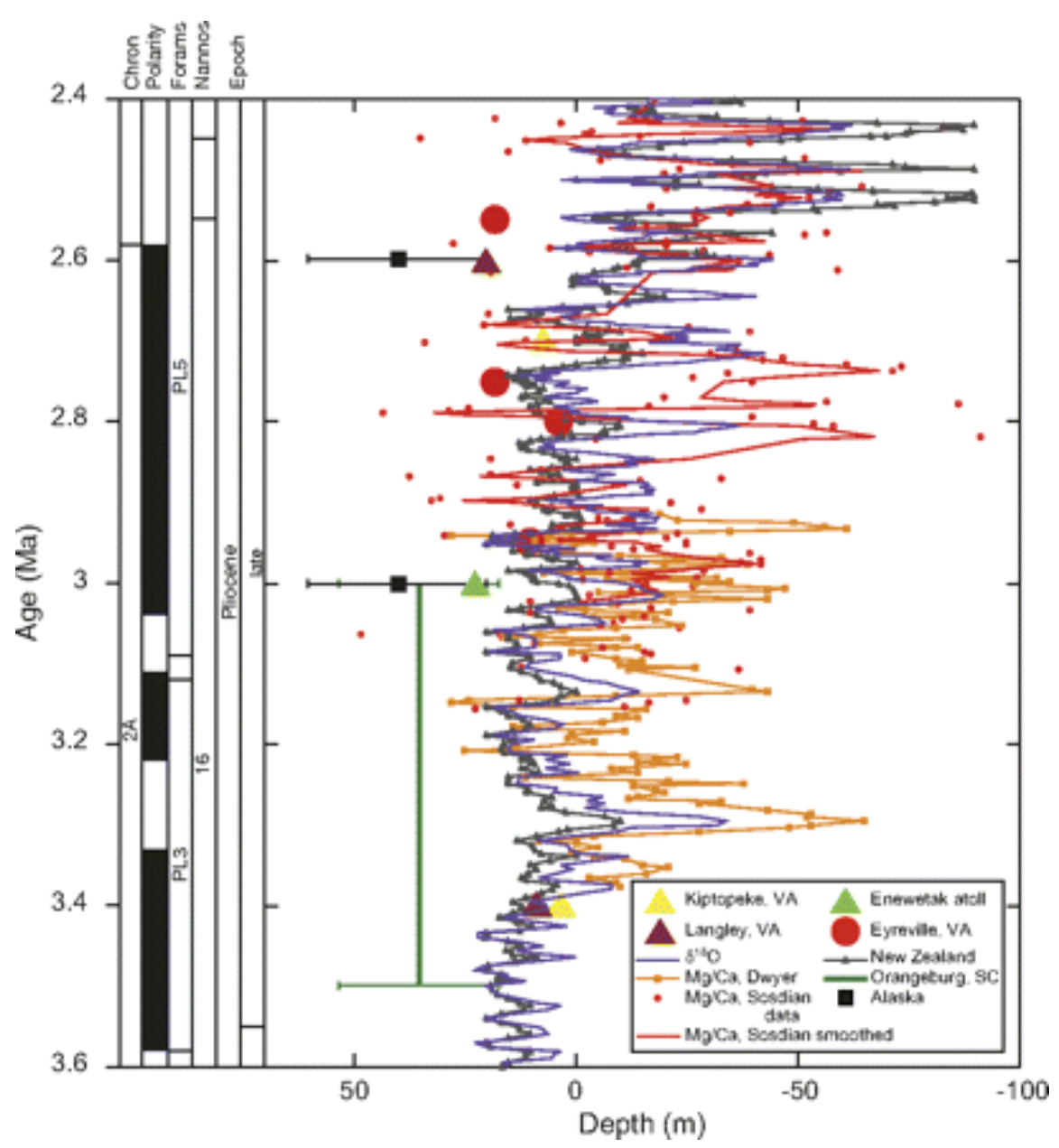

Raymo, 2005). Water depth estimates based on changes in sediment texture and benthic foraminiferal biofacies indicate deposition in neritic environments, and suggest a peak eustatic sea-level of $15-20 \mathrm{~m}$

Figure 2.8: Comparison of late Pliocene sealevel estimates from Miller et al., (2012). $\delta^{18} \mathrm{O}$ has been scaled to sea level using assumptions in Miller et al., (2012). $\mathrm{Mg} / \mathrm{Ca}$ estimates (Sosdian and Rosenthal, 2009; Dwyer and Chandler, 2009); Enewetak Atoll (Wardlaw and Quinn, 1991; Eyreville, VA (Miller et al., 2012); Kiptopeke and Langley, VA (Hayden et al., 2008); New Zealand (Naish, 1997; Naish and Wilson, 2009; Miller et al., 2012); Orangeburg scarp (Dowsett and Cronin. 1990; Alaskan terraces (Brigham-Grette and Carter, 1992). Error estimate for uplift of Orangeburg scarp shown in green error bars (Miller et al., 2012). 
above present-day heights for the interval 3.2-2.7 Ma (Fig. 2.8) (Miller et al., 2012).

Similar estimates of Pliocene global mean sea-level have also been derived by backstripping of sediments cored from the Late Eocene Chesapeake Bay impact structure in Eyreville, Virginia (Fig. 2.8). Again, variations in water depth are based on changes in lithofacies and benthic foraminiferal assemblages, and provides eustatic amplitude estimates with an error of \pm 10 -15 m. These far-field sea-level estimates rely on $7 \mathrm{~m}$ sea-level equivalent being lost from northern hemisphere ice, as well as $5 \mathrm{~m}$ from the West Antarctic Ice Sheet where it is grounded above sea level (Miller et al., 2012). The remaining $~ 10 \mathrm{~m}$ of sea-level rise is attributed to peripheral melting of the relatively stable EAIS reducing it to roughly $80 \%$ of its modern volume. Minimal loss of the EAIS during the Pliocene favours the stability hypothesis (e.g. Denton et al., 1993; Marchant et al., 1993; Kennett and Hodell, 1995; Marchant et al., 1996), and is inconsistent with arguments put forward by the "dynamicists" school which calls for extreme melting of the EAIS to two-thirds of its current size (Harwood, 1983; Webb et al., 1984; Webb and Hardwood, 1991). Such an estimate of Pliocene ice mass loss from Antarctica, and associated rise in eustatic sea-level, is in accord with modelled results capable of simulating coupled climate and grounded ice sheet dynamics (Fig. 2.9) (Pollard and DeConto, 2009; DeConto and Pollard, 2016). Assuming a regional climate model climatology of $400 \mathrm{ppm} \mathrm{CO}_{2}$ and $5^{\circ} \mathrm{C}$ ocean warming consistent with mid-Pliocene warmth, Pliocene simulations suggest an $\sim 11 \mathrm{~m}$ contribution from Antarctica initiated by meltwater-induced hydrofracturing of ice

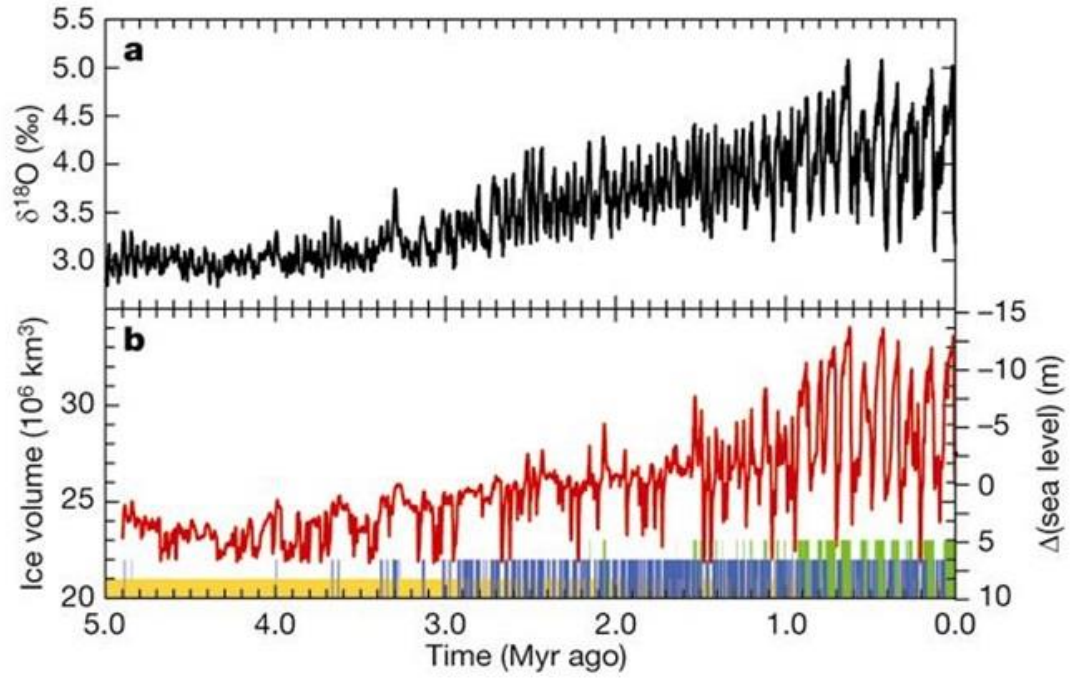
shelves, which in turn triggers marine ice sheet instability and retreat deep into WAIS and EAIS marine basins (DeConto and Pollard, 2016).

Figure 2.9: 5 myr simulation of ice volume through to the Pliocene to present. The longterm forcing trend of each forcing mechanism is parameterised predominantly as a function of the benthic $\delta^{18} \mathrm{O}$ record (DeConto and Pollard. 2016). 
Investigating warm "super-interglacials" of the Quaternary (Marine Isotope Stages MIS 31, 11, and 5e) also provides an opportunity to assess the stability of Antarctic ice sheets. Understanding the response of Antarctic ice during these "extreme" interglacial intervals is fundamental for reconstructing the Earth system processes needed to make accurate predictions about future climate responses (Pollard and DeConto, 2009; Raymo and Mitrovica, 2012; DeConto and Pollard, 2016). With a timespan of $\sim 19 \mathrm{kyr}$, MIS 31 (1.08-1.06 Ma) exists as the last interglacial of the obliquity-paced climate regime, and includes the "Mid-Pleistocene Transition" to 100 ka dominance (Flores et al., 2007). Orbital parameters for MIS 31 (Laskar et al., 1993; Laskar et al., 2004) indicate that this paleoclimate episode recorded the highest high-latitude insolation values of the past $1 \mathrm{myr}$, raising sea surface temperatures around Antarctica by up to $5^{\circ} \mathrm{C}$ and ultimately leading to the collapse of the WAIS in places where it is grounded below sea level (Pollard and DeConto, 2009). Analysis of deep sea sediments deposited in the Atlantic sector of the Antarctic region provides information on previous displacements of the Polar Front Zone. The relationship between changes in sea-ice cover, frontal systems, and water masses, can be explained by identifying intervals of coccolithophore-rich sediment in a sector where today autotrophic planktonic coccolithophores

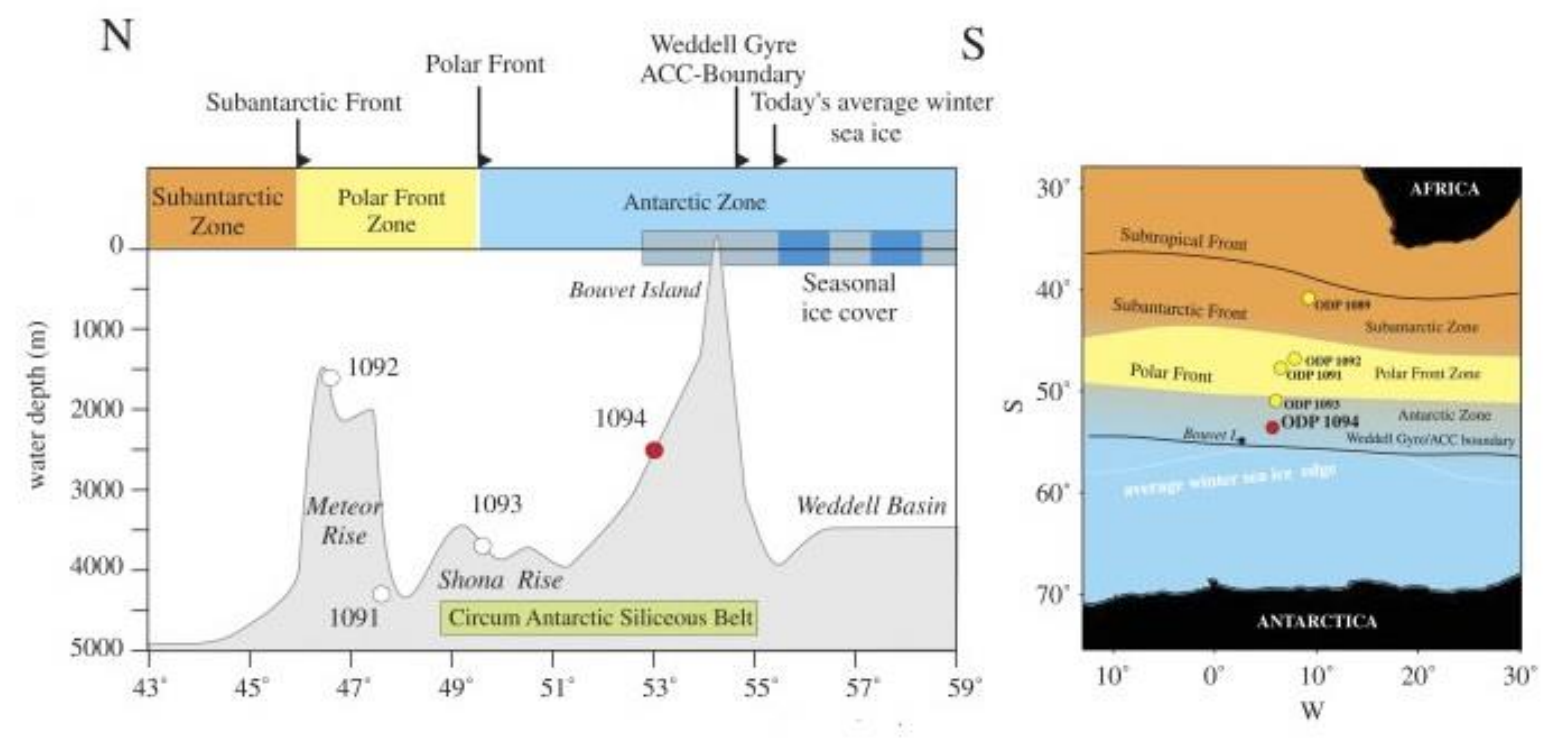

Figure 2.10: Present-day oceanographic configuration of the Atlantic Sector of the Antarctic region. Sedimentation at IODP Site 1094 is today dominated by silica-rich episodes that correspond with intervals V and I (Flores and Sierro, 2007).

are almost absent (Fig. 2.10) (Flores and Sierro, 2007). As coccolithophore assemblages are sensitive to environmental variables such as temperature, available nutrients, and salinity 
(McIntyre, 1967; Thierstein and Young, 2004), variations in $\mathrm{CaCO}_{3}$ content may denote extreme fluctuations in past climate and surface oceanography (Flores and Sierro, 2007).

Ocean Drilling Program Site 1094 is located below the Polar Front and is today dominated by diatoms and other siliceous planktonic organisms. Alternating intervals of carbonate- and silica-rich sediments within the drillcore recovered from ODP Site 1094 have been interpreted as a period of strong eccentricity and high amplitude in the insolation record (Flores and Sierro, 2007). Five intervals are distinguished based on coccolithophore assemblage and abundances which are thought to reflect the beginning and end of a warm pulse (Fig. 2.11) (Flores and Sierro, 2007). Interval $\mathrm{V}$ is the oldest and records an abundance of coccolithophore assemblages characteristic of the Polar Front Zone but with a dominance of siliceous microorganisms (Flores and Sierro, 2007). An exceptional peak in $\mathrm{CaCO}_{3}$ content during interval IV signifies maximum abundance of coccoliths with an assemblage typical of the Subantarctic Front. This southward displacement of the frontal system during what is inferred to be MIS31 is linked to an increase in sea-surface temperature and is responsible for increased productivity and species diversity (Fig. 2.12) (Flores and Sierro, 2007). Coccolithophore taxa known to occur in other environments with anomalies in salinity, i.e. related to iceberg melting (Sierro et al., 2005), or riverine discharge (Colmenero-Hidalgo et al., 2004), are also observed to increase during Interval IV. An apparent reduction in salinity at ODP Site 1094 during MIS31 is consistent with melting of the WAIS (Scherer, 1993; Flores and Sierro, 2007). A decrease in the $\delta^{18} \mathrm{O}$ signature of benthic fauna for the same interval (Fig. 11) (Lisiecki and Raymo, 2005), and a reduction in the $\delta^{13} \mathrm{C}$ of benthic fauna in the North Atlantic (e.g. Kleiven et al., 2003),
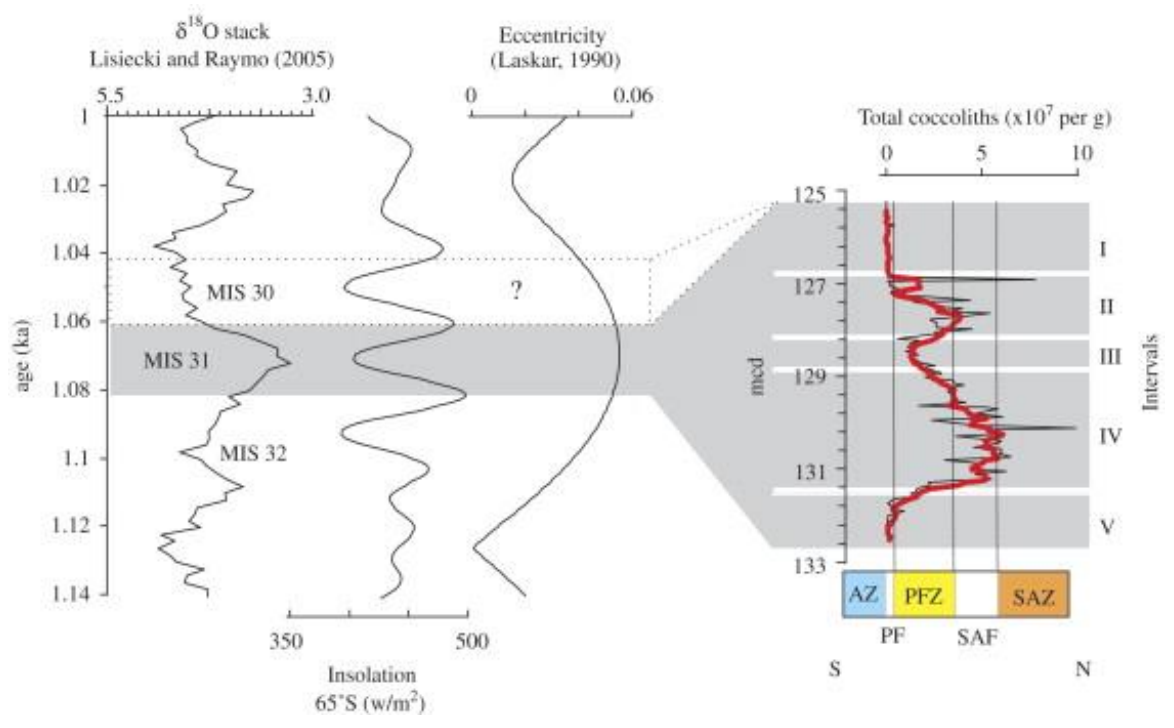

Figure 2.11: Total abundance of coccolithophores at ODP Site 1094 vs. orbital eccentricity and insolation (Laskar, 1990). The smoothed curve in total abundance of coccoliths is correlated with the main oceanographic zones and fronts in the region (Flores and Sierro, 2007). further suggest an 
increase in melt water from retreating ice, and indicates a strong inter-hemispheric response of polar environments during MIS 31 (Flores and Sierro, 2007).
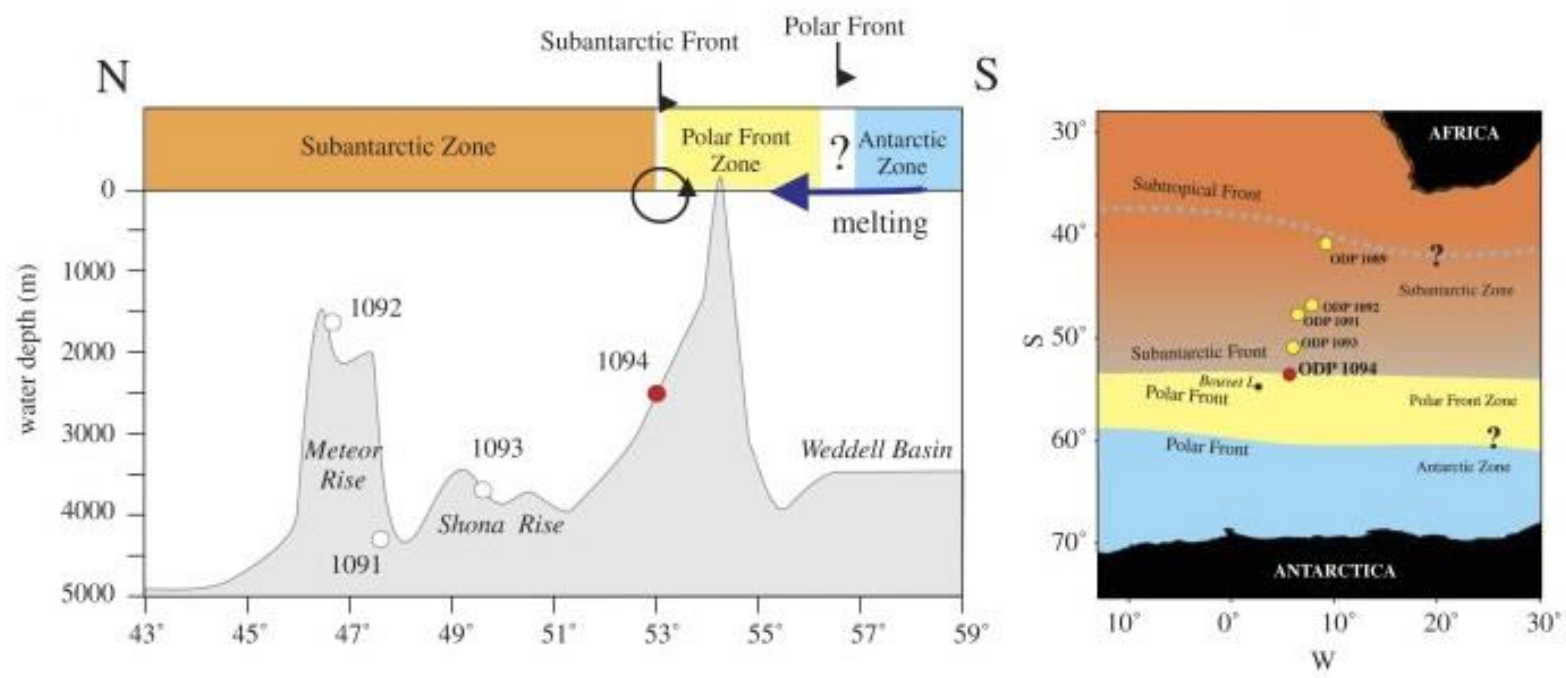

Figure 2.12: Paleoceanographic configuration of the Atlantic Sector of the Antarctic region during MIS31. Peak abundance of coccoliths indicates maximum southward displacement of the main oceanic frontal systems during Interval IV when sea surface temperatures around Antarctica were up to $5^{\circ} \mathrm{C}$ warmer. The proximity of the Subantarctic Front is associated with high productivity, as well as possible fresh-water discharges from melting continental ice (Flores and Sierro, 2007).

Marine isotope stage $11(\sim 420 \mathrm{ka})$ is another significant episode of protracted interglacial warmth in the Quaternary paleoclimate record. However, as with estimates of ice volume and associated changes in sea-level during peak Pliocene warmth, MIS 11 sea-level markers also have their limitations (Raymo and Mitrovica, 2012). Pleistocene shoreline features on the islands of Bermuda, the Bahamas, and Oahu (Hearty et al., 1999; Kindler and Hearty, 2000; Hearty, 2002a; Olson and Hearty, 2003; Hearty and Olson, 2009) indicate that sea-level was in excess of $20 \mathrm{~m}$ above present-day heights around $400 \mathrm{ka}$. Pleistocene deposits of similar height above sea-level have also been described from the coast of South Africa (Bateman et al., 2011), the Netherlands Antillean islands of Curaçao and Bonaire (Lundberg and McFarlane, 2002), and along the North Slope of Alaska (Kaugman and Brigham-Grette, 1993). For this estimate to be the case, significant melting of the EAIS would have to occur in addition to the collapse of the WAIS and Greenland Ice Sheet (GIS) (Hearty et al., 1999; Olson and Hearty, 2009; van Hengstum et al., 2009). The global benthic $\delta^{18} \mathrm{O}$ record, however, does not support a MIS 11 highstand of $+20 \mathrm{~m}$ (Poore and Dowsett, 2001; McManus et al., 2003). By applying a range of tectonic uplift corrections based on assumed elevations of MIS 5e sea-level indicators 
(Bowen, 2010), comparison of these and other MIS 11 sea-level records worldwide provide an estimated peak MIS 11 highstand of 6-9 m above the modern-day value (Raymo and Mitrovica, 2012). The upper bounds of this estimate suggest complete collapse of the WAIS and up to 7 m sea-level equivalent of melt from the GIS during MIS 11 (Bamber et al., 2009; Raymo and Mitrovica, 2012), which is a finding consistent with marine $\delta^{18} \mathrm{O}$ anomalies (McManus et al., 2003).

Emergent shoreline deposits (e.g. Blanchon et al., 2009; Thompson et al., 2011; Dutton and Lambeck, 2012) and the global benthic $\delta^{18} \mathrm{O}$ record (Siddall et al., 2003; Rohling et al., 2008; Grant et al., 2012) have also been used to reconstruct changes in ice volume and associated rise in sea-level during the peak of the Last Interglacial (LIG) MIS 5e ( 125 ka). Emergent shoreline deposits on tectonically active coasts have the potential to constrain the initiation and duration of the LIG if vertical uplift rates are known independently (Stirling et al., 1998; Thompson and Goldstein, 2005). However, these estimates of peak LIG sea-level are reliant on being able to isolate the geophysical processes, i.e. glacial isostatic adjustment, subsidence, and uplift, that can affect the elevation of sea level indicators. Evidence from two tectonically stable areas, Australia and the Seychelles islands, has instead been used make inferences about the maximum height of sea level during the LIG (Dutton and Lambeck, 2012). Both of these locations are far-field from the former ice margins and as a result isostatic signals are less sensitive to the parameters defining rheology of the Earth and the glacial ice sheets (Dutton and Lambeck, 2012). The highest LIG reef elevations along the western coastline of Australia are $+3.5 \mathrm{~m}$, which is equal to $+5.5 \mathrm{~m}$ of sea-level rise relative to present when taking into consideration possible reef erosion (Fig. 2.13) (Dutton and Lambeck, 2012). LIG coral reefs at the Seychelles islands typically range from 0-6 m (Dutton and Lambeck, 2012), but they have been found to occur as high as $9 \mathrm{~m}$ (Israelson and Wohlfarth, 1999). Together these results imply a LIG sea-level peak of less than $10 \mathrm{~m}$ above present, but upwards of $5 \mathrm{~m}$ above current levels (Dutton and Lambeck, 2012; IPCC, 2013). 


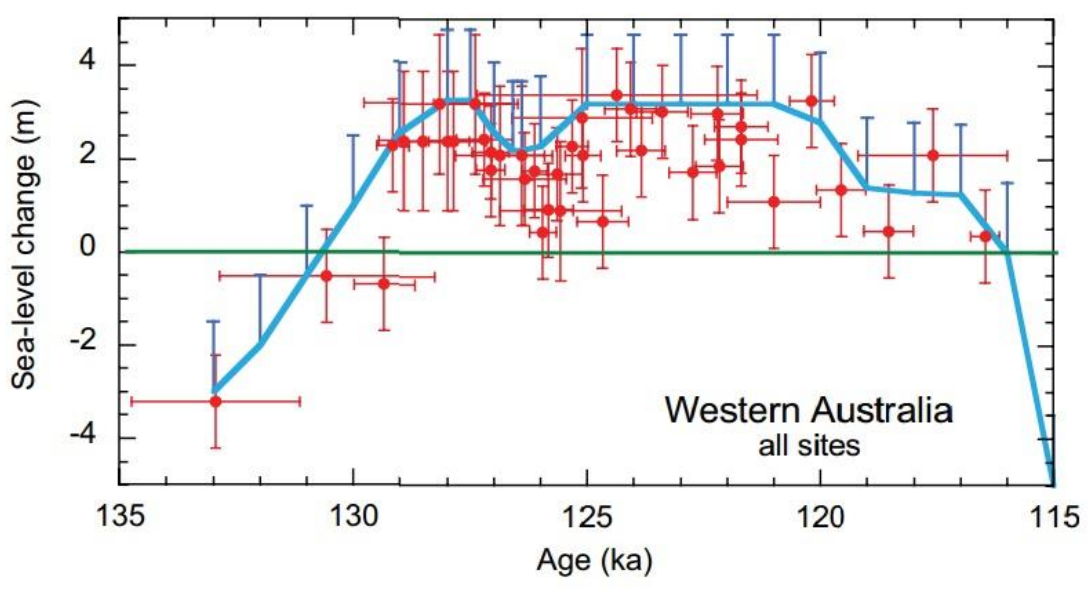

Figure 2.13: Reconstructions of LIG relative sea level along the coast of Western Australia based on in-situ coral elevations (red) that pass diagenetic screening. Error bars correspond to two standard deviation uncertainties (Dutton and Lambeck, 2012; IPCC, 2013).

A probabilistic assessment of LIG sea level by Kopp et al. $(2009 ; 2013)$ provides an estimate of LIG Global Mean Sea Level (GMSL) using a geographic database of widely dispersed sea level indicators (Fig. 2.14) (Kopp et al., 2013). Taking into account uncertainties in geochronology, as well as the effects of GIA, subsidence, and regional tectonic uplift, Kopp et al. (2013) estimate a maximum sea-level rise of 6-8 $\mathrm{m}$ above present-day levels, but not in excess of $+9.4 \mathrm{~m}$. Rates of sea level rise for the LIG vary between 1.1 and $2.6 \mathrm{~m}$ per century according to the foraminiferal $\delta^{18} \mathrm{O}$ record from the Red Sea (Rohling et al., 2008). However, the chronology for the original Red Sea record is based on a shorter LIG duration of 124-119 ka (Thompson and Goldstein, 2005). Coral data from Stirling et al. (1998) suggests a longer LIG duration of $130-116 \mathrm{ka}$ and reduces the rate of sea-level rise to $0.4-0.9 \mathrm{~m}$ per century. This finding is consistent with a revised chronology for the Red Sea sea-level record which indicates sea level rise rates of up to 0.7 m per century during the LIG (Grant et al., 2012).'

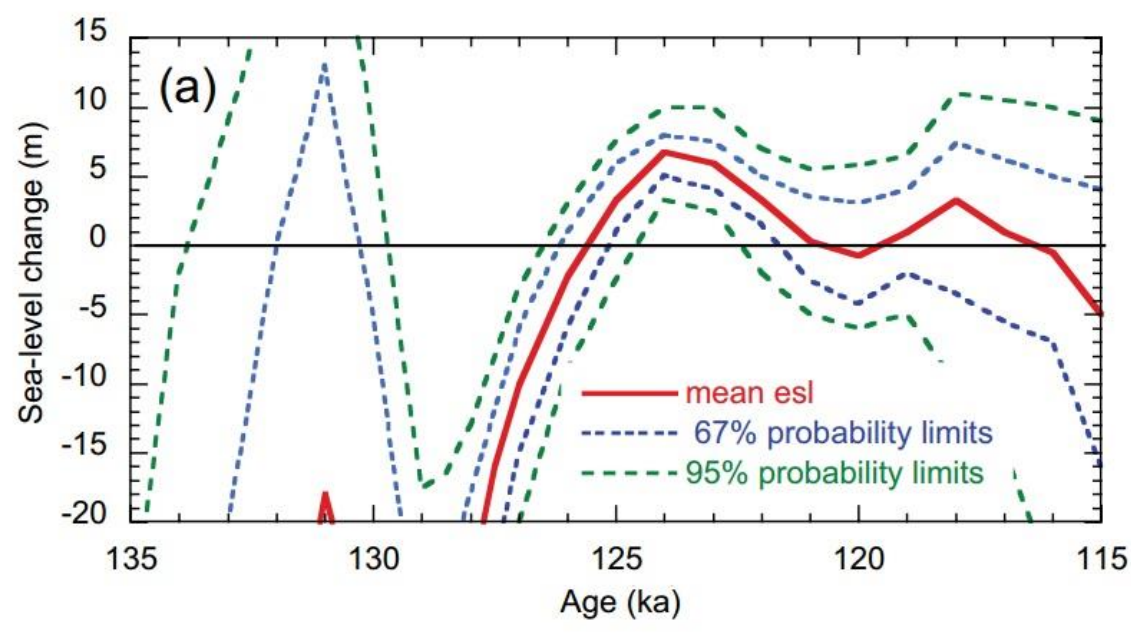

Figure 2.14: Proxy-derived estimate of GMSL. Kopp et al. (2013) estimate a maximum sea-level rise of 6-8 $\mathrm{m}$ above present-day levels based on a geographic database of widely dispersed sea level indicators (Kopp et al., 2013; IPCC, 2013). 
The WAIS, marine-based portions of the EAIS, and the GIS, are inferred to be the principle source of LIG meltwater. However, the precise contribution of Antarctic ice volume to LIG sea level has not been fully substantiated by observational and model evidence (IPCC, 2013). Using the benthic $\delta^{18} \mathrm{O}$ record for the past $5 \mathrm{Ma}$, an earlier model of WAIS glacial-interglacial variability by Pollard and DeConto (2009) produced very little difference in Antarctic ice volume between the LIG and present (Pollard and DeConto, 2009; IPCC, 2013). Sedimentological evidence from the southeastern and northwestern sectors of the Ross Ice Shelf imply that open-water conditions persisted at some time both during the last $1 \mathrm{Ma}$ (Scherer et al., 1998; McKay et al., 2011; Vaughan et al., 2011), and within the last 250,000 years during the LIG (McKay et al., 2012a). Ice layers in Greenland ice cores, on the other hand, suggest that southern Greenland was not ice-free during the LIG (Colville et al., 2011). Data from the North Greenland Eemian Ice Drilling (NEEM) project indicate the presence of ice throughout the LIG, possibly decreasing in elevation by up to $350 \mathrm{~m}$ between 128 and 122 ka (Dahl-Jensen et al., 2013). These elevation changes observed in the ice core record are reflected in GIS simulations that show a contribution of 1.4-4.3 m sea level equivalent (IPCC, 2013).

Though there are few direct observational constraints on the location of ice margins during the LIG, a significant reduction in Antarctic ice volume is required given the inferred contribution from the GIS to GMSL (IPCC, 2013). Previous Antarctic ice sheet simulations that account for Marine Ice Sheet Instability dynamics and migrating grounding lines, however, have been incapable of applying realistic boundary conditions and as a result have underestimated the contribution of Antarctic ice volume to GMSL during the LIG (DeConto and Pollard, 2016). Unlike the warm mid-Pliocene, LIG summer air temperatures were cooler (Capron et al., 2014), reducing the potential for surface meltwater production and instead pointing to ocean temperatures as the main driving force behind LIG ice retreat (Overpeck et al., 2006; Duplessy et al., 2007). To simulate LIG ice sheets, DeConto and Pollard (2016) employ a coupled ice model/high-resolution atmospheric regional climate model that is able to capture the orographic details of ice shelves and ice sheet margins (Fig. 15). As expected with the cooler orbit of the Earth $128 \mathrm{kyr}$ ago, summer air temperatures remain below freezing with little to no surface melt. Instead, ocean warming of $>4^{\circ} \mathrm{C}$ is needed to raise GMSL by $3.5 \mathrm{~m}$ and initiate WAIS retreat at $128 \mathrm{ka}$, which occurs once an ocean-melt threshold in the stability of the Thwaites grounding line has been reached (DeConto and Pollard, 2016). The GMSL contribution increases further to $>6.5 \mathrm{~m}$ when the additional influence of circum-Antarctic 
ocean warming is taken into consideration (DeConto and Pollard, 2016). The ocean-driven continental warming reproduced by DeConto and Pollard (2016) (Fig, 15) is consistent with ice core records (Capron et al., 2014) and gives weight to the notion that the timing of ice-sheet retreat during the LIG was controlled by ocean warming (Overpeck et al., 2006; Duplessy et al., 2007).
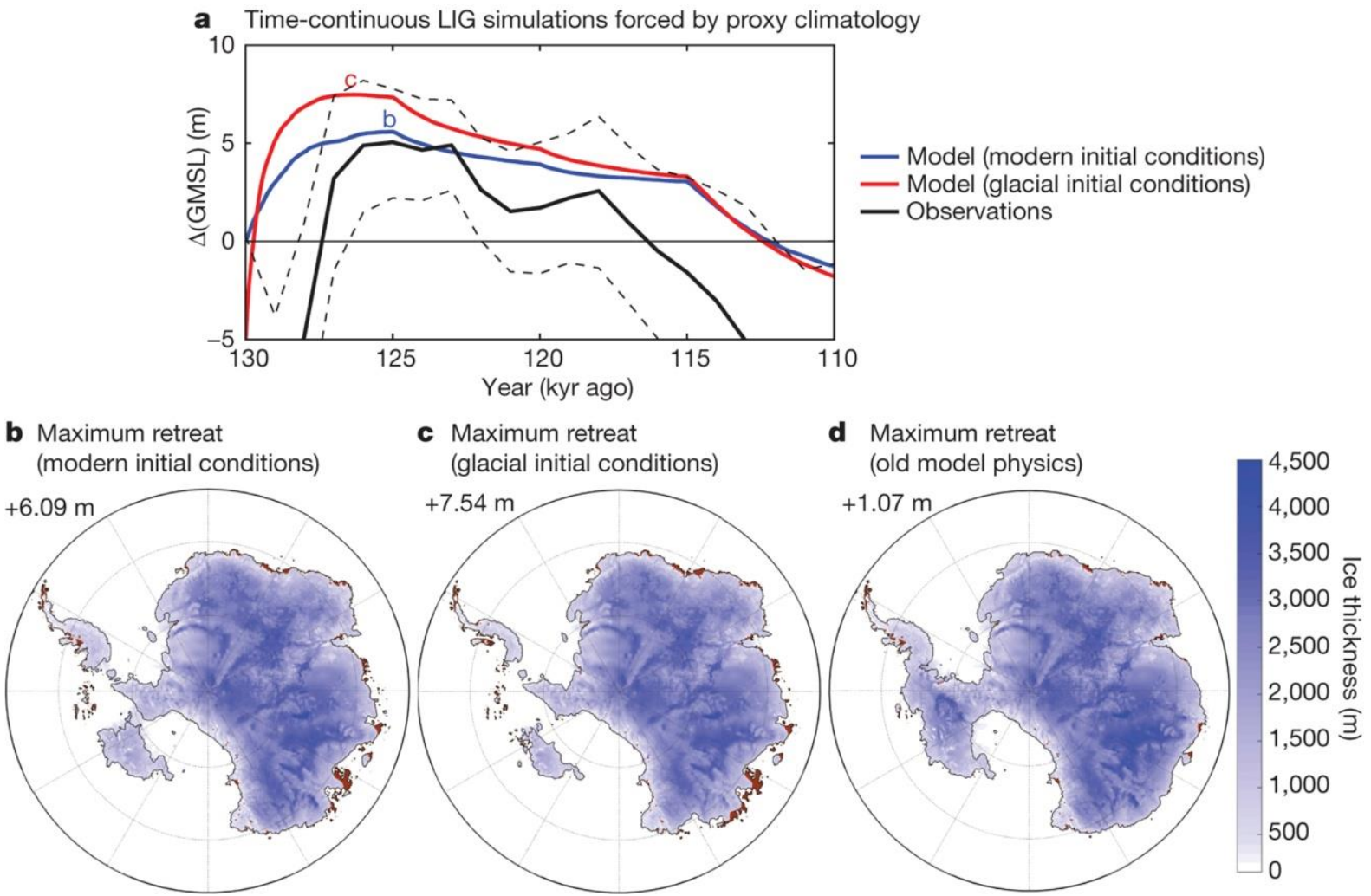

Figure 2.15: a) Change in GMSL in LIG simulations starting at $130 \mathrm{kyr}$ ago and initialised with a modern ice sheet (blue) or a bigger LGM ice sheet representing glacial conditions at the onset of the LIG (red). A probabilistic reconstruction of Antarctica's contribution to GMSL is shown in black with uncertainties (16th and 84th percentiles) as dashed lines. b) and c) show ice-sheet thickness at the time of maximum retreat using modern initial conditions (b) and using glacial initial conditions (c). Ice-free land surfaces are brown. The bigger sea-level response when initialised with the 'glacial' ice sheet is caused by deeper bed elevations and the $~ 3,000$-yr lagged bedrock response to ice retreat (Huybrechts, 1992), which enhances bathymetrically sensitive Marine Ice Sheet Instability dynamics. D) The same simulation as b) without the new model physics accounting for meltwater-enhanced calving or ice-cliff failure (Pollard and DeConto, 2012). GMSL contributions are shown at top left (DeConto and Pollard, 2016). 


\subsection{Antarctic geological drill core records of Neogene ice volume change in the Ross Sea.}

Major advances in understanding the timing of formation and complex history of Antarctica's continental and shelf ice were made as a result of early Deep Sea Drilling Programme campaigns to the oceanic regions circumferential to Antarctica. Sediment cores recovered by Glomar Challenger provided the first conclusive evidence of Antarctic ice calving at the coastline and transporting debris offshore by late Oligocene (Barrett, 1975a; 1975b; Hayes and Frakes, 1975), and furnished the first prolonged record of Antarctic ice-volume changes throughout the Cenozoic (Shackleton and Kennett, 1975; Kennett and Shackleton, 1976; Kennett, 1977). However, it was not possible to infer from these sediments whether or not the ice terminating at the coastline was part of extensive continental glaciation, nor could the overall breadth and magnitude of Antarctic ice be precisely estimated. As the direct influence of ice advance and retreat is most evident on-land, unlocking information of this scale is reliant on acquiring sediment cores from the Antarctic margin. The Dry Valley Drilling Project was the first of its kind in Antarctica, and combined a team of scientists from New Zealand, Japan, and the United States, with a shared desire to extend the geologic record on-land and eliminate speculation clouding Antarctica's perplexing and elusive glacial history (Smith, 1981). DVDP 15 drilled the seafloor of McMurdo Sound for the first time in 1975 targeting a 300 m-thick Cenozoic glacial sequence, but operations were abandoned at just $65 \mathrm{~m}$ after cracks appeared on sea ice that was being used as the drilling platform (Barrett and Treves, 1981).

A second hole on the floor of McMurdo Sound was proposed as part of the McMurdo Sound Sediment and Tectonic Studies drilling programme in another effort to reach the target depth of $300 \mathrm{~m}$ (Barrett and McKelvey, 1986). This second attempt in 1979 successfully recovered $227 \mathrm{~m}$ of sediment core, still short of the $300 \mathrm{~m}$ required to reach the base of the glacial strata, but results were able to complement data obtained from the nearby Dry Valley Drilling Project and help piece together the emerging glacial history of the Victoria Land Basin (Barrett, 1986; Barrett and McKelvey, 1986; Barrett et al., 1987). A further wave of drilling in McMurdo Sound came under the Cenozoic Investigations in the Western Ross Sea (CIROS) programme, which again targeted Cenozoic glacial sequences beneath the seafloor, as close to the Antarctic ice sheet as bedrock drilling allowed for at the time, with the ultimate goal of establishing a complete record of Antarctic glaciation throughout the Cenozoic (Barrett, 1989). The compiled sedimentary record significantly advanced what was then understood about the extent of continental ice on Antarctica throughout the Cenozoic, and greatly improved assumptions 
surrounding the influence Antarctic ice has on the global paleoclimate and eustatic sea level heights (Webb, 1990). The challenge for the next decade of scientific drilling was to try and comprehensively evaluate the cause and effect of glacial and interglacial episodes in Antarctica, and determine what, if any, relation did these phenomena have to the observed trends in deep sea oxygen isotope values (Webb, 1990).

The Cape Roberts Project was designed in response to these remaining unanswered questions, and, following in the footsteps of DVDP, CRP was a multinational collaboration involving scientific teams from New Zealand, Italy, USA, UK, Germany, and Australia (Barrett et al., 1995). One of the primary objectives of CRP was to try and establish if Antarctica had extensive continental ice waxing and waning prior to its widely-accepted formation at $34 \mathrm{Ma}$, and whether this growth and decay of ice produced concurrent changes in eustatic sea level heights (Barrett et al.,, 1995). Three drill sites were chosen in the southwest sector of the Ross Sea (Fig. 2.16) after seismic surveys revealed over $2000 \mathrm{~m}$ of strata older than $30 \mathrm{myr}$. The aim of the proposed overlapping drill sites was to recover a continuous $1300 \mathrm{~m}$ core, close to what was most likely the centre of Antarctica's continental glaciation, with past wells from the nearby CIROS project making it possible to trace the lateral extent of major units through the Victoria Land Basin and enable the correlation of strata (Fig. 2.16) (Barrett et al., 1995; Barrett, 2009).

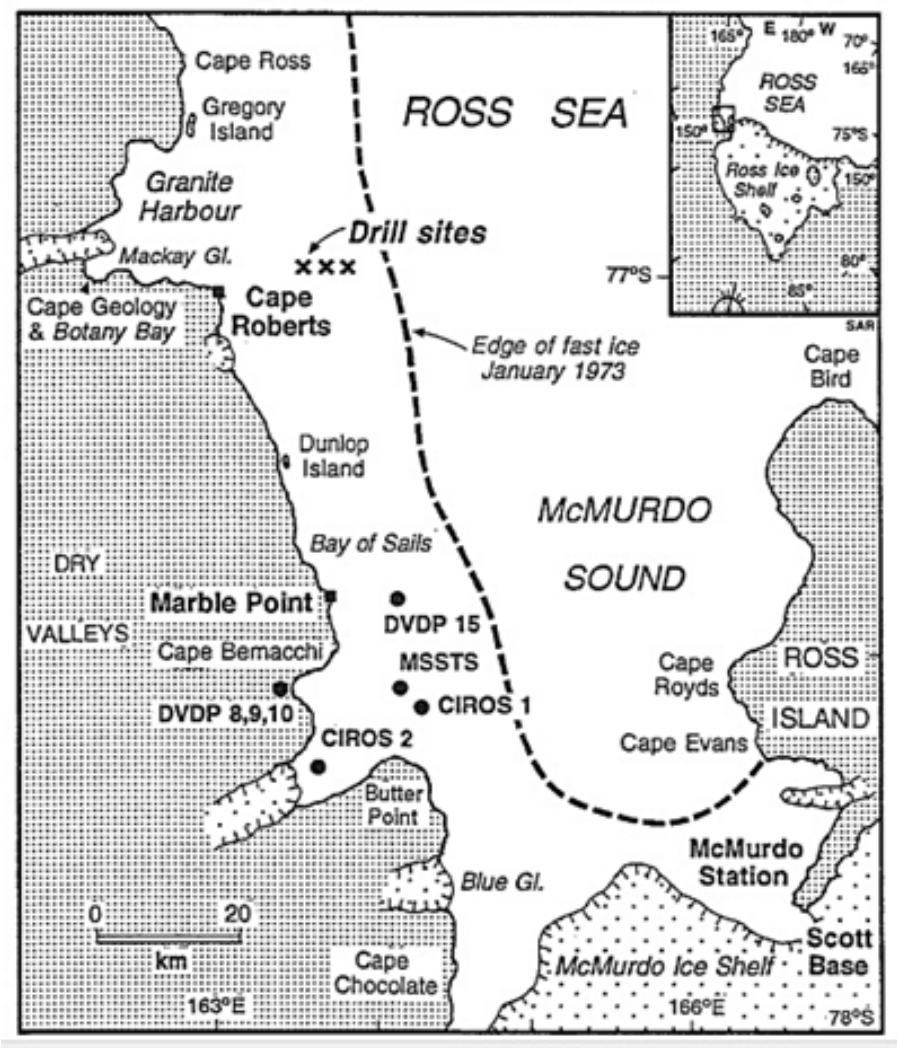

Figure 2.16: Location of the Cape Roberts Project drill sites and sites previously drilled in the McMurdo Sound region. The aim of the proposed overlapping drill sites was to recover a continuous $1300 \mathrm{~m}$ core, close to what was most likely the centre of Antarctica's continental glaciation, with past wells from the nearby drilling projects making it possible to trace the lateral extent of major units through the Victoria Land Basin (Barrett et al., 1995). 
Previous glacimarine records recovered from on, or near, the Antarctic margin suggest that grounded ice has been a prominent feature on the continent since early Oligocene (Hayes et al., 1975; Barrett et al., 1975; Barrett et al., 1986; Barrett et al., 1989). Oxygen isotope measurements from benthic foraminifera are consistent with evidence obtained from these continental margin sequences, and display a pronounced step in $\delta^{18} \mathrm{O}$ in concert with widespread ice rafting around $35 \mathrm{Ma}$ (Shackleton and Kennett, 1976; Zachos et al., 1992). The exact origin of the causal relationship between orbital-forcing of the Earth's climate and Antarctic ice sheet response had been contentious, until chronological data ( $\mathrm{Ar} / \mathrm{Ar}$ ages on tephra, biostratigraphy, $\mathrm{Sr} / \mathrm{Sr}$ dating) allowed the duration of a series of glacial-interglacial sedimentary sequences to be constrained at the Oligocene-Miocene boundary. This showed for the first time that the Antarctic ice sheet responded dynamically to orbital forcing, during a time when atmospheric $\mathrm{CO}_{2}$ was significantly higher than today (Naish et al., 2001).

One of the primary objectives of the Cape Roberts Project was to try and obtain a continuous history of changes in climate and sea level preserved in the sedimentary record on the Antarctic margin. The retrieval of CRP-2/2A and CRP-3 largely fulfilled the climate aspects of this multinational drilling programme by providing ca. $1200 \mathrm{~m}$ of pre-Pliocene sediment that represent deposition in various glacimarine conditions (Barrett et al., 2000). The vertical succession of facies contained in Cape Roberts drillcores is inferred to be a reflection of oscillations in the ice margin across the Western Ross Sea shelf and associated changes in water depth. These changes in depositional environment observed throughout CRP stratigraphic sequences provide direct evidence of Oligocene-Miocene glacial advance and retreat taking place at Milankovitch frequencies. The Cape Roberts Project was successful in recovering 95\% of the entire cored interval and established a new record in bedrock drilling in Antarctica, however, with just $72 \mathrm{~m}$ of Quaternary-aged sediments described in CRP-1 a detailed record of recent climate change in Antarctica was out of reach (Barrett et al., 2000).

The Antarctic Geological Drilling (ANDRILL) initiative was the next multinational drilling programme in Antarctica which built upon the Cape Roberts Project's method of using floating ice as a platform to drill beneath the floor of McMurdo Sound. During the austral summer of 2006-07 ANDRILL's first season of drilling got underway in Windless Bight, McMurdo Sound, situated atop $83 \mathrm{~m}$ of shelf ice and $870 \mathrm{~m}$ of water. Known as the McMurdo Ice Shelf Project, the site setting for the AND-1B drill hole was a strategic location, chosen specifically in the Ross embayment where Quaternary volcanic loading of the crust by Ross Island has created sufficient accommodation space to prevent the erosion of the sedimentary record by 
grounded ice (Fig. 2.17) (Naish et al., 2007; Denton and Hughes, 2002). Variations in the amount of local ice in this key sector of Southern McMurdo Sound are indicative of the overall West Antarctic glacial state as both are strongly influenced by changes in ocean-induced melt. Consequently, one of the primary goals in targeting this flexural moat basin was to enhance present understanding surrounding the complex behaviour of both the Ross Ice Shelf/Ice sheet and the West Antarctic Ice Sheet, as well as determine the role Antarctic ice has to play in both driving the global climate-ocean circulation system and raising global sea-levels (Naish et al., 2007).

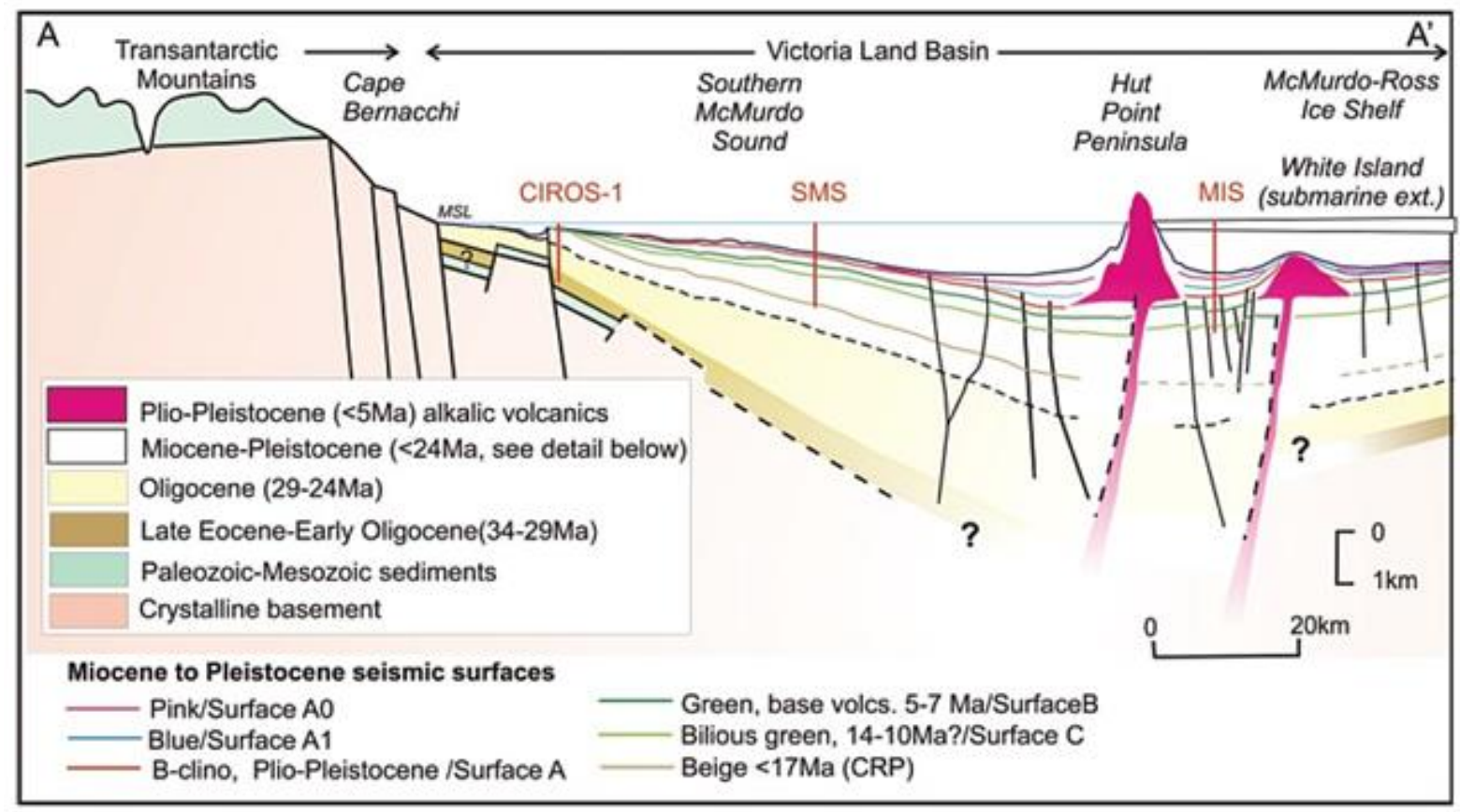

Figure 2.17: Site setting for the AND-1B MIS and AND-2A SMS drill hole. This strategic location was chosen specifically in the Ross embayment where Quaternary volcanic loading of the crust by Ross Island has created sufficient accommodation space enough to prevent the erosion of the sedimentary record by grounded ice (Naish et al., 2007)

Eight major lithostratigraphic units are defined within the AND-1B core and represent specific environments of deposition that change through time in response to both the thermal characteristics of the depositing ice and the proximity of the ice sheet grounding zone (Krissek et al., 2007). The changing nature of sediments and features throughout AND-1B has enabled the distinction between a cyclical succession of conditions in the Ross embayment ranging from $i$ ) coverage by a floating ice shelf comparable to present-day McMurdo Sound, ii) open ocean with little or no sea ice under interglacial conditions warmer than today, and iii) 
completely overridden by an ice sheet grounded on the seafloor during orbitally-forced glacial episodes (Fig. 2.18) (Naish et al., 2009). An extended period of open ocean deposition between 3.6 - 3.4 Ma is reflected in an 83 m-thick diatomite that lacks any sea ice-associated diatom flora; when combined with foraminiferal $\delta^{18} \mathrm{O}$ values significantly lower than any point during the Holocene, this diatomite unit reflects deglaciation of the WAIS under a climate system $2-3^{\circ} \mathrm{C}$ warmer than present, with atmospheric $\mathrm{CO}_{2}$ values in excess of 400 ppm (Naish et al., 2009).

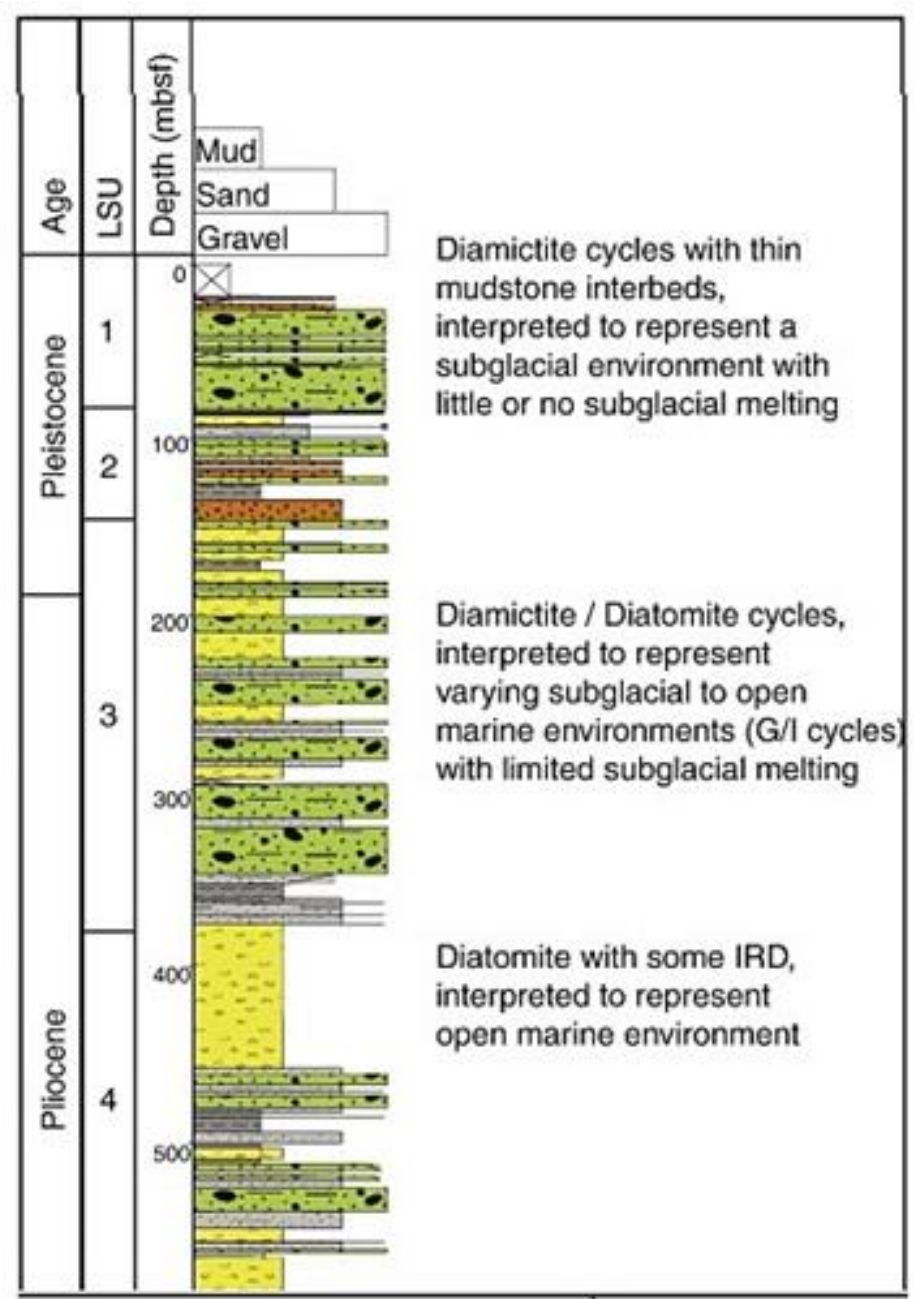

Figure 2.18: An example of the lithostratigraphic units observed throughout AND-1B. The changing nature of sediments in this drillcore is interpreted to reflect deposition across range of glacimarine environments (Naish et al., 2009).

During the austral summer of 2007-08 ANDRILL retrieved its second sediment core AND-2A from beneath Southern McMurdo Sound. The 1183 metre-long stratigraphic record obtained as part of the Southern McMurdo Sound Project is comprised of 14 lithostratigraphic units amongst which 13 recurrent lithofacies are recognised (Fielding et al., 2008). These lithofacies range once more from terrigenous clastic diamictite units deposited under subglacial conditions, through to glacimarine sandstones and fossil-bearing mudstones, and diatomites indicative of pelagic sedimentation in open marine settings. Stratigraphic sequences within 
AND-2A are bounded at the base by diamictites that represent episodes of ice advance, and are overlain terrigenous clastic facies that are characteristic of glacial retreat, marine transgression, and sea-level highstand (Fig. 2.19) (Fielding et al., 2008).

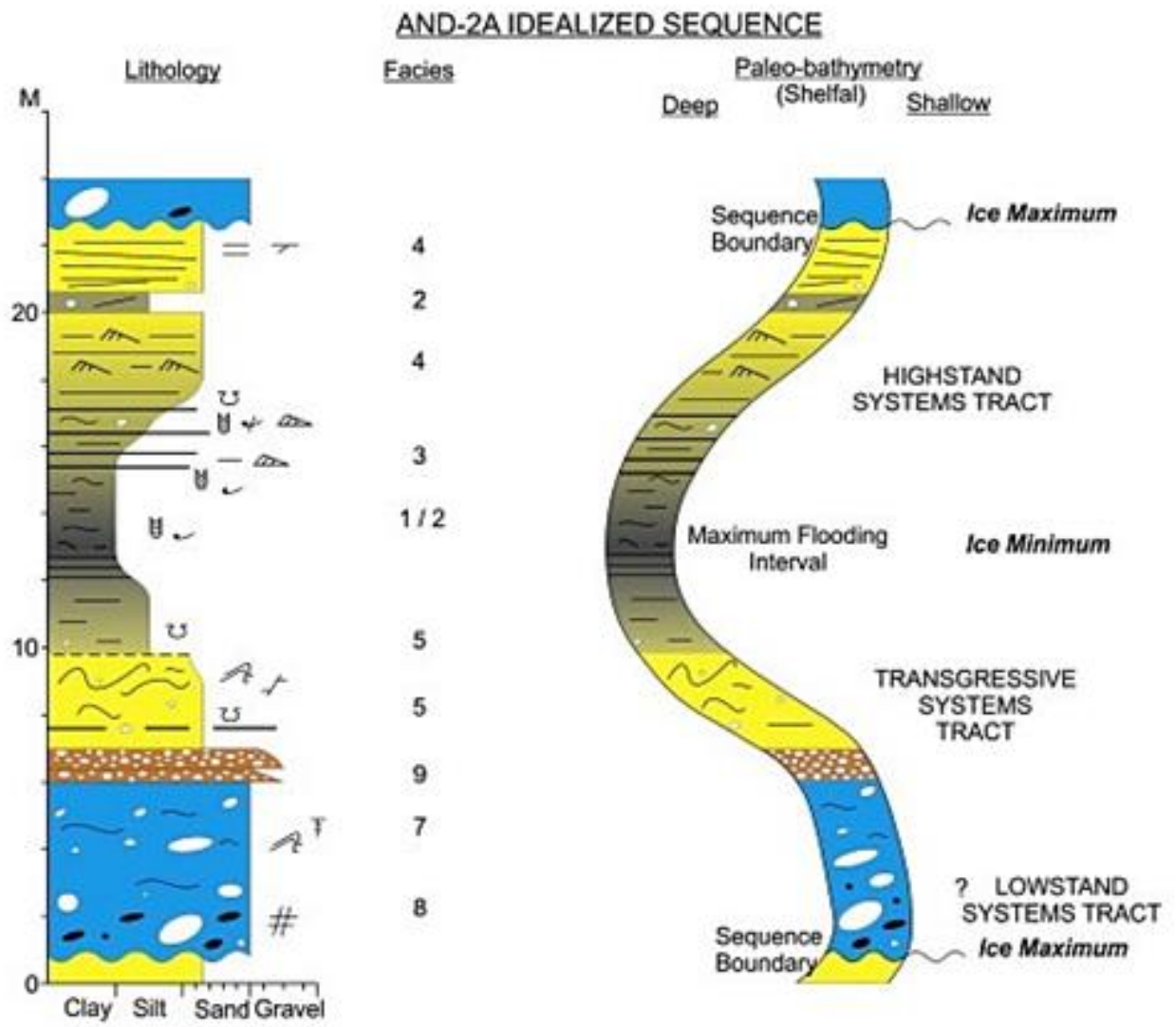

Figure 2.19: Facies stacking pattern and idealised interpretation of a complete glacimarine sequence occurring within the AND-2A sedimentary record (Fielding et al., 2011)

A total of 385 samples were collected from various intervals throughout AND-2A and examined for foraminifera. Three main foraminiferal assemblages emerged from this investigation, dominated by calcareous benthic taxa, which have provided a means of evaluating ice-proximity and paleobathymetry contained in the AND-2A sedimentary record (Patterson and Ishman, 2012). Cibicides-Cassidulinoides Assemblage is the first assemblage recognised and is primarily comprised of Cibicides spp., Cassidulinoides spp., Oolina spp., Eponides bradyi, and Ammoelphidiella sp. Assemblage two is defined by an increase in Ammoelphidiella sp. and as a result is known as the Ammoelphidiella Assemblage. Both of these assemblages are found throughout the entire AND-2A drillcore, but restricted to the uppermost middle Miocene and Pliocene record is the Ehrenbergina Assemblage which is characterised by a dominance of Ehrenbergina glabra, Globocassidulina sp., Globocassidulina 
subglossa, Cassidulina porrectus, and Angulogerina earlandi (Fig. 2.20). These taxa are important paleoenvironmental indicators of ice-edge conditions, and this third and final main assemblage is thought to record the inception of a polar regime, transitioning in the latest middle Miocene and reaching its full extent by the Pliocene (Patterson and Ishman, 2012). The first occurrence of the planktonic foraminifera Neogloboquadrina pachyderma in uppermost middle Miocene sediments of AND-2A signifies the onset of truly polar conditions in Antarctica, while the Pliocene record also contains planktonic species N. pachyderma, and Globorotalia sp., as well as reworked specimens of Antarcticella Antarctica, signifying intervals of open-water deposition with little to no summer sea ice. Epibenthic fauna found in the Cibicides-Cassidulinoides Assemblage are consistent with this finding, and are suggestive of a depositional environment during the Pliocene that was dominated by a strong glacial influence and more energetic bottom currents (Fig. 2.20) (Patterson and Ishman, 2012).

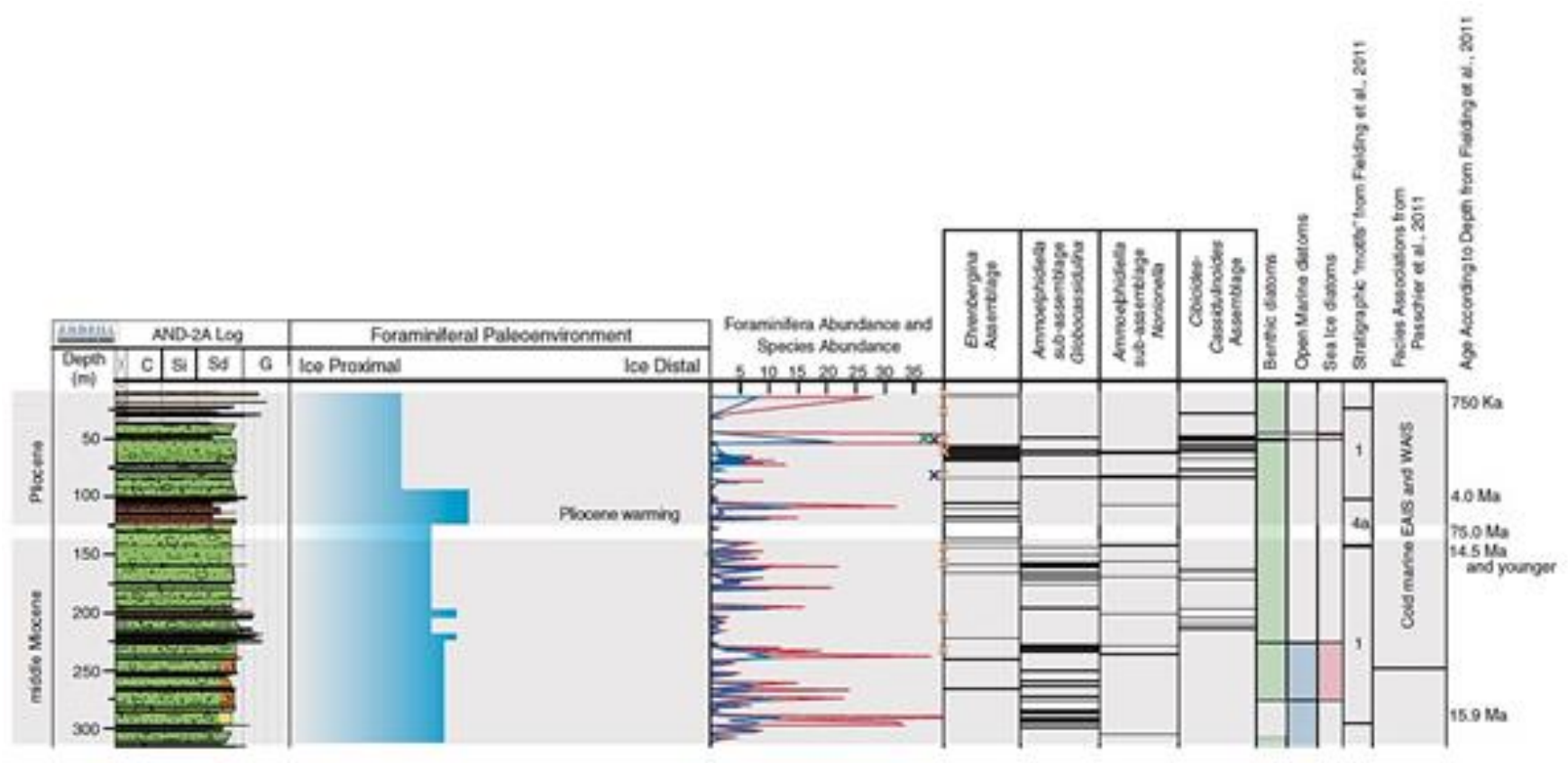

Figure 2.20: Vertical occurrence of foraminiferal assemblages in middle Miocene and Pliocene sediments within the AND-2A core. The Pliocene record contains all three assemblages and points to a depositional environment during the Pliocene that was dominated by a strong glacial influence and more energetic bottom currents. Taxa within the Pliocene assemblage also indicate prolonged episodes of high productivity under open-water conditions with significant reductions in ice volume and little/no seasonal summer sea ice (Patterson and Ishman, 2012).

The previous $\sim 30$ years' worth of integrated seismic and borehole data has produced the bestunderstood sedimentary record on the Antarctic margin, largely thanks to persistent sediment supply and subsidence in the region over the last 45 million years (Florindo et al., 2003). Sedimentological evidence obtained by the Dry Valley Drilling Project (McGinnis et al., 1972; McGinnis, 1981), CIROS (McKelvey, 1975; Barrett, 1989), Cape Roberts Project (Barrett et 
al., 1998; Davey et al. 2001), and ANDRILL Project (Naish et al., 2007a; Naish et al., 2007b; Harwood et al., 2006; Harwood et al., 2009), afford the opportunity to examine how the coastal deposition system in southern Victoria Land and McMurdo Sound has evolved throughout the late Neogene (Levy et al., 2012). These drillcore records provide the physical evidence needed to ground-truth high-resolution model reconstructions of Antarctic ice volume and GMSL variations during past warm climate intervals (e.g. Pollard and DeConto, 2009; DeConto and Pollard, 2016). These models predict several major collapses of the WAIS, as well as deglaciation of marine-based sectors of the EAIS during Plio-Pleistocene interglacials, which correspond well with intervals of diatomaceous sediment in the drillcore record that indicate warmer sea surface temperatures, little or no summer sea ice, and an open marine Ross embayment (Pollard and DeConto, 2009; Raymo and Mitrovica, 2012; DeConto and Pollard, 2016).

Frequent and prolonged simulated collapses of the WAIS in Pollard and DeConto (2009) correspond to the two thickest diatomaceous intervals in AND-1B between 4.3-3.4 Myr ago. A thinner diatomaceous interval in the AND-1B core representing the well-dated MIS 31 event 1.07 Myr ago precisely matches another brief collapse of the WAIS modelled by Pollard and DeConto (2009). More recent simulated collapses, however, do not always coincide with the late Pleistocene interglacials MIS 11 and MIS 5e. Some of the forcings used to drive these simulations e.g. hybrid ice dynamics, parameterised sub-ice melt, calving, and structural icemargin failure, are not fully constrained, and models are unable to account for a number of important feedback mechanisms in the climate. Uncertainties surrounding the influence of local orbital insolation forcing, and the $40 \mathrm{kyr}$ phase relationship of Antarctic sub-ice melt to the benthic oxygen isotope record, for example, may lead to imprecise timings (Pollard and DeConto, 2009; DeConto and Pollard, 2016). Despite limitations, these simulations are capable of reconstructing two very different episodes of ice-retreat and associated rise in GMSL during the warmer Pliocene and LIG (DeConto and Pollard, 2016). 

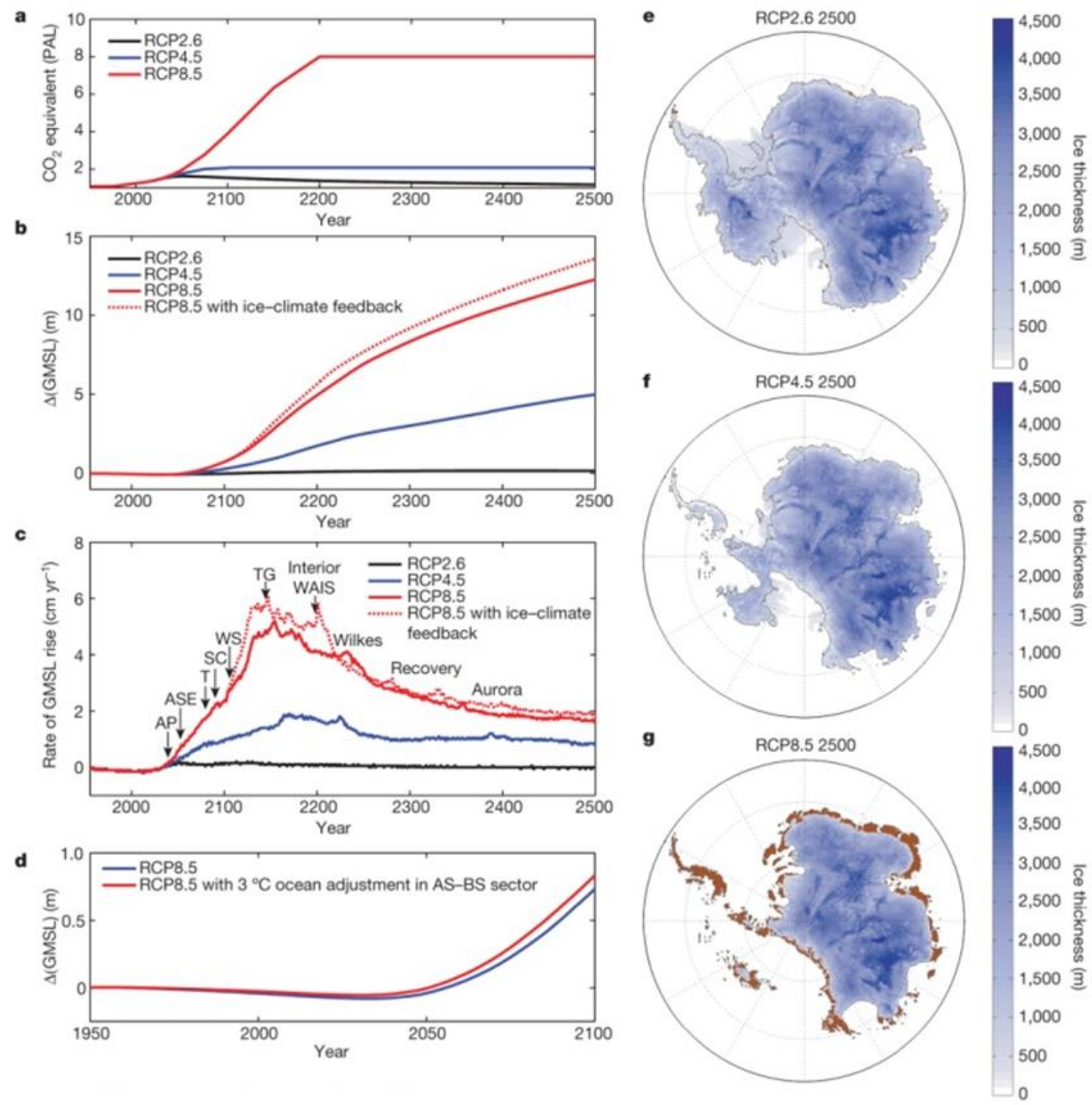

Figure 2.21: Simulated future scenarios with elevated greenhouse gas emissions, DeConto and Pollard (2016) highlight the potential for Antarctica to contribute $>1 \mathrm{~m}$ of GMSL rise by 2100 , and a further $>15 \mathrm{~m}$ over the next 500 years (DeConto and Pollard, 2016). a) $\mathrm{CO}^{2}$ forcing follows RCP emission scenarios set out in Meinshausen et al. (2011); b) shows the contribution of Antarctic ice volume to GMSL; c) rate of sea-level rise and approximate timing of major ice retreat and thinning; d) Antarctic contribution to GMSL over the next 100 years for RCP8.5 with and without a $3^{\circ} \mathrm{C}$ warming adjustment in model ocean temperatures; e-g) snapshots of ice volume at 2500 as per RCP2.6 (e), RCP4.5 (f), and RCP8.5 (g) (DeConto and Pollard, 2016).

When applying these model physics to future scenarios with elevated greenhouse gas emissions, DeConto and Pollard (2016) highlight the potential for Antarctica to contribute > 1 $\mathrm{m}$ of GMSL rise by 2100, and a further $>15 \mathrm{~m}$ over the next 500 years (Fig. 2.21) (DeConto and Pollard, 2016). The projected onset of major ice-sheet retreat occurs much sooner under RPC8.5 (IPCC, 2013) at around 2050, and is estimated to start increasing at a rate of $>4 \mathrm{~cm}$ 
$\mathrm{yr}^{-1}$ after 2100 (DeConto and Pollard, 2016). The application of model physics in this study that are capable of linking ice dynamics and surface meltwater via structural failure of marineterminating ice cliffs and hydrofracturing of buttressing ice shelves (DeConto and Pollard, 2016) have produced GMSL estimates at the more extreme end of the scale than previous studies (Golledge et al., 2015; Winkelmann et al., 2015; Ritz et al., 2015). These studies conclude that although ocean-driven melt is an important driver of grounding-line retreat, atmospheric warming is expected to overtake the ocean as the main driving force of Antarctic ice loss in scenarios with elevation greenhouse gas emissions (DeConto and Pollard, 2016). The long thermal memory of the ocean ( $\mathrm{Li}$ et al., 2013) is predicted to have a profound influence on the recovery of marine-based ice and inhibit the re-advance of ice sheets for thousands of years, even after the curtailing of greenhouse gas emissions (DeConto and Pollard, 2016).

\subsection{Study site locations and characteristics}

The fossil-bearing glacimarine sediments being investigated in thesis are located on the slopes of the volcanoes of Mount Discovery and Brown Peninsula in Southern McMurdo Sound, Antarctica (Fig. 2.22). The region is surrounded by the Royal Society Ranges to the west, Mount Discovery and Minna Bluff in the south, and Ross Island to the north (Fig. 2.22). The glaciated and eroded volcanic edifices of Mount Discovery and Brown Peninsula define the southern boundary of the McMurdo Ice Shelf, an extension of the Ross Ice Shelf that covers much of present-day southern McMurdo Sound. Extensive ablation areas are a prevalent feature across the northern flanks of Mount Discovery (Fig. 2.22) and Brown Peninsula with the emplacement of the Mount Morning/Mount Discovery/Minna Bluff complex acting as a high topographic barrier that deflects the northward-flowing Ross Ice Shelf around McMurdo Sound (Denton and Marchant, 2000). As a result, the prevailing south-westerly winds are the dominant factor in controlling the expanse and distribution of these ice-free areas by depositing snow on the upwind southwest-ward-facing slopes and valleys and ablating the downwind northeast-ward-facing flanks (Fig. 2.22) (Denton and Marchant, 2000). Glacially-transported sediments blanket the landscape in series of hummocky moraines and drift sheets (Fig. 2.25) that have been used in previous investigations to reconstruct the extent of past ice grounding events in southern McMurdo Sound (Stuiver et al., 1981; Kellogg et al., 1990; Denton and Marchant, 2000; Wilson et al, 2000; Anderson et al, 2017). 


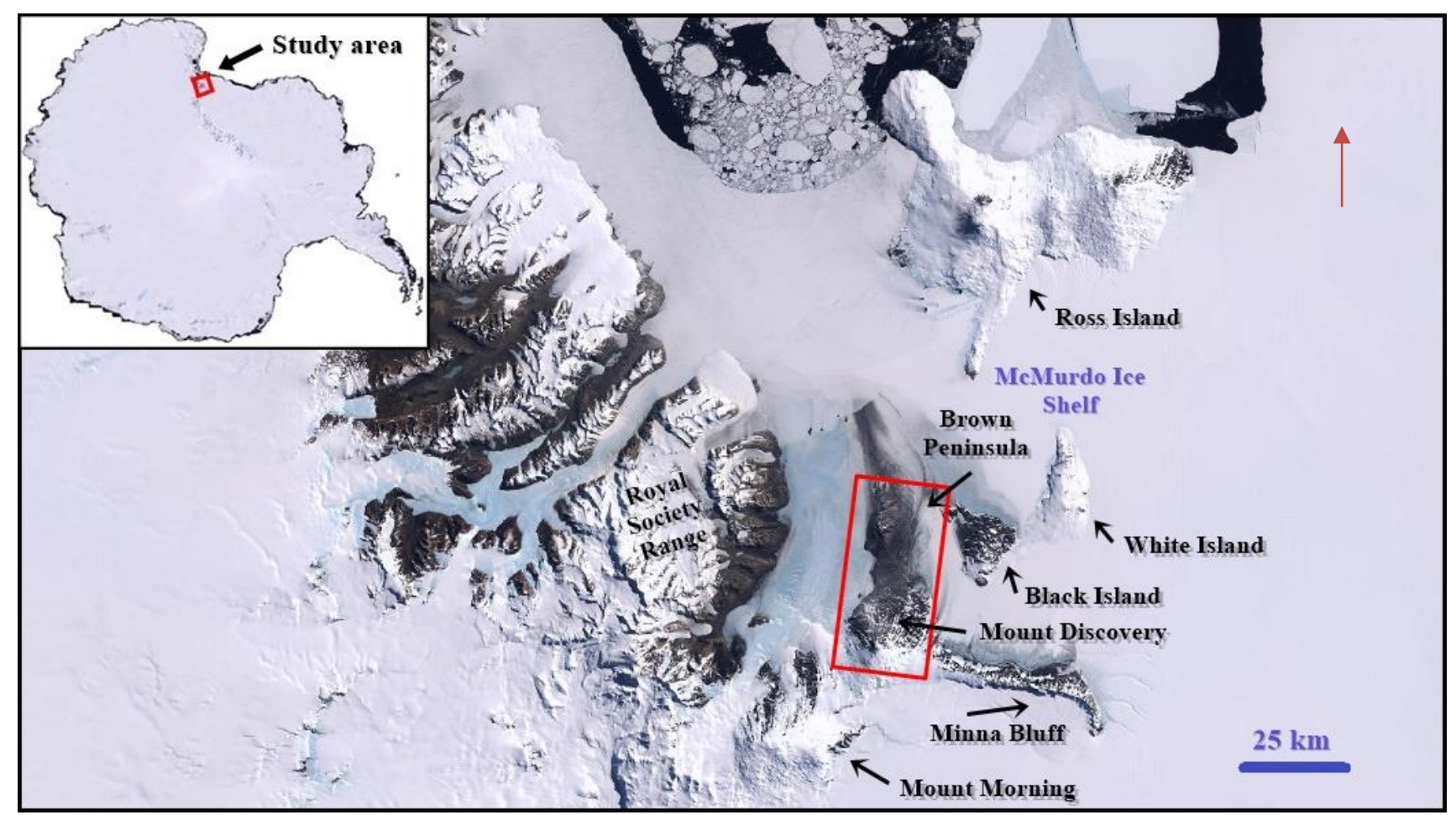

Figure 2.22: Study area encompassing Mount Discovery and Brown Peninsula, southern McMurdo Sound. Map indicates the Royal Society Ranges to the west, Mount Discovery and Minna Bluff in the south, and Ross Island to the north, as well as islands of the Ross Archipelago distributed throughout. Mount Discovery and Brown Peninsula mark the outer limits of the McMurdo Ice Shelf, an extension of the Ross Ice Shelf that covers much of present-day southern McMurdo Sound (Denton and Marchant, 2000; Wilson et al., 2000). Red arrow indicates north.

Mount Discovery is a large stratovolcano that exists as part of a sequence of alkaline igneous rocks that collectively form the Erebus Volcanic Province. Together with the Hallett and Melbourne Volcanic Provinces these volcanic rocks make up McMurdo Volcanic Group which extends at least $800 \mathrm{~km}$ along the western margin of the Ross Embayment from Cape Adare southwards to the Ross Ice Shelf (Kyle, 1990). Mount Discovery has a recognisable dome-like shape on its northern flanks, is almost entirely free of glacial ice, and is draped in what is known as the Ross Sea Drift (RSD) (Fig. 2.25). The RSD on Mount Discovery has been associated with expansion of a grounded ice sheet in western Ross Sea during the Last Glacial Maximum (24-18ka) and is comprised of loose cobbles and gravels set within a matrix of slightly bedded sands. The RSD forms a nearly continuous ice-cored drift sheet that reaches from the ice shelf surface to a maximum height of 519 m elevation, while older drift sheet material sits atop it in places but extends no higher than $805 \mathrm{~m}$ (Denton and Marchant, 2000). These glacial sediments exhibit well-developed thermokarst features, and post-depositional gelifluction and solifluction 
associated with seasonal free-thaw action (Fig. 2.25). Preserved within these drift sediments at elevations of $197.71 \mathrm{~m}$ and $221.23 \mathrm{~m}$ respectively are the in-situ glacimarine sequences referred to throughout this study as DO1A (78.260852S, 165.358614E) (Fig. 2.23) and DO3A (Fig. $2.23)(78.26674 \mathrm{~S}, 165.365940 \mathrm{E})$.

\section{Map of Mt Discovery site setting}

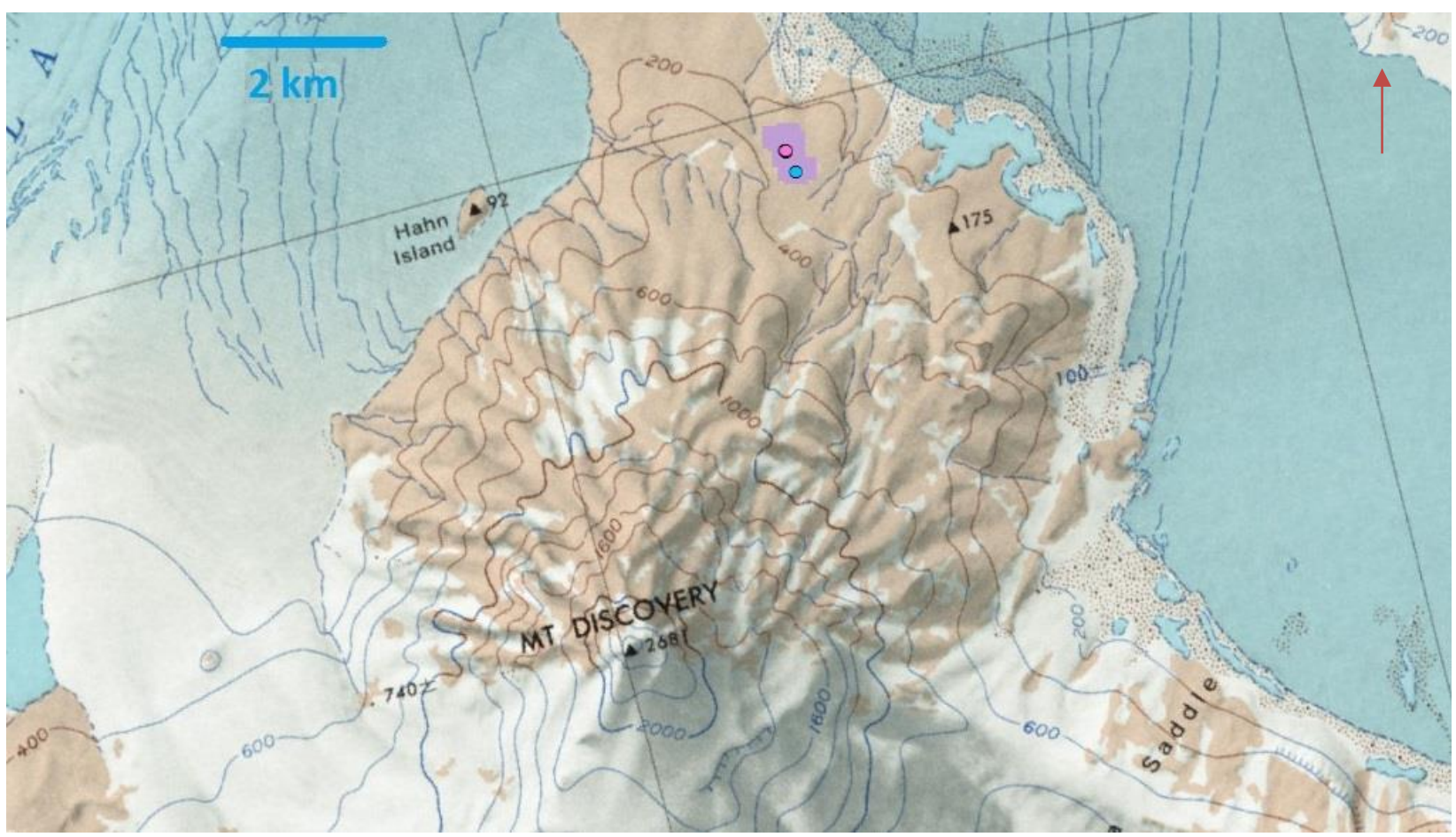

Figure 2.23: USGS topographic map showing sample locations (DO1A pink, DO3A blue) on the flanks of Mount Discovery, McMurdo Sound. Dispersal of marine invertebrate fossil remains identified in the region indicated by purple shading. Red arrow indicates north.

Approximately $17 \mathrm{~km}$ north of DO1A and DO3A lie two additional fossiliferous glacial deposits known as BO1A (78.11042S, 165.529875E) and BO1B (78.102514S, 165.542996E) (Fig. 2.24). These glacimarine sequences are located at an altitude of $128.7 \mathrm{~m}$ and $131.83 \mathrm{~m}$ along the eastern shoreline of Brown Peninsula where the region is covered by a poorly-sorted drift sheet that, in similar fashion to the nearby Mount Discovery RSD, is ice-cored and comprised of predominantly local volcanic clasts set within a weakly-stratified sandstone matrix. The morphology of the drift sheet surrounding these deposits is characterised by undulating moraines that reach their maximum elevation of $360 \mathrm{~m}$ on the eastern flank of Brown Peninsula, and are again overlain by an older glaciogenic deposit that extends no higher 
than $400 \mathrm{~m}$. Brown Peninsula is an important site for this project and was targeted specifically for exposures of the previously-described Scallop Hill and Taylor Formations (Speden, 1962; Eggers, 1979). It was hoped that retracing the steps of VUWAE 20 (Fig. 2.24) would uncover the in-situ stratigraphy characterised by Eggers in 1975 (Fig. 2.3), which in turn would have provided a means of correlating and dating fossiliferous deposits observed nearby on Mount Discovery with a glacimarine sequence of known age. BO1A and BO1B occur at slightly lower elevations of $128.7 \mathrm{~m}$ and $131.83 \mathrm{~m}$ compared to their southern Mount Discovery counterparts, and are also inferred to be one composite stratigraphic section rather than two individual glacimarine sequences as is the case with DO1A and DO3A. It is thought that post-depositional development of hummocky moraine topography has offset BO1A and BO1B horizontally in the order of a few metres with BO1B presumed to overlie BO1A stratigraphically.

\section{Map of Brown Peninsula site setting}

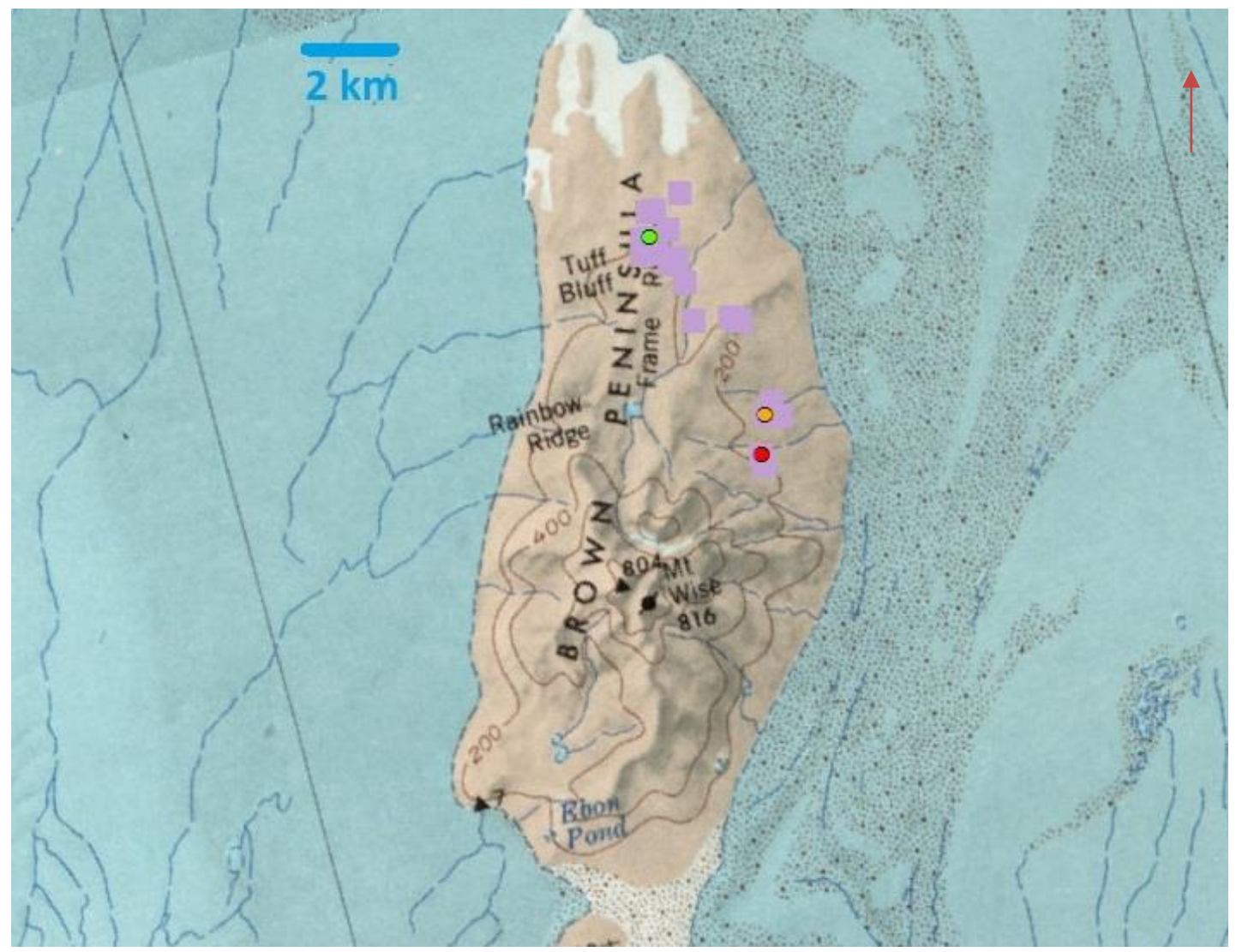

Figure 2.24: USGS topographic map of sample locations on Brown Peninsula, McMurdo Sound. BO1A shown indicated in red, BO1B shown in orange. VUWAE 20 camp marked in green. Occurrence of marine invertebrate fossil remains shaded in purple. Red arrow indicates north. 
A number of different studies have attempted to both reconstruct the eruptive histories of the volcanic edifices in southern McMurdo Sound (e.g. Cooper et al., 2007; Aitken et al., 2012) and constrain the amplitude of flexural deformation and processes of basin formation induced by the superposed load of the Ross Archipelago (Stern et al., 1991; Melhuish et al., 1995; Horgan et al., 2005). Minna Bluff represents the earliest eruptive episode in the region, producing a reasonably continuous record of basanitic, trachyitic, and phonolitic volcanism throughout 10.04-7.26 Ma (Aitken et al., 2012). The emplacement of Mount Discovery is thought to be the next major load-building event in the sequence. Interbedded benmoreite lava flows, debris flows, and volcanogenic sediments found within the volcanic core of Mount Discovery suggest that the main loading event occurred at $\sim 5.3 \mathrm{Ma}$ and continued through until 1.87 Ma (Aitken et al., 2012). A period of distributed load-building followed the emplacement of Mount Discovery from 5-3 Ma during which White Island, Black Island, Mount Bird, and Brown Peninsula were erupted (Cooper et al., 2007; Aitken et al., 2012). Significant overlap in the eruptive histories of these volcanoes, and limited evidence that these early episodes of load-building occurred simultaneously, hint at the formation of a submarine plateau onto which these volcanoes were established (Cooper et al., 2007; Aitken et al., 2012).

Although volcanic loading is known to produce lithospheric flexure in the region, the emplacement of Ross Island on the crust between 5 to $1 \mathrm{Ma}$, cannot account for the uplift of the deposits on the flanks of Mount Discovery and Brown Peninsula, as these sites are not located on the peripheral bulge of the flexure (Aitkin et al., 2012). Instead, this study considers the effect of changes in ice volume and extent on the underlying crust, and interprets the elevation history of the sites in terms of the viscoelastic response of the crust due to as isostatic rebound as a response of ice loading and unloading, and glacial incision and erosion in the Transantarctic Mountains (e.g. Stern et al., 2005). 


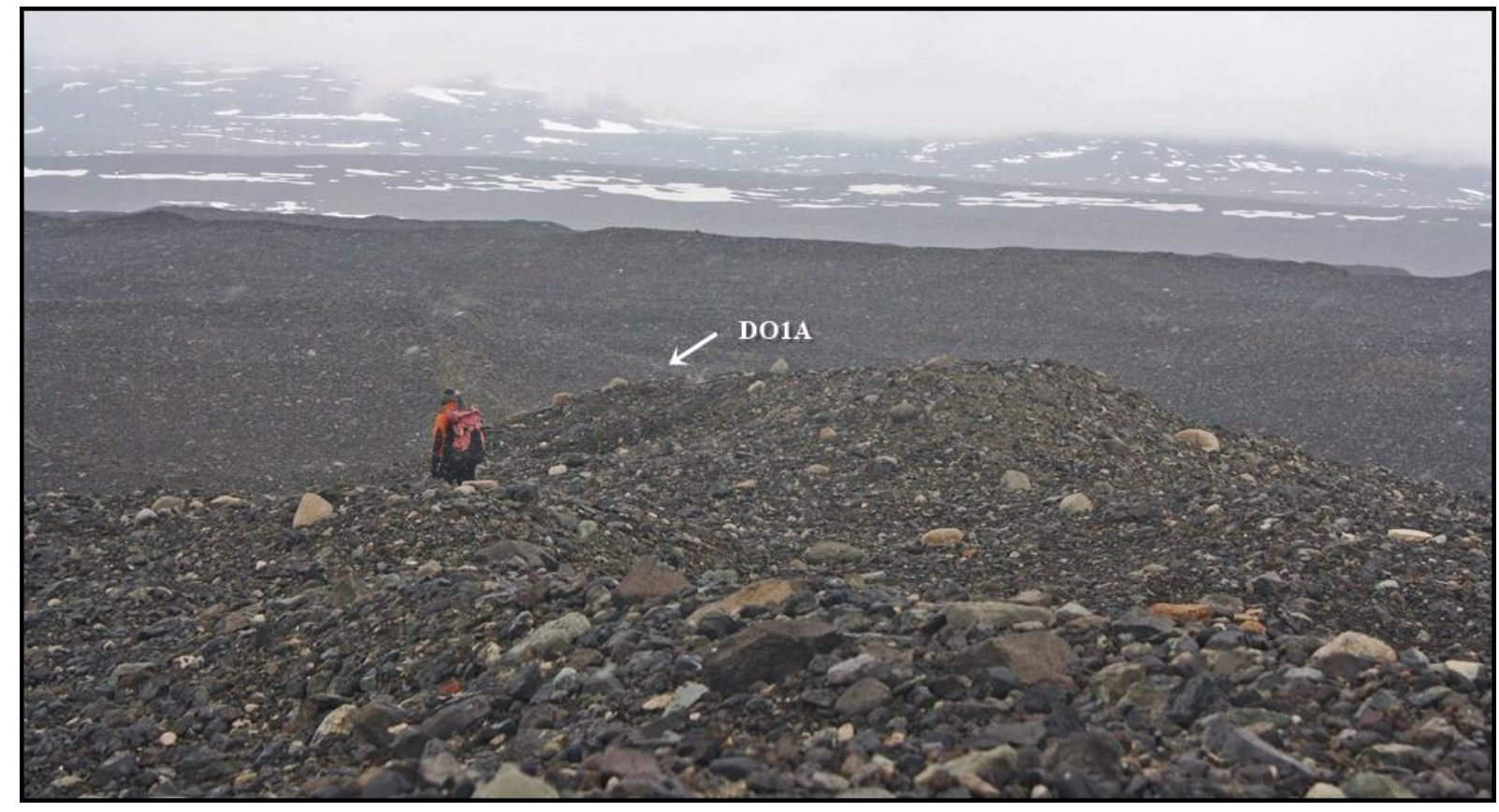

Figure 2.25: Surface topography on the northern face of Mount Discovery surrounding glacimarine sequence DO1A. Glacially-transported sediments blanket the landscape in series of hummocky moraines and drift sheets that have been used in previous investigations to reconstruct the extent of past ice grounding events in southern McMurdo Sound (Stuiver et al., 1981; Kellogg et al., 1990; Denton and Marchant, 2000; Wilson et al, 2000; Anderson et al, 2017). These glacial remains exhibit well-developed thermokarst features, and post-depositional gelifluction and solifluction associated with seasonal free-thaw action (Denton and Marchant, 2000). Person included for scale. 


\section{Methodology and background to approaches being used}

\subsection{Field work: sampling and stratigraphic description}

Field work for this project was carried out from January 19-26 during the austral summer of 2016. Glacimarine sequences DO1A, DO3A, BO1A, and BO1B, on the flanks of Mount Discovery and Brown Peninsula were identified following a high-precision GPS survey of each study area. Vertical trenches were excavated through the glacimarine deposits in an attempt to remove any surface debris material and expose a fresh surface of underlying in-situ stratigraphy (Fig. 3.2). The trenches were opened to the depth of the icecemented sediments, and described before surface melting obscured primary sedimentary features (Fig. 3.1). The sections were measured by tape and lithostratigraphic descriptions made. Lithostratigraphic units were identified on the basis of distinctive lithofacies, recording details about visible features such as colour, bedding thicknesses and relationships, fossil content, sediment texture, fabric, and any sedimentary structures. These descriptions together with

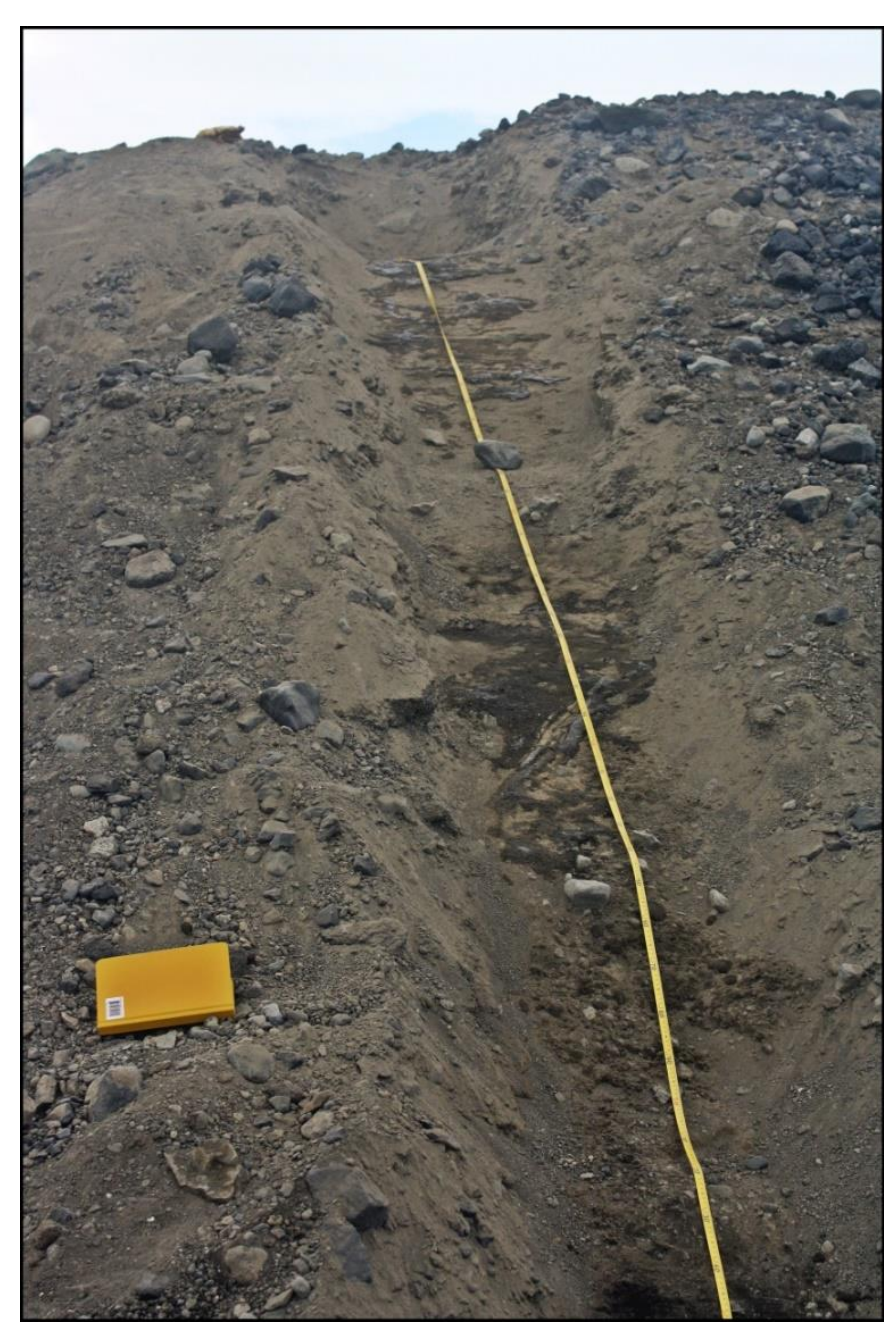

Figure 3.1: Trenched stratigraphic section of DO3A. Notebook included for scale. analytical methods described below formed the basis of the facies and depositional environment interpretation. A total of 43 bulk samples ranging from less than 100 grams to over 200 grams in weight were obtained at $30 \mathrm{~cm}$ intervals from each of the six metres of stratigraphic section on Mount Discovery, which in general enabled all the lithologic units to be sampled. Likewise, eight bulk samples were extracted from BO1A and BO1B and labelled following the same methodology. After the completion of sampling, each stratigraphic trench was infilled with its original debris material so as to restore the glacial deposits to their previously near-undisturbed state. 


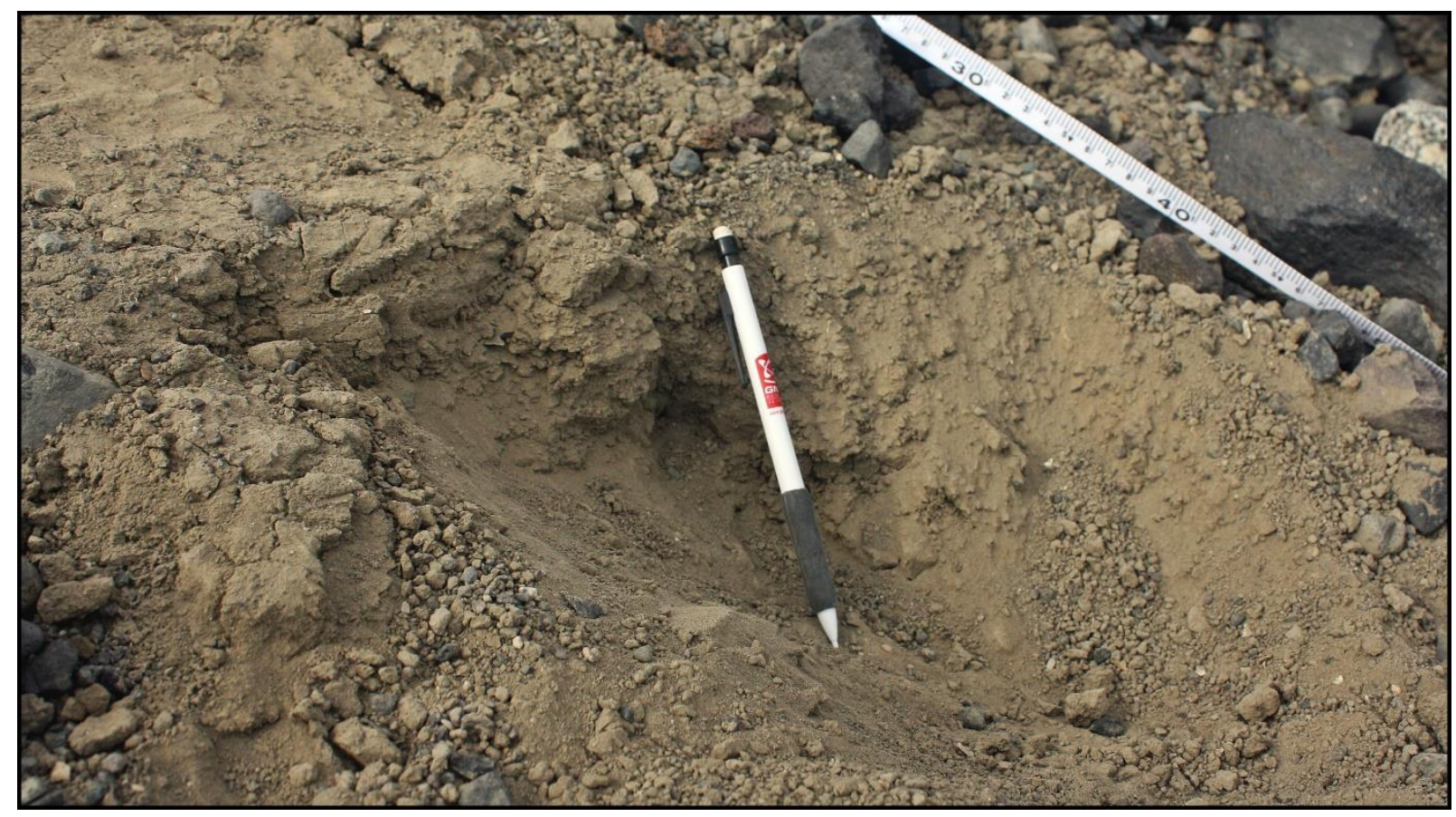

Figure 3.2: Underlying in-situ stratigraphy at $30-40 \mathrm{~cm}$ depth prior to trenching DO3A. Pencil included for scale.

\subsection{Sediment texture and facies analysis as an indicator of grounding line variability}

Grain size of siliciclastic sediments can be used to make assumptions about changes in past depositional environments. The textural signatures of glacimarine strata are a reflection of variations in water depth and glacial proximity. Under conditions of a wave-graded shoreline, when the glacier is land terminating, a trend of fining with increasing depth may occur as wave energy on the seafloor decreases with depth, (Barrett, 1989; Dunbar et al., 2008; Boggs, 2011). Alternatively the proximity of the grounding line of a tide-water glacier can be inferred from coarseness of sediments. Gravel, poorly sorted sand, and diamictite textures are associated with the grounding zone, whereas finer grained pelagic and hemi-pelagic sediments are associated with more ice distal marine environments (Fielding et al., 2000; Naish et al., 2006; Krissek et al., 2007; Naish et al., 2007a; 2007b).

The use of sediment texture in this study as an indication of distance from a marine-terminating ice margin in southern McMurdo Sound follows similar attempts made with sediments from the Scallop Hill and Taylor Formations (Speden, 1962; Vella, 1969; Eggers, 1979), and interpretations are largely based on previous approaches used to analyse drillcore sediments recovered by the ANDRILL Program (Fig. 3.3) (e.g. Naish et al., 2006; Krissek et al., 2007; 
McKay et al., 2009). This study recognises that major changes in lithology may arise from a shift in the sedimentary environment between ice-distal and ice-proximal conditions (McKay et al., 2009). Changes in sediment texture and lithofacies will be used to establish a glacimarine sequence stratigraphic framework for interpreting the paleoenvironmental significance of results obtained from grain size analyses of $\mathrm{DO} 1 \mathrm{~A} / 3 \mathrm{~A}$ and $\mathrm{BO} 1 \mathrm{AB}$.

\begin{tabular}{|c|c|c|c|c|c|}
\hline \multicolumn{6}{|c|}{ PERCENT GRAVEL $(>2 \mathrm{~mm})$ IN WHOLE ROCK ESTIMATED FROM CORE } \\
\hline & Trace $(<1 \%)$ & $1-5 \%$ & $5-30 \%$ & $30-80 \%$ & $>80 \%$ \\
\hline \multirow{4}{*}{$\begin{array}{l}\text { FINE-GRAINED } \\
\text { SEDIMENTS }\end{array}$} & $\begin{array}{l}\text { MUDSTONE with } \\
\text { dispersed clasts }\end{array}$ & $\begin{array}{l}\text { MUDSTONE with } \\
\text { common clasts }\end{array}$ & $\begin{array}{l}\text { MUDSTONE with } \\
\text { abundanct } \\
\text { clasts }\end{array}$ & $\begin{array}{c}\text { Muddy } \\
\text { CONGLOMERATE / } \\
\text { BRECCIA }\end{array}$ & \multirow{4}{*}{$\begin{array}{c}\text { CONGLOMERATE } \\
\text { / BRECCIA }\end{array}$} \\
\hline & $\begin{array}{l}\text { Sandy } \\
\text { MUDSTONE with } \\
\text { dispersed clasts }\end{array}$ & $\begin{array}{l}\text { Clast-poor } \\
\text { muddy } \\
\text { DIAMICTITE }\end{array}$ & $\begin{array}{l}\text { Clast-rich muddy } \\
\text { DIAMICTITE }\end{array}$ & $\begin{array}{c}\text { Sandy muddy } \\
\text { CONGLOMERATE / } \\
\text { BRECCIA }\end{array}$ & \\
\hline & $\begin{array}{l}\text { Muddy } \\
\text { SANDSTONE with } \\
\text { dispersed clasts }\end{array}$ & $\begin{array}{l}\text { Clast-poor } \\
\text { sandy } \\
\text { DIAMICTITE }\end{array}$ & $\begin{array}{c}\text { Clast-rich sandy } \\
\text { DIAMICTITE }\end{array}$ & $\begin{array}{c}\text { Muddy sandy } \\
\text { CONGLOMERATE / } \\
\text { BRECCIA }\end{array}$ & \\
\hline & $\begin{array}{l}\text { SANDSTONE with } \\
\text { dispersed clasts }\end{array}$ & $\begin{array}{l}\text { SANDSTONE } \\
\text { with common } \\
\text { clasts }\end{array}$ & $\begin{array}{l}\text { SANDSTONE with } \\
\text { abundant clasts }\end{array}$ & $\begin{array}{c}\text { Sandy } \\
\text { CONGLOMERATE / } \\
\text { BRECCIA }\end{array}$ & \\
\hline
\end{tabular}

Figure 3.3: Classification scheme used for poorly sorted terrigenous clastic sediments containing gravel sized clasts (re-drawn from Naish et al., (2006), modified from Moncrieff, 1989)).

\subsection{Laboratory Techniques}

The first stage of sample preparation for all bulk samples was carried out at GNS Science's sedimentology and micropaleontology laboratories in Lower Hutt. Each bulk sample was dried overnight in a $40^{\circ} \mathrm{C}$ oven before being gently disaggregated and separated with a riffle splitter into four equally representative subsamples. From this point on samples earmarked for grain size analysis were taken to Victoria University of Wellington where further treatment could be applied.

Grainsize fractions were sieved at the $2 \mathrm{~mm}, 250 \mu \mathrm{m}$ to $2 \mathrm{~mm}$, and < $250 \mu \mathrm{m}$, boundaries. Each grainsize fraction was weighed before the remaining fine fraction was split once more using a riffle splitter into $\sim 3$ gram sub-samples divided amongst racks of $50 \mathrm{~mL}$ centrifuge tubes. Batches of grain size samples were then submerged in a $65^{\circ} \mathrm{C}$ water bath where $10 \%$ hydrochloric acid was added to destroy any calcium carbonate material. After being left to 
digest for an hour, samples were rinsed and centrifuged three times with de-ionised water before returning to the water bath again. $27 \%$ hydrogen peroxide was added periodically to the samples for a further 24-48 hours, or until all visible reactions stopped occurring, to ensure all remaining organic material was destroyed. Samples were washed again with de-ionised water and centrifuged another three times before being frozen overnight and finally freeze dried for analysis with the Beckman Coulter LS 13320 Laser Diffraction Particle Size Analyser.

To be within an adequate obscuration of 6-14\%, sub-samples were split with a riffle splitter into 0.1- $0.2 \mathrm{~g}$ sub-samples before being analysed with the LPS. These were then were soaked in a $\sim 30 \mathrm{~mL}$ mixture of $0.5 \mathrm{~g} / \mathrm{L}$ of Calgon (sodium hexametaphosphate) and de-ionised water while being sonicated for ten minutes immediately prior to measurements being taken to ensure the complete disaggregation of sediments. To test the accuracy of the LSP, $68 \mu$ glass bead standards were run at the beginning and end of each working day. Samples were analysed for 60 seconds on the LSP, and in between each run the laser was re-aligned and the background was measured. The offset was measured every 30 minutes, and the LSP automatically rinsed for 3 minutes after each run. Measurements were calibrated using the quartz natural model.

Repeat runs were carried out to ensure good reproducibility and accurate results. A strong correlation exists $\left(r^{2}=0.88\right)$ between the mud content of original measurements and repeat samples (Fig. 3.4) which enables some confidence in the reproducibility of results and also in the precision of subsampling. The data collected from LPS measurements has been statistically analysed using the grainsize software GRADISTAT (Blott, 2010; Blott and Pye, 2011). The results of the LPS grainsize analysis and sample statistics are available in appendix B.

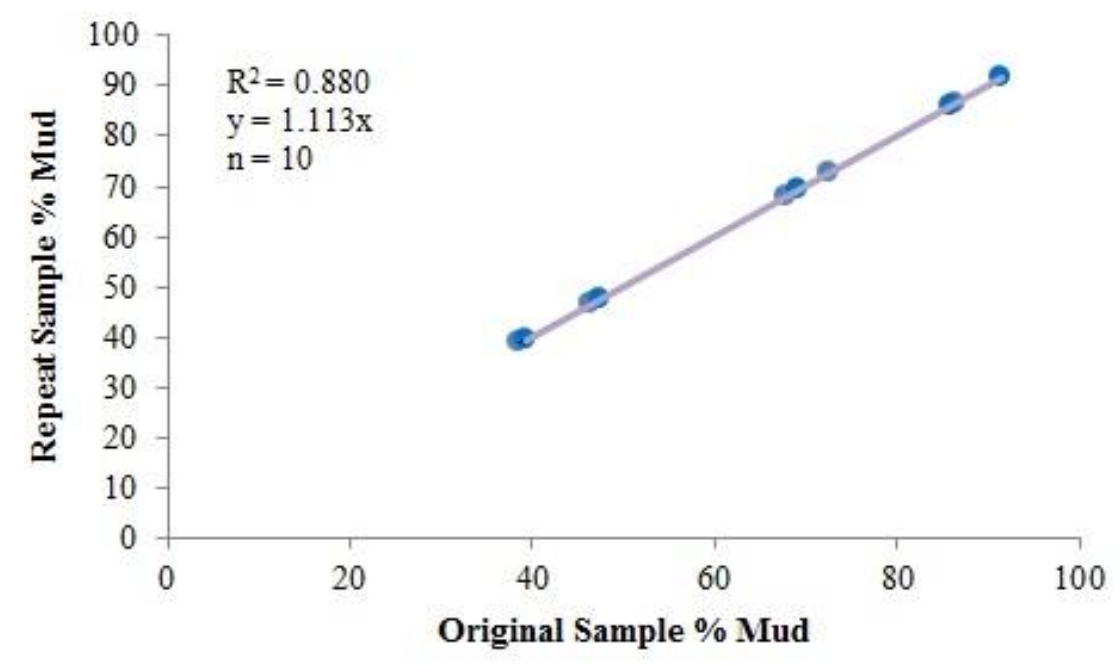

Figure 3.4: Comparison of the mud content or original sample measurements and repeat samples indicated by blue dots. Consistency of results is suggested by a linear trend line (purple) slope of 1.1 and a clustering of points about the regression line. 


\subsection{Foraminiferal paleoecology}

Fossil foraminifera present throughout $\mathrm{DO} 1 \mathrm{~A} / 3 \mathrm{~A}$ and $\mathrm{BO} 1 \mathrm{~A} / \mathrm{B}$ provide another means of reconstructing the depositional environment in a way that is complementary to and independent of sediment texture. Distributed across a broad range of environmental settings from shallow, brackish waters to abyssal ocean, these microfossil shells, or 'tests', built out of secreted calcite have a high preservation potential in marine sediments, and as such have been used extensively as a proxy for inferring past environmental conditions (Hayward et al., 1999; Van der Zwaan et al., 1999; Hayward et al., 2007).

Benthic foraminifera in particular are comprised of both epifaunal species that live above the substrate and infaunal species that burrow beneath seafloor sediments, but their dispersal is controlled by particular affinities for specific environmental variables (Van der Zwaan et al., 1999). Limited knowledge of the interplay between temperature, salinity, oxygen concentration, nutrients, flux of organic matter, current strengths, and $\mathrm{pH}$, in the ocean, as well as other factors such as predation and competition restrict full understanding of how species abundances vary in response to these environmental parameters (Vella, 1962; Hayward et al., 1999; Van der Zwaan et al., 1999). It is largely agreed upon, however, that a source of food in the form of organic matter (Pearson and Rosenberg (1978) and the concentration of oxygen in seafloor sediments and bottom water (Hayward et al., 1999; Rosenberg et al., 2001) are the two dominant variables influencing the distribution of foraminifera species. These important ecological parameters decrease with increasing water depth and undergo the most rapid changes in the upper $\sim 100 \mathrm{~m}$ of surface waters, and as a result assemblages in shallow-water environments have an increased sensitivity to change compared to their deeper-water counterparts (Van der Zwaan et al., 1999). Consequently, it is possible to estimate past water depths, or at least qualitatively assess the degree of oceanicity - that is open ocean vs more restricted coastal and sub ice shelf grounding line environments, which may experience higher turbidity, lower salinity, lack of UV light and be more poorly ventilated, and by a decreasing food supply with depth in neritic conditions (Van der Zwaan et al., 1999).

Confidence in using benthic foraminifera as a paleoenvironmental proxy requires a comprehensive knowledge of modern benthic marine ecology. Many of the species found within Neogene sedimentary records from low-latitude regions are extant in present-day continental shelf and slope sediments (e.g. Hornibrook et al., 1989; Abbott, 1997; Naish and Kamp, 1997a; Hayward et al., 1999). This has enabled comparison between the depth- 
distributions of benthic foraminifera preserved in the geologic record to modern environments. However, few ecological studies exist for high southern latitude foraminfera. The physical and oceanic factors controlling the relative abundance and temporal occurrence of foraminfera around the Antarctic region have been discussed by authors such as McKnight (1962), Pflum (1966), Kennett (1966; 1968), and Quilty (1985). Basic taxonomic information is provided by these previous studies, but further investigation is required before paleoenvironmental interpretations from these microfossil assemblages can be considered reliable (Ishman, 1991). It is widely accepted though that a shallow Carbonate Compensation Depth (CCD) in the Ross Sea is primarily responsible for influencing foraminiferal distributions. Kennett (1986) defines the lower limit of the CCD between 850-560 m, above which both agglutinated and calcareous fauna are mixed. Agglutinated species tend to dominate depths greater than $430 \mathrm{~m}$, whereas calcareous foraminifera are restricted to depths shallower than $550 \mathrm{~m}$ (Kennett, 1986).

An additional factor controlling the dispersal of foraminifera in Antarctic seafloor sediments concerns the differentiation between living and dead specimens (Ward, 1983). This study examined seafloor sediments from a range of water depths and physiographic conditions in McMurdo Sound to try and establish distribution patterns for living foraminifera. A comparison between living and dead assemblages put forward by Ward (1983) provides a measure of reworking due to downslope transport and taphonomic loss via dissolution, and exists as a modern analogue for ancient sediments that no longer contain complete foraminifera assemblages (Ward, 1983). However, an overall poor understanding about the ecological requirements and distribution patterns of modern foraminfera assemblages, and assumptions made when interpreting the fossil assemblages, limit the strength of foraminifera as a paleoenvironmental indicator.

A more comprehensive understanding of recent high southern latitude foraminiferal ecology is presented in Ishman, (1991). This study found that modern environmental conditions in the Antarctic Peninsula fjords and bays are comparable to those of an interglacial. However, distinct regional variations in faunal distributions exist across the Antarctic Peninsula as a result of variations in bottom-water masses (Ishman, 1991). It is thought that these temporal differences in bottom-water are predominantly controlled by the interplay of a high-latitudinal thermal gradient that influences climate patterns and produces localised bottom-water conditions, different physiographical configurations of the fjords and bays across the Peninsula, and/or variations in the amount of $\mathrm{CaCO}_{3}$ corrosive bottom-waters from adjacent ice shelves (Ishman, 1991). These observations discussed by Ishman (1991) demonstrate that 
water depth and CCD alone cannot explain the relative abundance and dispersal of benthic foraminfera in the Antarctic region. Ishman (1991) concludes that further physicochemical analyses of bottom-water conditions and seafloor sediments are necessary for an accurate assessment of faunal-habitat associations.

Despite difficulties establishing reliable modern analogues for paleoenvironmental interpretations of the Antarctic region, Neogene benthic foraminiferal assemblages have been used in previous studies, e.g. Cape Roberts, to reconstruct paleoenvironmental conditions in McMurdo Sound. A total of 135 and 151 samples were selected from CRP-2/2A and CRP-3 respectively to be inspected for foraminifera (Cape Roberts Science Team, 1999). The faunal assemblages preserved in CRP-2/2A suggest deposition in an inshore benthic marine environment that was restricted from ocean circulation and susceptible to glacially-influenced processes, e.g. meltwater affecting salinity levels, which may have contributed to limiting the assemblages. It is thought that variations in the abundance of foraminifera within CRP-2/2A correspond to a trend of bathymetric deepening; species abundance peaks as water depth increases to shelf/slope conditions, and decreases in diversity as shallow water taxa return to an inshore depositional environment. Similarly, foraminifera assemblages observed in CRP-3 are characteristic of a depositional environment isolated from ocean circulation where glacially-influenced variations in salinity levels may have limited species diversity and abundance (Cape Roberts Science Team, 1999). Taxa identified in CRP-3 represent deposition in a slightly deeper setting on the mid- to outer- Antarctic Shelf. Collectively, foraminifera recovered throughout these two Cape Roberts drillcores reflect present-day Ross Sea faunal assemblages, but age ranges for the species identified are either too long or poorly constrained and in turn provide no age diagnosis.

\subsection{Laboratory Techniques}

Foraminiferal samples were treated for examination at GNS Science's Avalon micropaleontology laboratory according to the method outlined in Naish and Kamp (1997b). Samples set aside for foraminiferal investigation during the initial stage of sample splitting were wet sieved through a $65 \mu \mathrm{m}$ mesh that was intermittently dyed with a blue methylene epoxy resin to catch out any contaminant specimens before samples were dried overnight again in a low temperature $\left(40^{\circ} \mathrm{C}\right)$ oven. From here samples were taken to Victoria University of Wellington where they were sieved once more at $1000 \mu \mathrm{m}$ and $500 \mu \mathrm{m}$ to remove unwanted 
coarse material. Foraminifera were picked from the remaining sediment until samples were either barren or until > 200 specimens were collected.

\section{6 ${ }^{14} \mathrm{C}$ Dating}

The barnacle Bathylasma corolliforme precipitates calcite shells in a similar fashion to molluscs (Rodriguez-Navarro et al., 2006). Calcite crystal growth is regulated by a supply of $\mathrm{Ca}^{2+}$ and $\mathrm{HCO}^{3-}$ ions and specific organic components secreted by mantle epithelial cells (Rodriguez-Navarro et al., 2006). Today the benthic species has a circumpolar distribution south of the Antarctic convergence (Dayton et al., 1982), but the occurrence of Bathylasma corolliforme within deposits of the Scallop Hill Formation reveals that the species has previously lived in the McMurdo Sound region (Speden, 1962; Dayton et al., 1982). A complicated Antarctic $\mathrm{CO}_{2}$ reservoir effect, however, means radiocarbon dating Antarctic material is not without its limitations. The upwelling of deep waters containing old radio carbon and the contribution of $\mathrm{CO}_{2}$ from ${ }^{14} \mathrm{C}$-depleted glacial meltwater, can result in apparently older radiocarbon ages (Rathburn et al., 1997). The incorporation of old, recycled carbon into shell material and tissues often causes biogenic material from modern Antarctic marine samples to return $\mathrm{C}^{14}$ ages in excess of 1000-5500 years. To account for these effects, a correction factor of 1300 years is typically applied (Goodwin, 1993). Additionally, the remobilisation and transport of older material can also influence radiocarbon ages, as can the reworking of old shells into younger sediments (Domack et al., 1989; Rathburn et al., 1997).

Radiocarbon analysis was carried out at GNS Science's National Isotope Centre in Lower Hutt. $1882.6 \mathrm{mg}$ and $386.9 \mathrm{mg}$ of raw sample from the uppermost fossiliferous units of DO1A and $\mathrm{BO} 1 \mathrm{~B}$, comprising shell hash and larger fragments of Bathylasma corolliforme, were sent away for analysis. One fragment of Bathylasma corolliforme was selected as a subsample from each. These fragments were scraped clean of surface sediment using a scalpel before being acid etched in $0.5 \mathrm{M}$ hydrochloric acid and dried in a vacuum oven. Samples were then ground in a mortar and pestle and transferred to a glass vial for evolution. Carbon dioxide was generated by carbonate $\mathrm{CO}_{2}$ evolution and 1-1.1 mgC was obtained. Sample carbon dioxide was converted to graphite by reduction with hydrogen over iron catalyst before $\mathrm{C}^{14}$ measurements were recorded according to standard procedures (Stuiver and Polach, 1977; Donahue et al., 1990). 


\section{Results}

The following section presents the lithofacies analysis of glacimarine sequences DO1A/3A and $\mathrm{BO} 1 \mathrm{AB}$ depicted below as graphic logs. Six facies are classified based on a range of different sedimentological features (summarised in Table. 4.4), including texture, colour, fossil content, sedimentary structures, and bedding contacts. Each facies have distributions characteristic of the fine fraction and these are plotted in Figures 4.11-4.12-4.13. Grainsize distributions for each sample are plotted in Figure 4.14 Followed by each facies description are a number of possible depositional environments that these sediments represent, with evidence supported by earlier investigations of high-latitude glacimarine sedimentary environments. The vertical succession of glacimarine lithofacies recognised throughout $\mathrm{DO} 1 \mathrm{~A} / 3 \mathrm{~A}$ and $\mathrm{BO} 1 \mathrm{AB}$ provides a framework for paleoenvironmental interpretations, and assists in establishing the dominant depositional processes. Full sedimentological descriptions for each lithologic unit are available in Appendix C. 
D01A Lithologic Log

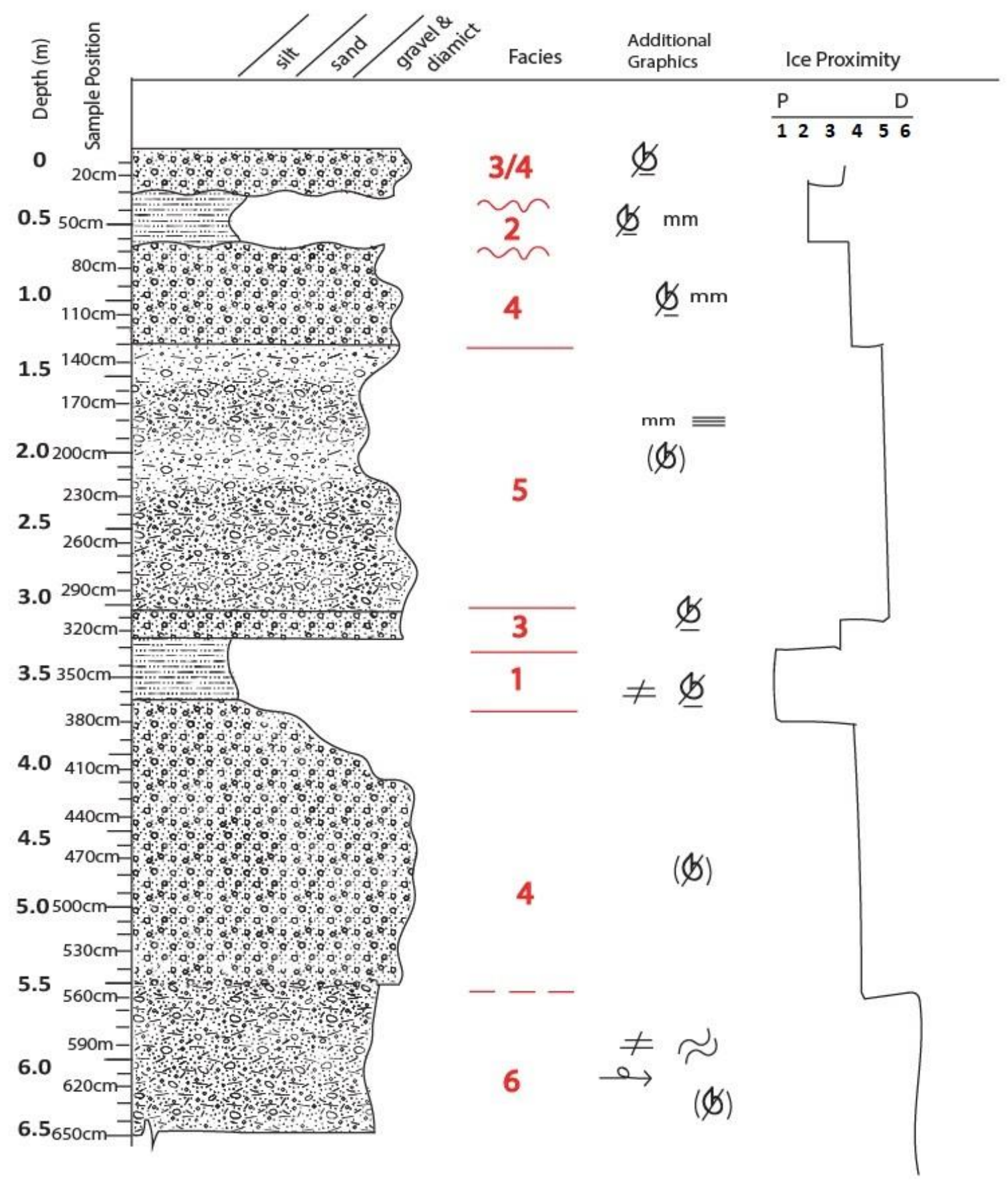

Figure 4.1: DO1A lithologic log. Ice proximity curve inferred from a combination of sediment texture, lithofacies analysis, and faunal content of each facies. Facies number and nature of contact indicated in red, dashed line indicates gradational but otherwise contacts are sharp. Refer to legend on page 59 for explanation of additional graphics. 
DO3A Lithologic Log

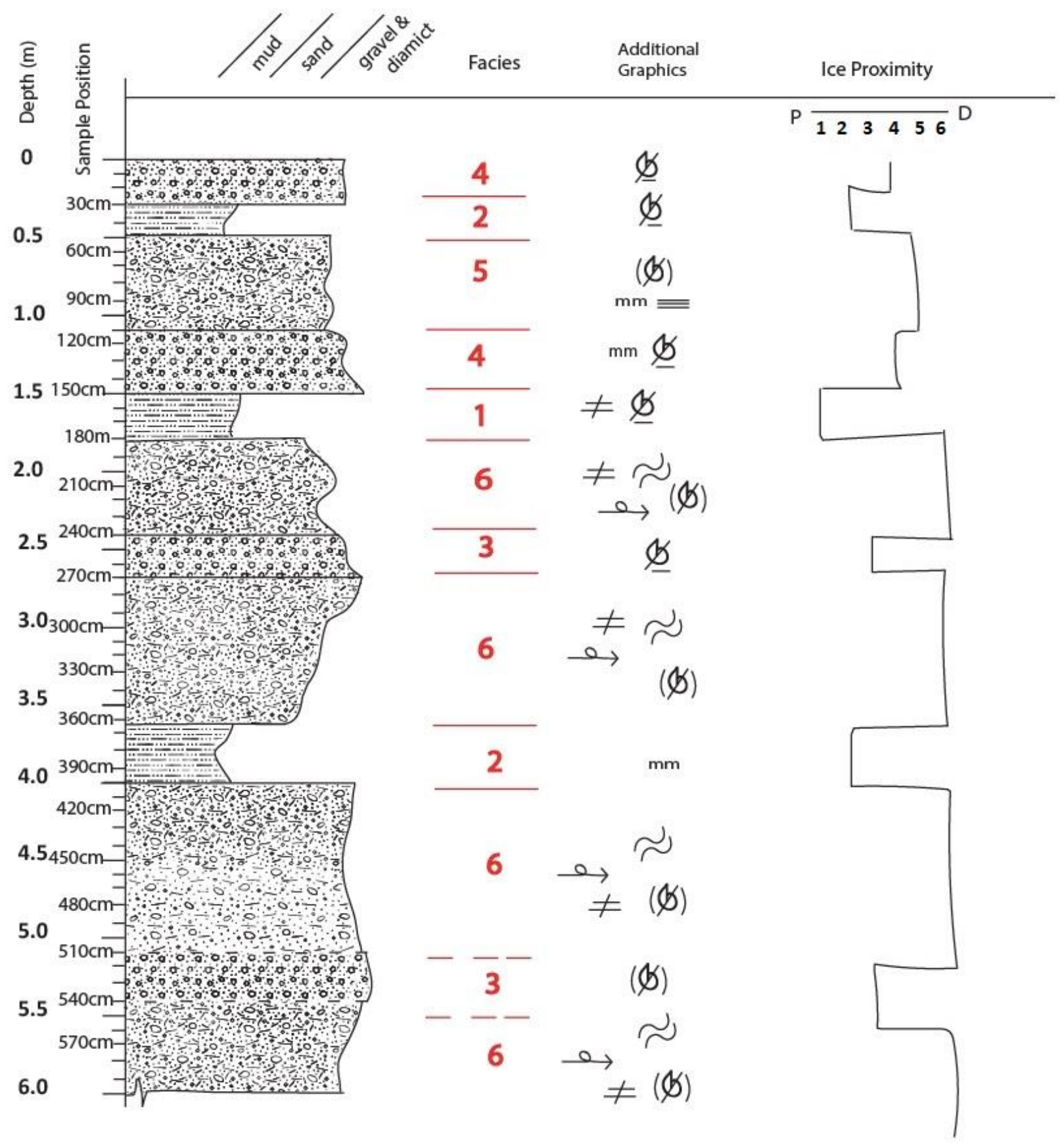

Figure 4.2: DO3A lithologic log. Ice proximity curve inferred from a combination of sediment texture, lithofacies analysis, and faunal content of each facies. Facies number and nature of contact indicated in red, dashed line indicates gradational but otherwise contacts are sharp. Refer to legend on page 59 for explanation of additional graphics. 


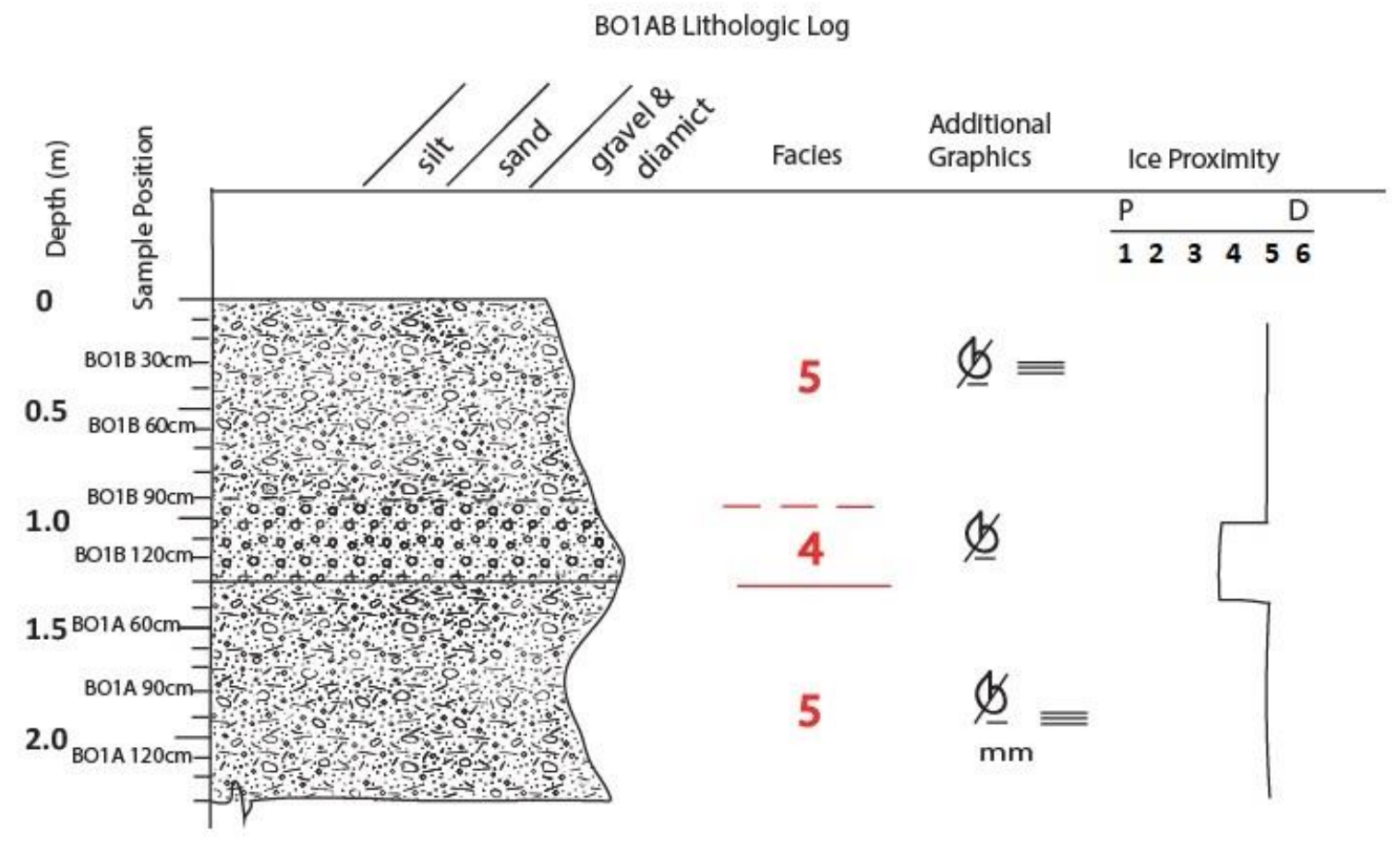

Figure 4.3: $\mathrm{BO} 1 \mathrm{AB}$ composite lithologic log. Ice proximity curve inferred from a combination of sediment texture, lithofacies analysis, and faunal content of each facies. Facies number and nature of contact indicated in red, dashed line indicates gradational but otherwise contacts are sharp. Refer to legend for explanation of additional graphics.

Legend

Mudstone broken shell fragments

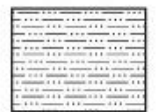

rare (ф)

abundant $\not$

Conglomerate

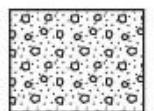

convalute

clast alignment $\stackrel{0}{\longrightarrow}$

Diamictite

laminations $\mathrm{mm}$

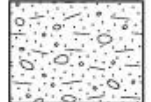

stratified $\equiv$

massive $\neq$ 


\subsection{Lithofacies analysis}

\begin{tabular}{|c|c|c|c|c|}
\hline $\begin{array}{l}\text { Facies } \\
\text { number }\end{array}$ & Simplified Description & Inferred depositional process & $\begin{array}{l}\text { Total } \\
\text { thickness } \\
\text { (cm) }\end{array}$ & $\begin{array}{l}\text { Proportion } \\
\text { (\%) }\end{array}$ \\
\hline 1 & Massive sandy mudstone & $\begin{array}{l}\text { Hemipelagic settling in an ice-distal glacimarine } \\
\text { environment with with some tide-water glacier } \\
\text { plume sedimentation and minor iceberg rafting }\end{array}$ & 70 & 5.59 \\
\hline 2 & $\begin{array}{l}\text { Sandy mudstone with dispersed } \\
\text { clasts }\end{array}$ & $\begin{array}{l}\text { Hemipelagic settling in an ice-distal to ice-proximal } \\
\text { glacimarine setting with increased influence of } \\
\text { iceberg rafting and meltwater plume sedimentation }\end{array}$ & 92 & 7.35 \\
\hline 3 & Clast-supported conglomerate & $\begin{array}{l}\text { Sediment-laden proglacial and subglacial fluvi- } \\
\text { deltaic glacimarine meltwater discharge }\end{array}$ & 77 & 6.15 \\
\hline 4 & Matrix-supported conglomerate & $\begin{array}{c}\text { Highly sediment-charged proglacial meltwater } \\
\text { plumes }\end{array}$ & 351 & 28.04 \\
\hline 5 & Stratified diamictite & $\begin{array}{l}\text { Grounding-line proximal glacimarine fans and } \\
\text { wedges, ice rafting, and sediment gravity flow re- } \\
\text { deposition }\end{array}$ & 332 & 26.52 \\
\hline 6 & Massive diamictite & $\begin{array}{c}\text { Subglacial deposition, some proximal glacimarine ice } \\
\text { rafting / re-deposition }\end{array}$ & 330 & 26.36 \\
\hline
\end{tabular}

Table 4.4: Summarised table of the glacimarine facies identified throughout DO1A/3A and BO1AB. Full grain size data is available in Appendix A.

\subsubsection{Facies 1: Massive sandy mudstone}

Facies 1 (Fig. 4.5) consists of light-medium grey/brown, friable, sandy mudstones. Facies 1 exhibits no observable laminations, nor any internal stratification/bedding features, and is considered massive. Extraformational clasts are rare ( 1\%) (Fig. 4.14), but when clasts do occur they are predominantly sub-rounded to angular, $<10 \mathrm{~mm}$ in diameter, and composed of a range of plutonic igneous (granite, gabbro, dolerite, diorite) and metasedimentary (quartzite, marble) lithologies. Clasts are not concentrated and display no preferred orientation nor alignment. Shell material is abundant and predominantly consists of disarticulated barnacle fragments belonging to the circum-Antarctic cirripede species Bathylasma corolliforme. Facies 1 have sharp basal contacts and are underlain by either conglomerate and diamictite facies. 


\section{Inferred depositional environment}

The dominant mudstone lithology of Facies 1, with low sand content (Figs. 4.11; 4.12) and rare extraformational clasts (Fig. 4.14), indicates a depositional environment that is under the influence of hemipelagic suspension settling. The addition of minor amounts of gravel and coarse sand is thought to reflect the contribution of ice rafting (Fielding et al., 2000; Krissek et al., 2007; McKay et al., 2009). The low IRD content (Fig. 4.14) and fine-grained nature (Figs. $4.11 ; 4.12$ ) of Facies 1 is typical of a low energy, ice-distal environment (Eyles and Eyles, 1992; Dowdeswell et al., 1998; Fielding et al., 2000; Ó Cofaigh and Dowdeswell, 2001). These earlier high-latitude studies attribute fine-grained sediment to meltwater plumes originating from the ice front (Elverhøi et al., 1980; Eyles and Eyles, 1992; Dowdeswell et al., 1998; Evans et al., 2002). Higher sedimentation rates closer to the grounding line inhibit a thriving community of benthic organisms, and as such massive mudstones have been interpreted as representing the most ice distal environments (Eyles and Eyles, 1992; Dowdeswell et al., 1998; Fielding et al., 2000; Ó Cofaigh and Dowdeswell, 2001; McKay et al, 2009).

An alternative explanation for mudstones that lack extraformational clasts is that they represent deposition beneath sediment-poor shore-fast sea ice (Ó Cofaigh and Dowdeswell, 2001). Silty claystones that are low in IRD have also been associated with deposition below an ice shelf carrying little/no subglacial debris in a polar glacial regime but at a greater distance from any basal debris (Domack et al., 1999; McKay et al., 2008). Howver the occurrence of common barnacles and open ocean planktic forams suggests that the most likely scenario for Facies 1 is that it represents hemipelagic settling in an ice-distal glacimarine environment with with some tide-water glacier plume sedimentation and minor iceberg rafting.

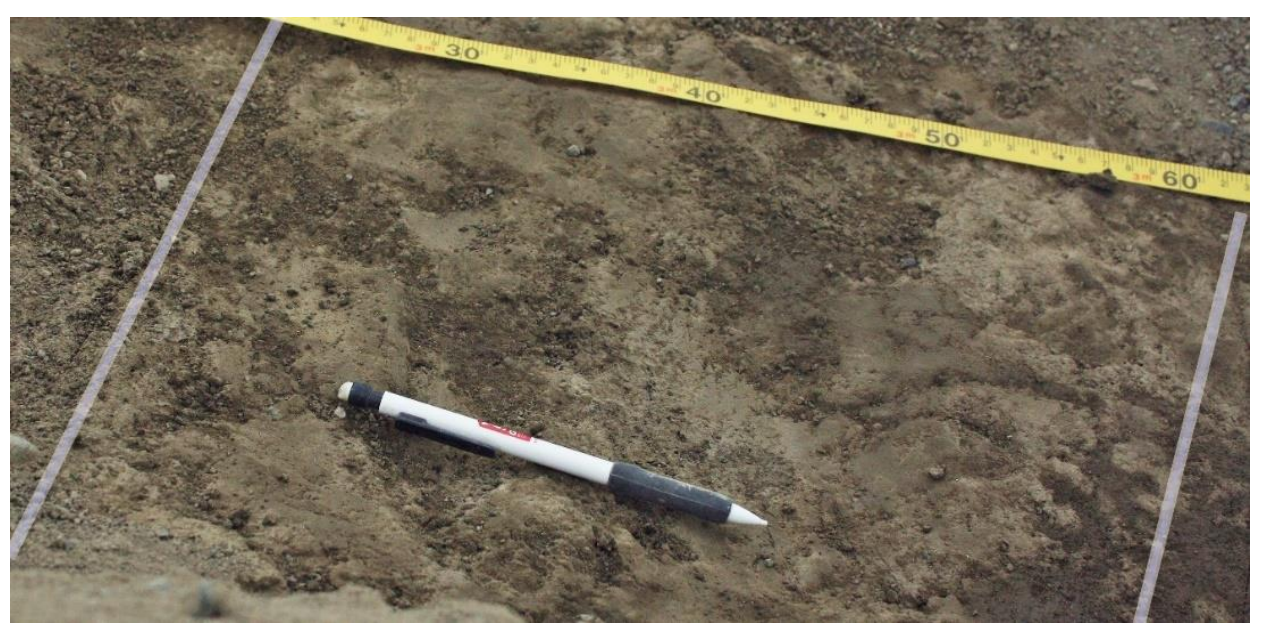

Figure 4.5: Facies 1: Massive sandy mudstone. Note the absence of extraformational clasts or any sedimentological features. Grey line indicates a sharp basal contact with the matrixsupported conglomerate (Facies 4) below and sharp contact with the overlying clastsupported conglomerate 


\subsubsection{Facies 2: Sandy mudstone with dispersed clasts}

Facies 2 (Fig. 4.6) is composed of light yellow-brown, friable, sandy mudstones which contain common clasts ( 4\%) (Fig. 4.14). As with Facies 1, clasts in Facies 2 are no larger than 10 $\mathrm{mm}$ in diameter, and consist of a range of igneous (granite, gabbro, dolerite) and metasedimentary (quartzite, marble) lithologies. Clasts are sub-rounded to angular, display no preferred orientation, nor any particular alignment, and are not observed in any concentrations. Facies 2 exhibits weak horizonal laminations and convolute deformation features that are defined on the basis of changes in matrix grainsize. Broken shell fragments are abundant, and again these are dominated by remains of the circum-Antarctic cirripede Bathylasma corolliforme. as well as rare broken shell fragments and randomly dispersed basalt clasts of granule-pebble size. Facies 2 typically occurs in sequence overlying stratified diamictite facies, separated by an abrupt/sharp basal contact.

\section{Inferred depositional environment}

Facies 2 is again thought to reflect deposition in a proglacial-grounding line marine environment that is under the influence of hemipelagic sedimentation (Dowdeswell et al., 1998; Powell et al., 2000; Ó Cofaigh and Dowdeswell, 2001; Fielding et al., 2000; Powell et al., 2000; McKay et al, 2009). Although the IRD content of Facies 2 is still minor, its increase relative to Facies 1 represents deposition closer to the ice margin (Figs. 4.11; 4.12; 4.13) (Fielding et al., 2000; Powell et al., 2000; Evans et al., 2002; Krissek et al., 2007; McKay et al., 2009). Greater amounts of IRD in mudstone facies have been previously associated with deposition during an advance or retreat of a marine-terminating ice margin (Dowdeswell et al., 1998). However, increased IRD content does not always denote closer proximity to the ice front. The amount of IRD in a deposit can vary depending on a range of factors, including but not limited to the debris content of the depositing ice, water temperatures, drift patterns of icebergs, the type of glacier front, and the basal condition of the ice mass which calved the floating ice (i.e. frozen, melting, or freezing) (Ó Cofaigh and Dowdeswell, 2001).

Previous studies of high-latitude glacimarine sediments have interpreted laminations in finegrained mudstones as a sign of bottom currents, suspension settling of turbid plumes, or submarine outwash winnowing finer material, which suggests the presence of subglacial meltwater (Ó Cofaigh et al., 2001; Fielding et al., 2000; Powell et al., 2000; Krissek et al., 2007). Laminations in ice proximal sediments are also thought to reflect significant volumes of subglacial meltwater being discharged from the ice front, implying a polythermal or warm- 
based glacial regime (Ó Cofaigh and Dowdeswell, 2001). However, this does not necessarily indicate a temperate glacial regime as the base of a glacier can be at the pressure melting point in subpolar glacial regimes (Ó Cofaigh and Dowdeswell, 2001). The preferred interpretation for deposition of Facies 2 is that of hemipelagic sedimentation in a marine environment that is more proximal to the ice margin than Facies 1. Although higher amounts of IRD is not always associated with increased proximity to the grounding line, this study attributes greater silt/sand and gravel content (Figs. 5.12-5.13; 5.15) to deposition in a more turbid/energetic environment that is closer to the ice front where finer material is unable to settle out.

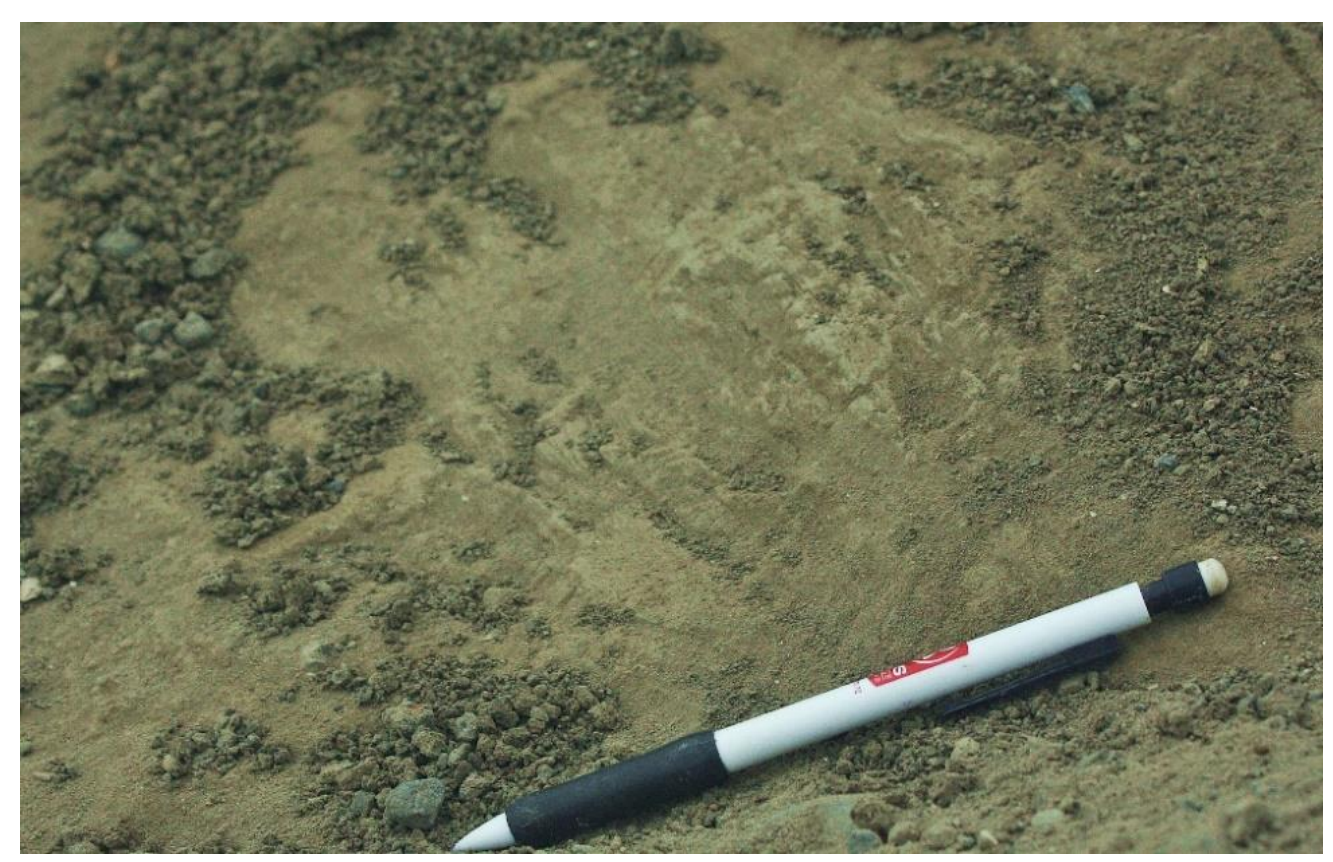

Figure 4.6: Facies 2: Sandy mudstone with dispersed to common clasts. Facies 2 is distinguishable from Facies 1 on the basis of increased IRD content and laminations.

\subsubsection{Facies 3 and 4: Clast- and matrix-supported conglomerate}

Facies 3 and 4 (Figs. 4.7 and 4.8) consist of clast- and matrix-supported conglomerates. Clasts are sub-rounded to angular, and are poorly sorted. Some clasts exhibit striations, but generally clasts are pebble to cobble grade, and are composed of various igneous and metasedimentary lithologies. Sediments are locally oxidised, and broken shell material, including fragments of Bathylasma corolliforme, are common. These conglomerates are poorly sorted with localised oxidation and concentrations of marine shell fragments. Facies 3 and 4 most commonly have 
sharp basal contacts with the diamictite facies below, but in some cases the underlying/overlying diamictites pass gradationally into conglomerate facies. Facies 3 and 4 are also sharply overlain in sequence DO1A/3A by fine-grained mudstone (Facies 1 and 2) which represent the most ice-distal depositional environments.

\section{Inferred depositional environments}

The bedding relationship between conglomerate Facies 3/4 and diamictite Facies 5/6 has been used in in the past to infer a depositional environment that is proximal to a marine-terminating ice margin (Lønne, 1995; Fielding et al., 2000). Better sorting and a more rounded nature of clasts is thought to reflect the influence of transport by currents, wave action, and/or hydraulic sorting (Lønne, 1995; Fielding et al., 2000; Powell et al., 2000; Krissek et al., 2007; McKay et al., 2009). It has been suggested that clast- and matrix-supported conglomerates indicate deposition in shallow marine settings proximal to subglacial or glaciodeltaic discharge points, where sediment-laden meltwater plumes are derived (Lønne, 1995; Fielding et al., 2000; Powell et al., 2000; Krissek et al., 2007; McKay et al., 2009).

Alternatively, it has been suggested that conglomerate facies indicate the winnowing of finer material from diamictite facies. However, the preferred interpretation for Facies 3 and 4 is that the conglomerates are derived from sub-glacial or potentially pro-glacial fluvial sedimentcharged glacial meltwater in an ice-proximal shallow marine environment. Highly sedimentladen flows are thought to be responsible for increases in sand-dominated matrix material (Figs. 4.7; 4.8) (Lønne, 1995; Fielding et al., 2000; Powell et al., 2000; Krissek et al., 2007; McKay et al., 2009). Additional sediment may be attributed to suspension rainout from floating ice. 

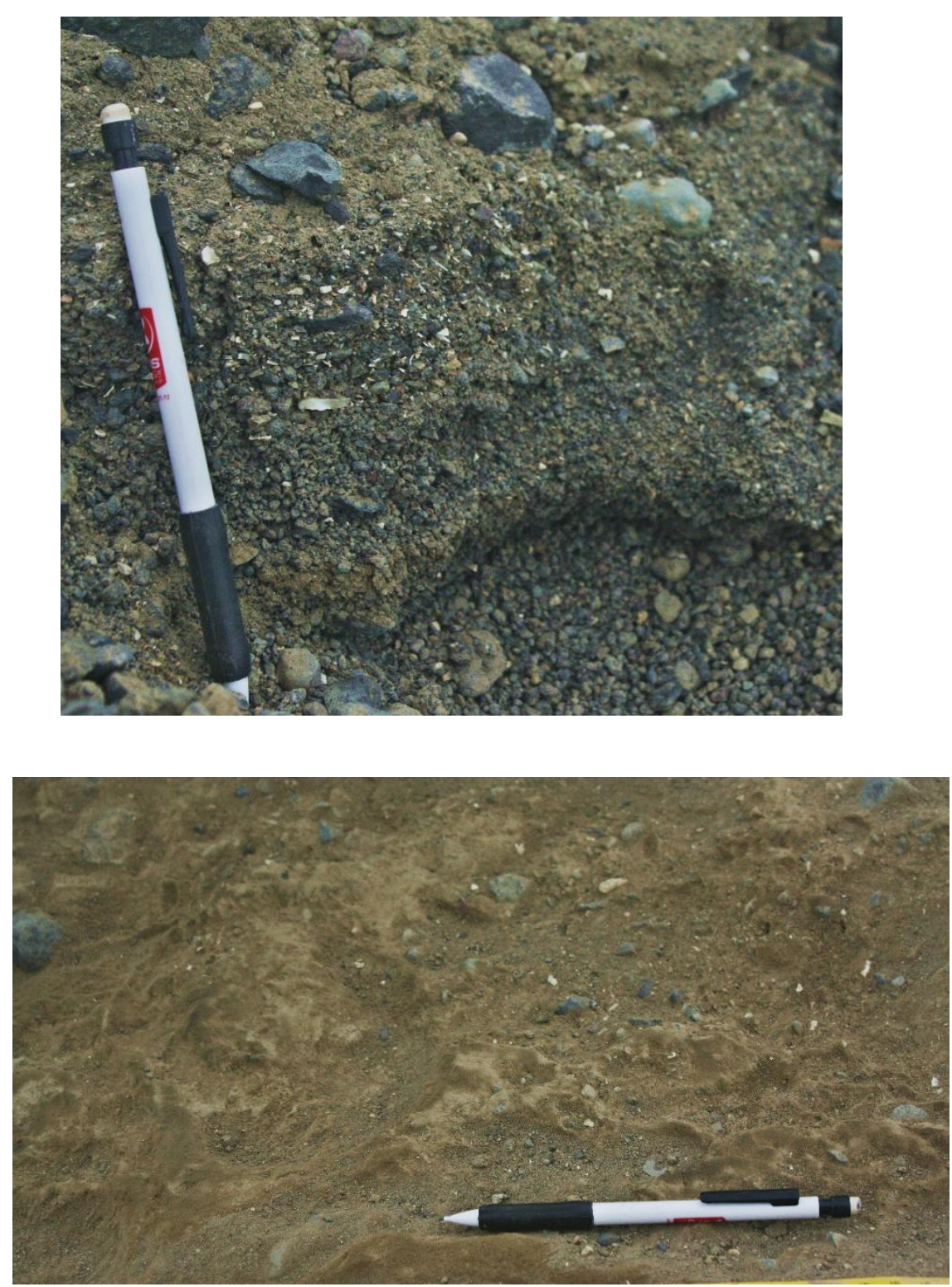

Figure 4.7: Top: Facies 3 clastsupported conglomerate, Fig. 4.8 Bottom: matrix-supported conglomerate Facies 4. Highly sediment-charged sub-glacial and proglacial fluvial discharge is thought to be responsible for increases in clast concentration and sand-dominated matrix material.

\subsubsection{Facies Five - Stratified Diamictite}

Facies 5 (Fig. 4.9) is composed of light grey-brown, sandy/muddy diamictites that vary from clast-poor to clast-rich, with areas of locally higher clast concentrations. Stratification is defined on the basis of decreasing clast concentration and changes in matrix grainsize (i.e. muddy to sandy) (Figs. 4.11; 4.12; 4.13). Clasts are sub-rounded to angular, pebble to cobble grade in size, and display some striations. Various igneous and metasedimentary lithologies are present, but clasts do not appear to be oriented in any preferred fashion. Facies 5 is weakly laminated, and sediment intrusion structures/convolute deformation features are characterised based on changes in matrix grainsize. Shell material is rare, but when present fragments predominantly consist of Bathylasma corolliforme. Facies 5 can be found sharply overlain by, or passing gradationally into, conglomerate Facies 3 and 4. 


\section{Inferred depositional environments}

Stratified diamictites are generally regarded as an indication of deposition in a turbid, ice proximal environment (Krissek et al., 2007; McKay et al., 2009). High sedimentation rates this close to the grounding line prevent fauna from thriving, resulting in a lack of in-situ macrofauna and bioturbation (Eyles and Eyles, 1992; Ó Cofaigh and Dowdeswell, 2001; Benn and Evans, 2010). Stratification is often thought to originate from the winnowing of fine material by traction currents, which may produce characteristic cross bedding and a sandier matrix. Laminations of silt, clay and fine sand, however, may indicate plumes of sediment-laden meltwater discharging from the ice front (Powell et al., 2000; Fielding et al., 2000; Ó Cofaigh and Dowdeswell, 2001; Krissek et al., 2007; McKay et al., 2009). Convolute deformation has been associated in these previous studies to individual or stacked mass flow deposits derived from re-sedimentation of unstable deposits near the marine ice terminus (Powell et al., 2000; Fielding et al., 2000; Ó Cofaigh and Dowdeswell, 2001; Krissek et al., 2007; McKay et al., 2009). Additionally, gradational contacts and random orientation of clasts is thought to reflect fall sorting by currents during the rainout of IRD (Eyles and Eyles, 1992; Domack et al., 1999; Powell et al., 2000; Fielding et al., 2000; Ó Cofaigh et al., 2001). Finer stratification may also imply a greater contribution of meltwater (Powell et al., 2000; Fielding et al., 2000; Ó Cofaigh et al., 2001).

Stratified diamictites are less commonly associated with subglacial deposition compared to massive diamictites (Fielding et al., 2000; Krissek et al., 2007; McKay et al., 2009). The preferred interpretation for Facies 5 is that it was deposited very proximal to the ice front in a shallow marine setting, but not subglacially. The sharp/gradational transition from Facies 5 into conglomerate Facies 3 and 4 represents the appearance of fluvio-deltaic deposition or debris flows in the grounding zone wedge as the glacier grounding line begins to retreat (Fielding et al., 2000; Ó Cofaigh and Dowdeswell, 2001; Krissek et al., 2007; McKay et al., 2009). 


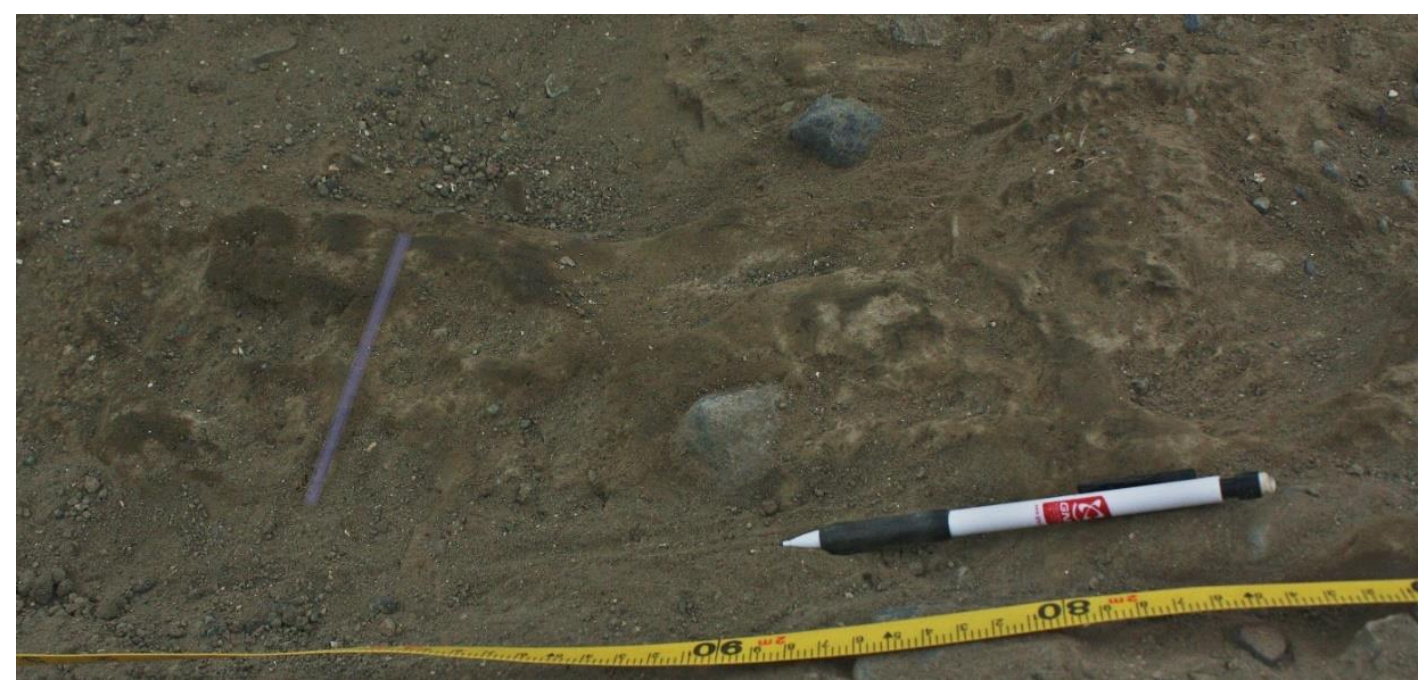

Figure 4.9: Facies 5: Stratified diamictite. Note the sharp basal transition from Facies 5 into conglomerate Facies 3, representing the appearance of fluvio-deltaic deposition or debris flows in the grounding zone wedge as the glacier grounding line begins to retreat (Fielding et al., 2000; Ó Cofaigh and Dowdeswell, 2001; Krissek et al., 2007; McKay et al., 2009).

\subsubsection{Facies Six - Massive Diamictite}

Facies Six (Fig. 4.10) consists of massive, clast-rich to clast-poor, sandy/muddy diamictites that display no internal stratification/bedding features. Clasts are sub-rounded to angular, pebble to cobble grade, and generally display no preferred orientation, although some apparent clast alignment is observed. A range of igneous and metasedimentary lithologies are included, and some clasts are striated. Shell fragments are rare, but when present they are again dominated by remains of Bathylasma corolliforme, and can be found in concentrated lenses of shell hash.

\section{Inferred depositional environments}

Massive diamictites are associated with a range of depositional environments, but as with Facies 5 they are generally indicative of deposition in an energetic, ice-proximal setting (Krissek et al., 2007; McKay et al., 2009). Characteristic features of massive diamictites that suggest deposition beneath grounded ice include but are not limited to sharp basal contacts, a lack of bioturbation, load injection structures, alignment of clasts, discontinuous units, folds, shear planes, broken fauna, and rip-up clasts (Hart and Roberts, 1994; Domack et al., 1999; Ó Cofaigh and Dowdeswell, 2001; Krissek et al., 2007; McKay et al., 2009). A fining upward trend in massive diamictites that are bounded by sharp basal contacts may also suggest deposition via more debris flow resulting from oversteepening near the ice front (Elverhøi et al., 1983; Dowdeswell et al., 1998; Hambrey et al., 1991; Eyles and Eyles, 1992; Nam et al., 
1995; Powell et al., 2000; Ó Cofaigh et al., 2001; Evans et al., 2002; Krissek et al., 2007; McKay et al., 2009).

Alternatively, some studies have attributed massive diamictites with no clast alignment, and gradational upper and lower contacts, to deposition arising from the rainout of ice-rafted debris. In such cases gradational contacts are interpreted to reflect continued sedimentation (Eyles and Lagoe, 1990; Powell et al., 2000; Ó Cofaigh et al., 2001; Evans et al., 2002; Krissek et al., 2007; McKay et al., 2008). Conversely, in an environment where ice shelves are present, calving icebergs typically contain little debris as the majority melts out close to the grounding line. Massive diamictites in such an environment are more likely to be deposited proximal to the grounding line (Anderson et al., 1983; Powell et al., 1984; Anderson et al., 1991; Hambrey et al., 1991; Ó Cofaigh and Dowdeswell, 2001; McKay et al., 2008).

The most likely explanation for the massive diamictites Facies 6 is that deposition occurred either subglacially, or in very close proximity to, the grounding line. It is not implausible to assume a primarily subglacial origin for Facies 6, given the evidence from previous studies outlined above. Sharp basal contacts, observed clast alignment, and a lack of bioturbation, are inferred to be indicators of deposition beneath grounded ice, although deposition proximal to the grounding line may still be possible. The interpretation that massive diamictites such as Facies 6 are deposited via rainout of IRD is rejected in this instance as Facies 6 is not found to occur in association with distal muds of Facies 1 and 2, but rather grades up into ice proximal glaciamrine conglomerate facies 3 and 4 .

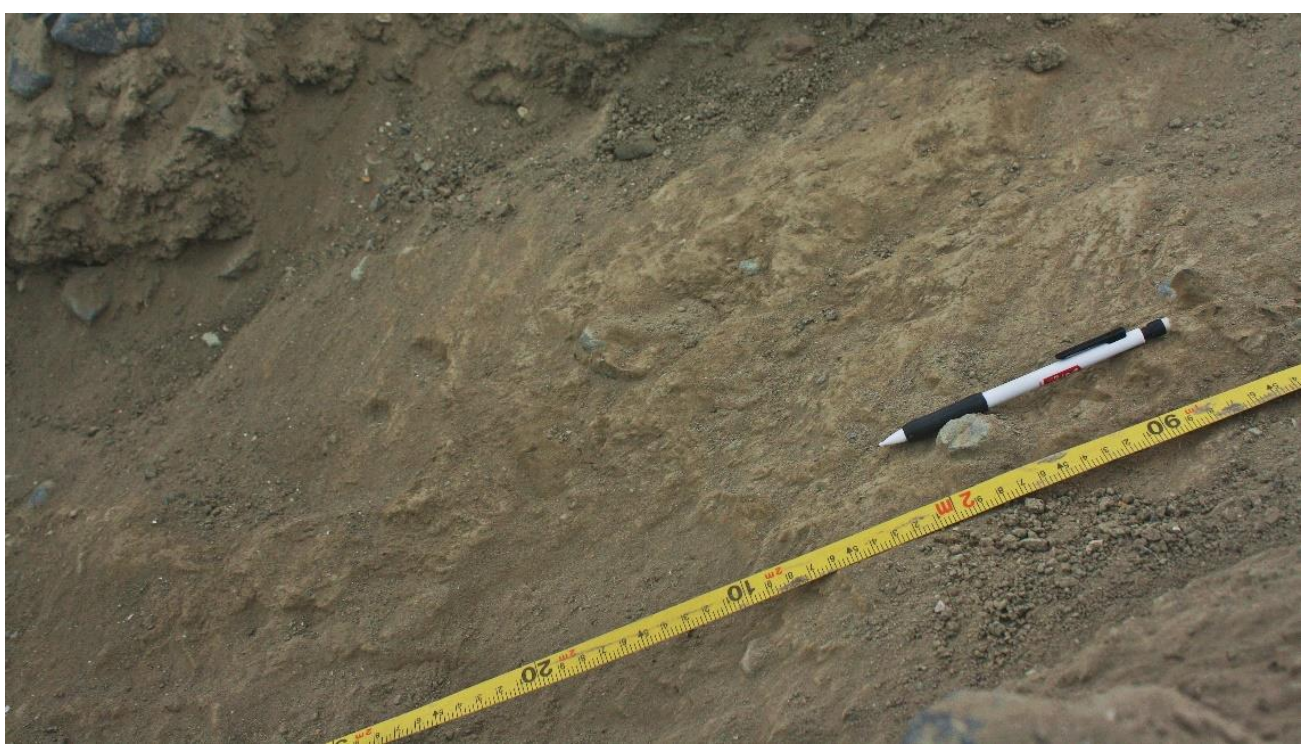

Figure 4.10: Massive diamictite Facies 6. Sharp basal contacts, observed clast alignment, and a lack of bioturbation, are inferred to be indicators of deposition beneath grounded ice, although deposition proximal to the grounding line may still be possible (Elverhøi et al., 1983; Dowdeswell et al., 1998; Hambrey et al., 1991; Eyles and Eyles, 1992; Nam et al., 1995; Powell et al., 2000; Ó Cofaigh et al., 2001; Evans et al., 2002; Krissek et al., 2007; McKay et al., 2009). 

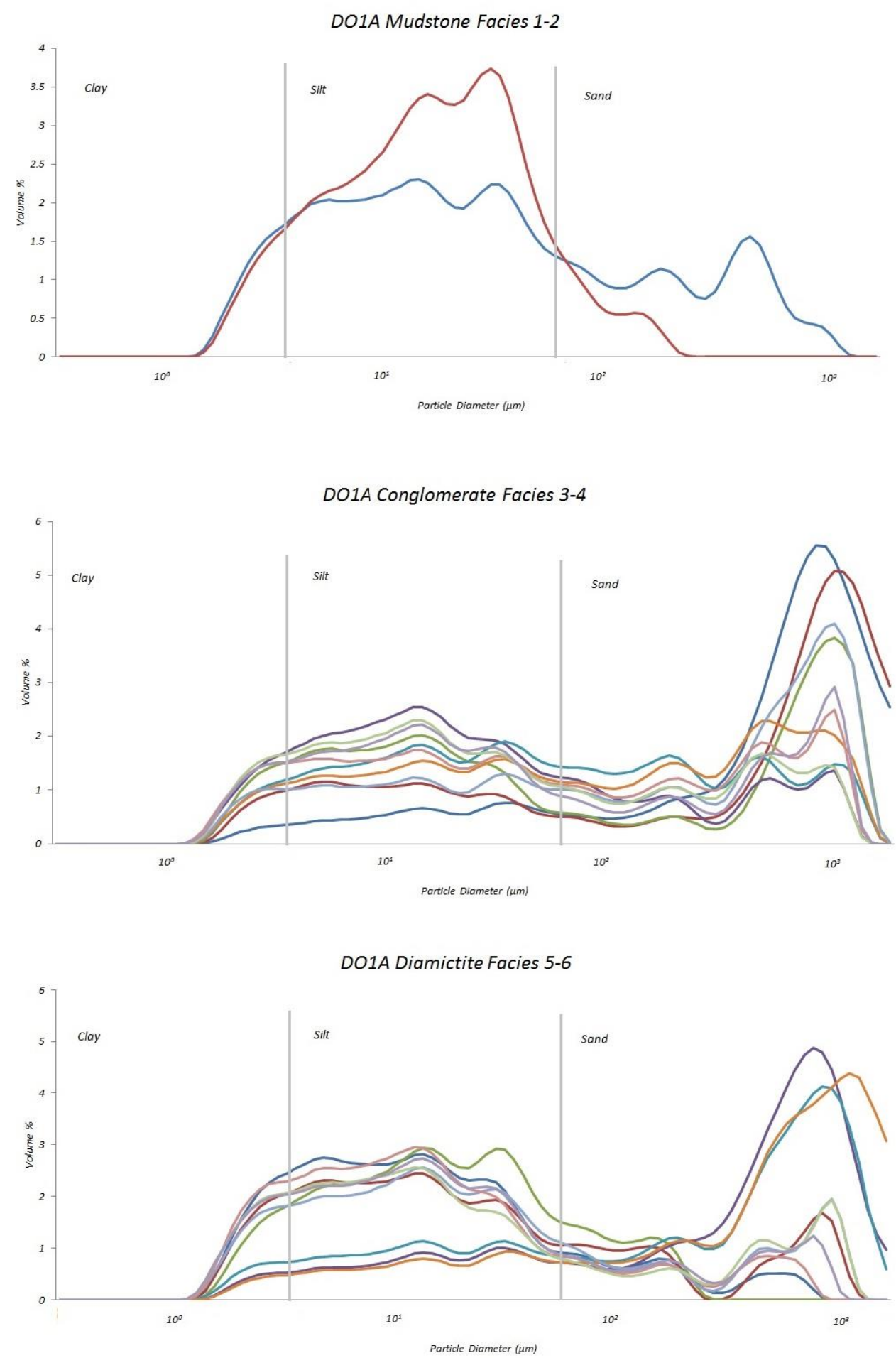

Figure 4.11: Grainsize distributions of the fine fraction from DO1A Facies 1-6. Grey bars indicate clay/silt and silt/sand boundaries. Grainsize data available in Appendix A. 


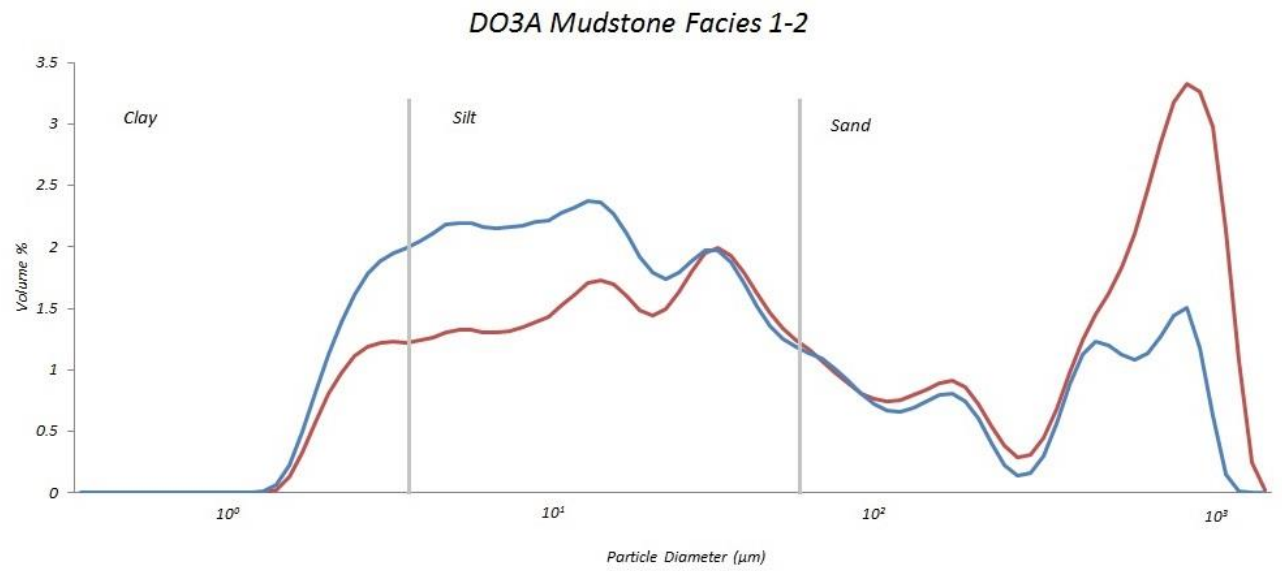

DO3A Conglomerate Facies 3-4

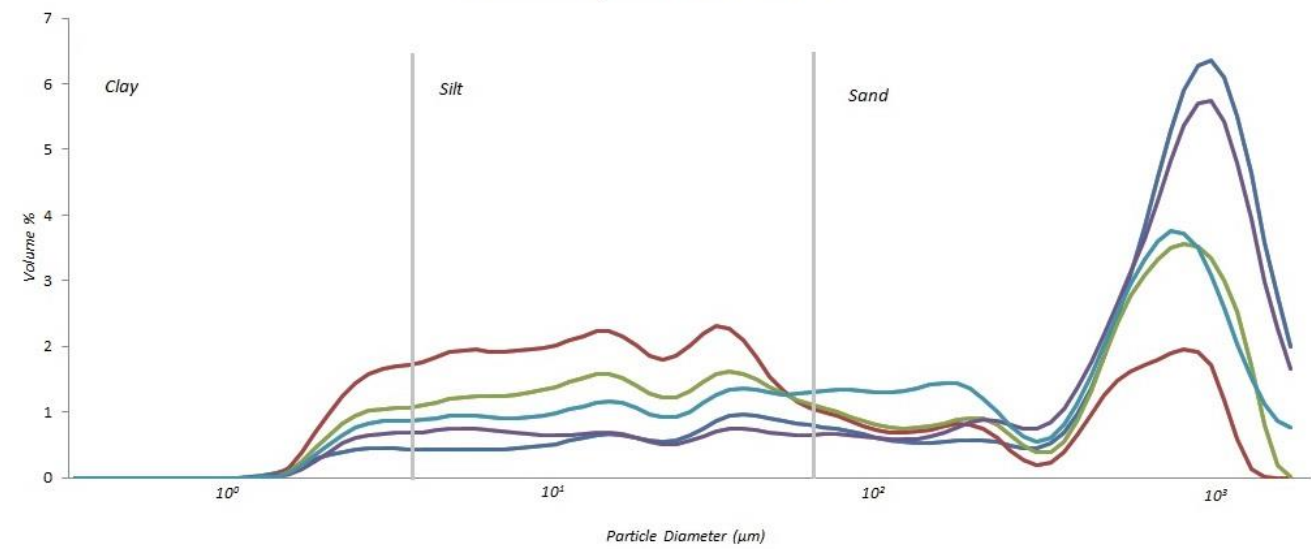

DO3A Diamictite Facies 5-6

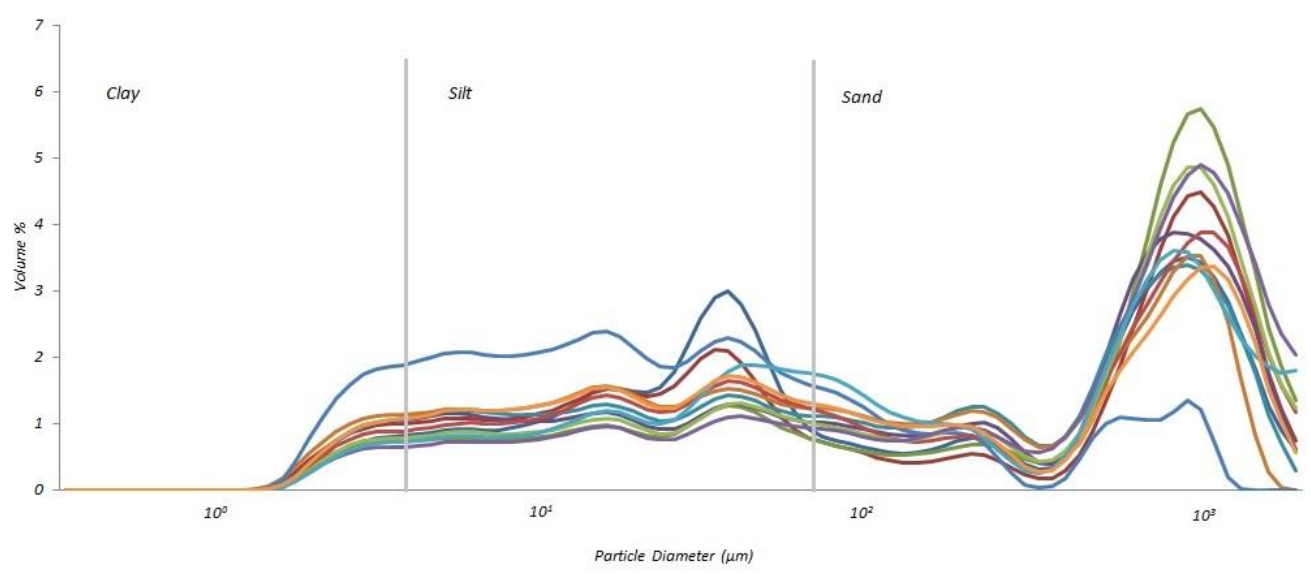

Figure 4.12: Grainsize distributions of the fine fraction from DO3A Facies 1-6. Grey bars indicate clay/silt and silt/sand boundaries. Grainsize data available in Appendix A 

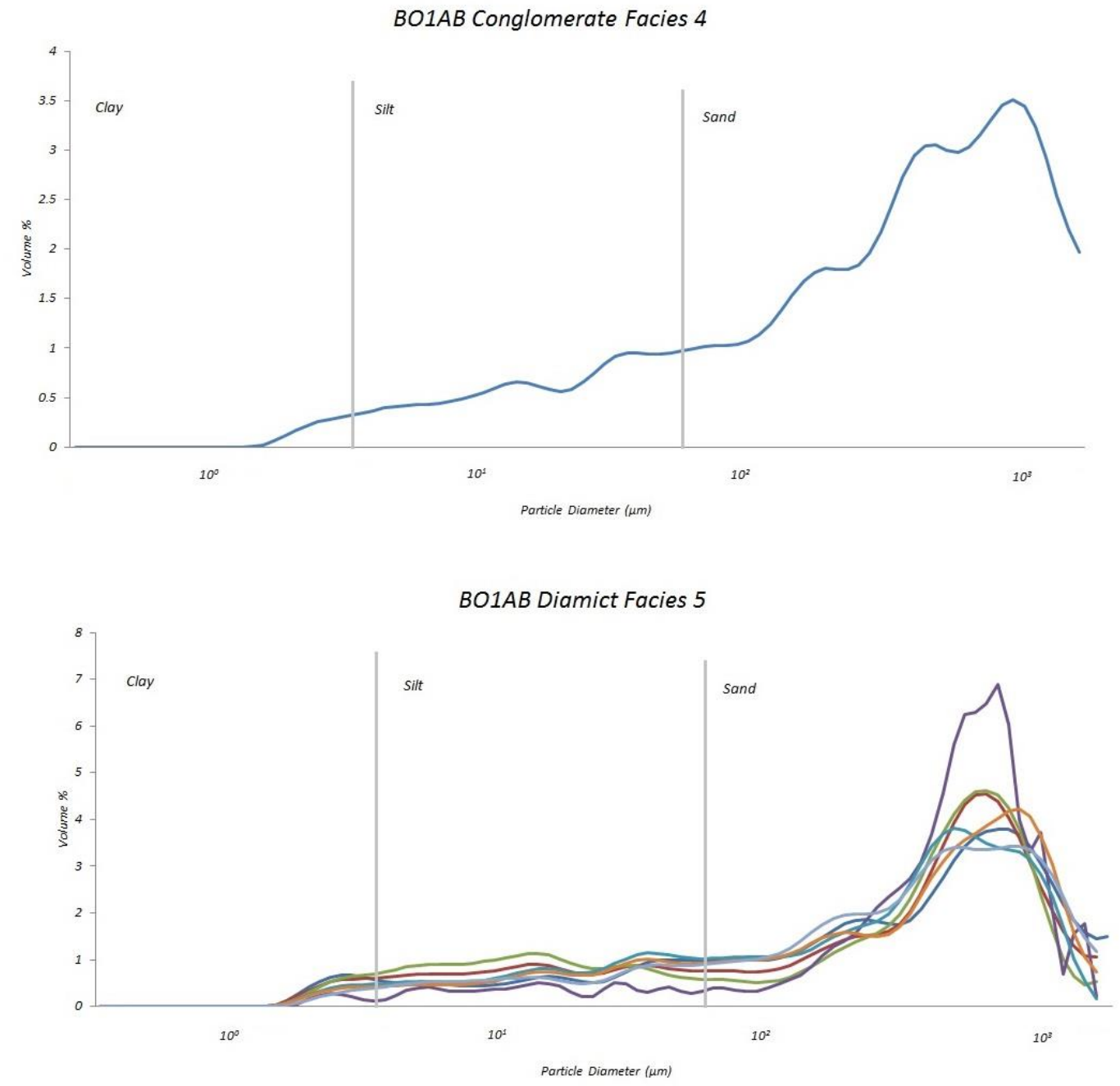

Figure 4.13: Grainsize distributions of the fine fraction from BO1AB Facies 4 and 5. Grey bars indicate clay/silt and silt/sand boundaries. Grainsize data available in Appendix A 

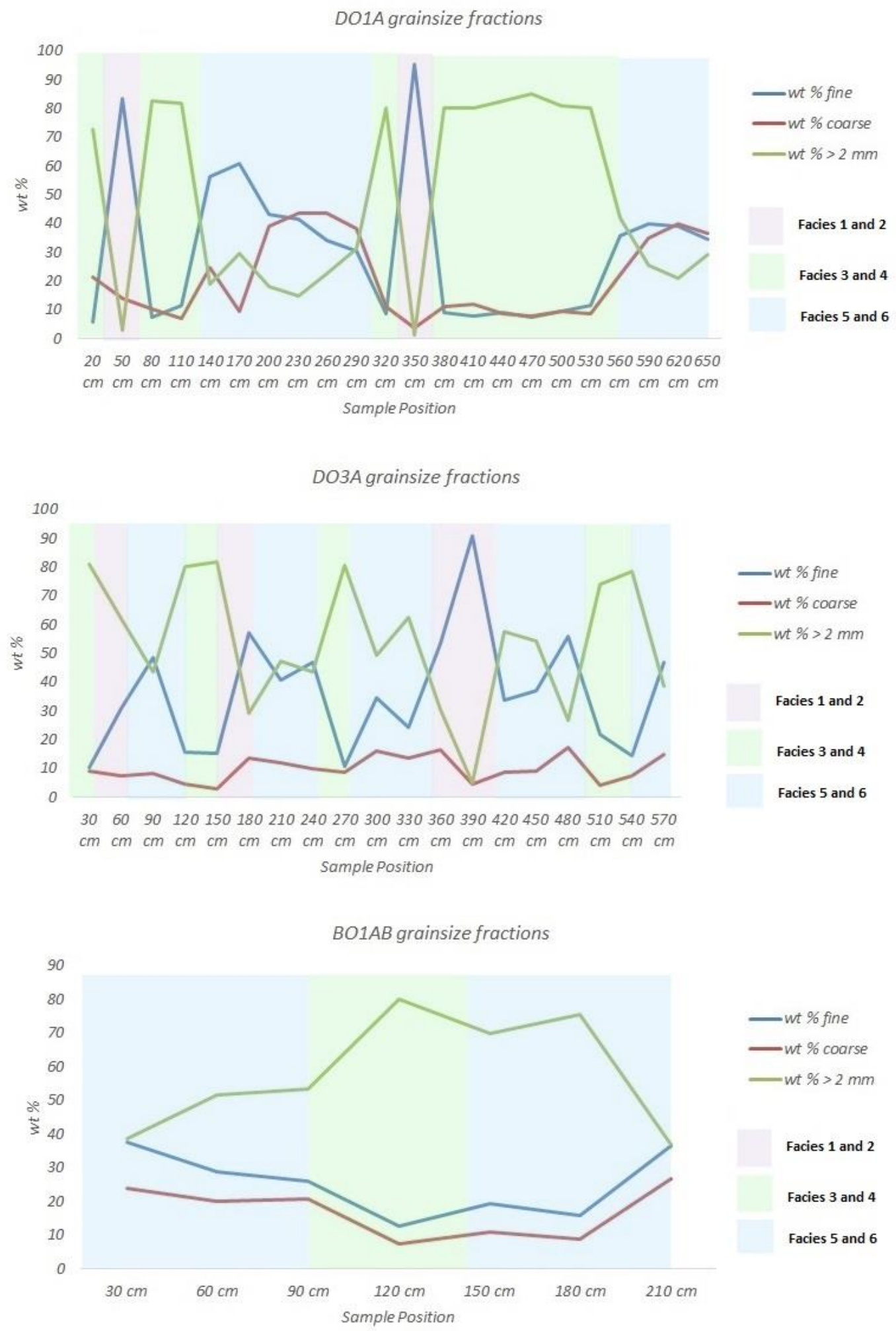

Figure 4.14: Grainsize fractions (wt \%). Data available in Appendix A. 


\subsection{Microfauna results}

Species abundance is highly variable throughout deposits $\mathrm{DO} 1 \mathrm{~A} / 3 \mathrm{~A}$ and $\mathrm{BO} 1 \mathrm{AB}$, and in general samples are low in both specimen numbers and species diversity. Foraminifera were identified from six lithologies that represent Facies 1 through 6, and these have been sorted according to taxonomy with assistance from Hugh Morgans, GNS Science. Re-crystallisation of calcite has not affected any foraminifera examined in this study, and specimens appear to have suffered very little diagenesis, suggesting taxa represent in-situ faunal assemblages. Overall, facies 1 through 6 are dominated by calcareous epifaunal benthic foraminfera with the most common species being Ehrenbergina glabra (Fig. 4.14), Trifarina pauperata, (Fig. 4.14), and Cibicides sp. The abundance of planktic foraminfera (Fig. 4.14) varies significantly across each lithofacies, while agglutinated taxa are completely absent. Foraminifera species identified in this study persist today in the oceanic region surrounding Antarctica and offer no age diagnostic information.
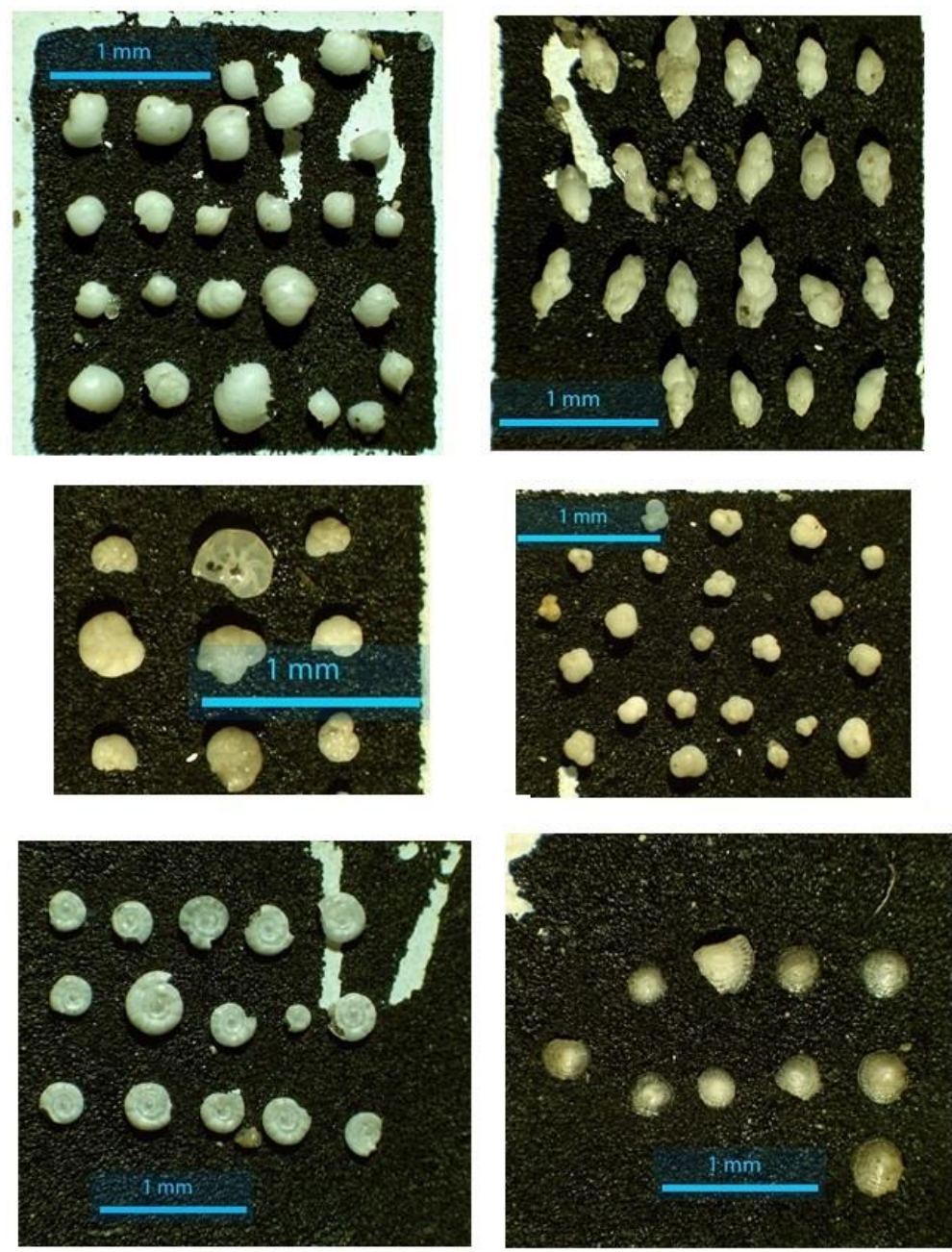

$\begin{array}{lcr}\text { Figure } & \text { 4.15: } & \text { Left-Right: } \\ \text { Ehrenbergina } & \text { glabra; } & \text { Trifarina } \\ \text { pauperata; } & \text { Lenticulina } & \text { gibba; }\end{array}$ Neogloboquadrina pachyderma; Cornuspiroides expansus; Patellina Antarctica. Specimens pictured are all from within Facies 1 (DO1A $350 \mathrm{~cm}$ ). 

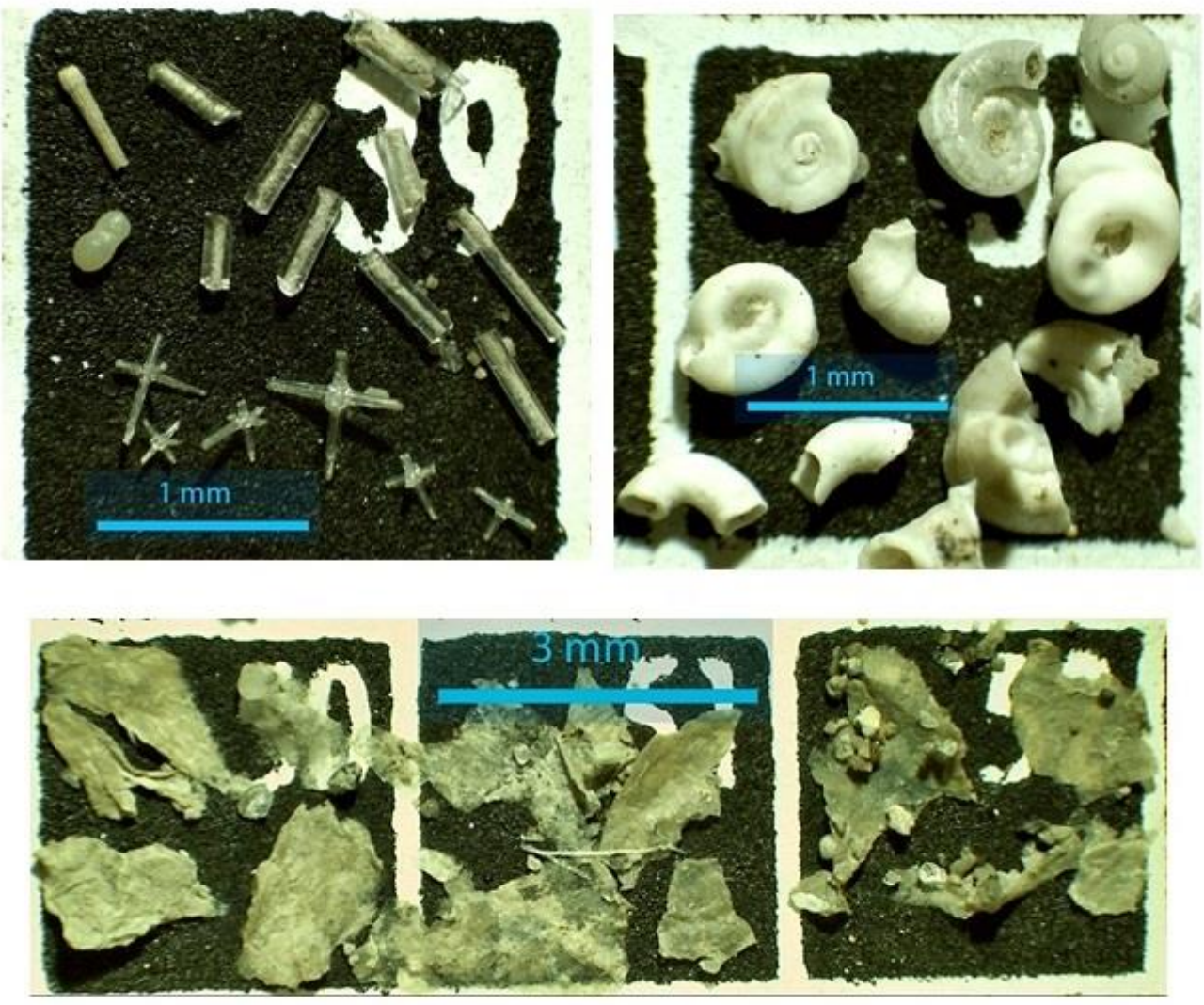

Figure: 4.16: Additional material recovered from microfauna samples includes sponge spicules, polychaete worm tubes, and unidentified algal material.

\subsubsection{Facies One, Massive Sandy Mudstone - Figs. 4.15; 4.16; 4.17}

A total of 234 specimens were recovered from DO1A $350 \mathrm{~cm}$ out of a sample weight of 4.24 grams. Facies 1 is most fossiliferous unit with 55 specimens per gram of sample. Lithofacies analysis indicates that this unit was deposited in an ice-distal open marine environment by hemipelagic settling under the influence of ice rafting. Ehrenbergina glabra is the most dominant species with 49 specimens recorded, followed by Lenticulina gibba, and Trifarina pauperata which each total over 20 specimens. The fourth most abundant species is the planktonic foraminifera Neogloboquadrina pachyderma, but other common species include Oolina hexagona, Cornuspiroides expansus, Quinqueloculina suborbicularis, Cibicides sp., and Patellina antarctica. Facies 1 records the highest percent planktic species at $8 \%$, determined by the total number of planktic specimens picked per sample. Facies 1 is also rich in fragments of Bathylasma corolliforme bryozoan colonies, sponge spicules, algae and serpulid polychaete tubes (Figs. 4.15). 


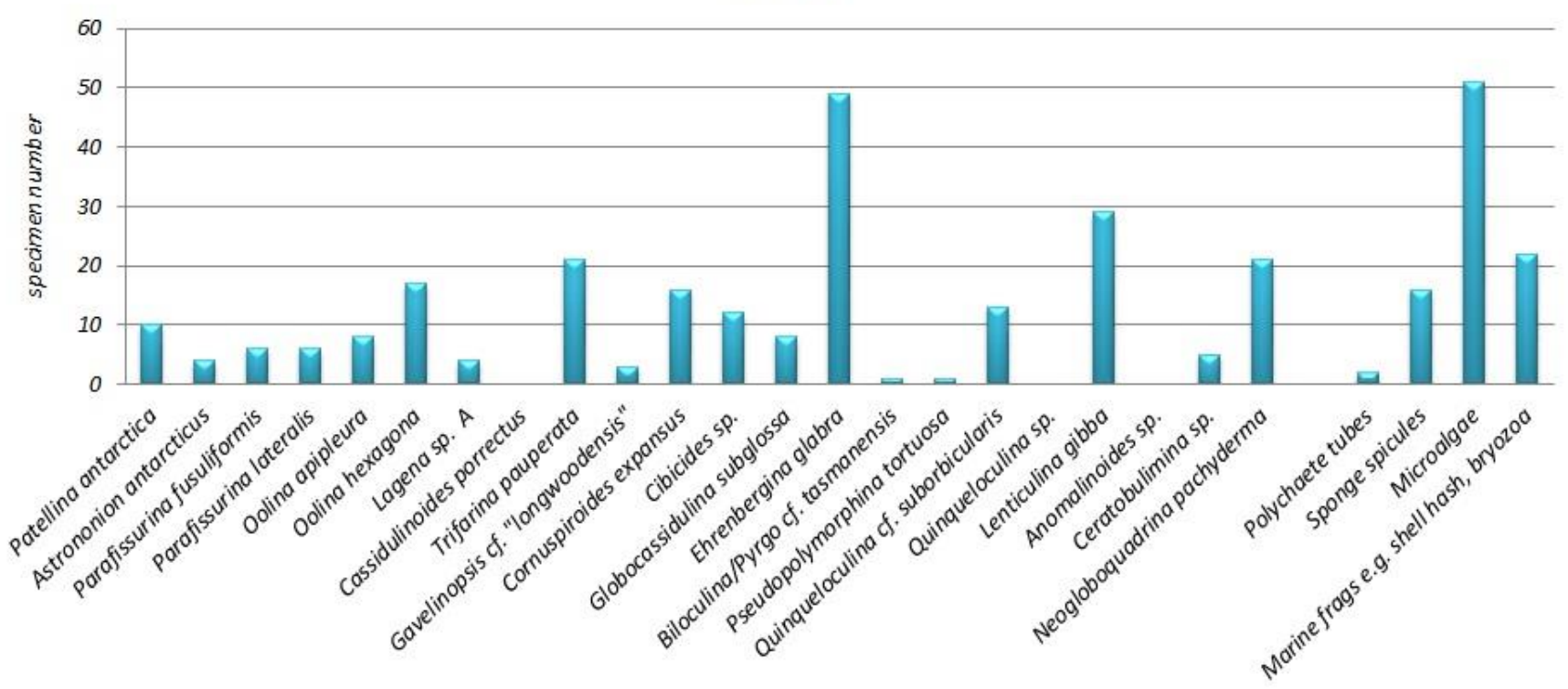

Figure 4.17: Foraminifera species and additional microfossils recovered from Facies 1; DO1A $350 \mathrm{~cm}$. Data available in Appendix B.

\subsubsection{Facies Two, Laminated Sandy Mudstone - Fig. 4.18}

Facies 2 is characterised by the second-highest percent planktic foraminifera (6\%), and second highest number of specimens per gram of sample (38). A total of 317 foraminifera were picked from DO3A $390 \mathrm{~cm}$ out of 8.34 grams of sample weight. Lithofacies results suggest deposition deposited via hemipelagic settling in an open marine, ice-proximal environment with a greater contribution of sedimentation from iceberg rafting. Cibicides sp., Ehrenbergina glabra, Trifarina pauperata, Lenticulina gibba, Quinqueloculina suborbicularis and Globocassidulina subglossa dominate Facies 2, along with other common species Patellina antarctica, Oolina apiopleura, Parafissurina lateralis, and Parafissurina fusiliformis. Facies 2 also contains what appears to be part of a crab claw, and is rich in sponge spicules, serpulid polychaete tubes, Bathylasma corolliforme, bryozoan colonies, and fragments of unidentified algal material. 


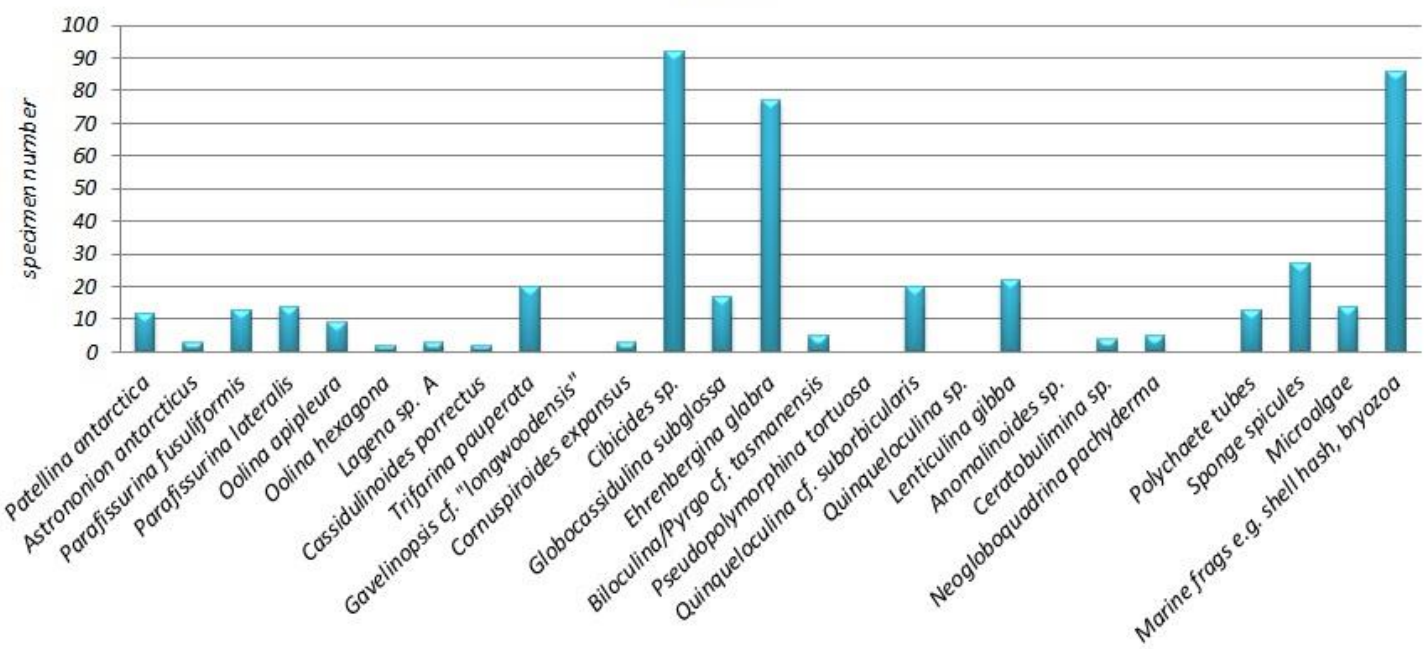

Figure 4.18: Foraminifera species and additional microfossils recovered from Facies 2; DO3A $390 \mathrm{~cm}$. Data available in Appendix B.

\subsubsection{Facies Three, Clast-Supported Conglomerate - Fig. 4.19}

Foraminifera identified in Facies 3 are again dominated by epifaunal benthic calcareous taxa Ehrenbergina glabra, Cibicides sp., Lenticulina gibba, Trifarina pauperata, Quinqueloculina suborbicularis, and Globocassidulina subglossa. Additional species present in smaller numbers include Oolina hexagona, Oolina apiopleura, Patellina antarctica, Astrononian antarcticus, and Ceratobulimina sp. Percent planktic foraminifera decreases in Facies 3 to $0.7 \%$, but a total of 269 foraminfera from 10.36 grams of sample makes Facies 4 still relatively fossiliferous with 26 specimens recovered per gram of sample. Minor amounts of serpulid polychaete tubes, Bathylasma corolliforme fragments, and sponge spicules, comprise the rest of fauna in Facies 3. Unlike Facies 1 and 2, Facies 3 contains no algal material.

Facies 3

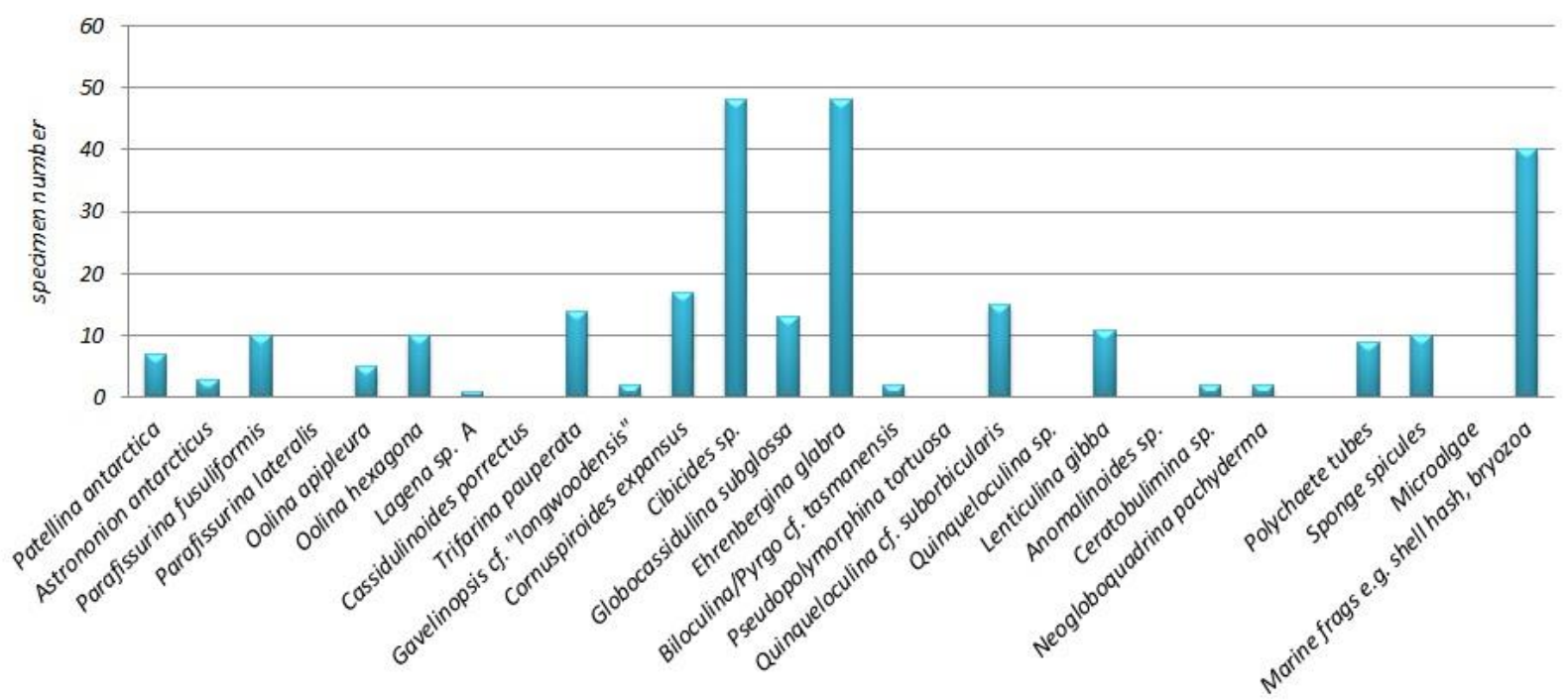

Figure 4.19: Foraminifera species and additional microfossils recovered from Facies 3; DO1A $320 \mathrm{~cm}$. Data available in Appendix B. 


\subsubsection{Facies Four, Matrix-Supported Conglomerate - Fig. 4.20}

Facies 4 mirrors the three previous facies whereby taxa are dominated by calcareous benthic species Ehrenbergina glabra, Cibicides sp., Lenticulina gibba, Trifarina pauperata, Quinqueloculina suborbicularis, Globocassidulina subglossa, and Parafissurina fusiliformis. Other common species include Pseudopolymorphina tortuosa, Patellina antarctica, and Astrononian antarcticus, as well as nine specimens of the planktic foraminifera Neogloboquadrina pachyderma. A total of 250 foraminfera were identified from 6.72 grams of sample, producing 37 specimens per gram of sample and $4 \%$ planktic species. Unlike the previous facies, minor amounts of algae material are present throughout Facies 4, along with sponge spicules, serpulid polychaete tubes, fragments of Bathylasma corolliforme, and bryozoan colonies.

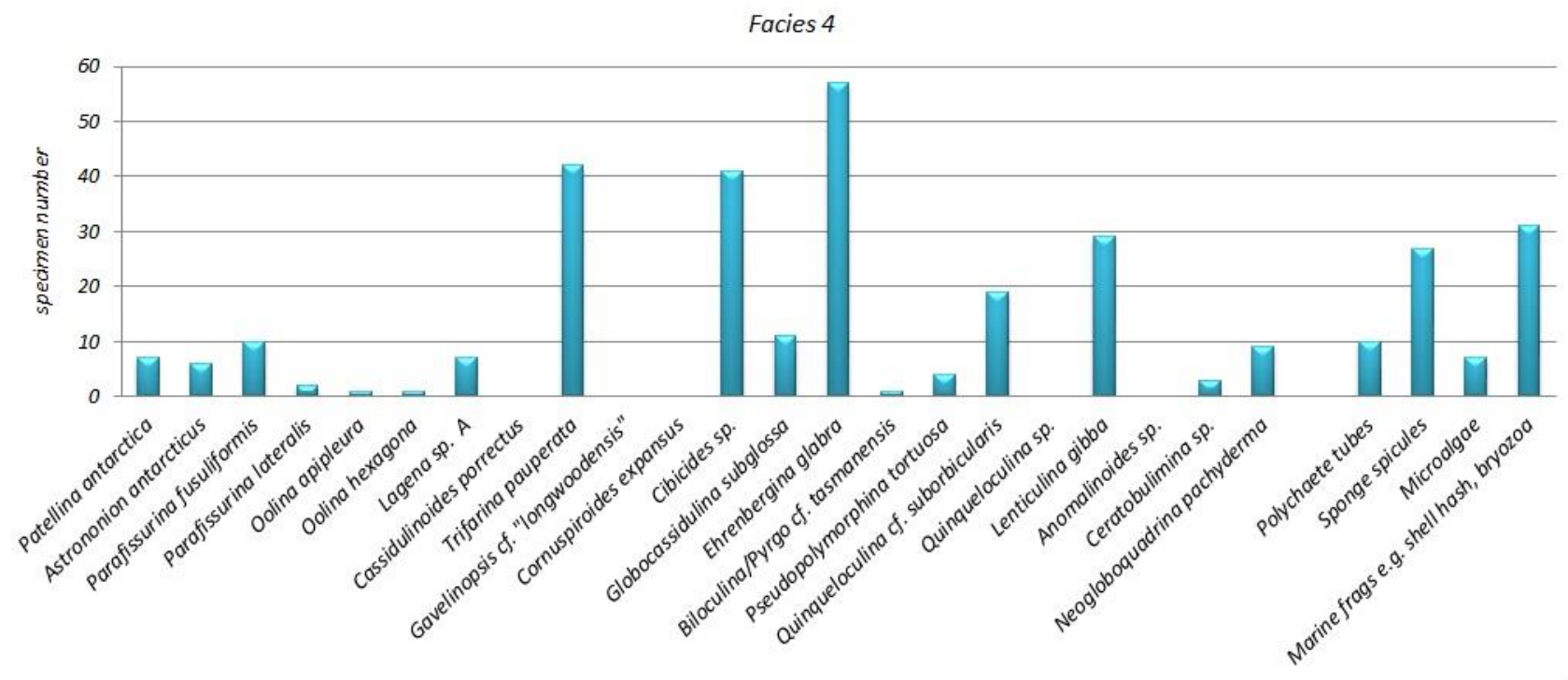

Figure 4.20: Foraminifera species and additional microfossils recovered from Facies 4; DO3A $120 \mathrm{~cm}$. Data available in Appendix B.

\subsubsection{Facies Five, Stratified Diamictite - Fig. 4.21}

Facies Five is characterised by the second lowest number of foraminfera specimens per gram of sample. A total of 344 specimens were picked from 18 grams of sample weight, dominated by Ehrenbergina glabra, Cibicides sp. Trifarina pauperata, Lenticulina gibba, Globocassidulina subglossa, and Quinqueloculina suborbicularis. Oolina hexagona, 
Astrononian antarcticus, Cornuspiroides expansus, Parafissurina fusiliformis, and Parafissurina lateralis, are also present but less abundant. Serpulid polychaete tubes, bryozoan colonies, and Bathylasma corolliforme fragments are also common in Facies Five, but algae material is absent.

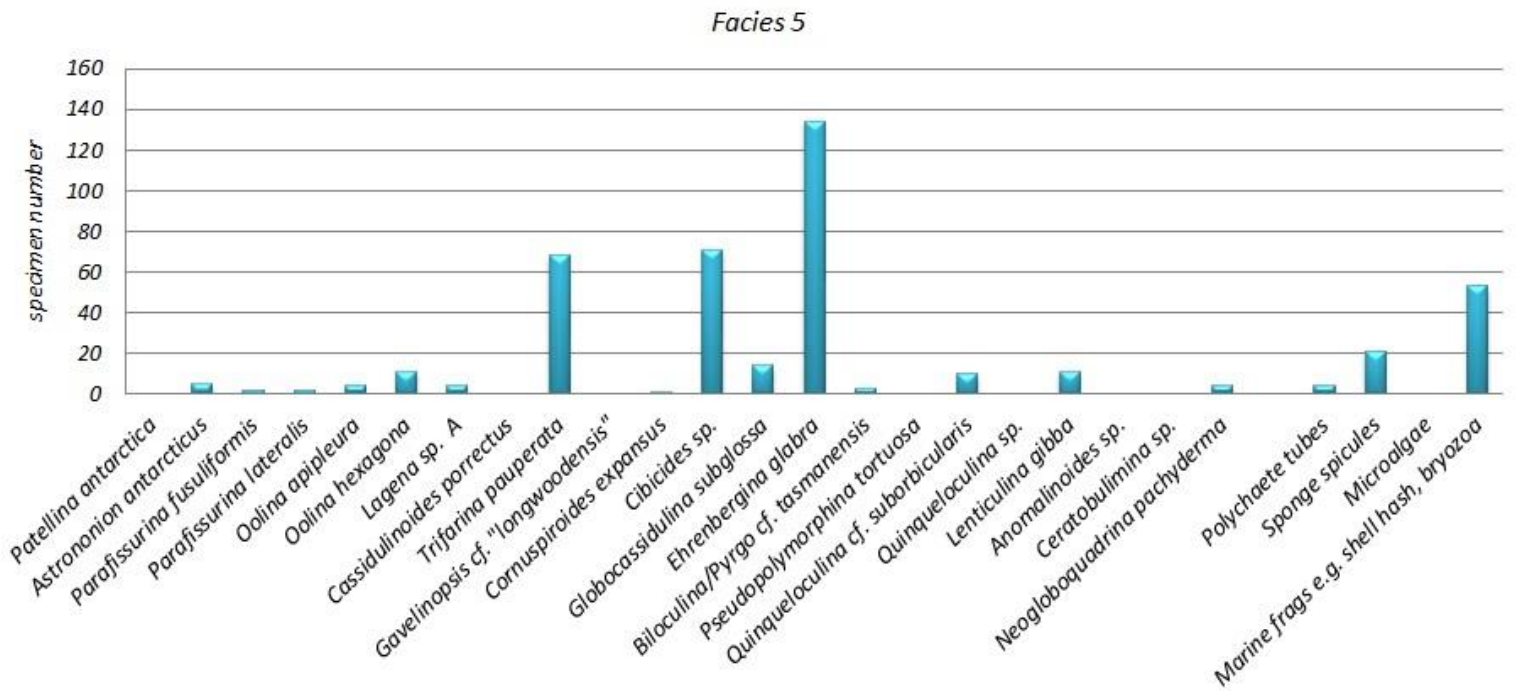

Figure 4.21 Foraminifera species and additional microfossils recovered from Facies 5; DO3A $60 \mathrm{~cm}$. Data available in Appendix B.

\subsubsection{Facies Six, Massive Diamictite - Fig. 4.22}

Facies Six records the lowest number of specimens per sample (7) and contains zero planktic foraminifera. Lithofacies analysis indicates that deposition of Facies 6 occurred either subglacially or in very close proximity to the grounding line. 47 foraminifera in total were recovered from 6.7 grams of sample and once again Ehrenbergina glabra, Cibicides sp. Trifarina pauperata, and Globocassidulina subglossa make up the majority of fauna. Oolina hexagona, Oolina apiopleura, Lenticulina gibba, and Ceratobulimina sp., also feature in Facies 6 , at trace abundance ( $<3$ specimens each). Unlike the previous diamictite facies, unidentified algae material is present in Facies 6, along with sponge spicules, serpulid polychaete tubes, bryozoan colonies, and fragments of Bathylasma corolliforme. 


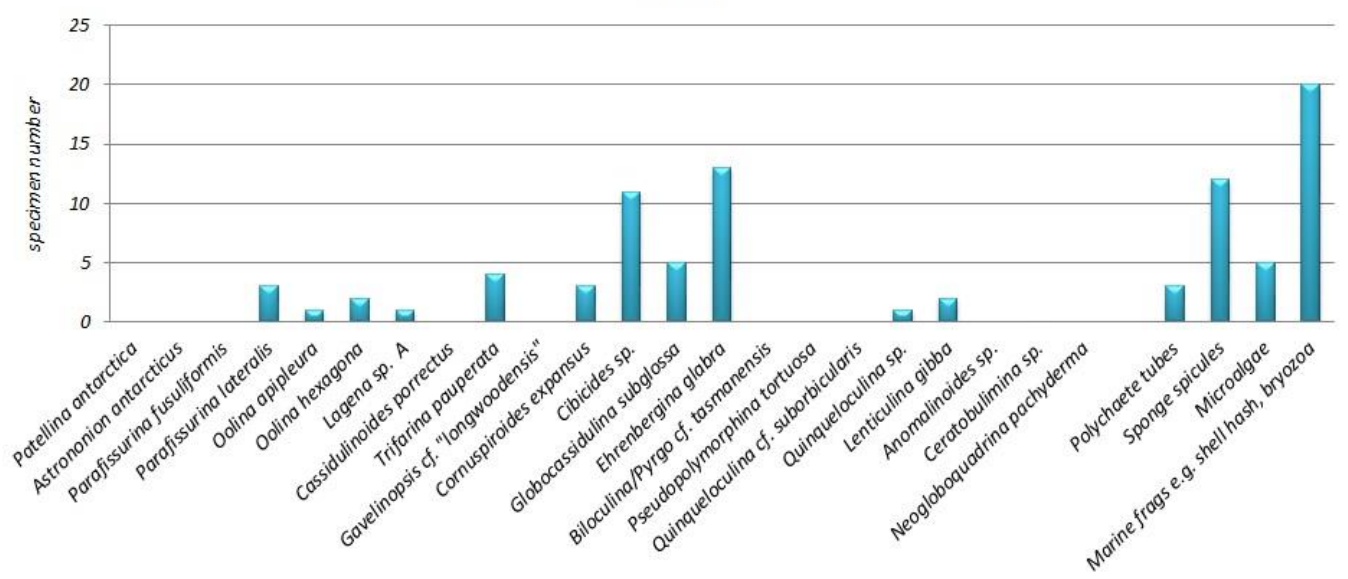

Figure 4.22: Foraminifera species and additional microfossils recovered from Facies 6; DO1A $590 \mathrm{~cm}$. Data available in Appendix B.

Two Brown Peninsula samples were examined for the presence of foraminifera to try and provide a comparison with data obtained from DO1A and DO3A. However, diamictite BO1AB $120 \mathrm{~cm}$ and conglomerate $\mathrm{BO} 1 \mathrm{AB} 180 \mathrm{~cm}$ were both found to be almost completely barren of foraminifera. A total of 0.9 specimens per gram of sample were recovered from BO1AB 120 $\mathrm{cm}$, while BO1AB $180 \mathrm{~cm}$ produced 3.5 specimens per gram. Both samples contain 0\% planktic foraminifera and algae material is present in trace amounts. Despite being low in species abundance and richness, foraminifera identified include Cibicides sp., Ehrenbergina glabra, Globocassidulina subglossa, and one individual Astrononian antarcticus, which is consistent with foraminifera recovered from DO1A and DO3A.

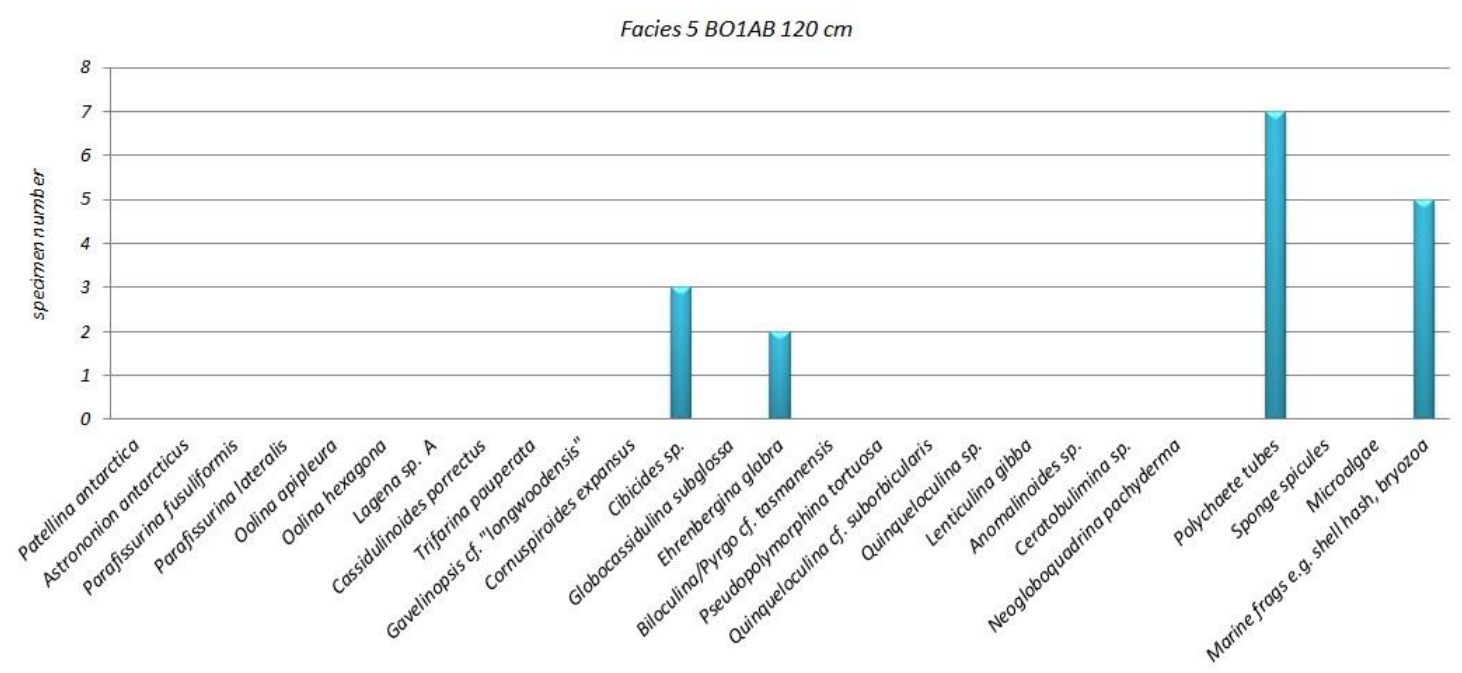

Figures 4.23: Foraminifera species and additional microfossils recovered from BO1AB $120 \mathrm{~cm}$. Data available in Appendix B. 


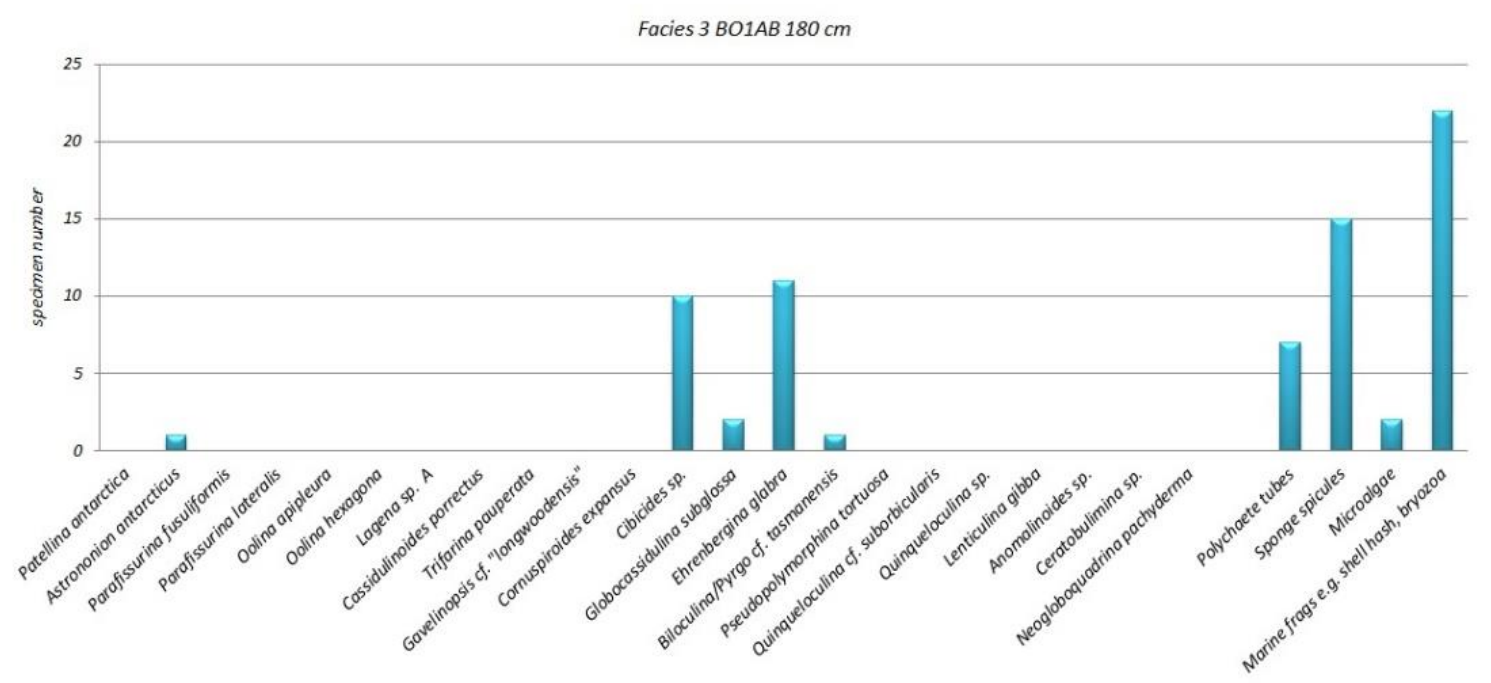

Figure 4.24: Foraminifera species and additional microfossils recovered from BO1AB $180 \mathrm{~cm}$. Data available in Appendix B.

\subsection{Macrofauna}

Macrofaunal fossil emains recovered from $\mathrm{DO} 1 \mathrm{~A} / 3 \mathrm{~A}$ and $\mathrm{BO} 1 \mathrm{AB}$ are low in species richness and exhibit significant variations in abundance between each sample. Identification of Antarctic molluscs was carried out at GNS Science with assistance from Alan Beu, while barnacle fragments were identified by John Buckeridge (Royal Melbourne Institute of Technology). Fragments of the Antarctic cirripede Bathylasma corolliforme (Fig. 4.27) dominate shell material across all samples; this species is an important indicator of paleoenvironmental conditions as it no longer occupies inshore McMurdo Sound. Species identified by Beu consist of a fragment of a Dentalium (genus unidentifiable) (Fig. 4.26), and a single Eumetula delecta (Fig. 4.26), Naticidae prolacuna (Fig. 4.26) and Pareuthria plicatula (Fig. 4.26), all from within sediments of conglomerate Facies 3 and 4. One individual Powellisetia (Fig. 4.26) was found within diamictite sediments of Facies 5, and one specimen of the solitary coral Gardineria antarctica (Fig. 4.26) was also recovered from within diamictite Facies 5 of BO1AB. These species provide no age diagnostic information, but their presence is still included for paleoenvironmental interpretations. 

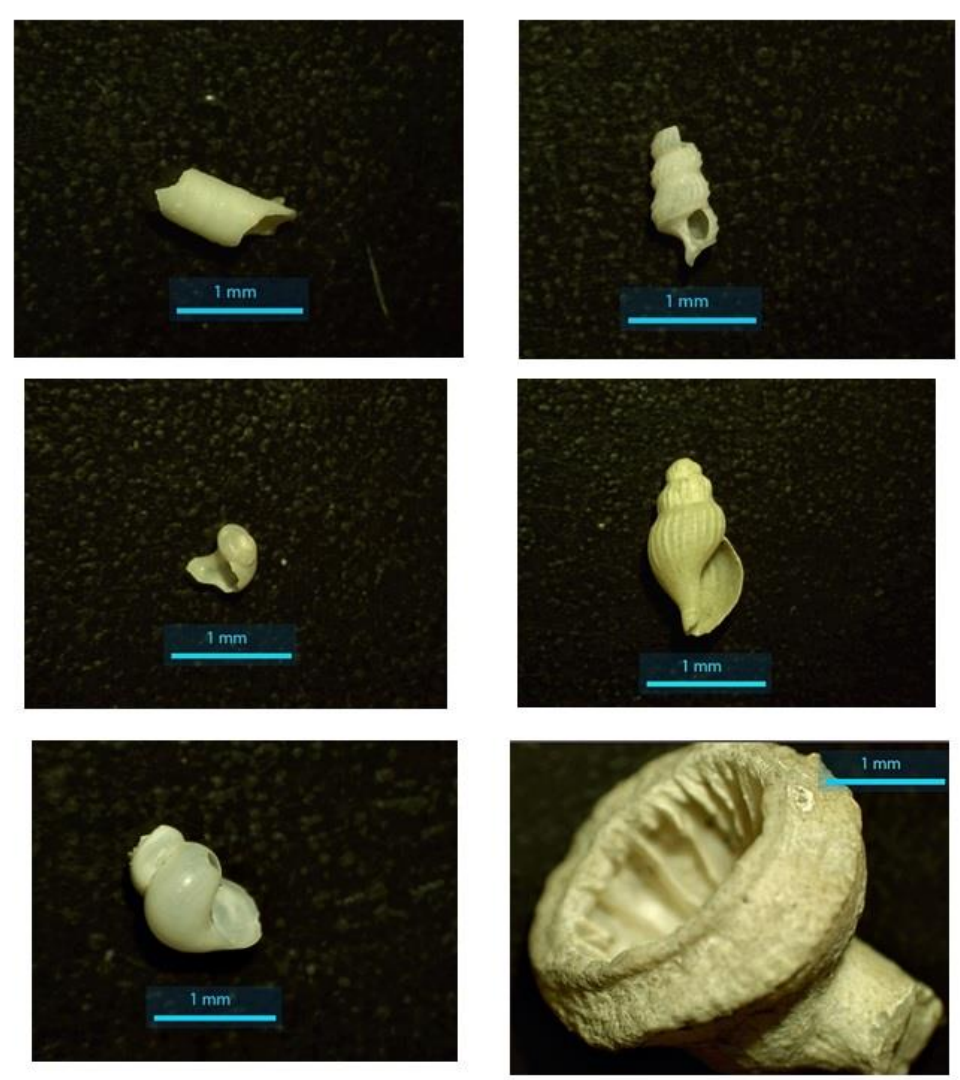

Figure 4.25: L-R: Dentalium (genus unidentifiable); Eumetula delecta; Naticidae prolacuna; Pareuthria plicatula; Powellisetia; solitary coral Gardineria antarctica.

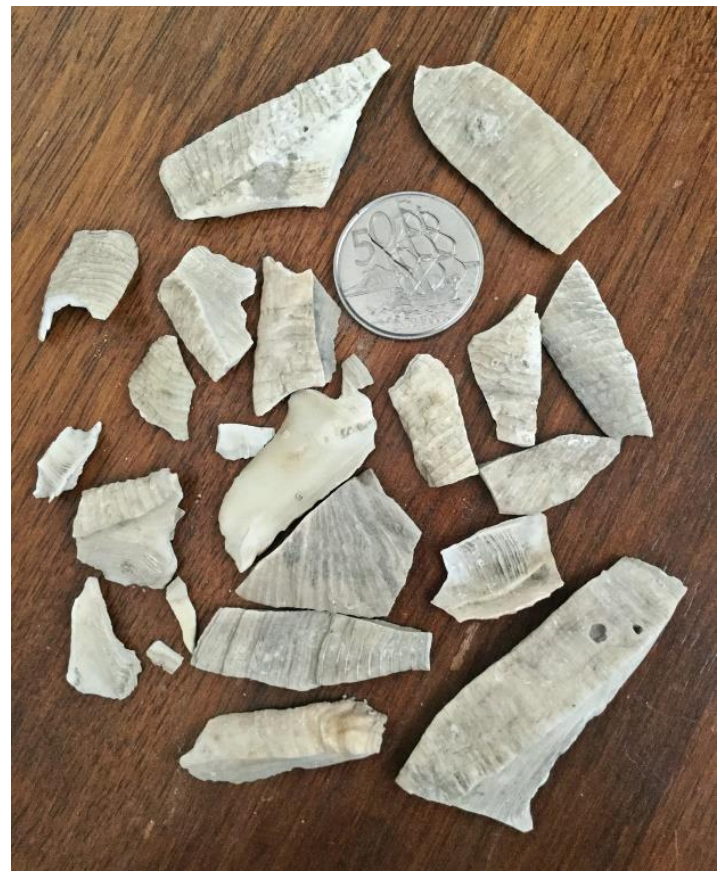

Figure 4.26: Fragments of the Antarctic cirripede Bathylasma corolliforme found in every sample. Coin included for scale.

\section{4 ${ }^{14} \mathrm{C}$ Results}

Measurements of ${ }^{14} \mathrm{C}$ were found to be indistinguishable from ${ }^{14} \mathrm{C}$-free background materials prepared and measured concurrently with each sample. (Fig. 4.28). However, this alone does not rule out the sediments containing the dated material being young, i.e. post-LGM (Rathburn et al., 1997), especially if they are all reworked. Further dating could be carried out on forams at depth, but it is concluded that at this stage that the deposits are older than the range of radiocarbon dating. Additional evidence for this is discussed below.

\begin{tabular}{|c|c|c|c|}
\hline \multirow{2}{*}{ Sample ID } & CRA & $\Delta^{14} C$ & $\delta C^{13}$ \\
\cline { 2 - 4 } & {$[\mathrm{yBP}]$} & {$[\% \circ]$} & {$[\% \circ]$} \\
\hline D01A 20cm & Background & -997.4 & 0.9 \\
\hline BO1B 30cm & Background & -999.6 & 0.5 \\
\hline
\end{tabular}

Figure 4.27: Measurements of ${ }^{14} \mathrm{C}$ found to be indistinguishable from ${ }^{14} \mathrm{C}$-free background materials prepared and measured concurrently with each sample. 


\section{Discussion}

\subsection{Paleoenvironmental interpretation}

Foraminifera identified in this study provide additional information on the depositional environments recorded in $\mathrm{DO} 1 \mathrm{~A} / 3 \mathrm{~A}$ and $\mathrm{BO} 1 \mathrm{AB}$. Paleoenvironmental interpretations outlined in the following discussion are based on the modern distribution of foraminifera around Antarctica, as well as on correlations with the faunal record recovered from previous drilling projects in McMurdo Sound.

In general, foraminifera recovered from Facies 1-6 are comparable to the Shallow Open Water Assemblage that occupies present-day McMurdo Sound (Ward et al., 1987). An irregular calcium carbonate compensation depth (CCD) in the Ross Sea is thought to be the main factor contributing to the distribution of foraminifera, rather than water depth (Kennett, 1968; Anderson, 1975; Osterman and Kellogg, 1979). The CCD in the Ross Sea has been previously associated with primary productivity and the mixing of water masses (Osterman and Kellogg, 1979). Heavy pack ice is thought to elevate dissolved $\mathrm{CO}_{2}$ in the water, raising the $\mathrm{CCD}$ above the seafloor and reducing primary productivity in a more acidic environment (Osterman and Kellogg, 1979). Such conditions on a shelf or upper slope environment would inhibit calcareous taxa and instead favour agglutinated taxa (Osterman and Kellogg, 1979). This situation is not observed in the $\mathrm{DO} 1 \mathrm{~A} / 3 \mathrm{~A}$, nor $\mathrm{BO} 1 \mathrm{AB}$, record.

Alternatively, oxygenated water masses in the Ross Sea may depress the CCD in favour of calcite precipitation and preservation (Osterman and Kellogg, 1979). Today these oxygenated water masses consist of the Ice Shelf Water (ISW), Ross Sea Shelf Water (RSSW), and Fresh Shelf Water (FSW). ISW emanates from the seasonal melting of sea ice during the summer months, whereas RSSW is derived from freezing at the base of the Ross Ice Shelf (Milam and Anderson, 1981). The FSW can also be influenced by an increase in precipitation and fresh water input (Osterma and Kellogg, 1979). The dominance of calcareous taxa in the DO1A/3A and $\mathrm{BO} 1 \mathrm{AB}$ record implies environmental conditions favouring calcite precipitation and preservation. Due to their association with oxygenated water masses, such environmental conditions may have occurred at any one time, or reflects the combined influence of ice shelf, seasonal sea ice, and/or intervals of open water with freshwater input.

Fauna recovered from Facies 1-6 include a number of eurytopic taxa that are more tolerant of environmental changes (Leckie and Webb; 1983; Strong and Webb, 2006). Cassidulinoides 
and Cibicides, also found in the CRP 2-2A and AND-2A record, may represent a dynamic glacial environment that fluctuates episodically from glacially stressed to less glacially stressed (Strong and Webb, 2006; Patterson and Ishman, 2012). A dominance of these taxa may also be an indicator of sedimentation rates varying from high to low in an unstable glacial environment (Leckie and Webb; 1983; Strong and Webb, 2006; Patterson and Ishman, 2012). Comparatively barren intervals in the $\mathrm{DO} 1 \mathrm{~A} / 3 \mathrm{~A}$ and $\mathrm{BO} 1 \mathrm{AB}$ relative to Facies 1 and 2 are also thought to reflect a fluctuating and unstable glacimarine environment during transition events that restrict the precipitation and preservation of calcium carbonate. The dominance of Cibicides is significant as it is an epibenthic taxa, implying high bottom current activity due to its attached mode of life (Murray, 1991; Ishman and Szymcek, 2003). The occurrence of Cibicides within sediment with shell fragments supports the notion of periods of increased turbidity in the water.

Ehrenbergina glabra is another important species in the $\mathrm{DO} 1 \mathrm{~A} / 3 \mathrm{~A}$ and $\mathrm{BO} 1 \mathrm{AB}$ record as it has been previously associated with ice edge conditions (Ishman and Szymcek, 2003). The appearance of Ehrenbergina glabra in Pleistocene sediments, in addition to Globocassidulina subglossa, and Cassidulina porrectus, have been associated with shallow areas of the southwestern Ross Sea and RSSW (Osterman and Kellogg, 1979). Ehrenbergina glabra and Globocassidulina subglossa have known affinities with the Fresh Shelf Water mass, and are considered important components of the eastern Weddell Sea continental shelf benthic foraminiferal assemblage (Anderson, 1975). Previous studies have also attributed Ehrenbergina glabra and Globocassidulina subglossa to a stable environment with a high nutrient availability (Ishman and Reick, 1992). As diatoms are absent in the DO1A/3A and $\mathrm{BO} 1 \mathrm{AB}$ record, the presence of Ehrenbergina glabra most likely indicates proximal glacial conditions. The presence of the planktonic species Neogloboquadrina pachyderma confirms true polar conditions and ice influence (Kennett, 1968; Lipps, 1979; Ishman and Szymcek, 2003; Patterson and Ishman, 2012).

Bathylasma corolliforme is another key indicator of paleoenvironmental conditions as the species is known to have occupied southern McMurdo Sound during the Plio-Pleistocene (Speden, 1962), but today has a circumpolar distribution in water depths ranging upwards from $100 \mathrm{~m}$ to $1500 \mathrm{~m}$ (Dayton et al., 1982). A similar extant genus, Bathylasma hirusutum, has shown to only feed in current velocities in excess of $1 \mathrm{~cm} \mathrm{~s}^{-1}$ and exhibits a biological preference for velocities in the order of $5 \mathrm{~cm} \mathrm{~s}^{-1}$ (Southward and Southward, 1958; Dayton et al., 1982). Current velocities of this strength would require input from much stronger wind- 
driven currents during intervals of no permanent shelf ice (Southward and Southward, 1958; Dayton et al., 1982).

The ecological relationship between Antarctic shelled gastropods and microalgae is poorly constrained due to only a handful of studies investigating the feeding behavior of Antarctic gastropods and their interaction with microalgae (e.g. Linse et al., 2006; Clarke et al., 2007; Amsler et al., 2015). However, gastropods in many other marine communities are known to be important grazers of microalgae (Underwood, 1980). These modern intertidal and benthic fauna are dependent on an influx of pelagic productivity which peaks in the Ross Sea during summer months following the break-up of pack ice (Amsler et al., 2015).

Shelled gastropod species Powellisetia, Pareuthria plicatula, and one Naticidae prolacuna specimen, found within re-worked conglomerate sediments of DO1A are herbivorous species that today range in water depths of 100-400 m, and possess chitinous teeth and musculature better suited for scraping diatoms and filamentous material rather than cutting into surfaces (Amsler et al., 2015). As no diatom species have been recovered from samples within this study, presumably due to periodic disturbances in the water column from turbid meltwater plumes, an association with microalgae is more likely (Amsler et al., 2015). The relative abundance of microalgae remains within Facies 1 and 2 implies primary productivity increased during interglacial intervals when ice coverage was significantly reduced (Amsler et al., 2015). Although no consistent pattern of gastropod composition and algal host preference exists for Antarctic environments, gastropod species identified in this study may have established in concert with microalgae communities, and in turn enhanced the photosynthesis capabilities of their host algae by consuming emerging endophytic filaments and other foul epiphytic microalgae (Amsler et al., 2015).

Fauna recovered from the $\mathrm{DO} 1 \mathrm{~A} / 3 \mathrm{~A}$ and $\mathrm{BO} 1 \mathrm{AB}$ record indicate deposition in a dynamic glacial environment. An inner- to mid-shelf setting with water depths $\sim 400 \mathrm{~m}$ is suggested based on appearance of Ehrenbergina glabra, Globocassidulina subglossa, and Cassidulina porrectus, as well as on the occurrence of gastropods Powellisetia and Pareuthria plicatula. This finding is consistent with results from lithofacies analysis, and is supported by the PlioPleistocene foraminifera record of AND-2A (Patterson and Ishman, 2012). The Ehrenbergina glabra Assemblage zone occurs in AND-2A within the diamictite Facies 1 and represents a glacially dominated depositional environment that is punctuated by intervals of ice-free marine to iceberg-influenced conditions (Passchier et al., 2010). Within this section of AND-2A is a 
diatom-bearing diamict unit which contains the most abundant foraminifera record recovered. This unit is dominated by foraminifera that are associated with ice edge biofacies in the Peninsula region, including Neogloboquadrina pachyderma, Ehrenbergina glabra, and Globocassidulina subglossa.

Similar occurrences of foraminfera and paleoenvironmental conditions for the Plio-Pleistocene have been recorded in previous drilling projects in McMurdo Sound. These earlier investigations serve as a base line for interpreting the paleoenvironmental record contained in DO1A/3A and BO1AB. Ishman and Webb (1988), for example, discuss the abundance of Ehrenbergina glabra in association with sedimentological evidence that implies glacial activity and the influence of grounded ice-induced bottom water alteration events in Taylor Fjord. The Plio-Pleistocene record contained in AND-1B also indicates episodes of grounded ice, sub-ice shelf, and ice-shelf conditions in McMurdo Sound (Naish et al., 2009).

\subsection{Depositional model for the Mt Discovery glacimarine deposits}

The following discussion provides an interpretation of the changing paleoenvironmental conditions represented in glacimarine sedimentary sections DO1A/3A within a depositional model that accounts for several fluctuations of a marine ice sheet grounding zone within southern McMurdo Sound. The model is based on the environmental interpretation of sedimentary facies and their constituent fossil fauna outlined in the previous discussion.

On the basis of the repetitive occurrence of the 6 facies up section DO1A and DO3A, a characteristic sequence stratigraphic motif, representing a typical cycle of advance-retreat-readvance of the grounding line across the continental shelf is outlined in Fig. 5.1. The sequence motif is idealized, and Fig. 5.2 shows the interpreted environments represented in sections DO1A and DO3A along a schematic shore-normal profile from ice proximal to ice distal depositional environments. Section DO3A is considered to be deposited in a relatively more ice-proximal environment due to the occurrence of massive diamictite units (Facies 6) that overlie a sharp erosion surface characterized by physical intermixing of super and subjacent lithologies, soft sediment deformation features, and clastic intrusions, whereas section DO1A contains only a single massive diamictite (Facies 6) at its base and the basal contact was not observed. In general, coarse grained facies in DO1 A consist of stratified conglomerates (Facies 3 and 4) and diamictites (Facies 5) and are associated with sub-glacial fluvial discharge within a submarine delta, or sediment gravity flows in a grounding line proximal wedge or fan system (Lønne, 1995; Fielding et al., 2000; Powell et al., 2000; Krissek et al., 2007; McKay et al., 
2009), but do not show evidence of ice overriding. Massive diamictites (Facies 6) in DO3A are considered to be of subglacial origin and directly overlie a glacial surface of erosion as has been described for glacimarine sequences in the Oligocene-Miocene CRP-2A and Pliocene AND-1B drill cores from McMurdo Sound (Domack et al., 1999; Powell et al., 2000; Fielding et al., 2000; Krissek et al., 2007; Dunbar et al., 2008; McKay et al., 2009). Fine grained facies in DO1A are typically muddier (Figs. 4.10;4.11) and higher in open water planktic forams (Facies 1) representing a more offshore distal shelf environment during interglacials. In contrast section DO3A fine-grained facies are dominated by laminated muds and sands (Facies 2) indicative of rapid sedimentation from sediment-laden plumes. These tidal rythmites known as cyclopels (mud-dominated) and cyclopsams (sand-dominated) are characteristic of grounding-line proximal environments in sub-polar and temperate tide-water glaciers (Mackiewicz et al., 1984; Powell and Molnia, 1989; Ó Cofaigh and Dowdeswell, 2001; Powell and Domack, 2002).

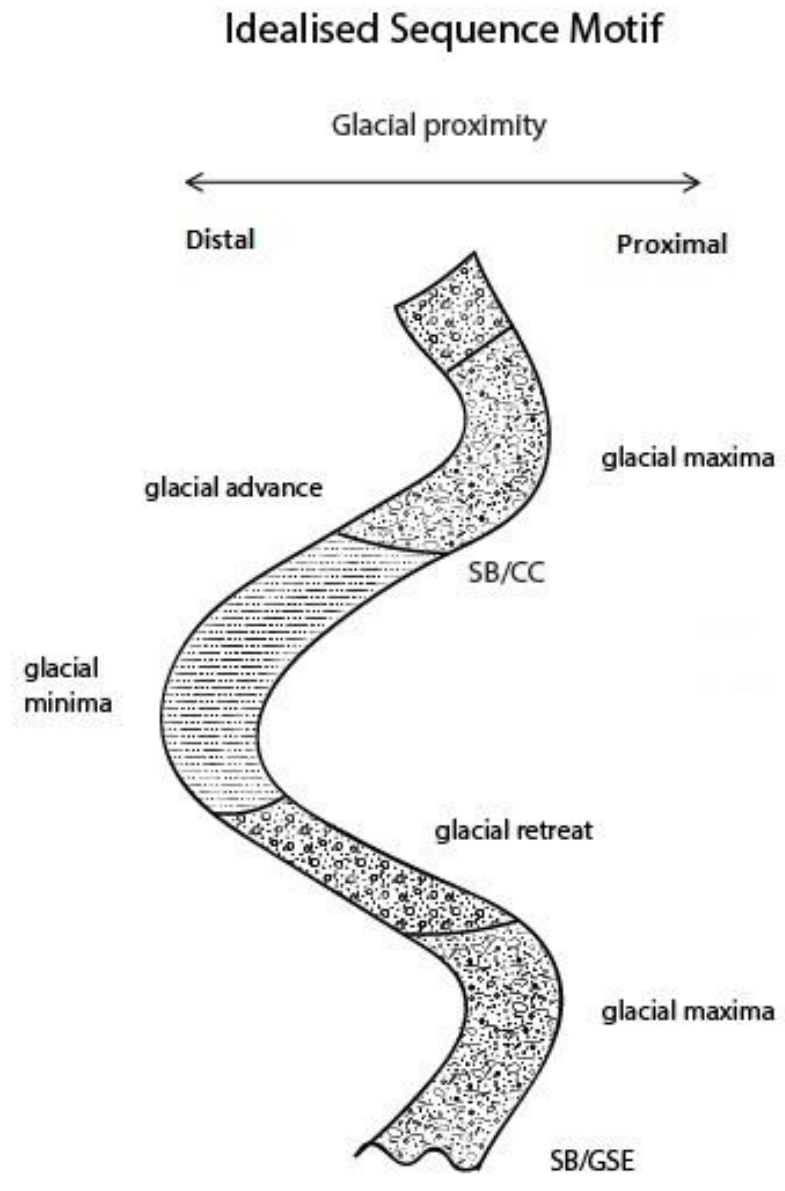

Figure 5.1: Idealised sequence motif represented by the Mt Discovery glacimarine deposits. 
An idealised sequence motif represented in the Mt Discovery glacimarine deposits comprises the following elements in ascending stratigraphic order:

1. A sequence boundary (SB)/basal glacial surface of erosion (GSE) or its correlative conformity (CC) seaward of the grounding line (Fig. 5.1). The SB/GSE is sharp, with erosional irregular $\mathrm{cm}$-scale relief and marks a facies dislocation (e.g. diamictite facies 6 directly overlies sandy mudstone facies 1 ) (Figs. 4.1; 4.2). The correlative conformity usually displays an abrupt transition from a more distal facies to a more proximal facies (Eyles and Eyles, 1992; Dowdeswell et al., 1998; Fielding et al., 2000; Powell et al., 2000; Ó Cofaigh and Dowdeswell, 2001; Krissek et al, 2007; McKay et al, 2009).

2. A massive (Facies 6) or stratified (Facies 5) diamictite. In the case of massive diamictites they often include rip up extraclasts of the underlying lithology, intraclasts, rotated clast with matrix halos, and soft sediment deformation (Hart and Roberts, 1994; Domack et al., 1999; Powell et al., 2000; Fielding et al., 2000; Ó Cofaigh and Dowdeswell, 2001; Krissek et al., 2007; McKay et al., 2009). Sharp basal contacts, observed clast alignment, and a lack of bioturbation, in Facies 6 deposition was occurring either subglacially, or in very close proximity to, the grounding line (Fig. 5.2). Stratified diamictites overly correlative conformities and stratification is typically defined by clast alignment, and weak decimeter scale parallel bedding in the matrix, and in some cases distinct finning upwards graded beds both defined by clast concentration and matrix (Figs. 4.1; 4.2; 4.11; 4.12; 4.13; 4.14) (Hart and Roberts, 1994; Domack et al., 1999; Powell et al., 2000; Fielding et al., 2000; Ó Cofaigh and Dowdeswell, 2001; Krissek et al., 2007; McKay et al., 2009).

3. In some cases the diamictite passes gradationally-upwards or is sharply overlain by a conglomerate (Figs. $4.1 ; 4.2 ; 4.11 ; 4.12 ; 4.13$ ) (Facies 3 or 4 ) representing appearance of fluvio-deltaic deposition or debris flows in the grounding zone wedge as the glacier grounding line begins to retreat (Fig. 5.2) (Lønne, 1995; Fielding et al., 2000; Powell et al., 2000; Krissek et al., 2007; McKay et al., 2009).

4. Conglomerates are in turn overlain often sharply by hemipelagic laminated (Facies 2) or massive mudstone (Facies 1) and represent the most ice distal and marine part of the sequence at the interglacial minima (Figs. 4.1; 4.2; 5.2) (Eyles and Eyles, 1992; Dowdeswell et al., 1998; Fielding et al., 2000; Ó Cofaigh and Dowdeswell, 2001; McKay et al, 2009). Foraminiferal evidence from Facies 1 and 2 indicate deposition in 
a dynamic glacial environment with water depths $\sim 400 \mathrm{~m}$ based on appearance of Ehrenbergina glabra, Globocassidulina subglossa, and Cassidulina porrectus.

5. A proglacial facies successions is sometimes preserved below the GSE or correlative conformity bounding the top of the sequence and usually consists of a transition from muddy facies into grounding zone proximal conglomerates during re-advance of the grounding line (Fig. 5.2) (Eyles and Eyles, 1992; Dowdeswell et al., 1998; Fielding et al., 2000; Ó Cofaigh and Dowdeswell, 2001; McKay et al, 2009).
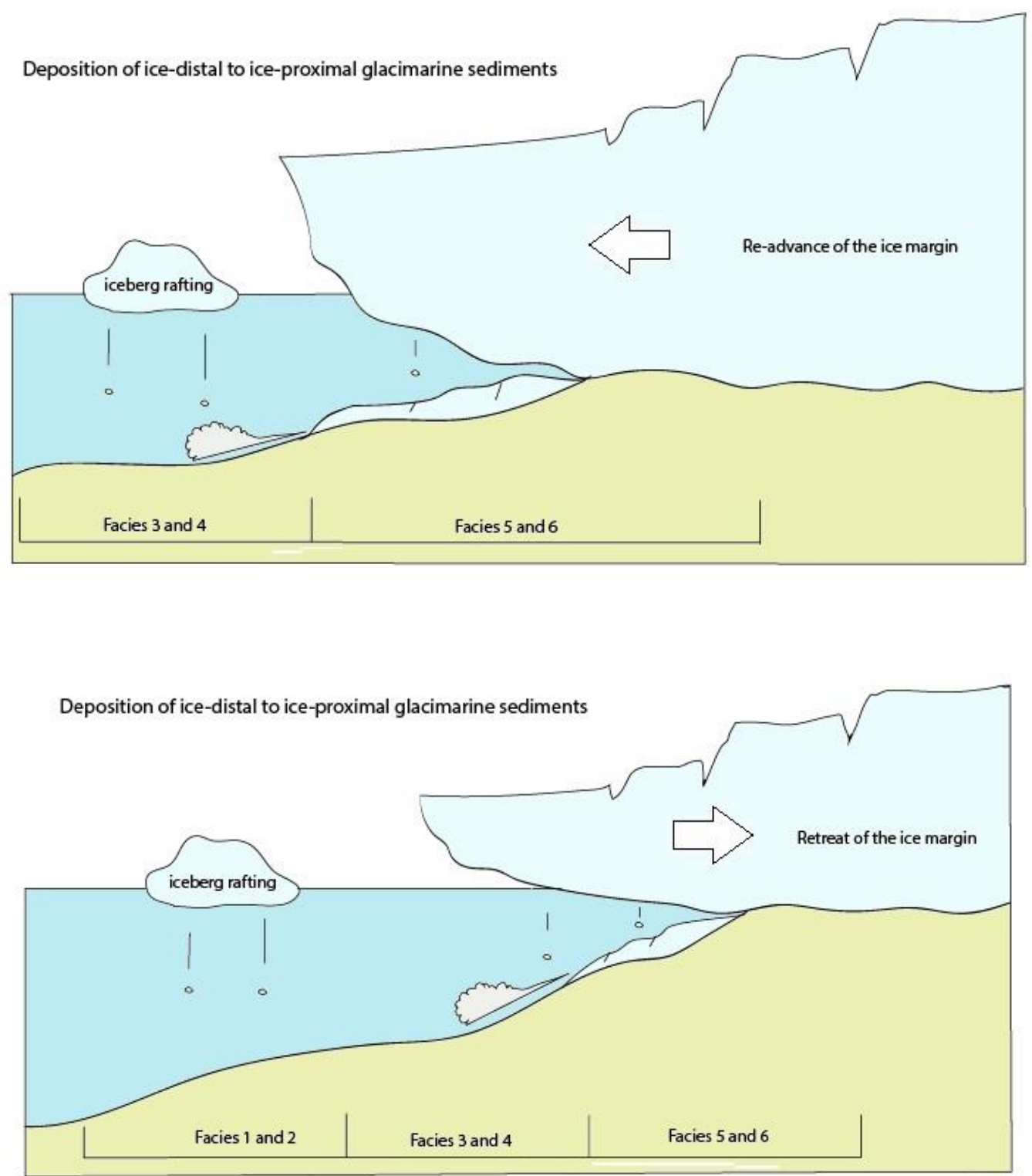

Figure 5.2: Inferred locations of Facies 1-6 along a schematic shore-normal profile from ice proximal to ice distal depositional environments. Figure not drawn to scale so as to exaggerate the inferred depositional setting of each facies. 
Interpreting a glacial history from the sequence preserved in Brown Peninsula sites BO1AB is not as straightforward as the record contained in DO1A/DO3A. Establishing a correlation between $\mathrm{BO} 1 \mathrm{AB}$ and the two Mount Discovery glacimarine sequences is hampered by a relative lack of marine fauna in Brown Peninsula samples and a complete absence of any isochronous horizons, i.e. dateable tephra layers. The lack of direct age control for either sequence has restricted attempts to place $\mathrm{BO} 1 \mathrm{AB}$ within the context of environmental change that is inferred to be taking place at Mount Discovery. However, a few specimens of Ehrenbergina glabra, Cibicides sp., Globocassidulina subglossa, and one individual Astrononian antarcticus, as well as abundant fragments of Bathylasma corolliforme, are consistent with assemblages from DO1A/3A. These taxa suggest deposition at Brown Peninsula was taking place in a polar glacimarine regime similar to that of Mount Discovery. Unlike the sequence observed at Mount Discovery, no episodes of widespread open water deposition are evident in the BO1AB glacimarine sequences (Eyles and Eyles, 1992; Dowdeswell et al., 1998; Fielding et al., 2000; Ó Cofaigh and Dowdeswell, 2001; McKay et al, 2009). Instead, stratified diamictite and matrix-supported conglomerate sediments (Figs. 4.3 ; 4.12) reflect deposition across a range of grounding-line proximal environments comparable to those of DO1A/3A Facies 4-5 (Eyles and Eyles, 1992; Hart and Roberts, 1994; Dowdeswell et al., 1998; Domack et al., 1999; Powell et al., 2000; Fielding et al., 2000; Ó Cofaigh and Dowdeswell, 2001; Krissek et al., 2007; McKay et al., 2009).

Although no pieces of extinct Chlamys (Zygochlamys) anderssoni shell were found in-situ, erratics bearing remains of Scallop Hill Formation were found nearby the Brown Peninsula sequence. This unfortunately does not provide any confidence that $\mathrm{BO} 1 \mathrm{AB}$ is comparable to the Scallop Hill Formation, nor is of equivalent age.

\subsection{Timing of Deposition and Paleoenvironmental Significance}

The paleoenvironmental significance of glacimarine sequences $\mathrm{DO} 1 \mathrm{~A} / 3 \mathrm{~A}$ and $\mathrm{BO} 1 \mathrm{AB}$ is largely dependent on the time interval during which they were deposited. As radiocarbon results are inconclusive, indicating an age older than Last Glacial Maximum (> 18 ka) and no age-diagnostic marine fauna have been identified, indirect constraints on the time of deposition have been inferred from uplift of the sites through a combination of glacio-isostatic and tectonic uplift. Although volcanic loading is known to produce lithospheric flexure in the region, the emplacement of Ross Island on the crust between 5 and $1 \mathrm{Ma}$, cannot account for the uplift of the deposits on the flanks of Mount Discovery and Brown Peninsula, as these sites are not 
located on the peripheral bulge of the flexure (Aitkin et al., 2012). Instead, this study considers the effect of changes in ice volume and extent on the underlying crust, and interprets the elevation history of the sites in terms of the viscoelastic response of the crust due to isostatic rebound as a response of ice loading and unloading, and uplift associated with glacial incision and erosion in the adjacent Transantarctic Mountains (e.g. Stern et al., 2005).

This latter process of isostatic uplift has been used in previous investigations to account for why the Transantarctic Mountains record the highest uplift and vertical elevation of any riftflank in the world, and provides a mechanism to explain evidence of Pliocene uplift along the Transantarctic Mountain front in southern Victoria Land (Levy et al., 2012). Neogene (25-3 Ma) fossiliferous glacimarine deposits along the Victoria Land coast and within the Dry Valleys that were deposited at or below present day sea-level now sit hundreds of meters above sea-level (e.g. Webb and Wrenn, 1982; Ishman and Reick, 1992). Water depths in excess of $300 \mathrm{~m}$ during the early Pliocene are reflected by both foraminiferal assemblages and lithofacies characteristic of deposition within a distal glacimarine fjordal grounding zone environment, while late Pliocene sequences indicate shallower water depths less than $100 \mathrm{~m}$ and an increasing proximity to grounded ice. A combination of falling eustatic sea-level, tectonic uplift, and rapid sedimentation and basin-fill following the early to late Pliocene are most likely responsible for the decrease in relative base-level.

However, to explain the present day elevation of these sites an uplift rate of 100 to $200 \mathrm{~m}$ per Ma is required, and Levy et al. (2012) appealed to the isostatic response of glacial valley downcutting and denudation of the Transantarctic Mountains proposed by Stern et al (2005). The wavelength of the isostatic rebound modelled by Stern et al. (2005) could account for the uplift of the Mt Discovery and Brown Peninsula deposits up to $150 \mathrm{~m}$ above present day sea-level, that is assuming that their rigid plate model is not decoupled by rift bounding faults along the Terror Rift and front of the Transantarctic Mountains. Assuming half the long-term average rate of uplift of 100 to $200 \mathrm{~m} \mathrm{Ma}^{-1}$ of the Transantarctic mountains applies to nearby Mount Discovery, then it is possible that this mechanism explains, at least some of the present day elevation of the sites and that they were last at sea-level during the Pliocene ( 3 Ma) (Fig. 5.3). 


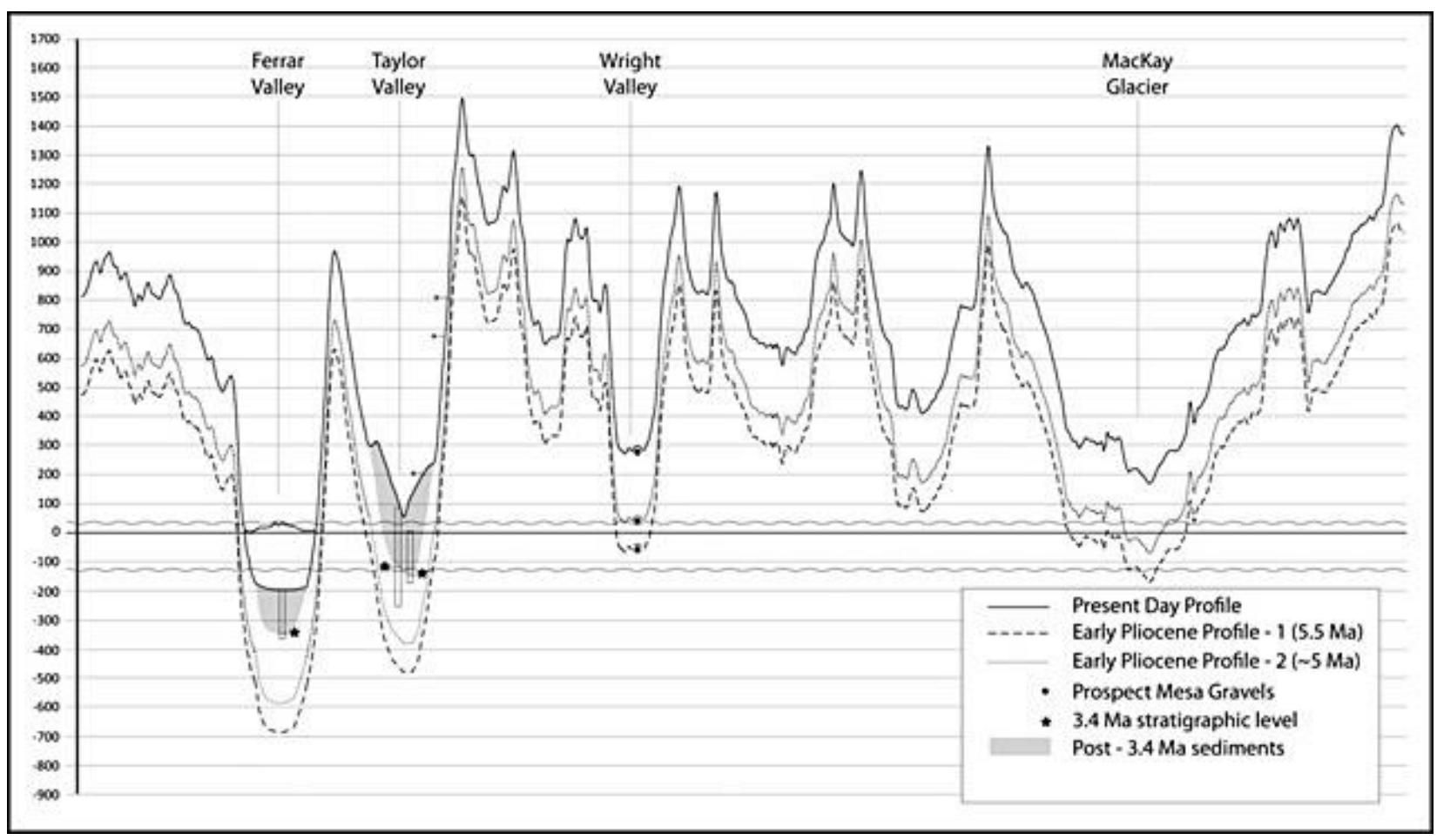

Figure 5.3: Modelled changes in relative sea level along the coast of Southern Victoria Land throughout late Neogene taken from Levy et al. (2012). Figure depicts a north-south cross section along the coastal section of the Transantarctic Mountains in the Dry Valleys region of Southern Victoria Land. Solid black line represents modern topography. Long dashed line represents the adjusted topography for the Early Pliocene. This profile creates a water depth of $\sim 50 \mathrm{~m}$ in the central Wright Valley and accommodates environmental data indicated by the Prospect Mesa Gravels (black circle). This profile also creates water depths (> $300 \mathrm{~m}$ ) in Taylor Valley which fits with foraminiferal-based depth data from DVDP-10 and -11. Short dashed line represents the paleotopography following uplift above sea-level of the Prospect Mesa Gravels in the Early Pliocene. Additional uplift is required to create the Late Pliocene paleotopography that places the 3.4 Ma stratigraphic horizon in the DVDP cores (black star) at $<100 \mathrm{~m}$ water depth. Grey area in the Ferrar and Taylor valleys represents late Pliocene to Recent shallow marine and non-marine sediment fill. Inferred range in Pliocene to Pleistocene eustatic sea level is indicated by wavy lines (Levy et al., 2012).

An alternative explanation involves the role of loading and unloading of the sites during episodes of glacial advance. Fig. 6.4 demonstrates bed elevation of the Mt Discovery sites with respect to present day sea-level during the LGM to as a consequence of glacio-isostatic depression and subsequent unloading of the crust as modelled by Golledge et al. (2015). Comparison with present day sea-level shows the sites were above sea-level during the LGM, and at present day elevation after unloading. In contrast, if the same modelling is undertaken the Marine Isotope Stage M2 glaciation and subsequent deglaciation to the M1 interglacial between 3.310-3.260 Ma, then the sites are depressed below present day sea-level. In Fig. 5.4, the eustatic sea-level curve for this deglacial phase is based on calibrations of the Lisiecki and Raymo (2005) benthic $\delta^{18} \mathrm{O}$ stack by Miller et al. (2012). It is only possible to submerge the 
sites below sea-level with glacio-isostatic loading during ice sheet advance prior to the development of large ice-sheets on the Northern Hemisphere. Fig 5.4 shows that for a global sea-level fall greater than $\sim 50 \mathrm{~m}$ the sites are not submerged. Such sea-level falls began about $\sim 2.7 \mathrm{Ma}$. The effect of the $\sim 80 \mathrm{~m}$ fall during MIS 100 to MIS 99 is shown in Fig. 5.4 and the sites are not depressed below sea-level. There is no possibility of the sites being below present day sea-level for any glacials during the last 2.7 Ma. Moreover, the additional influence of isostatic rebound of the Transantarctic Mountains, described above would further ensure a more recent age for the Mt Discovery of the glacimarine deposits is unlikely. The influence of instantaneous near-field sea-level changes due to gravitational adjustments (e.g. Raymo et al., 2011) have been estimated based on published studies for the Pliocene (Lisiecki and Raymo, 2005; Miller et al., 2012) for the M2-M1 glacial-deglacial (Fig. 5.4). Ice advance during the M2 glaciation would have caused a near-field sea-level rise of as much as $25 \mathrm{~m}$ if the global average sea-level fall was $\sim 10 \mathrm{~m}$, further increasing water depth of the sites. Conversely as the ice sheet retreated local relative sea-level would have fallen both due to gravitational influences and isostatic uplift of Mt Discovery uplifting the sites above sea-level. 


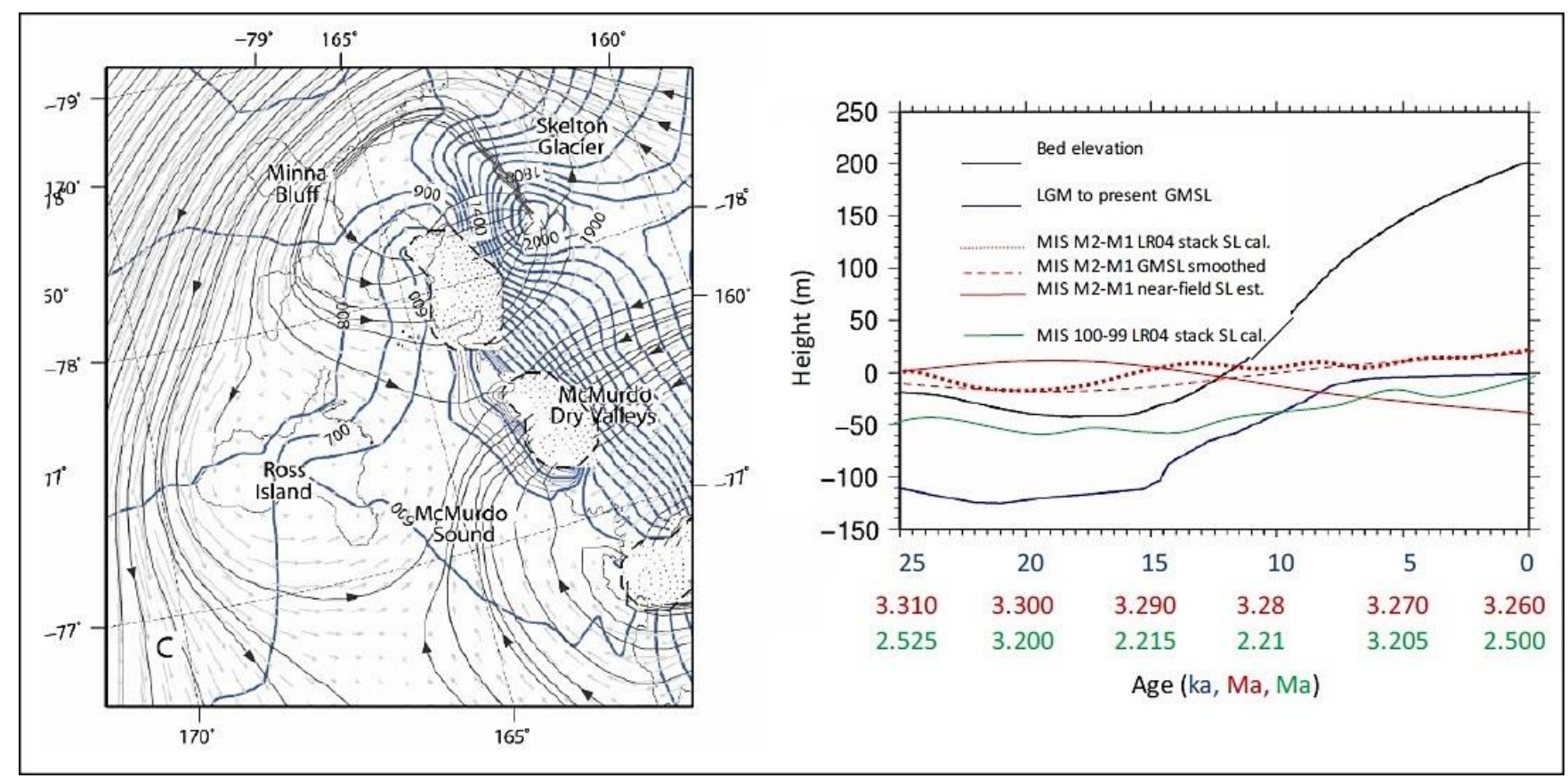

Figure 5.4: Bed elevation of the Mt Discovery sites with respect to both present day sea-level during the LGM, and Marine Isotope Stage M2 glaciation and subsequent deglaciation to the M1 interglacial between 3.310-3.260 Ma. Results indicate the last possible occurrence of deposition below sea level occurred prior to significant northern hemisphere glaciation, is only possible to submerge the sites below sea-level with glacio-isostatic loading during ice sheet advance prior to the development of large ice-sheets on the Northern Hemisphere. Marine isotope stages (MIS) M2-M1 and MIS-100-99 sea-level curves in this model are based on calibrated benthic oxygen isotope stacks from Miller et al., (2012), and a qualitative adjustment has been applied to the smoothed Global Mean Sea Level curve M2M1 to account for $250 \%$ near field sea-level change based on Raymo et al. (2011). The model also assumes that M2, MIS 100, and LGM, either had the same ice loading at Mount Discovery and/or no more than LGM. Taking into account the contribution of Northern Hemisphere ice and an associated fall in global sea-level to below $50 \mathrm{~m}$, even with glacio-isostatic loading and the gravitational influence this ice mass has on local relative sea level, it is still not possible to have marine conditions at DO1A during the LGM. Deposition of DO1A must have occurred between prior to $\sim 2.7 \mathrm{Ma}$, and most likely during the warm interglacials of the middle Pliocene, or potentially earlier.

In absence of any direct age control and on the basis of this indirect evidence it is argued that the Mt Discovery glacimarine successions represent several grounding line fluctuations of a dynamic ice margin in McMurdo Sound during glacial-interglacial cycles of the warmer than present Pliocene sometime between 5 and 2.7 Ma. These results are consistent with foraminiferal evidence that closely resembles faunal assemblages contained in Pliocene sediments of the AND-2A drillcore (Patterson and Ishman, 2012). 


\section{6. $\underline{\text { Conclusions }}$}

\subsection{Summary of results}

The aim of this study was to describe and interpret the occurrence of a succession of fossiliferous glacimarine sediments exposed on the northern flank of Mt Discovery and add to the undertsanding of late Neogene climate and ice sheet variability in McMurdo Sound. More than a century has passed since fossiliferous deposits containing marine invertebrate remains were first discovered in Antarctica. However, outcrops of fossil-bearing sedimentary sequences are sporadic and temporally inconsistent across McMurdo Sound, as well as highly susceptible to erosion and remobilisation with much of Antarctica's geology hidden away or removed beneath extensive volumes of ice. Due to the scattered nature of these relict glacial landforms, understanding Antarctica's ice sheet history and the response of ice to past warmth in Southern McMurdo Sound has been reliant on the recovery sediment cores. The previous $\sim 30$ years' worth of integrated seismic and borehole data has produced the best-understood sedimentary record on the Antarctic margin, serving as a base line for paleoenvironmental interpretations concerning the sedimentological and faunal evidence recovered from glacimarine sequences DO1A, DO3A, and BO1AB.

Six glacimarine lithofacies have been described and interpreted throughout DO1A/3A and $\mathrm{BO} 1 \mathrm{AB}$ sections based on investigations into past and modern depositional processes in highlatitude glacial environments (e.g. Fielding et al., 2000; Ó Cofaigh and Dowdeswell, 2001; Krissek et al., 2007; McKay et al., 2009). Detailed sedimentological descriptions and grainsize analysis, integrated with foraminiferal and macrofaunal evidence, has been used to establish depositional processes and environments, producing an idealised sequence motif and simplified depositional model for the glacial history in southern McMurdo Sound. It is thought that glacimarine successions DO1A and DO3A represent several grounding line fluctuations of a dynamic ice margin in McMurdo Sound during glacial-interglacial cycles of the warmer than present Pliocene sometime between 5 and 2.7 Ma. Lithofacies results are consistent with faunal evidence that indicates deposition in a dynamic glacial environment. An inner- to midshelf setting with water depths $\sim 400 \mathrm{~m}$ is suggested based on appearance of Ehrenbergina glabra, Globocassidulina subglossa, and Cassidulina porrectus, as well as on the occurrence of gastropods Powellisetia and Pareuthria plicatula (Anderson, 1975; Osterman and Kellogg, 1979; Ishman and Reick, 1992. The presence of the planktonic species Neogloboquadrina pachyderma confirms polar conditions and ice influence (Kennett, 1968; Lipps, 1979; Ishman 
and Szymcek, 2003; Patterson and Ishman, 2012). This finding is supported by foraminifera assemblages from Pliocene sediments of the AND-2A core that closely resemble the results of this study (Patterson and Ishman, 2012). The occurrence of Bathylasma corolliforme is another important paleoenvironmental indicator in this study. Although foraminifera recovered are comparable to the Shallow Open Water Assemblage that occupies present-day McMurdo Sound, Bathylasma corolliforme is known to have occupied southern McMurdo Sound during the Plio-Pleistocene (Speden, 1962), but today has a circumpolar distribution in water depths ranging upwards from $100 \mathrm{~m}$ to $1500 \mathrm{~m}$ (Dayton et al., 1982). A similar extant genus, Bathylasma hirusutum, has shown to only feed in current velocities in excess of $1 \mathrm{~cm} \mathrm{~s}^{-1}$ and exhibits a biological preference for velocities in the order of $5 \mathrm{~cm} \mathrm{~s}^{-1}$ (Southward and Southward, 1958; Dayton et al., 1982). Current velocities of this strength require input from much stronger wind-driven currents during intervals of no permanent shelf ice (Southward and Southward, 1958; Dayton et al., 1982).

The evidence presented in this study provides an opportunity to examine paleoenvironmental change in southern McMurdo Sound during an important time in Earth's climate history. Taxa that today have circumpolar distributions and affinities for open water, high primary productivity, and stronger bottom currents, indicate that southern McMurdo Sound has been relatively free of sea-ice and ice shelf coverage in the past, and is therefore capable of losing its permanent shelf ice in the future. Despite being unable to establish a robust chronostratigraphic framework for the deposits, lithofacies point to deposition in an environment that is at times distal from a glacial grounding zone, and dominated by marine fauna characteristic of ice-free conditions. Conclusions drawn from this study provide direct evidence of environmental variability in the high southern latitude geologic record, and enable inferences to be made about the response of ice in McMurdo Sound to warmer-than-present conditions. Given that elevated atmospheric $\mathrm{CO}_{2}$ levels of $\sim 450 \mathrm{ppm}$ during mid-Pliocene peak warmth are comparable to predictions of Earth's climate in the coming decades (IPCC, 2013), this period in Earth's history is considered the best example of how the Earth system will respond to the current warming trajectory (Naish and Zwartz, 2012). A concurrent rise in eustatic sea-level of $+25 \mathrm{~m}$ under a global climate that is up to $4^{\circ} \mathrm{C}$ warmer has a number of serious implications for coastal communities, human society in general, and natural ecosystems (Raymo et al., 2006; Pollard and DeConto, 2009; Pagani et al., 2010; Miller et al., 2012; IPCC, 2013; DeConto and Pollard, 2016). Results from this study are consistent with previous investigations that indicate a dynamic, marine-terminating ice sheet margin in Southern 
McMurdo Sound during the Pliocene, with periods of open ice shelf free conditions potentially associated with more regional collapse and retreat events of a marine-based ice sheet in the Ross Sea embayment (Naish et al., 2009; Pollard and DeConto, 2009; DeConto and Pollard, 2016). However, uncertainties still exist surrounding how much sea-level rise Antarctica will contribute to the global average, how fast ice will retreat, and where exactly it will be lost (Pollard and DeConto, 2009; Miller et al., 2012; IPCC, 2013; DeConto and Pollard, 2016). Although this study alone cannot answer those questions, results contained within still provide an important record of paleoenvironmental change in southern McMurdo Sound, and exists as an accessible proxy for evaluating future change in the region.

\subsection{Future work}

Attempts to establish a temperature signature from glacimarine sequences DO1A and DO3A has not be possible within the timeframe given for completing this MSc thesis. Future work on these deposits will focus on reconstructing changes in sea-surface temperatures based on a number of different approaches, including lipid biomarkers and geochemical analyses of benthic foraminifera. Reliable estimates of any changes in ocean temperature during deposition of DO1A and DO3A will provide an opportunity to better assess past environmental conditions in southern McMurdo Sound during times of significantly reduced ice volume. Results from this ongoing study will form part of a broader investigation into the response of Antarctic ice to past warmth in the region, enhancing what is understood about the behaviour of the West Antarctic Ice Sheet and its potential contribution to future eustatic sea level rise. 


\section{$\underline{\text { References }}$}

Abbott, S. T. (1997). Foraminiferal paleobathymetry and mid-cycle architecture of midPleistocene depositional sequences, Wanganui Basin, New Zealand: PALAIOS, v. 12, n. 3, p. $267-281$.

Abbott, S. T., and Carter, R. M. (1994). The sequence architecture of mid-Pleistocene (c. 1.10.4 Ma) cyclothems from New Zealand: facies development during a period of orbital control on sea-level cyclicity. Orbital forcing and cyclic sequences, p. 367-394.

Aitken, A.R., Wilson, G.S., Jordan, T., Tinto, K., and Blakemore, H. (2012). Flexural controls on late Neogene basin evolution in southern McMurdo Sound, Antarctica. Global and Planetary Change, v. 80, n. n/a, p. 99-112.

Amsler, M.O., Huang, Y.M., Engl, W., McClintock, J.B., and Amsler, C.D. (2015). Abundance and diversity of gastropods associated with dominant subtidal macroalgae from the western Antarctic Peninsula. Polar Biology, v. 38, n. 8, p. 1171-1181.

Anderson, J. B. (1975), Ecology and distribution of foraminifera in the Weddell Sea of Antarctica: Micropaleontology, v. 21, n. 1, p. 69-96.

Anderson, J. B., Brake, C., Domack, E., Myers, N., and Wright, R. (1983), Development of a polar glacial-marine sedimentation model from Antarctic Quaternary deposits and glaciological information, Glacial-marine sedimentation, Springer, p. 233- 264.

Anderson, J. B., Kennedy, D. S., Smith, M. J., and Domack, E. W. (1991), Sedimentary facies associated with Antarctica's floating ice masses: Geological Society of America Special Papers, v. 261, n. n/a, p. 1-26.

Anderson, J.T., Wilson, G.S., Fink, D., Lilly, K., Levy, R.H., and Townsend, D. (2017). Reconciling marine and terrestrial evidence for post LGM ice sheet retreat in southern McMurdo Sound, Antarctica. Quaternary Science Reviews, v. 157, n. n/a, p.1-13.

Balham, R.W., Wheeler, R. H., Allen, A. D., Gibson, G., and Willis, I.A.G. (1960). Immediate Report on the Victoria University of Wellington Antarctic Expedition 1959-60: VUWAE 3. Victoria University of Wellington. 
Bamber, J.L., Riva, R.E., Vermeersen, B.L., and LeBrocq, A.M. (2009). Reassessment of the potential sea-level rise from a collapse of the West Antarctic Ice Sheet. Science, v. 324, n. 5929), p. 901-903.

Barrett, P. J. (1975a). Characteristics of pebbles from Cenozoic marine glacial sediments in the Ross Sea (DSDP Sites 270-274) and the South Indian Ocean (Site 268): Initial Reports of the Deep Sea Drilling Project, v. 28, n. n/a, p. 769-784.

Barrett, P. J. (1975b). Textural characteristics of Cenozoic preglacial and glacial sediments at Site 270, Ross Sea, Antarctica: Initial Reports of the Deep Sea Drilling Project, v. 28, n. n/a, p. $757-767$.

Barrett, P. J. (1986). Antarctic Cenozoic History from the MSSTS-1 drillhole, McMurdo Sound. DSIR Bulletin v. 237, n. 174

Barrett, P.J. (1989). Antarctic Cenozoic history from the CIROS-1 drillhole, McMurdo Sound. Department of Scientific and Industrial Research Publishing.

Barrett, P.J. (2009). Cenozoic climate and sea level history from glacimarine strata off the Victoria Land coast, Cape Roberts Project, Antarctica. Glacial sedimentary processes and products: International Association of Sedimentologists Special Publication, v. 39, n. n/a, p. 259-287.

Barrett, P. J. (2013). Resolving views on Antarctic Neogene glacial history-the Sirius debate. Earth and Environmental Science: Transactions of the Royal Society of Edinburgh, v. 104, n. n/a, p. 31-53 (2013).

Barrett, P. J., Elston, D. P., Harwood, D. M., McKelvey, B. C., and Webb, P. N. (1987). Mid-Cenozoic record of glaciation and sea level change on the margin of the Victoria Land Basin, Antarctica. Geology, v. 15, n. n/a, p. 634-637

Barrett, P. J., \& Hambrey, M. J. (1992). Plio-Pleistocene sedimentation in Ferrar Fiord, Antarctica. Sedimentology, 39(1), pp. 109-123.

Barrett, P.J., Henrys, S.A., Bartek, L.R., Brancolini, G., Busetti, M., Davey, F.J., Hannah, M.J., and Pyne, A.R. (1995). Geology of the margin of the Victoria Land basin off Cape Roberts, southwest Ross Sea. Geology and seismic stratigraphy of the Antarctic margin, pp.183-207. 
Barrett, P.J., and McKelvey, B.C. (1986). Stratigraphy. Antarctic Cenozoic history from the MSSTS-1 drillhole, McMurdo Sound. DSIR bulletin, v. 237, n. 174, p. 9-52

Barrett, P.J., Sarti, M. and Wise, S.W. (2000). Studies from the Cape Roberts Project, Ross Sea, Antarctica, Initial reports on CRP-3. Terra Antartica, v. 7, n. 1.

Barrett, P.J., and Treves, S.B. (1981). Sedimentology and petrology of core from DVDP 15, western McMurdo Sound. Dry valley drilling project, p. 281-314.

Bartoli, G., Hönisch, B., and Zeebe, R. E. (2011). Atmospheric CO2 decline during the Pliocene intensification of Northern Hemisphere glaciations. Paleoceanography, v. 26, n. 4.

Bateman, M.D., Carr, A.S., Dunajko, A.C., Holmes, P.J., Roberts, D.L., McLaren, S.J., Bryant, R.G., Marker, M.E., and Murray-Wallace, C.V. (2011). The evolution of coastal barrier systems: a case study of the Middle-Late Pleistocene Wilderness barriers, South Africa. Quaternary Science Reviews, v. 30, n. 1, p. 63-81.

Benn, D. I., and Evans, D. J. A. (2010). Glaciers \& glaciation. Hodder Education: London.

Blanchon, P., Eisenhauer, A., Fietzke, J., and Liebetrau, V. (2009). Rapid sea-level rise and reef back-stepping at the close of the last interglacial highstand. Nature, v. 458, n. 7240, p. 881884.

Blott, S. J. (2010). GRADISTAT: A Grainsize Distribution and Statistics Package for the Analysis of unconsolidated Sediments by Sieving or Laser Granulometer: Berkshire, UK, Kenneth Pye Associates Ltd. Computer Programme. References 112

Blott, S. J., and Pye, K. (2001). GRADISTAT: a grainsize distribution and statistics package for the analysis of unconsolidated sediments: Earth Surface Processes and Landforms, v. 26, n. 11 , p. $1237-1248$.

Boggs Jr, S. (2011). Siliciclastic Marine Environments, Principles of Seimentology and Stratigraphy: Upper Saddle River, New Jersey, Pearson Prentice Hall, p. 280-307.

Bowen, D.Q. (2010). Sea level 400000 years ago (MIS 11): analogue for present and future sea-level?. Climate of the Past, v. 6, n. 1, p. 19-29. 
Brierley, C. M., Fedorov, A. V., Liu, Z., Herbert, T. D., Lawrence, K. T., and LaRiviere, J. P. (2009). Greatly expanded tropical warm pool and weakened Hadley circulation in the early Pliocene: Science, v. 323, n. 5922, p. 1714-1718.

Brigham-Grette, J., \& Carter, L. D. (1992). Pliocene marine transgressions of northern Alaska: circumarctic correlations and paleoclimatic interpretations. Arctic, p. 74-89.

Buckeridge, J. S. (1989). Marine invertebrates from late Cainozoic deposits in the McMurdo Sound region, Antarctica. Journal of the Royal Society of New Zealand, v. 19, n. 3, p. 333-342.

Bull, C., Wheeler, R. H., Willis, I. A. G., Blank, H. R., and Cooper, R. A. (1961) Report on the Victoria University Antarctic Expedition 1960-61: VUWAE 4. Victoria University of Wellington.

Cape Roberts Science Team. (1999). Studies from the Cape Roberts Project: initial report on CRP-2/2A, Ross Sea, Antarctica. Terra Antartica.

Capron, E., Govin, A., Stone, E.J., Masson-Delmotte, V., Mulitza, S., Otto-Bliesner, B., Rasmussen, T.L., Sime, L.C., Waelbroeck, C., and Wolff, E.W. (2014). Temporal and spatial structure of multi-millennial temperature changes at high latitudes during the Last Interglacial. Quaternary Science Reviews, v. 103, n. n/a, p. 116-133.

Carter, R. M., \& Naish, T. R. (1998). A review of Wanganui Basin, New Zealand: global reference section for shallow marine, Plio-Pleistocene $(2.5-0 \quad \mathrm{Ma})$ cyclostratigraphy. Sedimentary Geology, v. 122, n. 1, p. 37-52.

Clarke, A., Griffiths, H.J., Linse, K., Barnes, D.K. and Crame, J.A. (2007). How well do we know the Antarctic marine fauna? A preliminary study of macroecological and biogeographical patterns in Southern Ocean gastropod and bivalve molluscs. Diversity and Distributions, v. 13, n. 5 , p. $620-632$.

Cole, J. W., and Ewart, A. (1968). Contributions to the volcanic geology of the Black Island, Brown Peninsula, and Cape Bird areas, McMurdo sound, Antarctica. New Zealand Journal of Geology and Geophysics, v. 11, n. 4, p. 793-828.

Cole, J. W., Kyle, P. R., and Neall, V. E. (1971). Contributions to Quaternary geology of Cape Crozier, White Island and Hut Point Peninsula, McMurdo Sound Region, Antarctica. New Zealand Journal of Geology and Geophysics, v. 14, n. 3, p. 528-546. 
Colmenero-Hidalgo, E., Flores, J. A., Sierro, F. J., Bárcena, M. A., Löwemark, L., Schönfeld, J., and Grimalt, J. O. (2004). Ocean surface water response to short-term climate changes revealed by coccolithophores from the Gulf of Cadiz (NE Atlantic) and Alboran Sea (W Mediterranean). Palaeogeography, Palaeoclimatology, Palaeoecology, v. 205, n. 3, p. 317-336.

Colville, E.J., Carlson, A.E., Beard, B.L., Hatfield, R.G., Stoner, J.S., Reyes, A.V., and Ullman, D.J. (2011). Sr-Nd-Pb isotope evidence for ice-sheet presence on southern Greenland during the Last Interglacial. Science, v. 333, n. 6042, p. 620-623.

Cook, C.P., Van De Flierdt, T., Williams, T., Hemming, S.R., Iwai, M., Kobayashi, M., Jimenez-Espejo, F.J., Escutia, C., González, J.J., Khim, B.K., and McKay, R.M. (2013). Dynamic behaviour of the East Antarctic ice sheet during Pliocene warmth. Nature Geoscience, v. 6, n. 9, p. 765-769.

Cooper, A.F., Adam, L.J., Coulter, R.F., Eby, G.N., and McIntosh, W.C. (2007). Geology, geochronology and geochemistry of a basanitic volcano, White Island, Ross Sea, Antarctica. Journal of Volcanology and Geothermal Research, v. 165, n. 3, p. 189-216.

Crampton, J.S., Cooper, R.A., Sadler, P.M., and Foote, M. (2016). Greenhouse- ${ }^{-}$icehouse transition in the Late Ordovician marks a step change in extinction regime in the marine plankton. Proceedings of the National Academy of Sciences, v. 113, n. 6, p. 1498-1503.

Crowley, T. J. (1991), Modelling Pliocene Warmth: Quaternary Science Reviews, v. 10, n. n/a, p. $275-282$.

Dahl-Jensen, D., Albert, M.R., Aldahan, A., Azuma, N., Balslev-Clausen, D., Baumgartner, M., Berggren, A.M., Bigler, M., Binder, T., Blunier, T., and Severinghaus, J.P. (2013). Eemian interglacial reconstructed from a Greenland folded ice core. Nature, v. 493, n. 7433, p. 489.

David, S. T. W. E., Priestley, R. E. (1914). Glaciology, Physiography, Stratigraphy, and Tectonic Geology of South Victoria Land. Reports on the Scientific Investigations British Antarctic Expedition 1907-09, Geology v. 1, p 319.

Dayton, P.K., Newman, W.A., and Oliver, J. (1982). The vertical zonation of the deep-sea Antarctic acorn barnacle, Bathylasma corolliforme (Hoek): experimental transplants from the shelf into shallow water. Journal of Biogeography, pp.95-109. 
DeConto, R. M., and Pollard, D. (2016). Contribution of Antarctica to past and future sea-level rise. Nature, v. 531, n. 7596, p. 591-597.

Denton, G.H., and Hughes, T.J. (2002). Reconstructing the Antarctic ice sheet at the Last Glacial Maximum. Quaternary Science Reviews, v. 21, n. 1, p. 193-202.

Denton, G.H., and Marchant, D.R. (2000). The geologic basis for a reconstruction of a grounded ice sheet in McMurdo Sound, Antarctica, at the last glacial maximum. Geografiska Annaler: Series A, Physical Geography, v. 82, n. 2-3, p. 167-211.

Denton, G. H., Prentice, M. L., Kellogg, D. E., and Kellogg, T. B. (1984). Late Tertiary history of the Antarctic ice sheet; evidence form the dry valleys. Geology, v. 12, n. n/a, p. 263-267.

Denton, G.H., Sugden, D.E., Marchant, D.R., Hall, B.L., and Wilch, T.I. (1993). East Antarctic Ice Sheet sensitivity to Pliocene climatic change from a Dry Valley perspective. Geografiska Annaler, v. 75A, n. n/a, p. 155-204.

Domack, E. W., Jacobson, E. A., Shipp, S., and Anderson, J. B. (1999). Late PleistoceneHolocene retreat of the West Antarctic Ice-Sheet system in the Ross Sea: Part 2sedimentologic and stratigraphic signature: Geological Society of America Bulletin, v. 111, n. 10, p. 1517-1536.

Domack, E.W., Jull, A.T., Anderson, J.B., Linick, T.W., and Williams, C.R. (1989). Application of tandem accelerator mass-spectrometer dating to late Pleistocene-Holocene sediments of the East Antarctic continental shelf. Quaternary Research, v. 31, n. 2, p. 277-287.

Donahue, D.J., Linick, T.W., and Jull, A.T. (1990). Isotope-ratio and background corrections for accelerator mass spectrometry radiocarbon measurements. Radiocarbon, v. 32, n. 02, p. 135-142.

Dowdeswell, J., Elverhfi, A., and Spielhagen, R. (1998). Glacimarine sedimentary processes and facies on the Polar North Atlantic margins: Quaternary Science Reviews, v. 17, n. 1, p. 243-272.

Dowsett, H., Barron, J., and Poore, R. (1996). Middle Pliocene sea surface temperatures: a global reconstruction. Marine Micropaleontology, v. 27, n. 1-4, p. 13-25.

Dowsett, H. J., and Cronin, T. M. (1990). High eustatic sea level during the middle Pliocene: Evidence from the southeastern US Atlantic Coastal Plain. Geology, v. 18, n. 5, p. 435-438. 
Dowsett, H. J., Robinson, M. M., Haywood, A. M., Hill, D. J., Dolan, A. M., Stoll, D. K., Chan, W.-L., Abe-Ouchi, A., Chandler, M. A., Rosenbloom, N. A., Otto-Bliesner, B. L., Bragg, F. J., Lunt, D. J., Foley, K. M., and Riesselman, C. R. (2012). Assessing confidence in Pliocene sea surface temperatures to evaluate predictive models: Nature Climate Change, v. 2, n. 5, p. 365371.

Dunbar, G.B., Naish, T.R., Barrett, P.J., Fielding, C.R., and Powell, R.D. (2008). Constraining the amplitude of late Oligocene bathymetric changes in Western Ross Sea during orbitallyinduced oscillations in the East Antarctic Ice Sheet:(1) Implications for glacimarine sequence stratigraphic models. Palaeogeography, Palaeoclimatology, Palaeoecology, v. 260, n. 1, p. 5065.

Duplessy, J.C., Roche, D.M., and Kageyama, M. (2007). The deep ocean during the last interglacial period. Science, v. 316, n. 5821, p. 89-91.

Dutton, A., and Lambeck, K. (2012). Ice volume and sea level during the last interglacial. Science, v. 337, n. 6091, p. 216-219.

Dwyer G.S., and Chandler M.A. (2009). Mid-Pliocene sea level and continental ice volume based on coupled benthic $\mathrm{Mg} / \mathrm{Ca}$ palaeotemperatures and oxygen isotopes: Royal Society of London Philosophical Transactions, ser. A, v. 367 p. 157-168, doi:10.1098/rsta.2008.0222.

Eggers, A. J. (1979). Scallop Hill Formation, Brown Peninsula, McMurdo Sound, Antarctica. New Zealand Journal of Geology and Geophysics, v. 22, n. 3, p. 353-361.

Evans, J., Dowdeswell, J., Grobe, H., Niessen, F., Stein, R., Hubberten, H.-W., and Whittington, R. (2002). Late Quaternary sedimentation in Kejser Franz Joseph Fjord and the continental margin of east Greenland: Geological Society, London, Special Publications, v. 203, n. n/a, p. 149-179.

Eyles, N., and Eyles, C. H. (1992). Glacial depositional systems: Facies Models: response to sea level change, Walker, RG and James, NP (ed.) St. John's: Geological Association of Canada, p. 73-100.

Eyles, C. H., and Lagoe, M. B. (1990). Sedimentation patterns and facies geometries on a temperate glacially-influenced continental shelf: the Yakataga Formation, Middleton Island, Alaska: Geological Society, London, Special Publications, v. 53, n. 1, p. 363-386. 
Fedorov, A. V., Dekens, P. S., McCarthy, M., Ravelo, A. C., Barreiro, M., Pacanowski, R. C., \& Philander, S. G. (2006). The Pliocene paradox (mechanisms for a permanent El Niño). Science, v. 312, n. 5779, p. 1485-1489.

Fielding, C, Naish, T.R., Woolfe, K., Lavelle, M., and Krisseck, L., (2000). Sequence stratigraphy of CRP-2/2A. Terra Antartica 7: p. 323-338.

Fielding, C.F., Whittaker, J., Henrys, S., Wilson, T., and Naish, T.R., (2008). Seismic facies and stratigraphy of the Cenozoic succession in McMurdo Sound, Antarctica: implications for tectonic, climatic and glacial history. Paleoclimatology, Paleogeography, Paleoecology v. 260, n. $1-2$, p. $8-29$.

Flores, J. A., and Sierro, F. J. (2007). Pronounced mid-Pleistocene southward shift of the Polar Front in the Atlantic sector of the Southern Ocean. Deep Sea Research Part II: Topical Studies in Oceanography, v. 54, n. 21, p. 2432-2442

Florindo, F., Francis, J., Harwood, D.M., Levy, R.H., Naish, T.R., Niessen, F., Powell, R.D., and Wilson, G.S., (2003). The ANDRILL Initiative: Stratigraphic Drilling for Climatic and Tectonic History in Antarctica. Terra Antartica Reports 9: p. 123-126.

Francis, J.E., and Hill, R.S. (1996). Fossil plants from the Pliocene Sirius Group, Transantarctic Mountains: Evidence for climate from growth rings and fossil leaves. Palaios, v. 11, n. n/a, p. 389-396.

Golledge, N.R., Kowalewski, D.E., Naish, T.R., Levy, R.H., Fogwill, C.J., and Gasson, E.G., (2015). The multi-millennial Antarctic commitment to future sea-level rise. Nature, v. 526, n. 7573 , p. 421-425.

Goodwin, I.D., (1993). Holocene deglaciation, sea-level change, and the emergence of the Windmill Islands, Budd Coast, Antarctica. Quaternary Research, v. 40, n. 1, p. 55-69.

Grant, K.M., Rohling, E.J., Bar-Matthews, M., Ayalon, A., Medina-Elizalde, M., Ramsey, C.B., Satow, C. and Roberts, A.P., 2012. Rapid coupling between ice volume and polar temperature over the past 150,000 [thinsp] years. Nature, v. 491, n. 7426, p. 744-747.

Hart, J. K., and Roberts, D. H., (1994) Criteria to distinguish between subglacial glaciotectonic and glaciomarine sedimentation, I. Deformation styles and sedimentology: Sedimentary Geology, v. 91, n. 1, p. 191-213. 
Harwood, D.M., Webb, P.-N., McKelvey, B.C., Mercer, J.H., and Stott, L.D. (1983). Late Neogene and Paleogene diatoms in high elevation glacigene sediments, Transantarctic Mountains. The Geological Society of America, Annual Meeting, v. 16, n. 6, p. 592.

Harwood, D., Florindo, F., Talarico, F., Levy, R., Kuhn, G., Naish, T., Niessen, F., Powell, R., Pyne, A., and Wilson, G., (2009). Antarctic drilling recovers stratigraphic records from the continental margin. Eos v. 90, n. 11, p. 90-91.

Harwood, D., Levy, R., Cowie, J., Florindo, F., Naish, T., Powell, R., and Pyne, A., (2006). Deep drilling with the ANDRILL program in Antarctica. Scientific Drilling v. 1, n. 3, p. 4345 .

Hayden, T., Kominz, M., Powars, D. S., Edwards, L. E., Miller, K. G., Browning, J. V., and Kulpecz, A. A. (2008). Impact effects and regional tectonic insights: Backstripping the Chesapeake Bay impact structure. Geology, v. 36, n.4, p. 327-330.

Hayes, D., and Frakes, L., (1975). General synthesis, deep sea drilling project leg 28: Initial Reports of the Deep Sea Drilling Project, v. 28, n. n/a, p. 919-942.

Hayward, B. W., Grenfell, H. R., Reid, C. M., and Hayward, K. A. (1999). Recent New Zealand shallow-water benthic foraminifera: Taxonomy, ecologic distribution, biogeography, and use in paleoenvironmental assessment: Institute of Geological and Nuclear Sciences monograph 21, Lower Hutt, New Zealand, p. 264.

Hayward, B.W., Grenfell, H.R., Sabaa, A.T., and Neil, H.L. (2007). Factors influencing the distribution of Subantarctic deep-sea benthic foraminifera, Campbell and Bounty Plateaux, New Zealand. Marine Micropaleontology, v. 62, n. 3, p. 141-166.

Haywood, A., Sellwood, B., and Valdes, P. (2000). Regional warming: Pliocene (3 Ma) paleoclimate of Europe and the Mediterranean: Geology, v. 28, n. 12, p. 1063-1066.

Haywood, A. M., and Valdes, P. J. (2004). Modelling Pliocene warmth: contribution of atmosphere, oceans and cryosphere: Earth and Planetary Science Letters, v. 218, n. 3, p. 363377.

Hearty, P.J., Kindler, P., Cheng, H., and Edwards, R.L. (1999). A+ 20 m middle Pleistocene sea-level highstand (Bermuda and the Bahamas) due to partial collapse of Antarctic ice. Geology, v. 27, n. 4, p. 375-378. 
Hearty, P.J. (2002). Revision of the late Pleistocene stratigraphy of Bermuda. Sedimentary Geology, v. 153, n. 1, p. 1-21.

Herbert, T. D., Peterson, L. C., Lawrence, K. T., and Liu, Z. (2010). Tropical ocean temperatures over the past 3.5 million years. Science, v. 328, n. 5985, p. 1530-1534.

Hill, D. J., Haywood, A. M., Lunt, D. J., Hunter, S. J., Bragg, F. J., Contoux, C., Stepanek, C., Sohl, L., Rosenbloom, N. A., Chan, W. L., Kamae, Y., Zhang, Z., Abe-Ouchi, A., Chandler, M. A., Jost, A., Lohmann, G., Otto-Bliesner, B. L., Ramstein, G., and Ueda, H. (2014), Evaluating the dominant components of warming in Pliocene climate simulations: Climate of the Past, v. 10, n. 1, p. 79-90.

Horgan, H., Naish, T., Bannister, S., Balfour, N., and Wilson, G. (2005). Seismic stratigraphy of the Plio-Pleistocene Ross Island flexural moat-fill: a prognosis for ANDRILL Program drilling beneath McMurdo-Ross Ice Shelf. Global and planetary change, v. 45, n. 1, p. 83-97.

Hornibrook, N. d. B., Brazier, R. C., and Strong, C. P., (1989). Manual of New Zealand Permian to Pleistocene foraminiferal biostratigraphy.: New Zealand Geological Survey Palaeontological Bulletin, v. 34, n. 1, p. 178.

Ishman, S. E. (1991). Benthic foraminiferal ecology of the Antarctic Peninsula Pacific Coast. in Thomson, M., Crame, J., and Thomson, J. (ed.): Geological Evolution of Antarctica. Cambridge University Press.

Ishman, S. E., and Rieck, H. J. (1992). A Late Neogene Antarctic Glacio-Eustatic Record, Victoria Land Basin: Antarctic Research Series, v. 56, n. n/a, p. 327-347.

Ishman, S. E., and Szymcek, P., 2003, Foraminiferal distributions in the former Larsen-A ice shelf and Prince Gustav Channel region, Eastern Antarctic Peninsula margin: A baseline for Holocene paleoenvironmental change, 84 Antarctic Peninsula Climate Variability: Antarctic Research Series, v. 79,n. n/a, p. 239-260.

Ishman, S. E., and Webb, P. N. (1988). Late Neogene Benthic Foraminifera from the Victoria Land Basin Margin, Antarctica: Application to Glacio-Eustatic and tectonic events, In Benthos '86, Rev, Paleobio., Spec. vol.2, 523-551.

Israelson, C., and Wohlfarth, B. (1999). Timing of the last-interglacial high sea level on the Seychelles Islands, Indian Ocean. Quaternary Research, v. 51, n. 3, p. 306-316. 
Kaufman, D.S., and Brigham-Grette, J. (1993). Aminostratigraphic correlations and paleotemperature implications, Pliocene-Pleistocene high-sea-level deposits, northwestern Alaska. Quaternary Science Reviews, v. 12, n. 1, p. 21-33.

Kellogg, T.B., Kellogg, D.E., and Stuiver, M. (1990): Late Quater- nary history of the southwestern Ross Sea: Evidence from de- bris bands on the McMurdo Ice Shelf, Antarctica. In: Elliot, D.H. (ed.): Contributions to Antarctic Research I, American Geophysical Union, Antarctic Research Series, v. 50, n. n/a, p. 25-56.

Kennett, J. P. (1966). Foraminiferal evidence of a shallow calcium carbonate solution boundary, Ross Sea, Antarctica. Science, v. 153, n. n/a, p. 191-193.

Kennett, J.P. (1968). The Fauna of the Ross Sea: Part 6: Ecology and Distribution of Foraminifera. Department of Scientific and Industrial Research Bulletin, v. 186, n. n/a, p. 147.

Kennett, J., and Shackleton, N. (1976). Oxygen isotopic evidence for the development of the psychrosphere 38 Myr ago: Nature, v. 260, n. 5551, p. 513-515.

Kennett, J. P. (1977). Cenozoic evolution of Antarctic glaciation, the circum-Antarctic Ocean, and their impact on global paleoceanography: Journal of geophysical research, v. 82, o. 27, p. 3843-3860.

Kennett, J. P., amd Hodell, D. A. (1995). Stability or instability of Antarctic ice sheets during warm climates of the Pliocene. GSA Today, v. 5, n. 1, p. 10-13.

Kindler, P., and Hearty, P.J. (2000). Elevated marine terraces from Eleuthera (Bahamas) and Bermuda: sedimentological, petrographic and geochronological evidence for important deglaciation events during the middle Pleistocene. Global and Planetary Change, v. 24, n. 1, p. 41-58.

Kleiven, H. F., Jansen, E., Curry, W. B., Hodell, D. A., and Venz, K. (2003). Atlantic Ocean thermohaline circulation changes on orbital to suborbital timescales during the midPleistocene. Paleoceanography, v. 18, n. 1, p. 801-813.

Kopp, R.E., Simons, F.J., Mitrovica, J.X., Maloof, A.C., and Oppenheimer, M. (2009). Probabilistic assessment of sea level during the last interglacial stage. Nature, v. 462, n. 7275, p. 863-867. 
Kopp, R.E., Simons, F.J., Mitrovica, J.X., Maloof, A.C., and Oppenheimer, M. (2013). A probabilistic assessment of sea level variations within the last interglacial stage. Geophysical Journal International, v. 193, n. 2, p. 711-716.

Krissek, L., Browne, G., Carter, L., Cowan, E., Dunbar, G., McKay, R., Naish, T., Powell, R., Reed, J., Wilch, T., and the ANDRILL-MIS Science Team, (2007). Sedimentology and stratigraphy of AND-1B Core, ANDRILL McMurdo Ice Shelf Project, Antarctica. Terra Antartica, v. 14, n. 3, p. 185-222.

Kyle, P.R., (1990). A. McMurdo Volcanic Group Western Ross embayment. Volcanoes of the Antarctic plate and southern Oceans, p. 18-145.

Kyle, P. R., Adams, J., and Rankin, P. C. (1979). Geology and petrology of the McMurdo Volcanic Group at Rainbow Ridge, Brown Peninsula, Antarctica. Geological Society of America Bulletin, v. 90, n. (7, p. 676-688.

Laskar, J. (1990). The chaotic motion of the solar system: A numerical estimate of the size of the chaotic zones. Icarus v 88, n. 2 p. 266-291.

Lear, C. H., Rosenthal, Y., Coxall, H. K., and Wilson, P. A. (2004). Late Eocene to early Miocene ice sheet dynamics and the global carbon cycle. Paleoceanography, v. 1, n. 4.

Leckie, R. M., and Webb, P. N. (1983). Late Oligocene - early Miocene glaicial record of the Ross Sea, Antarctica: Evidence from DSDP site 270: Geology, v. 11, n. n/a, p. 578-582.

Levy, R., Cody, R., Crampton, J., Fielding, C., Golledge, N., Harwood, D., Henrys, S., Mckay, R., Naish, T., Ohneiser, C. and Wilson, G. (2012). Late Neogene climate and glacial history of the Southern Victoria Land coast from integrated drill core, seismic and outcrop data. Global and Planetary Change, v. 80, n. n/a, p. 61-84.

Li, C., von Storch, J.S., and Marotzke, J. (2013). Deep-ocean heat uptake and equilibrium climate response. Climate Dynamics, v. 40, n. 5-6, p. 1071-1086.

Linse, K., Griffiths, H.J., Barnes, D.K., and Clarke, A. (2006). Biodiversity and biogeography of Antarctic and sub-Antarctic mollusca. Deep Sea Research Part II: Topical Studies in Oceanography, v. 53, n. 8, p. 985-1008.

Lipps, J. H. (1979). Ecology and Paleoecology of Planktic Foraminifera, in Foraminifera Ecology and Paleoecology SEPM Short Course No. 6 Houston 1979, p. 62-104. 
Lisiecki, L. E., and M. E. Raymo (2005). A Pliocene-Pleistocene stack of 57 globally distributed benthic $\delta^{18} \mathrm{O}$ records. Paleoceanography, v. 20, n. 1, PA1003.

Lønne, I. (1995). Sedimentary facies and depositional architecture of ice-contact glaciomarine systems. Sedimentary Geology, v. 98, n. 1, p. 13-43.

Lunt, D.J., Jones, T.D., Heinemann, M., Huber, M., LeGrande, A., Winguth, A., Loptson, C., Marotzke, J., Roberts, C.D., Tindall, J., and Valdes, P. (2012). "A model-data comparison for a multi-model ensemble of early Eocene atmosphere-ocean simulations: EoMIP." Climate of the Past v. 8, n. n/a, p. 1717-1736

Mackiewicz, N. E., Powell, R. D., Carlson, P. R., and Molnia, B. F. (1984). Interlaminated iceproximal glacimarine sediments in Muir Inlet, Alaska: Marine Geology, v. 57, n. 1, p. 113-147.

Masson-Delmotte, V., M. Schulz, A. Abe-Ouchi, J. Beer, A. Ganopolski, J.F. González Rouco, E. Jansen, K. Lambeck, J. Luterbacher, T. Naish, T. Osborn, B. Otto-Bliesner, T. Quinn, R. Ramesh, M. Rojas, X. Shao, and A. Timmermann. (2013). Information from Paleoclimate Archives. In: Climate Change 2013: The Physical Science Basis. Contribution of Working Group I to the Fifth Assessment Report of the Intergovernmental Panel on Climate Change [Stocker, T.F., D. Qin, G.-K. Plattner, M. Tignor, S.K. Allen, J. Boschung, A. Nauels, Y. Xia, V. Bex and P.M. Midgley (eds.)]. Cambridge University Press, Cambridge, United Kingdom and New York, NY, USA, pp. 383-464, doi:10.1017/CBO97811074015324.013.

Marchant, D.R., Denton, G.H., Swisher III, C.C, amd Potter Jr., N. (1996). Late Cenozoic Antarctic paleoclimate reconstructed from volcanic ashes in the Dry Valleys region of southern Victoria Land. Geological Society of America Bulletin, v. 108, n. n/a, p.181-194.

Mayewski, P.A. (1975). Glacial geology and Late Cenozoic history of the Transantarctic Mountains, Antarctica. Institute of Polar Studies report v.56, The Ohio State University.

McFarlane, D.A., and Lundberg, J. (2002). A middle Pleistocene age and biogeography for the extinct rodent Megalomys curazensis from Curaçao, Netherlands Antilles.

McIntyre, A. (1967). Coccoliths as paleoclimatic indicators of Pleistocene glaciation. Science, v. 158, n. 3806, p. 1314-1317. 
McKay, N.P., Overpeck, J.T., and Otto-Bliesner, B.L. (2011). The role of ocean thermal expansion in Last Interglacial sea level rise. Geophysical Research Letters, v. 38, n. 14.

McKay, R., Barrett, P., Harper, M., and Hannah, M. (2008). Atmospheric transport and concentration of diatoms in the Allan Hills, Transantarctic Mountains. Palaeogeography, Palaeoclimatology, Palaeoecology v. 260, n. n/a, p. 245-261.

McKay, R., Browne, G., Carter, L., Cowan, E., Dunbar, G., Krissek, L., Naish, T., Powell, R., Reed, J., Talarico, F., and Wilch, T. (2009), The stratigraphic signature of the late Cenozoic Antarctic Ice Sheets in the Ross Embayment: GSA Bulletin, v. 121, n. 11-12, p. 1537-1561.

McKay, R., Naish, T., Carter, L., Riesselman, C., Dunbar, R., Sjunneskog, C., Winter, D., Sangiorgi, F., Warren, C., Pagani, M., and Schouten, S. (2012a). Antarctic and Southern Ocean influences on Late Pliocene global cooling. Proceedings of the National Academy of Sciences, v. 109, n. 17, p. 6423-6428.

McKelvey, B.C., Webb, P.N., Harwood, D.M. and Mabin, M.C.G. (1991). The Dominion Range Sirius Group: a record of the Late Pliocene-Early Pleistocene Beardmore Glacier. In: Thompson, M.R.A., Crame, J.A. and Thompson, J.W. (ed.), Geological Evolution of Antarctica. Cambridge, Cambridge University Press, p.675- 682.

McGinnis, L. D., Torii, T., and Webb, P. N. (1972). Dry Valley Drilling Project; three nations are studying the subsurface in the McMurdo Sound region Antarctic Journal of the United States, v. 7, n. 3, p. 53-56

McGinnis, L.D. (1981). Dry Valley Drilling Project Antarctic Research Series. American Geophysical Union, v. 33, p. 465

McManus, J., Oppo, D., Cullen, J., and Healey, S. (2003). Marine Isotope Stage 11 (MIS 11): Analog for Holocene and future climate?. Geophysical monograph, v. 137, n. n/a, p. 69-85.

McKnight, W.M. (1962). The distribution of foraminifera off parts of the Antarctic coast. Bulletin of American Paleontology, v. 44, n. 201, p. 65-158

Melhuish, A., Henrys, S.A., Bannister, S., and Davey, F.J. (1995). Seismic profiling adjacent to Ross Island: Constraints on late Cenozoic stratigraphy and tectonics. Terra Antartica, v. 2, n. 2, p. 127-136. 
Mercer, J. H. (1968). Glacial geology of the Reedy Glacier area, Antarctica. Geological Society of America Bulletin, v. 79, n. 4, p/ 471-486.

Mercer, J. H. (1972). Some observations on the glacial geology of the Beardmore Glacier area. Antarctic geology and geophysics: Oslo, Universitetsforlaget, p. 427-433.

Mercer, J. H. (1978). West Antarctic ice sheet and CO2 greenhouse effect; a threat of disaster. Nature v. 271, n. n/a, p.321-325.

Milam, R. W., and Anderson, J. B. (1981). Distribution and ecology of recent benthic foraminifera of the Adelie-George V continental shelf and slope, Antarctica: Marine Micropaleontology, v. 6, n. n/a, p. 297-325.

Miller, K.G., Kominz, M.A., Browning, J.V., Wright, J.D., Mountain, G.S., Katz, M.E., Sugarman, P.J., Cramer, B.S., Christie-Blick, N., and Pekar, S.F. (2005). The Phanerozoic record of global sea-level change. science, v. 310, n. 5752, p. 1293-1298.

Miller, K. G., Wright, J. D., Browning, J. V., Kulpecz, A., Kominz, M., Naish, T. R., Cramer, B. S., Rosenthal, Y., Peltier, W. R., and Sosdian, S. (2012). High tide of the warm Pliocene: Implications of global sea level for Antarctic deglaciation: Geology, v. 4, no. 5, p. 407410.

Murray, J. W. (1991a). Ecology and distribution of planktonic foraminifera, in John J. Lee and O. Roger Anderson (eds.) Biology of Foraminifera, p. 368.

Naish, T. (1997). Constraints on the amplitude of late Pliocene eustatic sea-level fluctuations: new evidence from the New Zealand shallow-marine sediment record. Geology, v. 25, n. 12, p. 1139-1142.

Naish, T., and Kamp, P. J. (1997a). Sequence stratigraphy of sixth-order (41 ky) PliocenePleistocene cyclothems, Wanganui Basin, New Zealand: a case for the regressive systems tract: Geological Society of America Bulletin, v. 109, n. 8, p. 978-999.

Naish, T.R., Powell, R., Levy, R., and the ANDRILL-MIS Science Team, (2007a). Background to the ANDRILL McMurdo Ice Shelf Project, Antarctica. Terra Antartica v. 14, n. 3, p. 121130.

Naish, T.R., Powell, R., Levy, R., Florindo, F., Harwood, D., Kuhn, G., Niessen, F., Talarico, F., and Wilson, G., (2007b). A record of Antarctic climate and ice sheet history recovered. Eos Transactions, American Geophysical Union v. 88, n. 50, p. 557-558. 
Naish, T. R., Powell, R. D., Barrett, P. J., Levy, R. H., Henrys, S., Wilson, G. S., Krissek, L. A., Niessen, F., Pompilio, M., Ross, J., Schere, R., Talarico, F., Pyne, A., and the ANDRILLMIS science team. (2008). Late Cenozoic Climate History of the Ross Embayment from the AND-1B Drill Hole: Culmination of Three Decades of Antarctic Margin Drilling. In; Cooper, A. K., D. J. Barrett, H. Stagg, B. Storey, E. Stump, W. Wise, and the 10th ISAES editorial team , eds. (2008). Antarctica: A Keystone in a Changing World. Proceedings of the 10th 86 International Symposium on Antarctic Earth Sciences. Washington, DC: The National Academies Press, p. 71-78.

Naish, T., Powell, R., Levy, R., Wilson, G., Scherer, R., Talarico, F., Krissek, L., Niessen, F., Pompilio, M., Wilson, T., Carter, L., DeConto, R., Huybers, P., McKay, R., Pollard, D., Ross, J., Winter, D., Barrett, P., Browne, G., Cody, R., Cowan, E., Crampton, J., Dunbar, G., Dunbar, N., Florindo, F., Gebhardt, C., Graham, I., Hannah, M., Hansaraj, D., Harwood, D., Helling, D., Henrys, S., Hinnov, L., Kuhn, G., Kyle, P., Läufer, A., Maffioli, P., Magens, D., Mandernack, K., McIntosh, W., Millan, C., Morin, R., Ohneiser, C., Paulsen, T., Persico, D., Raine, I., Reed, J., Riesselman, C., Sagnotti, L., Schmitt, D., Sjunneskog, C., Strong, P., Taviani, M., Vogel, S., Wilch, T., and Williams, T., (2009). Obliquity-paced Pliocene West Antarctic ice Sheet oscillations. Nature, v. 458, n. n/a, p. 322-328

Naish, T., Levy, R., Powell, R., and MIS Science and Operations Team Members. (2006). Scientific Logistics Implementation Plan for the ANDRILL McMurdo Ice Shelf Project, Lincoln-NE, University of Nebraska-Lincoln, ANDRILL Contribution, v. 117,

Naish, T. R., and Wilson, G. S. (2009). Constraints on the amplitude of Mid-Pliocene (3.6-2.4 Ma) eustatic sea-level fluctuations from the New Zealand shallow-marine sediment record. Philosophical Transactions of the Royal Society of London A: Mathematical, Physical and Engineering Sciences, v. 367, n. 1886, p. 169-187.

Naish, T.R., Woolfe, K.J., Barrett, P.J., Wilson, G.S., Atkins, C., Bohaty, S.M., Bücker, C.J., Claps, M., Davey, F.J., Dunbar, G.B., and Dunn, A.G., 2001. Orbitally induced oscillations in the East Antarctic ice sheet at the Oligocene/Miocene boundary. Nature, v. 413, n. 6857, p. 719-723.

Naish, T., and Zwartz, D. (2012). Palaeoclimate: Looking back to the future: Nature Climate Change, v. 2, n. 5, p. 317-318. 
Ó Cofaigh, C., and Dowdeswell, J. A. (2001). Laminated sediments in glacimarine environments: diagnostic criteria for their interpretation: Quaternary Science Reviews, v. 20, n. 13 , p. 1411-1436.

Ó Cofaigh, C., Dowdeswell, J. A., and Grobe, H. (2001). Holocene glacimarine sedimentation, inner Scoresby Sund, East Greenland: the influence of fast-flowing ice-sheet outlet glaciers: Marine Geology, v. 175, n. 1, p. 103-129.

Olson, S.L., and Hearty, P.J. (2003). Probable extirpation of a breeding colony of Short-tailed Albatross (Phoebastria albatrus) on Bermuda by Pleistocene sea-level rise. Proceedings of the National Academy of Sciences, v. 100, n. 22, p. 12825-12829.

Olson, S.L., and Hearty, P.J. (2009). A sustained+21m sea-level highstand during MIS 11 (400ka): direct fossil and sedimentary evidence from Bermuda. Quaternary Science Reviews, v. 28, n. 3, p. 271-285.

Overpeck, J.T., Otto-Bliesner, B.L., Miller, G.H., Muhs, D.R., Alley, R.B., and Kiehl, J.T. (2006). Paleoclimatic evidence for future ice-sheet instability and rapid sea-level rise. Science, v. 311, n. 5768, p. 1747-1750.

Osterman, L. E., and Kellogg, T.B. (1979). Recent benthic foraminiferal distributions from the Ross Sea, Antarctica: Relation to ecologic and oceanographic conditions: Journal of Foraminiferal Research, v. 9, n. 3, p. 250-269.

Pagani, M., Liu, Z., LaRiviere, J., amd Ravelo, A. C. (2010). High Earth-system climate sensitivity determined from Pliocene carbon dioxide concentrations. Nature Geoscience, v. 3, n. 1 , p. 27-30.

Passchier, S., Fielding, C. R., Pekar, S., Panter, K., Harwood, D., Browne, G., Field, B., Krissek, L., Falk, C., and Florindo, F. (2010). Facies distribution of AND-2A and implications for ice dynamics during Early and Middle Miocene Climatic Optima and the Middle Miocene Climate Transition, In Kontar, K., Harwood, D. M., Florindo, F., and Fischbein, S., (eds.), 2010, ANDRILL Southern McMurdo Sound Project, Science Intergration Workshop Program and Abstracts. ANDRILL Contribution \#16, ANDRILL Science Management Office, Univ. of Nebraska, Lincoln, NE, p. 113. 
Patterson, M.O. and Ishman, S.E. (2012). Neogene benthic foraminiferal assemblages and paleoenvironmental record for McMurdo Sound, Antarctica. Geosphere, v. 8, n. 6, p. 13311341.

Patterson, M. O., R. McKay, T. Naish, C. Escutia, F. J. Jimenez-Espejo, M. E. Raymo, S. R. Meyers, L. Tauxe, H. Brinkhuis, and I. O. D. P. Expedition. (2014). Orbital forcing of the East Antarctic ice sheet during the Pliocene and Early Pleistocene. Nature Geoscience v. 7, n. 11, p. 841-847.

Pearson, T. H., and Rosenberg, R. (1978). Macrobenthic succession in relation to organic enrichment and pollution of the marine environment: Oceanography and Marine Biology Annual Review, v. 16, n. n/a, p. 229-311.

Pflum, C.E. (1966). The Distribution of Foraminifera in the Eastern Ross Sea, Amundsen Sea and Bellingshausen Sea, Antarctica. Bulletin of American Paleontology, v. 50, n. 226, p. 151209.

Pollard, D., and DeConto, R. (2009). Modelling West Antarctic ice sheet growth and collapse through the past five million years." Nature 458.7236. p. 329-332.

Poore, R.Z., and Dowsett, H.J. (2001). Pleistocene reduction of polar ice caps: Evidence from Cariaco Basin marine sediments. Geology, v. 29, n. 1, p. 71-74.

Powell, R. D. (1984). Glacimarine processes and inductive lithofacies modelling of ice shelf and tidewater glacier sediments based on Quaternary examples: Marine Geology, v. 57, n. 14, p. $1-52$.

Powell, R.D., and Domack, E.W. (2002). Glacimarine environments. Modern and Past Glacial Environments: Boston, Butterworth-Heinemann, p. 361-390

Powell, R. D., and Molnia, B. F. (1989). Glacimarine sedimentary processes, facies and morphology of the south-southeast Alaska shelf and fjords: Marine Geology, v. 85, n. 2-4, p. 359-390.

Powell, R., Krissek, L., and Van der Meer, J. (2000). Preliminary depositional environmental analysis of CRP-2/2A, Victoria Land Basin, Antarctica: palaeoglaciological and palaeoclimatic inferences: Terra Antarctica, v. 7, n. 3, p. 313-322. 
Quilty, P. G. (1985). Distribution of foraminiferids in sediments of Prydz Bay, Antarctica. Southen Australian Department of Mines and Energy Special Publication, v. 5, n. n/a, p. 329340.

Rathburn, A.E., Pichon, J.J., Ayress, M.A., and De Deckker, P. (1997). Microfossil and stableisotope evidence for changes in Late Holocene palaeoproductivity and palaeoceanographic conditions in the Prydz Bay region of Antarctica. Palaeogeography, Palaeoclimatology, Palaeoecology, v. 131, n. 3-4, p. 485-510.

Ravelo, A. C., and Andreasen, D. H. (2000). Enhanced circulation during a warm period. Geophysical Research Letters, v. 27, n. 7, p. 1001-1004.

Ravelo, A. C., Dekens, P. S., and McCarthy, M. (2006). Evidence for El Niño-like conditions during the Pliocene. GSA today, v. 16, n. 3, p. 4.

Raymo, M. E., Mitrovica, J. X., O’Leary, M. J., DeConto, R. M., and Hearty, P. J. (2011). Departures from eustasy in Pliocene sea-level records. Nature Geoscience, v. 4, n. 5, p. 328332.

Raymo, M. E., and Mitrovica, J. X. (2012). Collapse of polar ice sheets during the stage 11 interglacial. Nature, v. 483, n. 7390, p. 453-456.

Ritz, C., Edwards, T.L., Durand, G., Payne, A.J., Peyaud, V. and Hindmarsh, R.C. (2015).

Potential sea-level rise from Antarctic ice-sheet instability constrained by observations. Nature, v. 528, n. 7580, p. 115-118.

Robinson, R. (1976). Victoria University Antarctic Research Expedition Science and Logistics Reports 1975-76: VUWAE 20. Victoria University of Wellington.

Rodríguez-Navarro, A.B., CabraldeMelo, C., Batista, N., Morimoto, N., Alvarez-Lloret, P., Ortega-Huertas, M., Fuenzalida, V.M., Arias, J.I., Wiff, J.P. and Arias, J.L. (2006). Microstructure and crystallographic-texture of giant barnacle (Austromegabalanus psittacus) shell. Journal of Structural Biology, v. 156, n. 2, p. 355-362.

Rohling, E.J., Grant, K., Hemleben, C.H., Siddall, M., Hoogakker, B.A.A., Bolshaw, M., and Kucera, M. (2008). High rates of sea-level rise during the last interglacial period. Nature Geoscience, v. 1, n. 1, p. 38-42. 
Rosenberg, R., Nilsson, H. C., and Diaz, R. J. (2001), Response of benthic fauna and changing sediment redox profiles over a hypoxic gradient: Estuarine, Coastal and Shelf Science, v. 53, n. 3 , p. $343-350$.

Salzmann, U., Haywood, A. M., Lunt, D. J., Valdes, P. J., and Hill, D. J. (2008). A new global biome reconstruction and data-model comparison for the middle Pliocene. Global Ecology and Biogeography, v. 17, n. 3, p. 432-447.

Scherer, R.P. (1993). There is direct evidence for a late Quaternary collapse of the West Antarctic Ice Sheet. Journal of Glaciology, v. 30, n. n/a, p. 716-722

Scherer, R. P., DeConto, R. M., Pollard, D., and Alley, R. B. (2016). Windblown Pliocene diatoms and East Antarctic Ice Sheet retreat. Nature Communications, v. 7, n. 12957, doi:10.1038/ncomms12957

Seki, O., Foster, G. L., Schmidt, D. N., Mackensen, A., Kawamura, K., and Pancost, R. D. (2010). Alkenone and boron-based Pliocene pCO 2 records. Earth and Planetary Science Letters, v. 292, n. 1, p. 201-211.

Shackleton, N. J., and Kennett, J. P. (1975). Paleotemperature history of the Cenozoic and the initiation of Antarctic glaciation: oxygen and carbon isotope analyses in DSDP Sites 277, 279, and 281: Initial reports of the deep sea drilling project, v. 29, n. n/a, p. 743-755.

Siddall, M., Rohling, E.J., Almogi-Labin, A., Hemleben, C., Meischner, D., Schmelzer, I., and Smeed, D.A. (2003). Sea-level fluctuations during the last glacial cycle. Nature, v. 423, n. 6942, p. 853-858.

Sierro, F.J., Hodell, D.A., Curtis, J.H., Flores, J.A., Reguera, I., Colmenero-Hidalgo, E., Bárcena, M.A., Grimalt, J.O., Cacho, I., Frigola, J., and Canals, M. (2005). Impact of iceberg melting on Mediterranean thermohaline circulation during Heinrich events. Paleoceanography, v. 20, n. 2.

Smith, P.M. (1981). The role of the Dry Valley Drilling Project in Antarctic and international science policy. Dry valley drilling project, p. 1-5.

Southward, A.J., and Southward, E. C. (1958). On the occurrence and behaviour of two littleknown barnacles, Hexelasma hirsutum and Verruca recta, from the continental slope. Journal of the Marine Biological Association of the United Kingdom, v. 37, n. 03, p. 633-647. 
Sosdian S., Rosenthal Y. (2009). Deep-sea temperature and ice volume changes across the Pliocene-Pleistocene climate transitions: Science, v. 325, p.306310, doi:10.1126/science. 1169938

Speden, I. G. (1962). Fossiliferous Quaternary marine deposits in the McMurdo Sound region, Antarctica. New Zealand Journal of Geology and Geophysics, v. 5, n. 5, p. 746-777.

Stern, T.A., Baxter, A.K., and Barrett, P. (2005). Isostatic rebound due to glacial erosion within the Transantarctic Mountains. Geology v. 33, n. n/a, p. 221-224.

Stern, T.A., Davey, F.J., and Delisle, G. (1991). Lithospheric flexure induced by the load of the Ross Archipelago, southern Victoria Land, Antarctica. Geological evolution of Antarctica, p. 323-328.

Stirling, C.H., Esat, T.M., Lambeck, K., and McCulloch, M.T. (1998). Timing and duration of the Last Interglacial: evidence for a restricted interval of widespread coral reef growth. Earth and Planetary Science Letters, v. 160, n. 3, p. 745-762.

Stroeven, A.P., and Prentice, M. (1997). A case for Sirius Group alpine glaciation at Mount Flemming, South Victoria Land, Antarctica: A case against Pliocene East Antarctic Ice Sheet reduction. Geological Society of America Bulletin v.109, n. n/a, p. 825-840.

Strong, C. P., and Webb, P. N. (2006). Foraminiferal biostratigraphy and palaeoecology in Upper Oligocene-Lower Miocene glacial marine sequences 9, 10, and 11, CRP-2/2A drill hole, Victoria Land Basin, Antarctica: Palaeogeography, Palaeoclimatology, Palaeoecology, v. 231, n. n/a, p. 71-100.

Stuiver, M., Denton, G.H., Hughes, T.J., and Fastook, J.L. (1981). History of the marine ice sheet in West Antarctica during the last glaciation: A working hypothesis. In: Denton, G.H. and Hughes, T.J. (eds.): The Last Great Ice Sheets. John Wiley and Sons. New York. 319-436

Stuiver, M., and Polach, H.A. (1977). Discussion reporting of 14 C data. Radiocarbon, v. 19, n. 03 , p. $355-363$.

Thierstein, H. R., and Young, J. R. (eds.). (2013). Coccolithophores: from molecular processes to global impact. Springer Science \& Business Media.

Thompson, W.G., and Goldstein, S.L. (2005). Open-system coral ages reveal persistent suborbital sea-level cycles. Science, v. 308, n. 5720, p. 401-404. 
Thompson, W.G., Curran, H.A., Wilson, M.A., and White, B. (2011). Sea-level oscillations during the last interglacial highstand recorded by Bahamas corals. Nature Geoscience, v. 4, n. 10, p. 684-687.

Underwood, A.J. (1980). The effects of grazing by gastropods and physical factors on the upper limits of distribution of intertidal macroalgae. Oecologia, v. 46, n. 2, p. 201-213.

Van der Zwaan, G., Duijnstee, I., Den Dulk, M., Ernst, S., Jannink, N., and Kouwenhoven, T. (1999). Benthic foraminifers: proxies or problems?: a review of paleocological concepts: EarthScience Reviews, v. 46, no. 1, p. 213-236.

van Hengstum, P.J., Scott, D.B., and Javaux, E.J. (2009). Foraminifera in elevated Bermudian caves provide further evidence for $+21 \mathrm{~m}$ eustatic sea level during Marine Isotope Stage 11. Quaternary Science Reviews, v. 28, n. 19, p. 1850-1860.

Vaughan, D.G., Barnes, D.K., Fretwell, P.T., and Bingham, R.G. (2011). Potential seaways across west Antarctica. Geochemistry, Geophysics, Geosystems, v. 12, n. 10.

Vella, P., Clark, R. H., Prebble, W. M., and Bradley, J. (1965). Report on the Victoria University Antarctic Expedition 1964-65: VUWAE 9. Victoria University of Wellington.

Vella, P. (1969). Surficial geological sequence, Black Island and Brown Peninsula, McMurdo Sound, Antarctica. New Zealand Journal of Geology and Geophysics, v. 12, n. 4, p. 761-770.

Ward, B. L. (1983). Benthic foraminifera of McMurdo Sound. In Oliver, R., James, P., and Jago, J. (ed.) Antarctic Earth science. Cambridge University Press.

Ward, B.L., Barrett, P.J., and Vella, P. (1987). Distribution and ecology of benthic foraminifera in McMurdo Sound, Antarctica. Palaeogeography, Palaeoclimatology, Palaeoecology, v. 58, n. 3-4, p. 139-153.

Wardlaw, B. R., and Quinn, T. M. (1991). The record of Pliocene sea-level change at Enewetak Atoll: Quaternary Science Reviews, v. 10, n. 2, p. 247-258.

Webb, P. N. (1972). Paleontology of late Tertiary-Quaternary sediments, Wright Valley, Antarctica. Antarctic Journal of the United States, v. 7, n. 4, p. 96. 
Webb, P. N. (1974). Micropaleontology, paleoecology and correlation of the Pecten Gravels, Wright Valley, Antarctica, and description of Trochoelphidiella onyxi n. gen., n. sp. Journal of Foraminiferal Research, v. 4, n. 4, p. 185-199.

Webb, P. N., Harwood, D. M., McKelvey, B. C., Mercer, J. H., and Stott, L. D. (1984). Cenozoic marine sedimentation and ice-volume variation on the East Antarctic craton. Geology, v. 12, n. 5, p. 287-291.

Webb, P. N. (1990). The Cenozoic history of Antarctica and its global impact. Antarctic Science, v. 2, n. 01, p. 3-21.

Webb, P. N., and Harwood, D. M. (1991). Late Cenozoic glacial history of the Ross embayment, Antarctica. Quaternary Science Reviews, v. 10, n. 2-3, p. 215-223.

Webb, P. N., and Wrenn, J.H. (1982). Upper Cenozoic micropaleontology and biostratigraphy of eastern Taylor Valley, Antarctica C. Craddock (Ed.), Antarctic Geoscience: Symposium on Antarctic Geology and Geophysics, August 22-27, University of Wisconsin Press, Madison. p. $1117-1122$

Wellman, H. W., Wilson, A. T., Prebble, W. M., Popplewell, K. B., Henderson, R. A., Hoare, R. A., and House, D. A. (1964). Report on the Victoria University Antarctic Expedition 196364: VUWAE 8. Victoria University of Wellington.

Wellman, H. W., and Smith, I. E. (1967). Report on the Victoria University Antarctic Expedition 1966-67: VUWAE 11. Victoria University of Wellington.

Wilson, G.S. (2000). Glacial Geology and Origin of Fossiliferous-Erratic-Bearing Moraines, Southern Mcmurdo Sound, Antarctica-an Alternative Ice Sheet Hypothesis. Paleobiology and Paleoenvironments of Eocene Rocks: McMurdo Sound, East Antarctica, p. 19-37.

Winkelmann, R., Levermann, A., Ridgwell, A., and Caldeira, K. (2015). Combustion of available fossil fuel resources sufficient to eliminate the Antarctic Ice Sheet. Science advances, v. 1, n. 8, PA1500589.

Zachos, J.C., Breza, J.R., and Wise, S.W. (1992). Early Oligocene ice-sheet expansion on Antarctica: Stable isotope and sedimentological evidence from Kerguelen Plateau, southern Indian Ocean. Geology, v. 20, n. 6, p. 569-573. 
Zachos, J. C., Dickens, G. R., and Zeebe, R. E. (2008). An early Cenozoic perspective on greenhouse warming and carbon-cycle dynamics. Nature, v. 451, n. 7176, p. 279-283. 


\section{$\underline{\text { Appendix A }}$}

Appendix A contains grainsize data for each sample. Displayed in tables below are the weight percent of each grainsize distribution, clast counts, and independent results from laser partical size analysis. Results for DO1A are listed first, followed by DO3A, and BO1AB.

\begin{tabular}{|c|c|c|c|c|c|c|c|c|c|c|c|}
\hline $\begin{array}{l}\text { Diameter } \\
(\mu \mathrm{m})\end{array}$ & $\begin{array}{l}20 \\
\mathrm{~cm}\end{array}$ & $\begin{array}{l}50 \\
\mathrm{~cm}\end{array}$ & $\begin{array}{l}80 \\
\mathrm{~cm}\end{array}$ & $\begin{array}{l}110 \\
\mathrm{~cm}\end{array}$ & $\begin{array}{l}140 \\
\mathrm{~cm}\end{array}$ & $\begin{array}{l}170 \\
\mathrm{~cm}\end{array}$ & $\begin{array}{l}200 \\
\mathrm{~cm}\end{array}$ & $\begin{array}{l}230 \\
\mathrm{~cm}\end{array}$ & $\begin{array}{l}260 \\
\mathrm{~cm}\end{array}$ & $\begin{array}{l}290 \\
\mathrm{~cm}\end{array}$ & $\begin{array}{l}320 \\
\mathrm{~cm}\end{array}$ \\
\hline 0.375 & 0.00 & 0.00 & 0.00 & 0.00 & 0.00 & 0.00 & 0.00 & 0.00 & 0.00 & 0.00 & 0.00 \\
\hline 0.412 & 0.00 & 0.00 & 0.00 & 0.00 & 0.00 & 0.00 & 0.00 & 0.00 & 0.00 & 0.00 & 0.00 \\
\hline 0.452 & 0.00 & 0.00 & 0.00 & 0.00 & 0.00 & 0.00 & 0.00 & 0.00 & 0.00 & 0.00 & 0.00 \\
\hline 0.496 & 0.00 & 0.00 & 0.00 & 0.00 & 0.00 & 0.00 & 0.00 & 0.00 & 0.00 & 0.00 & 0.00 \\
\hline 0.545 & 0.00 & 0.00 & 0.00 & 0.00 & 0.00 & 0.00 & 0.00 & 0.00 & 0.00 & 0.00 & 0.00 \\
\hline 0.598 & 0.00 & 0.00 & 0.00 & 0.00 & 0.00 & 0.00 & 0.00 & 0.00 & 0.00 & 0.00 & 0.00 \\
\hline 0.657 & 0.00 & 0.00 & 0.00 & 0.00 & 0.00 & 0.00 & 0.00 & 0.00 & 0.00 & 0.00 & 0.00 \\
\hline 0.721 & 0.00 & 0.00 & 0.00 & 0.00 & 0.00 & 0.00 & 0.00 & 0.00 & 0.00 & 0.00 & 0.00 \\
\hline 0.791 & 0.00 & 0.00 & 0.00 & 0.00 & 0.00 & 0.00 & 0.00 & 0.00 & 0.00 & 0.00 & 0.00 \\
\hline 0.869 & 0.00 & 0.00 & 0.00 & 0.00 & 0.00 & 0.00 & 0.00 & 0.00 & 0.00 & 0.00 & 0.00 \\
\hline 0.953 & 0.00 & 0.00 & 0.00 & 0.00 & 0.00 & 0.00 & 0.00 & 0.00 & 0.00 & 0.00 & 0.00 \\
\hline 1.047 & 0.00 & 0.00 & 0.00 & 0.00 & 0.00 & 0.00 & 0.00 & 0.00 & 0.00 & 0.00 & 0.00 \\
\hline 1.149 & 0.00 & 0.00 & 0.00 & 0.00 & 0.00 & 0.00 & 0.00 & 0.00 & 0.00 & 0.00 & 0.00 \\
\hline 1.261 & 0.00 & 0.00 & 0.00 & 0.00 & 0.00 & 0.00 & 0.00 & 0.00 & 0.00 & 0.00 & 0.00 \\
\hline 1.385 & 0.00 & 0.00 & 0.00 & 0.00 & 0.00 & 0.00 & 0.00 & 0.00 & 0.00 & 0.00 & 0.01 \\
\hline 1.520 & 0.00 & 0.02 & 0.00 & 0.01 & 0.04 & 0.03 & 0.01 & 0.00 & 0.01 & 0.00 & 0.07 \\
\hline 1.669 & 0.01 & 0.10 & 0.02 & 0.06 & 0.19 & 0.18 & 0.08 & 0.03 & 0.06 & 0.02 & 0.20 \\
\hline 1.832 & 0.04 & 0.27 & 0.10 & 0.21 & 0.49 & 0.45 & 0.26 & 0.09 & 0.17 & 0.07 & 0.41 \\
\hline 2.010 & 0.10 & 0.52 & 0.25 & 0.45 & 0.88 & 0.79 & 0.52 & 0.18 & 0.32 & 0.15 & 0.64 \\
\hline 2.207 & 0.16 & 0.77 & 0.44 & 0.71 & 1.25 & 1.11 & 0.81 & 0.29 & 0.46 & 0.24 & 0.87 \\
\hline
\end{tabular}




\begin{tabular}{|c|c|c|c|c|c|c|c|c|c|c|c|}
\hline 2.423 & 0.22 & 1.01 & 0.61 & 0.95 & 1.58 & 1.38 & 1.07 & 0.38 & 0.57 & 0.33 & 1.08 \\
\hline 2.660 & 0.26 & 1.22 & 0.74 & 1.15 & 1.87 & 1.62 & 1.30 & 0.45 & 0.65 & 0.39 & 1.26 \\
\hline 2.920 & 0.30 & 1.39 & 0.84 & 1.30 & 2.10 & 1.80 & 1.49 & 0.50 & 0.70 & 0.43 & 1.42 \\
\hline 3.206 & 0.32 & 1.53 & 0.91 & 1.39 & 2.27 & 1.93 & 1.63 & 0.52 & 0.72 & 0.46 & 1.54 \\
\hline 3.519 & 0.34 & 1.64 & 0.95 & 1.46 & 2.38 & 2.01 & 1.74 & 0.53 & 0.73 & 0.47 & 1.63 \\
\hline 3.862 & 0.35 & 1.72 & 0.99 & 1.51 & 2.45 & 2.06 & 1.82 & 0.53 & 0.73 & 0.48 & 1.70 \\
\hline 4.241 & 0.37 & 1.81 & 1.03 & 1.58 & 2.55 & 2.13 & 1.92 & 0.55 & 0.75 & 0.51 & 1.78 \\
\hline 4.656 & 0.39 & 1.89 & 1.08 & 1.65 & 2.63 & 2.20 & 2.02 & 0.58 & 0.78 & 0.53 & 1.86 \\
\hline 5.111 & 0.42 & 1.98 & 1.13 & 1.73 & 2.72 & 2.28 & 2.13 & 0.61 & 0.82 & 0.56 & 1.95 \\
\hline 5.611 & 0.43 & 2.02 & 1.15 & 1.76 & 2.75 & 2.30 & 2.19 & 0.63 & 0.84 & 0.58 & 2.00 \\
\hline 6.158 & 0.44 & 2.04 & 1.14 & 1.77 & 2.73 & 2.31 & 2.22 & 0.64 & 0.86 & 0.59 & 2.04 \\
\hline 6.761 & 0.44 & 2.02 & 1.12 & 1.74 & 2.68 & 2.27 & 2.22 & 0.63 & 0.85 & 0.58 & 2.06 \\
\hline 7.421 & 0.45 & 2.02 & 1.09 & 1.73 & 2.65 & 2.26 & 2.24 & 0.64 & 0.86 & 0.59 & 2.10 \\
\hline 8.147 & 0.47 & 2.03 & 1.07 & 1.73 & 2.63 & 2.26 & 2.28 & 0.65 & 0.88 & 0.59 & 2.15 \\
\hline 8.944 & 0.49 & 2.04 & 1.06 & 1.74 & 2.61 & 2.26 & 2.33 & 0.67 & 0.89 & 0.61 & 2.19 \\
\hline 9.819 & 0.51 & 2.07 & 1.06 & 1.78 & 2.62 & 2.28 & 2.41 & 0.70 & 0.92 & 0.63 & 2.26 \\
\hline 10.78 & 0.54 & 2.10 & 1.05 & 1.81 & 2.62 & 2.29 & 2.48 & 0.73 & 0.95 & 0.66 & 2.31 \\
\hline 11.83 & 0.58 & 2.16 & 1.07 & 1.87 & 2.67 & 2.34 & 2.61 & 0.79 & 1.01 & 0.70 & 2.39 \\
\hline 12.99 & 0.62 & 2.21 & 1.09 & 1.93 & 2.72 & 2.38 & 2.73 & 0.84 & 1.06 & 0.74 & 2.46 \\
\hline 14.26 & 0.65 & 2.28 & 1.12 & 2.00 & 2.80 & 2.44 & 2.88 & 0.90 & 1.12 & 0.79 & 2.53 \\
\hline 15.65 & 0.66 & 2.30 & 1.12 & 2.02 & 2.81 & 2.44 & 2.94 & 0.91 & 1.13 & 0.81 & 2.54 \\
\hline 17.17 & 0.65 & 2.26 & 1.09 & 1.97 & 2.76 & 2.37 & 2.92 & 0.89 & 1.10 & 0.79 & 2.48 \\
\hline 18.86 & 0.61 & 2.15 & 1.03 & 1.87 & 2.64 & 2.23 & 2.81 & 0.84 & 1.03 & 0.75 & 2.36 \\
\hline 20.70 & 0.56 & 2.02 & 0.95 & 1.72 & 2.48 & 2.06 & 2.65 & 0.79 & 0.95 & 0.69 & 2.19 \\
\hline 22.73 & 0.54 & 1.94 & 0.90 & 1.61 & 2.37 & 1.93 & 2.56 & 0.77 & 0.91 & 0.66 & 2.07 \\
\hline 24.95 & 0.56 & 1.93 & 0.88 & 1.53 & 2.31 & 1.87 & 2.55 & 0.79 & 0.91 & 0.67 & 1.97 \\
\hline 27.38 & 0.61 & 2.02 & 0.90 & 1.51 & 2.32 & 1.88 & 2.67 & 0.86 & 0.97 & 0.73 & 1.95 \\
\hline
\end{tabular}




\begin{tabular}{|c|c|c|c|c|c|c|c|c|c|c|c|}
\hline 30.07 & 0.68 & 2.14 & 0.92 & 1.49 & 2.33 & 1.92 & 2.83 & 0.94 & 1.05 & 0.81 & 1.94 \\
\hline 33.00 & 0.74 & 2.23 & 0.93 & 1.43 & 2.28 & 1.93 & 2.93 & 1.00 & 1.11 & 0.89 & 1.92 \\
\hline 36.24 & 0.77 & 2.23 & 0.88 & 1.31 & 2.11 & 1.87 & 2.90 & 1.01 & 1.13 & 0.93 & 1.85 \\
\hline 39.77 & 0.76 & 2.13 & 0.80 & 1.14 & 1.84 & 1.72 & 2.71 & 0.97 & 1.09 & 0.93 & 1.72 \\
\hline 43.66 & 0.72 & 1.94 & 0.70 & 0.95 & 1.54 & 1.52 & 2.42 & 0.91 & 1.03 & 0.89 & 1.57 \\
\hline 47.93 & 0.67 & 1.73 & 0.61 & 0.78 & 1.26 & 1.32 & 2.10 & 0.83 & 0.95 & 0.83 & 1.43 \\
\hline 52.63 & 0.61 & 1.54 & 0.54 & 0.66 & 1.07 & 1.17 & 1.82 & 0.77 & 0.89 & 0.78 & 1.32 \\
\hline 57.77 & 0.58 & 1.40 & 0.51 & 0.60 & 0.96 & 1.09 & 1.63 & 0.74 & 0.86 & 0.75 & 1.26 \\
\hline 63.41 & 0.55 & 1.32 & 0.50 & 0.57 & 0.92 & 1.06 & 1.52 & 0.72 & 0.84 & 0.73 & 1.23 \\
\hline 69.62 & 0.53 & 1.27 & 0.49 & 0.57 & 0.91 & 1.07 & 1.47 & 0.71 & 0.83 & 0.72 & 1.22 \\
\hline 76.43 & 0.51 & 1.22 & 0.48 & 0.55 & 0.89 & 1.07 & 1.43 & 0.70 & 0.82 & 0.72 & 1.18 \\
\hline 83.90 & 0.50 & 1.16 & 0.44 & 0.52 & 0.84 & 1.06 & 1.38 & 0.67 & 0.79 & 0.72 & 1.12 \\
\hline 92.09 & 0.48 & 1.08 & 0.40 & 0.47 & 0.77 & 1.03 & 1.30 & 0.63 & 0.77 & 0.72 & 1.03 \\
\hline 101.1 & 0.47 & 1.00 & 0.35 & 0.41 & 0.69 & 0.99 & 1.22 & 0.61 & 0.75 & 0.71 & 0.93 \\
\hline 111.0 & 0.47 & 0.93 & 0.32 & 0.37 & 0.63 & 0.96 & 1.14 & 0.60 & 0.74 & 0.72 & 0.85 \\
\hline 121.8 & 0.49 & 0.89 & 0.32 & 0.35 & 0.61 & 0.96 & 1.11 & 0.62 & 0.77 & 0.73 & 0.79 \\
\hline 133.7 & 0.52 & 0.89 & 0.33 & 0.35 & 0.64 & 0.98 & 1.12 & 0.67 & 0.82 & 0.76 & 0.77 \\
\hline 146.8 & 0.57 & 0.94 & 0.37 & 0.38 & 0.70 & 1.02 & 1.16 & 0.75 & 0.90 & 0.81 & 0.79 \\
\hline 161.2 & 0.64 & 1.01 & 0.42 & 0.43 & 0.76 & 1.04 & 1.20 & 0.85 & 1.00 & 0.89 & 0.83 \\
\hline 176.8 & 0.71 & 1.09 & 0.46 & 0.48 & 0.80 & 1.01 & 1.19 & 0.95 & 1.11 & 0.99 & 0.88 \\
\hline 194.2 & 0.79 & 1.14 & 0.49 & 0.50 & 0.78 & 0.89 & 1.08 & 1.03 & 1.19 & 1.08 & 0.88 \\
\hline 213.2 & 0.85 & 1.11 & 0.50 & 0.49 & 0.69 & 0.70 & 0.88 & 1.10 & 1.21 & 1.14 & 0.83 \\
\hline 234.1 & 0.88 & 1.02 & 0.49 & 0.44 & 0.53 & 0.43 & 0.59 & 1.13 & 1.16 & 1.15 & 0.71 \\
\hline 256.8 & 0.91 & 0.88 & 0.47 & 0.36 & 0.35 & 0.19 & 0.29 & 1.16 & 1.08 & 1.11 & 0.55 \\
\hline 282.1 & 0.95 & 0.78 & 0.46 & 0.29 & 0.20 & 0.04 & 0.09 & 1.20 & 0.99 & 1.06 & 0.42 \\
\hline 309.6 & 1.04 & 0.76 & 0.49 & 0.26 & 0.13 & 0.01 & 0.01 & 1.30 & 0.98 & 1.04 & 0.37 \\
\hline 339.8 & 1.20 & 0.85 & 0.58 & 0.30 & 0.13 & 0.01 & 0.00 & 1.48 & 1.08 & 1.12 & 0.42 \\
\hline 373.1 & 1.45 & 1.05 & 0.73 & 0.41 & 0.19 & 0.08 & 0.00 & 1.74 & 1.31 & 1.31 & 0.58 \\
\hline
\end{tabular}




\begin{tabular}{|l|l|l|l|l|l|l|l|l|l|l|l|}
\hline 409.6 & 1.79 & 1.30 & 0.94 & 0.62 & 0.30 & 0.26 & 0.00 & 2.08 & 1.64 & 1.63 & 0.81 \\
\hline 449.7 & 2.22 & 1.50 & 1.20 & 0.90 & 0.42 & 0.48 & 0.00 & 2.47 & 2.04 & 2.04 & 1.04 \\
\hline 493.6 & 2.71 & 1.56 & 1.51 & 1.24 & 0.49 & 0.66 & 0.00 & 2.88 & 2.42 & 2.46 & 1.19 \\
\hline 541.9 & 3.26 & 1.45 & 1.87 & 1.61 & 0.52 & 0.77 & 0.00 & 3.29 & 2.75 & 2.85 & 1.22 \\
\hline 594.9 & 3.83 & 1.19 & 2.30 & 2.00 & 0.52 & 0.84 & 0.00 & 3.70 & 3.02 & 3.16 & 1.15 \\
\hline 653.0 & 4.41 & 0.90 & 2.81 & 2.40 & 0.51 & 0.93 & 0.00 & 4.09 & 3.27 & 3.39 & 1.05 \\
\hline 716.9 & 4.94 & 0.66 & 3.38 & 2.81 & 0.49 & 1.08 & 0.00 & 4.45 & 3.51 & 3.55 & 1.00 \\
\hline 786.9 & 5.34 & 0.51 & 3.97 & 3.21 & 0.38 & 1.32 & 0.00 & 4.74 & 3.76 & 3.67 & 1.05 \\
\hline 863.9 & 5.56 & 0.45 & 4.49 & 3.55 & 0.21 & 1.57 & 0.00 & 4.88 & 3.99 & 3.80 & 1.17 \\
\hline 948.2 & 5.54 & 0.42 & 4.88 & 3.78 & 0.05 & 1.68 & 0.00 & 4.80 & 4.12 & 3.95 & 1.32 \\
\hline 1041 & 5.29 & 0.39 & 5.07 & 3.85 & 0.01 & 1.52 & 0.00 & 4.45 & 4.08 & 4.11 & 1.36 \\
\hline 1143 & 4.89 & 0.28 & 5.07 & 3.71 & 0.00 & 1.02 & 0.00 & 3.88 & 3.83 & 4.29 & 1.06 \\
\hline 1255 & 4.41 & 0.14 & 4.85 & 3.35 & 0.00 & 0.46 & 0.00 & 3.16 & 3.34 & 4.37 & 0.56 \\
\hline 1377 & 3.90 & 0.03 & 4.46 & 2.36 & 0.00 & 0.10 & 0.00 & 2.41 & 2.64 & 4.30 & 0.14 \\
\hline 1512 & 3.35 & 0.00 & 3.89 & 1.17 & 0.00 & 0.01 & 0.00 & 1.73 & 1.81 & 3.95 & 0.01 \\
\hline 1660 & 2.92 & 0.00 & 3.40 & 0.27 & 0.00 & 0.00 & 0.00 & 1.28 & 1.19 & 3.56 & 0.00 \\
\hline 1822 & 2.53 & 0.00 & 2.93 & 0.03 & 0.00 & 0.00 & 0.00 & 0.98 & 0.60 & 3.07 & 0.00 \\
\hline 196 & & & & & &
\end{tabular}

\begin{tabular}{|c|c|c|c|c|c|c|c|c|c|c|c|}
\hline $\begin{array}{l}\text { Diameter } \\
(\mu \mathrm{m})\end{array}$ & $\begin{array}{l}350 \\
\mathrm{~cm}\end{array}$ & $\begin{array}{l}380 \\
\mathrm{~cm}\end{array}$ & $\begin{array}{l}410 \\
\mathrm{~cm}\end{array}$ & $\begin{array}{l}440 \\
\mathrm{~cm}\end{array}$ & $\begin{array}{l}470 \\
\mathrm{~cm}\end{array}$ & $\begin{array}{l}500 \\
\mathrm{~cm}\end{array}$ & $\begin{array}{l}530 \\
\mathrm{~cm}\end{array}$ & $\begin{array}{l}560 \\
\mathrm{~cm}\end{array}$ & $\begin{array}{l}590 \\
\mathrm{~cm}\end{array}$ & $\begin{array}{l}620 \\
\mathrm{~cm}\end{array}$ & $\begin{array}{l}650 \\
\mathrm{~cm}\end{array}$ \\
\hline 0.375 & 0.00 & 0.00 & 0.00 & 0.00 & 0.00 & 0.00 & 0.00 & 0.00 & 0.00 & 0.00 & 0.00 \\
\hline 0.412 & 0.00 & 0.00 & 0.00 & 0.00 & 0.00 & 0.00 & 0.00 & 0.00 & 0.00 & 0.00 & 0.00 \\
\hline 0.452 & 0.00 & 0.00 & 0.00 & 0.00 & 0.00 & 0.00 & 0.00 & 0.00 & 0.00 & 0.00 & 0.00 \\
\hline 0.496 & 0.00 & 0.00 & 0.00 & 0.00 & 0.00 & 0.00 & 0.00 & 0.00 & 0.00 & 0.00 & 0.00 \\
\hline 0.545 & 0.00 & 0.00 & 0.00 & 0.00 & 0.00 & 0.00 & 0.00 & 0.00 & 0.00 & 0.00 & 0.00 \\
\hline 0.598 & 0.00 & 0.00 & 0.00 & 0.00 & 0.00 & 0.00 & 0.00 & 0.00 & 0.00 & 0.00 & 0.00 \\
\hline 0.657 & 0.00 & 0.00 & 0.00 & 0.00 & 0.00 & 0.00 & 0.00 & 0.00 & 0.00 & 0.00 & 0.00 \\
\hline 0.721 & 0.00 & 0.00 & 0.00 & 0.00 & 0.00 & 0.00 & 0.00 & 0.00 & 0.00 & 0.00 & 0.00 \\
\hline
\end{tabular}




\begin{tabular}{|c|c|c|c|c|c|c|c|c|c|c|c|}
\hline 0.791 & 0.00 & 0.00 & 0.00 & 0.00 & 0.00 & 0.00 & 0.00 & 0.00 & 0.00 & 0.00 & 0.00 \\
\hline 0.869 & 0.00 & 0.00 & 0.00 & 0.00 & 0.00 & 0.00 & 0.00 & 0.00 & 0.00 & 0.00 & 0.00 \\
\hline 0.953 & 0.00 & 0.00 & 0.00 & 0.00 & 0.00 & 0.00 & 0.00 & 0.00 & 0.00 & 0.00 & 0.00 \\
\hline 1.047 & 0.00 & 0.00 & 0.00 & 0.00 & 0.00 & 0.00 & 0.00 & 0.00 & 0.00 & 0.00 & 0.00 \\
\hline 1.149 & 0.00 & 0.00 & 0.00 & 0.00 & 0.00 & 0.00 & 0.00 & 0.00 & 0.00 & 0.00 & 0.00 \\
\hline 1.261 & 0.00 & 0.00 & 0.00 & 0.00 & 0.00 & 0.00 & 0.00 & 0.00 & 0.00 & 0.00 & 0.00 \\
\hline 1.385 & 0.00 & 0.00 & 0.00 & 0.00 & 0.02 & 0.00 & 0.01 & 0.01 & 0.01 & 0.03 & 0.03 \\
\hline 1.520 & 0.01 & 0.01 & 0.02 & 0.03 & 0.10 & 0.03 & 0.05 & 0.08 & 0.08 & 0.14 & 0.14 \\
\hline 1.669 & 0.06 & 0.08 & 0.09 & 0.12 & 0.26 & 0.15 & 0.19 & 0.26 & 0.28 & 0.37 & 0.37 \\
\hline 1.832 & 0.19 & 0.21 & 0.23 & 0.29 & 0.50 & 0.39 & 0.42 & 0.53 & 0.63 & 0.69 & 0.69 \\
\hline 2.010 & 0.40 & 0.40 & 0.42 & 0.50 & 0.75 & 0.70 & 0.69 & 0.83 & 1.04 & 1.01 & 1.01 \\
\hline 2.207 & 0.65 & 0.59 & 0.59 & 0.69 & 0.97 & 0.97 & 0.94 & 1.11 & 1.42 & 1.32 & 1.30 \\
\hline 2.423 & 0.87 & 0.75 & 0.74 & 0.83 & 1.16 & 1.20 & 1.14 & 1.35 & 1.73 & 1.57 & 1.55 \\
\hline 2.660 & 1.08 & 0.89 & 0.87 & 0.94 & 1.32 & 1.38 & 1.30 & 1.54 & 1.98 & 1.77 & 1.75 \\
\hline 2.920 & 1.27 & 1.00 & 0.97 & 1.00 & 1.42 & 1.51 & 1.41 & 1.68 & 2.15 & 1.92 & 1.89 \\
\hline 3.206 & 1.42 & 1.08 & 1.04 & 1.02 & 1.48 & 1.59 & 1.47 & 1.76 & 2.24 & 2.00 & 1.97 \\
\hline 3.519 & 1.55 & 1.14 & 1.09 & 1.02 & 1.50 & 1.64 & 1.50 & 1.80 & 2.28 & 2.04 & 2.01 \\
\hline 3.862 & 1.66 & 1.18 & 1.12 & 1.01 & 1.50 & 1.66 & 1.52 & 1.81 & 2.30 & 2.07 & 2.03 \\
\hline 4.241 & 1.78 & 1.24 & 1.16 & 1.02 & 1.53 & 1.71 & 1.56 & 1.86 & 2.35 & 2.12 & 2.08 \\
\hline 4.656 & 1.89 & 1.30 & 1.20 & 1.04 & 1.55 & 1.76 & 1.61 & 1.91 & 2.42 & 2.17 & 2.12 \\
\hline 5.111 & 2.02 & 1.37 & 1.25 & 1.07 & 1.58 & 1.84 & 1.67 & 1.98 & 2.51 & 2.24 & 2.18 \\
\hline 5.611 & 2.09 & 1.40 & 1.27 & 1.08 & 1.58 & 1.87 & 1.71 & 2.00 & 2.54 & 2.26 & 2.20 \\
\hline 6.158 & 2.16 & 1.43 & 1.27 & 1.08 & 1.57 & 1.88 & 1.73 & 2.01 & 2.56 & 2.28 & 2.22 \\
\hline 6.761 & 2.19 & 1.43 & 1.26 & 1.06 & 1.54 & 1.87 & 1.73 & 2.00 & 2.54 & 2.27 & 2.21 \\
\hline 7.421 & 2.25 & 1.44 & 1.26 & 1.05 & 1.54 & 1.88 & 1.75 & 2.02 & 2.55 & 2.28 & 2.23 \\
\hline 8.147 & 2.32 & 1.47 & 1.26 & 1.06 & 1.54 & 1.91 & 1.79 & 2.05 & 2.58 & 2.31 & 2.27 \\
\hline 8.944 & 2.42 & 1.50 & 1.28 & 1.06 & 1.54 & 1.95 & 1.83 & 2.10 & 2.62 & 2.34 & 2.31 \\
\hline
\end{tabular}




\begin{tabular}{|c|c|c|c|c|c|c|c|c|c|c|c|}
\hline 9.819 & 2.54 & 1.55 & 1.31 & 1.08 & 1.57 & 2.01 & 1.90 & 2.17 & 2.69 & 2.38 & 2.38 \\
\hline 10.78 & 2.66 & 1.60 & 1.33 & 1.10 & 1.58 & 2.05 & 1.95 & 2.23 & 2.73 & 2.41 & 2.44 \\
\hline 11.83 & 2.84 & 1.67 & 1.39 & 1.14 & 1.64 & 2.14 & 2.04 & 2.34 & 2.83 & 2.47 & 2.54 \\
\hline 12.99 & 3.01 & 1.74 & 1.45 & 1.18 & 1.68 & 2.21 & 2.12 & 2.43 & 2.89 & 2.51 & 2.62 \\
\hline 14.26 & 3.22 & 1.81 & 1.51 & 1.23 & 1.73 & 2.29 & 2.20 & 2.54 & 2.96 & 2.57 & 2.72 \\
\hline 15.65 & 3.35 & 1.83 & 1.54 & 1.23 & 1.73 & 2.29 & 2.20 & 2.56 & 2.94 & 2.55 & 2.74 \\
\hline 17.17 & 3.40 & 1.79 & 1.52 & 1.17 & 1.68 & 2.21 & 2.14 & 2.51 & 2.83 & 2.45 & 2.67 \\
\hline 18.86 & 3.36 & 1.69 & 1.46 & 1.08 & 1.57 & 2.07 & 2.01 & 2.37 & 2.64 & 2.28 & 2.53 \\
\hline 20.70 & 3.28 & 1.58 & 1.38 & 0.99 & 1.46 & 1.88 & 1.86 & 2.20 & 2.42 & 2.07 & 2.36 \\
\hline 22.73 & 3.27 & 1.52 & 1.33 & 0.94 & 1.39 & 1.75 & 1.76 & 2.08 & 2.25 & 1.90 & 2.23 \\
\hline 24.95 & 3.33 & 1.53 & 1.34 & 0.96 & 1.39 & 1.67 & 1.72 & 2.03 & 2.14 & 1.78 & 2.16 \\
\hline 27.38 & 3.49 & 1.62 & 1.41 & 1.05 & 1.46 & 1.67 & 1.75 & 2.07 & 2.11 & 1.74 & 2.18 \\
\hline 30.07 & 3.66 & 1.75 & 1.49 & 1.16 & 1.56 & 1.69 & 1.79 & 2.13 & 2.08 & 1.73 & 2.19 \\
\hline 33.00 & 3.74 & 1.86 & 1.56 & 1.26 & 1.63 & 1.70 & 1.79 & 2.14 & 2.00 & 1.71 & 2.16 \\
\hline 36.24 & 3.64 & 1.90 & 1.57 & 1.29 & 1.62 & 1.65 & 1.71 & 2.07 & 1.83 & 1.63 & 2.03 \\
\hline 39.77 & 3.36 & 1.86 & 1.52 & 1.26 & 1.54 & 1.53 & 1.55 & 1.90 & 1.60 & 1.48 & 1.80 \\
\hline 43.66 & 2.94 & 1.75 & 1.42 & 1.19 & 1.41 & 1.39 & 1.36 & 1.69 & 1.35 & 1.30 & 1.53 \\
\hline 47.93 & 2.48 & 1.63 & 1.32 & 1.11 & 1.27 & 1.25 & 1.17 & 1.47 & 1.13 & 1.12 & 1.27 \\
\hline 52.63 & 2.06 & 1.52 & 1.23 & 1.04 & 1.17 & 1.15 & 1.03 & 1.31 & 0.97 & 0.97 & 1.08 \\
\hline 57.77 & 1.73 & 1.46 & 1.18 & 1.01 & 1.12 & 1.09 & 0.94 & 1.19 & 0.89 & 0.87 & 0.96 \\
\hline 63.41 & 1.49 & 1.43 & 1.15 & 1.01 & 1.10 & 1.06 & 0.89 & 1.12 & 0.86 & 0.81 & 0.89 \\
\hline 69.62 & 1.31 & 1.42 & 1.14 & 1.00 & 1.09 & 1.04 & 0.85 & 1.06 & 0.84 & 0.76 & 0.85 \\
\hline 76.43 & 1.15 & 1.41 & 1.13 & 0.99 & 1.07 & 0.99 & 0.81 & 0.99 & 0.81 & 0.72 & 0.81 \\
\hline 83.90 & 0.99 & 1.39 & 1.10 & 0.95 & 1.03 & 0.92 & 0.74 & 0.89 & 0.75 & 0.66 & 0.75 \\
\hline 92.09 & 0.82 & 1.36 & 1.07 & 0.89 & 0.96 & 0.85 & 0.67 & 0.79 & 0.66 & 0.60 & 0.68 \\
\hline 101.1 & 0.68 & 1.32 & 1.04 & 0.83 & 0.90 & 0.78 & 0.62 & 0.69 & 0.58 & 0.54 & 0.61 \\
\hline 111.0 & 0.58 & 1.30 & 1.03 & 0.79 & 0.86 & 0.74 & 0.58 & 0.63 & 0.53 & 0.49 & 0.57 \\
\hline 121.8 & 0.55 & 1.31 & 1.05 & 0.77 & 0.85 & 0.74 & 0.59 & 0.61 & 0.51 & 0.47 & 0.55 \\
\hline
\end{tabular}




\begin{tabular}{|c|c|c|c|c|c|c|c|c|c|c|c|}
\hline 133.7 & 0.55 & 1.35 & 1.11 & 0.79 & 0.89 & 0.79 & 0.63 & 0.62 & 0.52 & 0.46 & 0.57 \\
\hline 146.8 & 0.58 & 1.43 & 1.20 & 0.84 & 0.96 & 0.86 & 0.69 & 0.66 & 0.57 & 0.49 & 0.61 \\
\hline 161.2 & 0.57 & 1.52 & 1.31 & 0.92 & 1.05 & 0.94 & 0.77 & 0.69 & 0.63 & 0.54 & 0.67 \\
\hline 176.8 & 0.49 & 1.60 & 1.42 & 1.00 & 1.14 & 1.02 & 0.84 & 0.71 & 0.68 & 0.59 & 0.73 \\
\hline 194.2 & 0.35 & 1.63 & 1.49 & 1.06 & 1.21 & 1.06 & 0.88 & 0.69 & 0.69 & 0.61 & 0.76 \\
\hline 213.2 & 0.18 & 1.59 & 1.49 & 1.05 & 1.21 & 1.04 & 0.86 & 0.61 & 0.63 & 0.59 & 0.73 \\
\hline 234.1 & 0.06 & 1.45 & 1.42 & 0.98 & 1.16 & 0.98 & 0.78 & 0.47 & 0.51 & 0.51 & 0.64 \\
\hline 256.8 & 0.01 & 1.27 & 1.31 & 0.86 & 1.07 & 0.89 & 0.67 & 0.31 & 0.37 & 0.40 & 0.50 \\
\hline 282.1 & 0.00 & 1.10 & 1.24 & 0.75 & 1.00 & 0.84 & 0.57 & 0.21 & 0.27 & 0.31 & 0.38 \\
\hline 309.6 & 0.00 & 1.02 & 1.25 & 0.72 & 1.00 & 0.85 & 0.55 & 0.18 & 0.25 & 0.30 & 0.32 \\
\hline 339.8 & 0.00 & 1.06 & 1.37 & 0.82 & 1.10 & 0.96 & 0.64 & 0.24 & 0.31 & 0.38 & 0.34 \\
\hline 373.1 & 0.00 & 1.20 & 1.61 & 1.05 & 1.30 & 1.15 & 0.83 & 0.40 & 0.44 & 0.56 & 0.45 \\
\hline 409.6 & 0.00 & 1.41 & 1.89 & 1.40 & 1.55 & 1.38 & 1.11 & 0.64 & 0.61 & 0.81 & 0.63 \\
\hline 449.7 & 0.00 & 1.57 & 2.14 & 1.80 & 1.77 & 1.58 & 1.40 & 0.86 & 0.75 & 1.04 & 0.80 \\
\hline 493.6 & 0.00 & 1.62 & 2.27 & 2.16 & 1.88 & 1.68 & 1.61 & 0.98 & 0.83 & 1.16 & 0.92 \\
\hline 541.9 & 0.00 & 1.53 & 2.28 & 2.44 & 1.85 & 1.65 & 1.68 & 1.00 & 0.85 & 1.16 & 0.95 \\
\hline 594.9 & 0.00 & 1.34 & 2.21 & 2.66 & 1.73 & 1.52 & 1.66 & 0.95 & 0.83 & 1.07 & 0.94 \\
\hline 653.0 & 0.00 & 1.17 & 2.11 & 2.86 & 1.61 & 1.39 & 1.63 & 0.91 & 0.81 & 0.98 & 0.94 \\
\hline 716.9 & 0.00 & 1.08 & 2.06 & 3.11 & 1.59 & 1.31 & 1.67 & 0.96 & 0.79 & 0.98 & 1.00 \\
\hline 786.9 & 0.00 & 1.11 & 2.07 & 3.43 & 1.74 & 1.32 & 1.89 & 1.14 & 0.61 & 1.14 & 1.11 \\
\hline 863.9 & 0.00 & 1.24 & 2.10 & 3.78 & 2.03 & 1.40 & 2.25 & 1.44 & 0.34 & 1.42 & 1.24 \\
\hline 948.2 & 0.00 & 1.39 & 2.09 & 4.04 & 2.36 & 1.47 & 2.68 & 1.77 & 0.09 & 1.75 & 1.06 \\
\hline 1041 & 0.00 & 1.48 & 2.01 & 4.10 & 2.49 & 1.43 & 2.92 & 1.95 & 0.01 & 1.94 & 0.62 \\
\hline 1143 & 0.00 & 1.46 & 1.83 & 3.86 & 1.97 & 1.07 & 2.36 & 1.58 & 0.00 & 1.58 & 0.16 \\
\hline 1255 & 0.00 & 1.32 & 1.58 & 3.32 & 1.06 & 0.55 & 1.30 & 0.87 & 0.00 & 0.86 & 0.02 \\
\hline 1377 & 0.00 & 0.93 & 1.09 & 2.22 & 0.26 & 0.13 & 0.32 & 0.21 & 0.00 & 0.21 & 0.00 \\
\hline 1512 & 0.00 & 0.46 & 0.54 & 1.04 & 0.03 & 0.01 & 0.03 & 0.02 & 0.00 & 0.02 & 0.00 \\
\hline 1660 & 0.00 & 0.11 & 0.12 & 0.23 & 0.00 & 0.00 & 0.00 & 0.00 & 0.00 & 0.00 & 0.00 \\
\hline
\end{tabular}




\begin{tabular}{|l|l|l|l|l|l|l|l|l|l|l|l|}
\hline 1822 & 0.00 & 0.01 & 0.01 & 0.02 & 0.00 & 0.00 & 0.00 & 0.00 & 0.00 & 0.00 & 0.00 \\
\hline
\end{tabular}

\begin{tabular}{|c|c|c|c|c|c|c|c|c|c|}
\hline $\begin{array}{l}\text { D01A Sample } \\
\text { Position }\end{array}$ & $\begin{array}{l}<0.5 \\
\mathrm{~mm} \\
(\mathrm{~g})\end{array}$ & $\begin{array}{l}0.5-2 \\
\mathrm{~mm}(\mathrm{~g})\end{array}$ & $\begin{array}{l}>2 \\
\mathrm{~mm} \\
(\mathrm{~g})\end{array}$ & Clast \# & $\begin{array}{l}\text { wt } \% \\
\text { fine }\end{array}$ & $\begin{array}{l}\text { wt } \% \\
\text { coarse }\end{array}$ & $\begin{array}{l}\text { wt \% > } \\
2 \mathrm{~mm}\end{array}$ & $\begin{array}{l}\text { LPS } \\
\text { mean } \\
(\mu \mathrm{m})\end{array}$ & $\begin{array}{l}\text { LPS } \% \\
\text { mud }\end{array}$ \\
\hline $20 \mathrm{~cm}$ & 16.88 & 60.68 & 207.51 & 89 & 5.92 & 21.29 & 72.79 & 709.8 & 18.5 \\
\hline $50 \mathrm{~cm}$ & 72.51 & 12.13 & 2.37 & 4 & 83.34 & 13.94 & 2.72 & 118.8 & 68.6 \\
\hline $80 \mathrm{~cm}$ & 18.78 & 26.27 & 211.76 & 82 & 7.31 & 10.23 & 82.46 & 653.3 & 33.8 \\
\hline $110 \mathrm{~cm}$ & 26.16 & 15.37 & 184.98 & 76 & 11.55 & 6.79 & 81.67 & 380.1 & 54.5 \\
\hline $140 \mathrm{~cm}$ & 38.25 & 16.76 & 12.87 & 41 & 56.35 & 24.69 & 18.96 & 55.93 & 83.8 \\
\hline $170 \mathrm{~cm}$ & 48.27 & 7.59 & 23.41 & 38 & 60.89 & 9.57 & 29.53 & 140.5 & 72.5 \\
\hline $200 \mathrm{~cm}$ & 32.04 & 29 & 13.39 & 27 & 43.05 & 38.96 & 17.99 & 39.78 & 81.6 \\
\hline $230 \mathrm{~cm}$ & 47.69 & 49.82 & 17 & 22 & 41.65 & 43.51 & 14.85 & 555.2 & 26 \\
\hline $260 \mathrm{~cm}$ & 49.73 & 62.99 & 32.58 & 45 & 34.23 & 43.35 & 22.42 & 498.1 & 32.7 \\
\hline $290 \mathrm{~cm}$ & 22.27 & 27.8 & 22.73 & 56 & 30.59 & 38.19 & 31.22 & 660 & 23.5 \\
\hline $320 \mathrm{~cm}$ & 26.06 & 33.88 & 241.47 & 79 & 8.65 & 11.24 & 80.11 & 150.8 & 69.3 \\
\hline $350 \mathrm{~cm}$ & 80.36 & 2.94 & 1.08 & 2 & 95.24 & 3.48 & 1.28 & 30.03 & 89.4 \\
\hline $380 \mathrm{~cm}$ & 24.11 & 30.21 & 218.32 & 68 & 8.84 & 11.08 & 80.08 & 222.4 & 53.4 \\
\hline $410 \mathrm{~cm}$ & 17.3 & 26.82 & 178.61 & 71 & 7.77 & 12.04 & 80.19 & 292.3 & 46.5 \\
\hline $440 \mathrm{~cm}$ & 19.6 & 18.55 & 182.2 & 84 & 8.89 & 8.42 & 82.69 & 429.7 & 39.3 \\
\hline $470 \mathrm{~cm}$ & 14.61 & 15.03 & 167.71 & 81 & 7.40 & 7.62 & 84.98 & 243.3 & 55 \\
\hline $500 \mathrm{~cm}$ & 13.98 & 13.98 & 117.95 & 73 & 9.58 & 9.58 & 80.84 & 181.6 & 63.4 \\
\hline $530 \mathrm{~cm}$ & 28.25 & 21.19 & 198.52 & 65 & 11.39 & 8.55 & 80.06 & 245.1 & 60.9 \\
\hline $560 \mathrm{~cm}$ & 29.55 & 18.35 & 34.39 & 59 & 35.91 & 22.30 & 41.79 & 163.5 & 71.9 \\
\hline $590 \mathrm{~cm}$ & 17.63 & 15.48 & 11.3 & 42 & 39.70 & 34.86 & 25.44 & 71.86 & 82 \\
\hline $620 \mathrm{~cm}$ & 19.77 & 20.14 & 10.66 & 36 & 39.09 & 39.83 & 21.08 & 165.5 & 72.9 \\
\hline $650 \mathrm{~cm}$ & 17.72 & 18.81 & 14.99 & 29 & 34.39 & 36.51 & 29.10 & 109.4 & 77 \\
\hline
\end{tabular}




\begin{tabular}{|c|c|c|c|c|c|c|c|c|c|c|c|c|c|c|c|c|c|c|c|}
\hline $\begin{array}{l}\text { Diameter } \\
(\mu \mathrm{m})\end{array}$ & $\begin{array}{l}30 \\
\mathrm{~cm}\end{array}$ & $\begin{array}{l}60 \\
\mathrm{~cm}\end{array}$ & $\begin{array}{l}90 \\
\mathrm{~cm}\end{array}$ & $\begin{array}{l}120 \\
\mathrm{~cm}\end{array}$ & $\begin{array}{l}150 \\
\mathrm{~cm}\end{array}$ & $\begin{array}{l}180 \\
\mathrm{~cm}\end{array}$ & $\begin{array}{l}210 \\
\mathrm{~cm}\end{array}$ & $\begin{array}{l}240 \\
\mathrm{~cm}\end{array}$ & $\begin{array}{l}270 \\
\mathrm{~cm}\end{array}$ & $\begin{array}{l}300 \\
\mathrm{~cm}\end{array}$ & $\begin{array}{l}330 \\
\mathrm{~cm}\end{array}$ & $\begin{array}{l}360 \\
\mathrm{~cm}\end{array}$ & $\begin{array}{l}390 \\
\mathrm{~cm}\end{array}$ & $\begin{array}{l}420 \\
\mathrm{~cm}\end{array}$ & $\begin{array}{l}450 \\
\mathrm{~cm}\end{array}$ & $\begin{array}{l}480 \\
\mathrm{~cm}\end{array}$ & $\begin{array}{l}510 \\
\mathrm{~cm}\end{array}$ & $\begin{array}{l}540 \\
\mathrm{~cm}\end{array}$ & $\begin{array}{l}570 \\
\mathrm{~cm}\end{array}$ \\
\hline 0.375 & 0.00 & 0.00 & 0.00 & 0.00 & 0.00 & 0.00 & 0.00 & 0.00 & 0.00 & 0.00 & 0.00 & 0.00 & 0.00 & 0.00 & 0.00 & 0.00 & 0.00 & 0.00 & 0.00 \\
\hline 0.412 & 0.00 & 0.00 & 0.00 & 0.00 & 0.00 & 0.00 & 0.00 & 0.00 & 0.00 & 0.00 & 0.00 & 0.00 & 0.00 & 0.00 & 0.00 & 0.00 & 0.00 & 0.00 & 0.00 \\
\hline 0.452 & 0.00 & 0.00 & 0.00 & 0.00 & 0.00 & 0.00 & 0.00 & 0.00 & 0.00 & 0.00 & 0.00 & 0.00 & 0.00 & 0.00 & 0.00 & 0.00 & 0.00 & 0.00 & 0.00 \\
\hline 0.496 & 0.00 & 0.00 & 0.00 & 0.00 & 0.00 & 0.00 & 0.00 & 0.00 & 0.00 & 0.00 & 0.00 & 0.00 & 0.00 & 0.00 & 0.00 & 0.00 & 0.00 & 0.00 & 0.00 \\
\hline 0.545 & 0.00 & 0.00 & 0.00 & 0.00 & 0.00 & 0.00 & 0.00 & 0.00 & 0.00 & 0.00 & 0.00 & 0.00 & 0.00 & 0.00 & 0.00 & 0.00 & 0.00 & 0.00 & 0.00 \\
\hline 0.598 & 0.00 & 0.00 & 0.00 & 0.00 & 0.00 & 0.00 & 0.00 & 0.00 & 0.00 & 0.00 & 0.00 & 0.00 & 0.00 & 0.00 & 0.00 & 0.00 & 0.00 & 0.00 & 0.00 \\
\hline 0.657 & 0.00 & 0.00 & 0.00 & 0.00 & 0.00 & 0.00 & 0.00 & 0.00 & 0.00 & 0.00 & 0.00 & 0.00 & 0.00 & 0.00 & 0.00 & 0.00 & 0.00 & 0.00 & 0.00 \\
\hline 0.721 & 0.00 & 0.00 & 0.00 & 0.00 & 0.00 & 0.00 & 0.00 & 0.00 & 0.00 & 0.00 & 0.00 & 0.00 & 0.00 & 0.00 & 0.00 & 0.00 & 0.00 & 0.00 & 0.00 \\
\hline 0.791 & 0.00 & 0.00 & 0.00 & 0.00 & 0.00 & 0.00 & 0.00 & 0.00 & 0.00 & 0.00 & 0.00 & 0.00 & 0.00 & 0.00 & 0.00 & 0.00 & 0.00 & 0.00 & 0.00 \\
\hline 0.869 & 0.00 & 0.00 & 0.00 & 0.00 & 0.00 & 0.00 & 0.00 & 0.00 & 0.00 & 0.00 & 0.00 & 0.00 & 0.00 & 0.00 & 0.00 & 0.00 & 0.00 & 0.00 & 0.00 \\
\hline 0.953 & 0.00 & 0.00 & 0.00 & 0.00 & 0.00 & 0.00 & 0.00 & 0.00 & 0.00 & 0.00 & 0.00 & 0.00 & 0.00 & 0.00 & 0.00 & 0.00 & 0.00 & 0.00 & 0.00 \\
\hline 1.047 & 0.00 & 0.00 & 0.00 & 0.00 & 0.00 & 0.00 & 0.00 & 0.00 & 0.00 & 0.00 & 0.00 & 0.00 & 0.00 & 0.00 & 0.00 & 0.00 & 0.00 & 0.00 & 0.00 \\
\hline 1.149 & 0.00 & 0.00 & 0.00 & 0.00 & 0.00 & 0.00 & 0.00 & 0.00 & 0.00 & 0.00 & 0.00 & 0.00 & 0.00 & 0.00 & 0.00 & 0.00 & 0.00 & 0.00 & 0.00 \\
\hline 1.261 & 0.00 & 0.00 & 0.00 & 0.00 & 0.00 & 0.00 & 0.00 & 0.00 & 0.00 & 0.00 & 0.00 & 0.00 & 0.00 & 0.00 & 0.00 & 0.00 & 0.00 & 0.00 & 0.00 \\
\hline 1.385 & 0.02 & 0.00 & 0.00 & 0.00 & 0.00 & 0.00 & 0.00 & 0.00 & 0.00 & 0.00 & 0.01 & 0.00 & 0.01 & 0.00 & 0.00 & 0.00 & 0.00 & 0.00 & 0.00 \\
\hline 1.520 & 0.07 & 0.01 & 0.03 & 0.03 & 0.02 & 0.03 & 0.03 & 0.01 & 0.01 & 0.01 & 0.05 & 0.03 & 0.06 & 0.01 & 0.01 & 0.01 & 0.01 & 0.01 & 0.01 \\
\hline 1.669 & 0.14 & 0.06 & 0.11 & 0.14 & 0.09 & 0.13 & 0.09 & 0.07 & 0.04 & 0.07 & 0.16 & 0.16 & 0.22 & 0.06 & 0.04 & 0.05 & 0.04 & 0.07 & 0.07 \\
\hline 1.832 & 0.21 & 0.16 & 0.26 & 0.38 & 0.24 & 0.33 & 0.21 & 0.21 & 0.13 & 0.20 & 0.34 & 0.42 & 0.49 & 0.17 & 0.14 & 0.13 & 0.13 & 0.19 & 0.20 \\
\hline 2.010 & 0.28 & 0.30 & 0.44 & 0.69 & 0.45 & 0.58 & 0.34 & 0.39 & 0.26 & 0.38 & 0.54 & 0.76 & 0.82 & 0.33 & 0.28 & 0.26 & 0.26 & 0.35 & 0.38 \\
\hline 2.207 & 0.35 & 0.43 & 0.61 & 0.99 & 0.65 & 0.80 & 0.46 & 0.58 & 0.40 & 0.57 & 0.73 & 1.09 & 1.13 & 0.51 & 0.44 & 0.39 & 0.39 & 0.52 & 0.58 \\
\hline 2.423 & 0.40 & 0.55 & 0.74 & 1.24 & 0.82 & 0.98 & 0.56 & 0.75 & 0.52 & 0.73 & 0.88 & 1.36 & 1.39 & 0.65 & 0.57 & 0.49 & 0.51 & 0.65 & 0.74 \\
\hline 2.660 & 0.43 & 0.65 & 0.85 & 1.44 & 0.94 & 1.11 & 0.64 & 0.88 & 0.60 & 0.86 & 0.99 & 1.58 & 1.61 & 0.77 & 0.67 & 0.57 & 0.61 & 0.75 & 0.88 \\
\hline 2.920 & 0.45 & 0.72 & 0.92 & 1.57 & 1.02 & 1.19 & 0.69 & 0.96 & 0.65 & 0.95 & 1.07 & 1.73 & 1.78 & 0.83 & 0.73 & 0.62 & 0.67 & 0.82 & 0.97 \\
\hline 3.206 & 0.45 & 0.77 & 0.97 & 1.65 & 1.05 & 1.22 & 0.72 & 1.01 & 0.67 & 1.01 & 1.11 & 1.82 & 1.89 & 0.87 & 0.76 & 0.64 & 0.70 & 0.86 & 1.02 \\
\hline 3.519 & 0.44 & 0.80 & 0.99 & 1.69 & 1.06 & 1.23 & 0.73 & 1.04 & 0.68 & 1.04 & 1.12 & 1.86 & 1.95 & 0.88 & 0.77 & 0.64 & 0.71 & 0.87 & 1.05 \\
\hline 3.862 & 0.43 & 0.81 & 0.99 & 1.71 & 1.07 & 1.22 & 0.73 & 1.05 & 0.68 & 1.07 & 1.12 & 1.88 & 1.99 & 0.88 & 0.77 & 0.64 & 0.72 & 0.87 & 1.07 \\
\hline 4.241 & 0.43 & 0.84 & 1.01 & 1.77 & 1.10 & 1.24 & 0.74 & 1.08 & 0.69 & 1.10 & 1.14 & 1.93 & 2.05 & 0.91 & 0.79 & 0.66 & 0.74 & 0.89 & 1.10 \\
\hline
\end{tabular}




\begin{tabular}{|c|c|c|c|c|c|c|c|c|c|c|c|c|c|c|c|c|c|c|c|}
\hline 4.656 & 0.43 & 0.86 & 1.03 & 1.83 & 1.14 & 1.26 & 0.76 & 1.11 & 0.72 & 1.14 & 1.17 & 1.99 & 2.11 & 0.94 & 0.82 & 0.68 & 0.77 & 0.91 & 1.14 \\
\hline 5.111 & 0.43 & 0.90 & 1.07 & 1.90 & 1.20 & 1.31 & 0.78 & 1.15 & 0.74 & 1.18 & 1.20 & 2.06 & 2.18 & 0.98 & 0.86 & 0.71 & 0.80 & 0.94 & 1.19 \\
\hline 5.611 & 0.43 & 0.91 & 1.07 & 1.94 & 1.22 & 1.32 & 0.78 & 1.15 & 0.75 & 1.19 & 1.21 & 2.08 & 2.20 & 1.00 & 0.87 & 0.72 & 0.81 & 0.95 & 1.21 \\
\hline 6.158 & 0.43 & 0.91 & 1.07 & 1.95 & 1.24 & 1.32 & 0.78 & 1.14 & 0.74 & 1.19 & 1.21 & 2.07 & 2.20 & 1.00 & 0.87 & 0.73 & 0.81 & 0.94 & 1.21 \\
\hline 6.761 & 0.42 & 0.90 & 1.06 & 1.92 & 1.24 & 1.30 & 0.76 & 1.10 & 0.72 & 1.16 & 1.19 & 2.03 & 2.17 & 0.99 & 0.85 & 0.72 & 0.80 & 0.92 & 1.19 \\
\hline 7.421 & 0.43 & 0.90 & 1.06 & 1.92 & 1.25 & 1.31 & 0.76 & 1.07 & 0.70 & 1.15 & 1.20 & 2.01 & 2.16 & 0.99 & 0.84 & 0.72 & 0.80 & 0.91 & 1.19 \\
\hline 8.147 & 0.44 & 0.93 & 1.08 & 1.93 & 1.27 & 1.32 & 0.77 & 1.05 & 0.68 & 1.14 & 1.21 & 2.02 & 2.16 & 1.01 & 0.84 & 0.73 & 0.81 & 0.91 & 1.20 \\
\hline 8.944 & 0.46 & 0.97 & 1.10 & 1.95 & 1.30 & 1.34 & 0.78 & 1.04 & 0.66 & 1.13 & 1.24 & 2.03 & 2.17 & 1.03 & 0.85 & 0.74 & 0.83 & 0.92 & 1.22 \\
\hline 9.819 & 0.48 & 1.03 & 1.15 & 1.98 & 1.34 & 1.39 & 0.80 & 1.04 & 0.65 & 1.14 & 1.28 & 2.07 & 2.20 & 1.08 & 0.87 & 0.76 & 0.86 & 0.95 & 1.26 \\
\hline 10.78 & 0.51 & 1.10 & 1.20 & 2.01 & 1.38 & 1.43 & 0.82 & 1.04 & 0.64 & 1.14 & 1.31 & 2.10 & 2.22 & 1.13 & 0.90 & 0.79 & 0.91 & 0.98 & 1.30 \\
\hline 11.83 & 0.56 & 1.21 & 1.29 & 2.09 & 1.45 & 1.52 & 0.87 & 1.07 & 0.65 & 1.18 & 1.39 & 2.19 & 2.28 & 1.22 & 0.95 & 0.84 & 0.99 & 1.03 & 1.38 \\
\hline 12.99 & 0.60 & 1.33 & 1.37 & 2.15 & 1.51 & 1.61 & 0.91 & 1.11 & 0.66 & 1.22 & 1.46 & 2.27 & 2.32 & 1.30 & 1.00 & 0.89 & 1.06 & 1.09 & 1.45 \\
\hline 14.26 & 0.65 & 1.46 & 1.47 & 2.23 & 1.58 & 1.70 & 0.96 & 1.15 & 0.69 & 1.27 & 1.53 & 2.36 & 2.38 & 1.39 & 1.06 & 0.94 & 1.15 & 1.15 & 1.52 \\
\hline 15.65 & 0.66 & 1.52 & 1.51 & 2.23 & 1.58 & 1.73 & 0.96 & 1.17 & 0.69 & 1.28 & 1.56 & 2.38 & 2.36 & 1.42 & 1.08 & 0.96 & 1.18 & 1.16 & 1.55 \\
\hline 17.17 & 0.65 & 1.53 & 1.51 & 2.15 & 1.51 & 1.69 & 0.93 & 1.13 & 0.66 & 1.25 & 1.53 & 2.31 & 2.27 & 1.39 & 1.05 & 0.93 & 1.16 & 1.13 & 1.51 \\
\hline 18.86 & 0.61 & 1.49 & 1.45 & 2.01 & 1.40 & 1.60 & 0.87 & 1.06 & 0.61 & 1.18 & 1.44 & 2.15 & 2.11 & 1.31 & 0.97 & 0.86 & 1.10 & 1.06 & 1.41 \\
\hline 20.70 & 0.56 & 1.46 & 1.41 & 1.86 & 1.28 & 1.48 & 0.81 & 0.96 & 0.55 & 1.09 & 1.33 & 1.96 & 1.92 & 1.21 & 0.89 & 0.79 & 1.02 & 0.97 & 1.29 \\
\hline 22.73 & 0.54 & 1.54 & 1.44 & 1.81 & 1.21 & 1.45 & 0.80 & 0.91 & 0.51 & 1.04 & 1.25 & 1.85 & 1.79 & 1.16 & 0.85 & 0.75 & 1.00 & 0.92 & 1.23 \\
\hline 24.95 & 0.57 & 1.78 & 1.56 & 1.86 & 1.22 & 1.49 & 0.84 & 0.92 & 0.51 & 1.04 & 1.24 & 1.83 & 1.74 & 1.19 & 0.86 & 0.77 & 1.05 & 0.93 & 1.24 \\
\hline 27.38 & 0.65 & 2.16 & 1.77 & 2.02 & 1.32 & 1.63 & 0.95 & 1.00 & 0.56 & 1.13 & 1.30 & 1.93 & 1.79 & 1.30 & 0.95 & 0.84 & 1.20 & 1.01 & 1.34 \\
\hline 30.07 & 0.75 & 2.58 & 1.98 & 2.20 & 1.45 & 1.81 & 1.09 & 1.12 & 0.63 & 1.25 & 1.40 & 2.09 & 1.89 & 1.44 & 1.08 & 0.94 & 1.41 & 1.13 & 1.49 \\
\hline 33.00 & 0.86 & 2.90 & 2.11 & 2.31 & 1.57 & 1.95 & 1.21 & 1.23 & 0.70 & 1.36 & 1.49 & 2.24 & 1.97 & 1.57 & 1.21 & 1.04 & 1.62 & 1.25 & 1.63 \\
\hline 36.24 & 0.93 & 2.98 & 2.09 & 2.28 & 1.62 & 1.99 & 1.27 & 1.30 & 0.74 & 1.42 & 1.53 & 2.30 & 1.97 & 1.63 & 1.29 & 1.10 & 1.79 & 1.33 & 1.71 \\
\hline 39.77 & 0.96 & 2.80 & 1.92 & 2.10 & 1.59 & 1.93 & 1.25 & 1.29 & 0.75 & 1.41 & 1.51 & 2.24 & 1.88 & 1.61 & 1.30 & 1.11 & 1.87 & 1.35 & 1.70 \\
\hline 43.66 & 0.95 & 2.41 & 1.65 & 1.83 & 1.50 & 1.79 & 1.17 & 1.24 & 0.72 & 1.34 & 1.44 & 2.09 & 1.71 & 1.54 & 1.26 & 1.08 & 1.88 & 1.33 & 1.63 \\
\hline 47.93 & 0.91 & 1.93 & 1.35 & 1.54 & 1.38 & 1.62 & 1.06 & 1.16 & 0.69 & 1.25 & 1.36 & 1.92 & 1.52 & 1.44 & 1.19 & 1.03 & 1.85 & 1.29 & 1.52 \\
\hline 52.63 & 0.86 & 1.49 & 1.09 & 1.31 & 1.27 & 1.46 & 0.94 & 1.09 & 0.66 & 1.18 & 1.29 & 1.76 & 1.36 & 1.35 & 1.12 & 0.99 & 1.82 & 1.27 & 1.43 \\
\hline 57.77 & 0.82 & 1.14 & 0.90 & 1.16 & 1.19 & 1.34 & 0.85 & 1.05 & 0.65 & 1.14 & 1.25 & 1.65 & 1.25 & 1.28 & 1.06 & 0.96 & 1.78 & 1.27 & 1.36 \\
\hline
\end{tabular}




\begin{tabular}{|c|c|c|c|c|c|c|c|c|c|c|c|c|c|c|c|c|c|c|c|}
\hline 63.41 & 0.79 & 0.92 & 0.78 & 1.06 & 1.12 & 1.24 & 0.78 & 1.02 & 0.65 & 1.11 & 1.23 & 1.58 & 1.18 & 1.22 & 1.02 & 0.94 & 1.76 & 1.29 & 1.31 \\
\hline 69.62 & 0.77 & 0.80 & 0.72 & 1.00 & 1.07 & 1.16 & 0.72 & 1.01 & 0.66 & 1.10 & 1.22 & 1.53 & 1.14 & 1.17 & 0.98 & 0.92 & 1.72 & 1.33 & 1.27 \\
\hline 76.43 & 0.74 & 0.74 & 0.67 & 0.94 & 1.00 & 1.07 & 0.67 & 0.99 & 0.66 & 1.09 & 1.20 & 1.47 & 1.09 & 1.11 & 0.94 & 0.90 & 1.66 & 1.34 & 1.23 \\
\hline 83.90 & 0.71 & 0.69 & 0.62 & 0.87 & 0.93 & 0.98 & 0.62 & 0.96 & 0.65 & 1.05 & 1.16 & 1.37 & 1.01 & 1.03 & 0.89 & 0.85 & 1.56 & 1.34 & 1.17 \\
\hline 92.09 & 0.66 & 0.64 & 0.56 & 0.79 & 0.86 & 0.89 & 0.57 & 0.92 & 0.63 & 1.01 & 1.11 & 1.25 & 0.91 & 0.94 & 0.84 & 0.81 & 1.43 & 1.32 & 1.10 \\
\hline 101.1 & 0.61 & 0.59 & 0.49 & 0.72 & 0.80 & 0.81 & 0.54 & 0.87 & 0.60 & 0.96 & 1.06 & 1.11 & 0.81 & 0.85 & 0.79 & 0.76 & 1.29 & 1.30 & 1.03 \\
\hline 111.0 & 0.57 & 0.56 & 0.44 & 0.68 & 0.76 & 0.76 & 0.53 & 0.84 & 0.59 & 0.94 & 1.01 & 0.98 & 0.72 & 0.78 & 0.75 & 0.74 & 1.17 & 1.29 & 0.99 \\
\hline 121.8 & 0.54 & 0.54 & 0.41 & 0.68 & 0.75 & 0.75 & 0.53 & 0.81 & 0.58 & 0.93 & 0.99 & 0.89 & 0.67 & 0.74 & 0.74 & 0.74 & 1.08 & 1.31 & 0.96 \\
\hline 133.7 & 0.52 & 0.55 & 0.40 & 0.69 & 0.76 & 0.76 & 0.54 & 0.81 & 0.59 & 0.96 & 0.99 & 0.85 & 0.66 & 0.72 & 0.76 & 0.77 & 1.03 & 1.35 & 0.95 \\
\hline 146.8 & 0.52 & 0.60 & 0.43 & 0.73 & 0.78 & 0.79 & 0.57 & 0.84 & 0.63 & 1.02 & 1.02 & 0.84 & 0.69 & 0.74 & 0.81 & 0.83 & 1.01 & 1.41 & 0.96 \\
\hline 161.2 & 0.54 & 0.67 & 0.47 & 0.78 & 0.83 & 0.84 & 0.60 & 0.88 & 0.69 & 1.10 & 1.07 & 0.86 & 0.74 & 0.77 & 0.87 & 0.89 & 1.00 & 1.45 & 0.98 \\
\hline 176.8 & 0.56 & 0.74 & 0.51 & 0.81 & 0.88 & 0.89 & 0.64 & 0.95 & 0.77 & 1.19 & 1.14 & 0.86 & 0.79 & 0.81 & 0.93 & 0.93 & 0.98 & 1.44 & 0.98 \\
\hline 194.2 & 0.57 & 0.78 & 0.54 & 0.81 & 0.91 & 0.91 & 0.67 & 1.00 & 0.84 & 1.25 & 1.19 & 0.82 & 0.81 & 0.81 & 0.94 & 0.94 & 0.91 & 1.36 & 0.95 \\
\hline 213.2 & 0.57 & 0.77 & 0.52 & 0.74 & 0.90 & 0.86 & 0.68 & 1.00 & 0.88 & 1.25 & 1.18 & 0.70 & 0.75 & 0.76 & 0.90 & 0.89 & 0.78 & 1.21 & 0.86 \\
\hline 234.1 & 0.54 & 0.69 & 0.44 & 0.60 & 0.80 & 0.73 & 0.64 & 0.93 & 0.86 & 1.16 & 1.08 & 0.49 & 0.60 & 0.64 & 0.80 & 0.80 & 0.61 & 1.00 & 0.71 \\
\hline 256.8 & 0.49 & 0.54 & 0.33 & 0.42 & 0.65 & 0.54 & 0.56 & 0.76 & 0.80 & 0.99 & 0.92 & 0.25 & 0.40 & 0.48 & 0.65 & 0.68 & 0.43 & 0.78 & 0.51 \\
\hline 282.1 & 0.46 & 0.39 & 0.23 & 0.26 & 0.48 & 0.38 & 0.47 & 0.56 & 0.75 & 0.79 & 0.76 & 0.08 & 0.23 & 0.34 & 0.51 & 0.59 & 0.30 & 0.62 & 0.35 \\
\hline 309.6 & 0.46 & 0.31 & 0.17 & 0.19 & 0.38 & 0.29 & 0.40 & 0.41 & 0.74 & 0.66 & 0.65 & 0.03 & 0.14 & 0.27 & 0.43 & 0.56 & 0.25 & 0.55 & 0.26 \\
\hline 339.8 & 0.53 & 0.32 & 0.18 & 0.23 & 0.38 & 0.31 & 0.39 & 0.38 & 0.84 & 0.65 & 0.65 & 0.04 & 0.16 & 0.31 & 0.45 & 0.62 & 0.31 & 0.60 & 0.29 \\
\hline 373.1 & 0.69 & 0.48 & 0.29 & 0.38 & 0.54 & 0.44 & 0.48 & 0.51 & 1.04 & 0.80 & 0.79 & 0.18 & 0.30 & 0.47 & 0.57 & 0.79 & 0.51 & 0.79 & 0.44 \\
\hline 409.6 & 0.97 & 0.80 & 0.51 & 0.65 & 0.86 & 0.68 & 0.69 & 0.84 & 1.36 & 1.11 & 1.05 & 0.46 & 0.56 & 0.78 & 0.83 & 1.07 & 0.85 & 1.12 & 0.72 \\
\hline 449.7 & 1.36 & 1.27 & 0.87 & 0.97 & 1.32 & 0.97 & 1.05 & 1.37 & 1.75 & 1.55 & 1.38 & 0.78 & 0.88 & 1.19 & 1.22 & 1.45 & 1.31 & 1.55 & 1.08 \\
\hline 493.6 & 1.86 & 1.78 & 1.32 & 1.26 & 1.85 & 1.24 & 1.57 & 2.02 & 2.19 & 2.03 & 1.72 & 1.00 & 1.13 & 1.63 & 1.72 & 1.89 & 1.82 & 2.03 & 1.46 \\
\hline 541.9 & 2.44 & 2.28 & 1.85 & 1.48 & 2.34 & 1.45 & 2.22 & 2.65 & 2.64 & 2.47 & 2.03 & 1.09 & 1.23 & 2.06 & 2.28 & 2.37 & 2.32 & 2.51 & 1.79 \\
\hline 594.9 & 3.09 & 2.69 & 2.43 & 1.61 & 2.76 & 1.62 & 2.97 & 3.18 & 3.11 & 2.81 & 2.31 & 1.08 & 1.20 & 2.44 & 2.89 & 2.88 & 2.78 & 2.95 & 2.07 \\
\hline 653.0 & 3.81 & 3.02 & 3.03 & 1.71 & 3.09 & 1.83 & 3.78 & 3.56 & 3.64 & 3.07 & 2.61 & 1.05 & 1.13 & 2.80 & 3.52 & 3.41 & 3.17 & 3.33 & 2.34 \\
\hline 716.9 & 4.57 & 3.27 & 3.62 & 1.80 & 3.33 & 2.11 & 4.57 & 3.78 & 4.23 & 3.24 & 2.94 & 1.06 & 1.08 & 3.13 & 4.11 & 3.94 & 3.46 & 3.61 & 2.62 \\
\hline 786.9 & 5.29 & 3.44 & 4.11 & 1.89 & 3.49 & 2.47 & 5.23 & 3.87 & 4.83 & 3.35 & 3.28 & 1.17 & 1.13 & 3.45 & 4.58 & 4.41 & 3.61 & 3.75 & 2.91 \\
\hline 863.9 & 5.90 & 3.50 & 4.42 & 1.95 & 3.57 & 2.85 & 5.65 & 3.86 & 5.37 & 3.38 & 3.52 & 1.35 & 1.27 & 3.72 & 4.85 & 4.75 & 3.57 & 3.72 & 3.17 \\
\hline
\end{tabular}




\begin{tabular}{|l|l|l|l|l|l|l|l|l|l|l|l|l|l|l|l|l|l|l|l|l|}
\hline 948.2 & 6.28 & 3.43 & 4.48 & 1.91 & 3.53 & 3.18 & 5.73 & 3.77 & 5.71 & 3.30 & 3.51 & 1.21 & 1.44 & 3.88 & 4.86 & 4.89 & 3.36 & 3.50 & 3.35 \\
\hline 1041 & 6.35 & 3.20 & 4.28 & 1.71 & 3.34 & 3.33 & 5.46 & 3.61 & 5.74 & 3.11 & 3.18 & 0.74 & 1.51 & 3.87 & 4.59 & 4.78 & 3.01 & 3.09 & 3.36 \\
\hline 1143 & 6.09 & 2.84 & 3.83 & 1.19 & 3.00 & 3.26 & 4.89 & 3.36 & 5.43 & 2.77 & 2.52 & 0.19 & 1.18 & 3.66 & 4.10 & 4.47 & 2.62 & 2.59 & 3.17 \\
\hline 1255 & 5.49 & 2.35 & 3.22 & 0.58 & 2.53 & 2.98 & 4.13 & 2.97 & 4.79 & 2.32 & 1.65 & 0.02 & 0.63 & 3.24 & 3.46 & 3.98 & 2.27 & 2.04 & 2.78 \\
\hline 1377 & 4.63 & 1.81 & 2.50 & 0.13 & 1.69 & 2.13 & 3.29 & 2.42 & 3.94 & 1.76 & 0.81 & 0.00 & 0.15 & 2.67 & 2.76 & 3.40 & 2.02 & 1.53 & 2.21 \\
\hline 1512 & 3.58 & 1.27 & 1.75 & 0.01 & 0.81 & 1.07 & 2.45 & 1.70 & 2.98 & 1.13 & 0.26 & 0.00 & 0.02 & 2.03 & 2.07 & 2.79 & 1.85 & 1.12 & 1.53 \\
\hline 1660 & 2.76 & 0.89 & 1.21 & 0.00 & 0.18 & 0.25 & 1.86 & 1.15 & 2.27 & 0.69 & 0.04 & 0.00 & 0.00 & 1.56 & 1.59 & 2.34 & 1.76 & 0.86 & 1.03 \\
\hline 1822 & 2.00 & 0.59 & 0.73 & 0.00 & 0.02 & 0.03 & 1.35 & 0.59 & 1.65 & 0.29 & 0.00 & 0.00 & 0.00 & 1.18 & 1.23 & 2.03 & 1.79 & 0.76 & 0.57 \\
\hline
\end{tabular}

\begin{tabular}{|c|c|c|c|c|c|c|c|c|c|}
\hline $\begin{array}{l}\text { DO3A sample } \\
\text { position }\end{array}$ & $\begin{array}{c}<0.5 \\
\mathrm{~mm}(\mathrm{~g})\end{array}$ & $\begin{array}{c}0.5-2 \\
\mathrm{~mm} \\
(\mathrm{~g})\end{array}$ & $\begin{array}{c}>2 \\
\mathrm{~mm} \\
(\mathrm{~g})\end{array}$ & Clast \# & $\begin{array}{l}\text { wt } \% \\
\text { fine }\end{array}$ & $\begin{array}{l}\text { wt } \% \\
\text { coarse }\end{array}$ & $\begin{array}{c}\text { wt \% } \\
> \\
2 \mathrm{~mm}\end{array}$ & $\begin{array}{c}\text { LPS } \\
\text { mean } \\
(\mu \mathrm{m})\end{array}$ & $\begin{array}{l}\text { LPS \% } \\
\text { mud }\end{array}$ \\
\hline $30 \mathrm{~cm}$ & 31.02 & 26.39 & 241.38 & 89 & 10.38 & 8.83 & 80.79 & 723 & 21.5 \\
\hline $60 \mathrm{~cm}$ & 66.36 & 15.44 & 132.9 & 37 & 30.91 & 7.19 & 61.90 & 393.1 & 49 \\
\hline $90 \mathrm{~cm}$ & 80.03 & 13.52 & 71.74 & 21 & 48.42 & 8.18 & 43.40 & 462.7 & 46.5 \\
\hline $120 \mathrm{~cm}$ & 42.79 & 12.04 & 219.58 & 88 & 15.59 & 4.39 & 80.02 & 185.1 & 67.6 \\
\hline $150 \mathrm{~cm}$ & 39.16 & 7.46 & 208.76 & 79 & 15.33 & 2.92 & 81.74 & 373.1 & 46.5 \\
\hline $180 \mathrm{~cm}$ & 61.5 & 14.31 & 31.48 & 21 & 57.32 & 13.34 & 29.34 & 340 & 52.9 \\
\hline $210 \mathrm{~cm}$ & 67.76 & 19.74 & 78.49 & 29 & 40.82 & 11.89 & 47.29 & 602.2 & 31.4 \\
\hline $240 \mathrm{~cm}$ & 74.82 & 15.42 & 69.47 & 22 & 46.85 & 9.65 & 43.50 & 458.8 & 38.7 \\
\hline $270 \mathrm{~cm}$ & 35.17 & 28.53 & 261.98 & 94 & 10.80 & 8.76 & 80.44 & 660.01 & 23.8 \\
\hline $300 \mathrm{~cm}$ & 37.79 & 17.73 & 54.02 & 32 & 34.50 & 16.19 & 49.32 & 392.3 & 41.4 \\
\hline $330 \mathrm{~cm}$ & 29.96 & 16.79 & 77.23 & 48 & 24.17 & 13.54 & 62.29 & 326.7 & 46.6 \\
\hline $360 \mathrm{~cm}$ & 59.62 & 18.26 & 33.98 & 36 & 53.30 & 16.32 & 30.38 & 117.7 & 72.4 \\
\hline $390 \mathrm{~cm}$ & 84.17 & 4.01 & 4.51 & 3 & 90.81 & 4.33 & 4.87 & 151.4 & 71.5 \\
\hline $420 \mathrm{~cm}$ & 57.21 & 14.86 & 97.3 & 32 & 33.78 & 8.77 & 57.45 & 468.3 & 41.6 \\
\hline $450 \mathrm{~cm}$ & 61.57 & 15.09 & 90.19 & 29 & 36.90 & 9.04 & 54.05 & 535.7 & 33.6 \\
\hline $480 \mathrm{~cm}$ & 75.11 & 23.46 & 35.95 & 26 & 55.84 & 17.44 & 26.72 & 598.4 & 29 \\
\hline $510 \mathrm{~cm}$ & 42.51 & 7.88 & 144.23 & 48 & 21.84 & 4.05 & 74.11 & 447.5 & 38.4 \\
\hline $540 \mathrm{~cm}$ & 40.88 & 21.01 & 225.28 & 55 & 14.24 & 7.32 & 78.45 & 410.6 & 36.7 \\
\hline
\end{tabular}




\begin{tabular}{|l|l|l|l|l|l|l|l|l|l|}
\hline $\mathbf{5 7 0} \mathrm{cm}$ & 50.69 & 15.98 & 41.58 & 33 & 46.83 & 14.76 & 38.41 & 392.1 & 46.3 \\
\hline
\end{tabular}

\begin{tabular}{|c|c|c|c|c|c|c|c|}
\hline $\begin{array}{l}\text { Diameter } \\
(\mu \mathrm{m})\end{array}$ & $\begin{array}{l}30 \\
\mathrm{~cm}\end{array}$ & $\begin{array}{l}60 \\
\mathrm{~cm}\end{array}$ & $\begin{array}{l}90 \\
\mathrm{~cm}\end{array}$ & $\begin{array}{l}120 \\
\mathrm{~cm}\end{array}$ & $\begin{array}{l}150 \\
\mathrm{~cm}\end{array}$ & $\begin{array}{l}180 \\
\mathrm{~cm}\end{array}$ & $\begin{array}{l}210 \\
\mathrm{~cm}\end{array}$ \\
\hline 0.375 & 0.00 & 0.00 & 0.00 & 0.00 & 0.00 & 0.00 & 0.00 \\
\hline 0.412 & 0.00 & 0.00 & 0.00 & 0.00 & 0.00 & 0.00 & 0.00 \\
\hline 0.452 & 0.00 & 0.00 & 0.00 & 0.00 & 0.00 & 0.00 & 0.00 \\
\hline 0.496 & 0.00 & 0.00 & 0.00 & 0.00 & 0.00 & 0.00 & 0.00 \\
\hline 0.545 & 0.00 & 0.00 & 0.00 & 0.00 & 0.00 & 0.00 & 0.00 \\
\hline 0.598 & 0.00 & 0.00 & 0.00 & 0.00 & 0.00 & 0.00 & 0.00 \\
\hline 0.657 & 0.00 & 0.00 & 0.00 & 0.00 & 0.00 & 0.00 & 0.00 \\
\hline 0.721 & 0.00 & 0.00 & 0.00 & 0.00 & 0.00 & 0.00 & 0.00 \\
\hline 0.791 & 0.00 & 0.00 & 0.00 & 0.00 & 0.00 & 0.00 & 0.00 \\
\hline 0.869 & 0.00 & 0.00 & 0.00 & 0.00 & 0.00 & 0.00 & 0.00 \\
\hline 0.953 & 0.00 & 0.00 & 0.00 & 0.00 & 0.00 & 0.00 & 0.00 \\
\hline 1.047 & 0.00 & 0.00 & 0.00 & 0.00 & 0.00 & 0.00 & 0.00 \\
\hline 1.149 & 0.00 & 0.00 & 0.00 & 0.00 & 0.00 & 0.00 & 0.00 \\
\hline 1.261 & 0.00 & 0.00 & 0.00 & 0.00 & 0.00 & 0.00 & 0.00 \\
\hline 1.385 & 0.00 & 0.00 & 0.00 & 0.00 & 0.00 & 0.00 & 0.00 \\
\hline 1.520 & 0.00 & 0.00 & 0.00 & 0.00 & 0.01 & 0.00 & 0.00 \\
\hline 1.669 & 0.02 & 0.02 & 0.01 & 0.00 & 0.04 & 0.01 & 0.00 \\
\hline 1.832 & 0.08 & 0.07 & 0.03 & 0.02 & 0.11 & 0.06 & 0.00 \\
\hline 2.010 & 0.16 & 0.14 & 0.08 & 0.06 & 0.22 & 0.16 & 0.06 \\
\hline 2.207 & 0.25 & 0.22 & 0.14 & 0.11 & 0.34 & 0.30 & 0.16 \\
\hline 2.423 & 0.33 & 0.29 & 0.20 & 0.17 & 0.45 & 0.42 & 0.24 \\
\hline 2.660 & 0.40 & 0.35 & 0.26 & 0.22 & 0.52 & 0.53 & 0.28 \\
\hline 2.920 & 0.44 & 0.38 & 0.30 & 0.25 & 0.57 & 0.60 & 0.27 \\
\hline 3.206 & 0.46 & 0.41 & 0.34 & 0.28 & 0.59 & 0.64 & 0.21 \\
\hline
\end{tabular}




\begin{tabular}{|c|c|c|c|c|c|c|c|}
\hline 3.519 & 0.47 & 0.42 & 0.37 & 0.30 & 0.60 & 0.67 & 0.14 \\
\hline 3.862 & 0.48 & 0.43 & 0.39 & 0.32 & 0.60 & 0.70 & 0.11 \\
\hline 4.241 & 0.49 & 0.44 & 0.43 & 0.34 & 0.62 & 0.74 & 0.14 \\
\hline 4.656 & 0.51 & 0.45 & 0.46 & 0.37 & 0.64 & 0.79 & 0.23 \\
\hline 5.111 & 0.53 & 0.47 & 0.49 & 0.40 & 0.67 & 0.85 & 0.34 \\
\hline 5.611 & 0.53 & 0.47 & 0.51 & 0.41 & 0.69 & 0.88 & 0.41 \\
\hline 6.158 & 0.53 & 0.47 & 0.52 & 0.42 & 0.69 & 0.89 & 0.41 \\
\hline 6.761 & 0.52 & 0.46 & 0.52 & 0.43 & 0.68 & 0.89 & 0.38 \\
\hline 7.421 & 0.52 & 0.46 & 0.53 & 0.43 & 0.68 & 0.90 & 0.34 \\
\hline 8.147 & 0.53 & 0.47 & 0.54 & 0.45 & 0.69 & 0.91 & 0.32 \\
\hline 8.944 & 0.54 & 0.48 & 0.55 & 0.46 & 0.70 & 0.93 & 0.32 \\
\hline 9.819 & 0.57 & 0.51 & 0.56 & 0.49 & 0.73 & 0.96 & 0.34 \\
\hline 10.78 & 0.60 & 0.54 & 0.57 & 0.51 & 0.76 & 0.99 & 0.36 \\
\hline 11.83 & 0.65 & 0.60 & 0.59 & 0.55 & 0.80 & 1.04 & 0.38 \\
\hline 12.99 & 0.71 & 0.65 & 0.61 & 0.59 & 0.85 & 1.08 & 0.41 \\
\hline 14.26 & 0.77 & 0.71 & 0.63 & 0.64 & 0.89 & 1.12 & 0.46 \\
\hline 15.65 & 0.81 & 0.74 & 0.63 & 0.66 & 0.90 & 1.13 & 0.50 \\
\hline 17.17 & 0.81 & 0.75 & 0.61 & 0.65 & 0.87 & 1.09 & 0.50 \\
\hline 18.86 & 0.77 & 0.72 & 0.57 & 0.62 & 0.81 & 1.02 & 0.43 \\
\hline 20.70 & 0.73 & 0.68 & 0.52 & 0.58 & 0.74 & 0.92 & 0.31 \\
\hline 22.73 & 0.71 & 0.66 & 0.49 & 0.57 & 0.69 & 0.84 & 0.20 \\
\hline 24.95 & 0.73 & 0.68 & 0.51 & 0.59 & 0.68 & 0.81 & 0.21 \\
\hline 27.38 & 0.81 & 0.75 & 0.57 & 0.66 & 0.72 & 0.82 & 0.36 \\
\hline 30.07 & 0.91 & 0.84 & 0.66 & 0.75 & 0.79 & 0.85 & 0.52 \\
\hline 33.00 & 1.02 & 0.93 & 0.76 & 0.85 & 0.85 & 0.87 & 0.48 \\
\hline 36.24 & 1.11 & 0.99 & 0.84 & 0.92 & 0.88 & 0.87 & 0.34 \\
\hline
\end{tabular}




\begin{tabular}{|c|c|c|c|c|c|c|c|}
\hline 39.77 & 1.14 & 1.01 & 0.88 & 0.95 & 0.88 & 0.82 & 0.30 \\
\hline 43.66 & 1.14 & 0.99 & 0.89 & 0.95 & 0.85 & 0.75 & 0.37 \\
\hline 47.93 & 1.10 & 0.96 & 0.89 & 0.94 & 0.81 & 0.68 & 0.41 \\
\hline 52.63 & 1.06 & 0.93 & 0.88 & 0.94 & 0.78 & 0.62 & 0.33 \\
\hline 57.77 & 1.04 & 0.92 & 0.89 & 0.95 & 0.76 & 0.59 & 0.27 \\
\hline 63.41 & 1.03 & 0.93 & 0.90 & 0.97 & 0.76 & 0.58 & 0.32 \\
\hline 69.62 & 1.03 & 0.95 & 0.93 & 0.99 & 0.76 & 0.58 & 0.39 \\
\hline 76.43 & 1.04 & 0.97 & 0.95 & 1.01 & 0.76 & 0.57 & 0.39 \\
\hline 83.90 & 1.06 & 0.99 & 0.97 & 1.02 & 0.75 & 0.55 & 0.35 \\
\hline 92.09 & 1.06 & 0.99 & 0.99 & 1.03 & 0.75 & 0.53 & 0.32 \\
\hline 101.1 & 1.06 & 1.00 & 1.01 & 1.04 & 0.74 & 0.52 & 0.33 \\
\hline 111.0 & 1.06 & 1.02 & 1.05 & 1.07 & 0.77 & 0.53 & 0.39 \\
\hline 121.8 & 1.06 & 1.06 & 1.13 & 1.14 & 0.81 & 0.57 & 0.49 \\
\hline 133.7 & 1.08 & 1.13 & 1.25 & 1.25 & 0.89 & 0.63 & 0.59 \\
\hline 146.8 & 1.14 & 1.23 & 1.41 & 1.39 & 0.99 & 0.73 & 0.67 \\
\hline 161.2 & 1.23 & 1.35 & 1.58 & 1.54 & 1.10 & 0.85 & 0.85 \\
\hline 176.8 & 1.35 & 1.47 & 1.75 & 1.67 & 1.23 & 1.00 & 1.09 \\
\hline 194.2 & 1.49 & 1.55 & 1.88 & 1.77 & 1.34 & 1.14 & 1.28 \\
\hline 213.2 & 1.60 & 1.59 & 1.96 & 1.80 & 1.44 & 1.28 & 1.40 \\
\hline 234.1 & 1.68 & 1.57 & 1.98 & 1.80 & 1.50 & 1.38 & 1.57 \\
\hline 256.8 & 1.74 & 1.52 & 1.98 & 1.79 & 1.52 & 1.47 & 1.84 \\
\hline 282.1 & 1.82 & 1.49 & 2.00 & 1.84 & 1.55 & 1.57 & 2.11 \\
\hline 309.6 & 1.98 & 1.54 & 2.09 & 1.96 & 1.61 & 1.72 & 2.35 \\
\hline 339.8 & 2.24 & 1.70 & 2.28 & 2.17 & 1.76 & 1.95 & 2.54 \\
\hline 373.1 & 2.61 & 1.99 & 2.54 & 2.45 & 2.02 & 2.30 & 2.74 \\
\hline 409.6 & 3.04 & 2.36 & 2.85 & 2.73 & 2.41 & 2.74 & 3.08 \\
\hline 449.7 & 3.43 & 2.76 & 3.13 & 2.94 & 2.90 & 3.23 & 3.68 \\
\hline
\end{tabular}




\begin{tabular}{|l|l|l|l|l|l|l|l|}
\hline 493.6 & 3.71 & 3.11 & 3.32 & 3.05 & 3.44 & 3.71 & 4.58 \\
\hline 541.9 & 3.81 & 3.37 & 3.40 & 3.05 & 3.93 & 4.12 & 5.61 \\
\hline 594.9 & 3.76 & 3.55 & 3.40 & 3.00 & 4.31 & 4.41 & 6.25 \\
\hline 653.0 & 3.63 & 3.70 & 3.37 & 2.98 & 4.53 & 4.58 & 6.29 \\
\hline 716.9 & 3.49 & 3.85 & 3.35 & 3.03 & 4.55 & 4.62 & 6.47 \\
\hline 786.9 & 3.41 & 4.03 & 3.37 & 3.15 & 4.38 & 4.52 & 6.90 \\
\hline 863.9 & 3.37 & 4.18 & 3.42 & 3.31 & 4.05 & 4.25 & 6.03 \\
\hline 948.2 & 3.30 & 4.23 & 3.43 & 3.46 & 3.61 & 3.79 & 4.00 \\
\hline 1041 & 3.14 & 4.06 & 3.35 & 3.51 & 3.08 & 3.14 & 3.30 \\
\hline 1143 & 2.82 & 3.66 & 3.14 & 3.44 & 2.55 & 2.39 & 3.72 \\
\hline 1255 & 2.33 & 3.02 & 2.80 & 3.24 & 2.04 & 1.63 & 2.03 \\
\hline 1377 & 1.71 & 2.28 & 2.35 & 2.92 & 1.61 & 1.01 & 0.69 \\
\hline 1512 & 1.02 & 1.56 & 1.85 & 2.53 & 1.28 & 0.64 & 1.56 \\
\hline 1660 & 0.55 & 1.06 & 1.46 & 2.20 & 1.07 & 0.45 & 1.77 \\
\hline 1822 & 0.17 & 0.74 & 1.18 & 1.96 & 1.05 & 0.54 & 0.22 \\
\hline
\end{tabular}

\begin{tabular}{|c|c|c|c|c|c|c|c|c|c|}
\hline $\begin{array}{l}\text { B01AB } \\
\text { Sample } \\
\text { Position }\end{array}$ & $\begin{array}{c}<0.5 \\
\mathrm{~mm}(\mathrm{~g})\end{array}$ & $\begin{array}{c}0.5-2 \\
\mathrm{~mm} \\
(\mathrm{~g})\end{array}$ & $\begin{array}{l}>2 \\
\mathrm{~mm} \\
(\mathrm{~g})\end{array}$ & Clast \# & $\begin{array}{l}\text { wt } \% \\
\text { fine }\end{array}$ & $\begin{array}{l}\text { wt } \% \\
\text { coarse }\end{array}$ & $\begin{array}{c}\text { wt \% } \\
> \\
2 \mathrm{~mm}\end{array}$ & $\begin{array}{c}\text { LPS } \\
\text { mean } \\
(\mu \mathrm{m})\end{array}$ & $\begin{array}{c}\text { LPS } \\
\% \\
\text { mud }\end{array}$ \\
\hline $30 \mathrm{~cm}$ & 61.23 & 38.72 & 62.46 & 45 & 37.70 & 23.84 & 38.46 & 455.6 & 24.8 \\
\hline $60 \mathrm{~cm}$ & 68.39 & 47.66 & 122.95 & 42 & 28.62 & 19.94 & 51.44 & 525.2 & 22.3 \\
\hline $90 \mathrm{~cm}$ & 58.45 & 46.78 & 121.12 & 56 & 25.82 & 20.67 & 53.51 & 519.5 & 20.1 \\
\hline $120 \mathrm{~cm}$ & 52.7 & 31.56 & 338.74 & 78 & 12.46 & 7.46 & 80.08 & 559.7 & 19.6 \\
\hline $150 \mathrm{~cm}$ & 50.04 & 28.13 & 181.86 & 43 & 19.24 & 10.82 & 69.94 & 494 & 25.6 \\
\hline $180 \mathrm{~cm}$ & 74.89 & 40.67 & 355.16 & 57 & 15.91 & 8.64 & 75.45 & 457.8 & 29.7 \\
\hline $210 \mathrm{~cm}$ & 102.36 & 75.18 & 102.89 & 41 & 36.50 & 26.81 & 36.69 & 604.1 & 11.8 \\
\hline
\end{tabular}




\section{$\underline{\text { Appendix B }}$}

Appendix B presents the results from quantitative assessment of microfossils found in Facies 1-6. Information includes the total number of specimens identified and percent planktonic foraminifera.

\begin{tabular}{|c|c|c|c|c|c|c|c|c|}
\hline Microfossils & $\begin{array}{c}\text { Facies } \\
1\end{array}$ & $\begin{array}{c}\text { Facies } \\
2\end{array}$ & $\begin{array}{c}\text { Facies } \\
3\end{array}$ & $\begin{array}{c}\text { Facies } \\
4\end{array}$ & $\begin{array}{c}\text { Facies } \\
5\end{array}$ & $\begin{array}{c}\text { Facies } \\
6\end{array}$ & $\begin{array}{c}\text { BO1AB } \\
120 \mathrm{~cm} \\
\text { Facies } \\
4\end{array}$ & $\begin{array}{c}\text { BO1AB } \\
180 \mathrm{~cm} \\
\text { Facies } 5\end{array}$ \\
\hline Patellina antarctica & 10 & 12 & 7 & 7 & 0 & 0 & 0 & 0 \\
\hline Astrononion antarcticus & 4 & 3 & 3 & 6 & 5 & 0 & 0 & 1 \\
\hline Parafissurina fusuliformis & 6 & 13 & 10 & 10 & 2 & 0 & 0 & 0 \\
\hline Parafissurina lateralis & 6 & 14 & 0 & 2 & 2 & 3 & 0 & 0 \\
\hline Oolina apipleura & 8 & 9 & 5 & 1 & 4 & 1 & 0 & 0 \\
\hline Oolina hexagona & 17 & 2 & 10 & 1 & 11 & 2 & 0 & 0 \\
\hline Lagena sp. A & 4 & 3 & 1 & 7 & 4 & 1 & 0 & 0 \\
\hline Cassidulinoides porrectus & 0 & 2 & 0 & 0 & 0 & 0 & 0 & 0 \\
\hline Trifarina pauperata & 21 & 20 & 14 & 42 & 68 & 4 & 0 & 0 \\
\hline Gavelinopsis cf. "longwoodensis" & 3 & 0 & 2 & 0 & 0 & 0 & 0 & 0 \\
\hline Cornuspiroides expansus & 16 & 3 & 17 & 0 & 1 & 3 & 0 & 0 \\
\hline Cibicides sp. & 12 & 92 & 48 & 41 & 71 & 11 & 3 & 10 \\
\hline Globocassidulina subglossa & 8 & 17 & 13 & 11 & 14 & 5 & 0 & 2 \\
\hline Ehrenbergina glabra & 49 & 77 & 48 & 57 & 134 & 13 & 2 & 11 \\
\hline Biloculina/Pyrgo cf. tasmanensis & 1 & 5 & 2 & 1 & 3 & 0 & 0 & 1 \\
\hline Pseudopolymorphina tortuosa & 1 & 0 & 0 & 4 & 0 & 0 & 0 & 0 \\
\hline Quinqueloculina cf. suborbicularis & 13 & 20 & 15 & 19 & 10 & 0 & 0 & 0 \\
\hline Quinqueloculina sp. & 0 & 0 & 0 & 0 & 0 & 1 & 0 & 0 \\
\hline Lenticulina gibba & 29 & 22 & 11 & 29 & 11 & 2 & 0 & 0 \\
\hline Anomalinoides sp. & 0 & 0 & 0 & 0 & 0 & 0 & 0 & 0 \\
\hline Ceratobulimina sp. & 5 & 4 & 2 & 3 & 0 & 0 & 0 & 0 \\
\hline Neogloboquadrina pachyderma & 21 & 5 & 2 & 9 & 4 & 0 & 0 & 0 \\
\hline Polychaete tubes & 2 & 13 & 9 & 10 & 4 & 3 & 7 & 7 \\
\hline Sponge spicules & 16 & 27 & 10 & 27 & 21 & 12 & 0 & 15 \\
\hline Microalgae & 51 & 14 & 0 & 7 & 0 & 5 & 0 & 2 \\
\hline Marine frags e.g. shell hash, bryozoa & 22 & 86 & 40 & 31 & 53 & 20 & 5 & 22 \\
\hline Total number of specimens & 234 & 317 & 269 & 250 & 344 & 46 & 17 & 71 \\
\hline Sample weight & 4.24 & 8.34 & 10.36 & 6.72 & 18.04 & 6.70 & 19.71 & 20.04 \\
\hline Specimens per gram & 55.19 & 38.01 & 25.97 & 37.20 & 19.07 & 6.87 & 0.86 & 3.54 \\
\hline$\%$ planktic forams & 8.97 & 1.58 & 0.74 & 3.60 & 1.16 & 0.00 & 0.00 & 0.00 \\
\hline
\end{tabular}




\section{$\underline{\text { Appendix C }}$}

\section{Lithologic Units}

The following appendix contains field descriptions for lithostratigraphic subdivisions identified throughout glacimarine sequences DO1A/3A and BO1A/B. Up to 12 major changes in lithology are distinguished based on a range of different sedimentological features, including texture, colour, sedimentary structures, and bedding contacts and thicknesses, which have in turn been further subdivided into six recurrent lithofacies. The vertical succession of lithofacies recognised throughout $\mathrm{DO} 1 \mathrm{~A} / 3 \mathrm{~A}$ and $\mathrm{BO} 1 \mathrm{~A} / \mathrm{B}$ provide the physical evidence required for paleoenvironmental interpretations, and assist in establishing depositional processes.

\section{D01A (Fig. 4.1)}

\section{Lithostratigraphic Unit One 0.0-0.3 m, Muddy Sandy Conglomerate}

LSU One is dominated by a pebble to cobble conglomerate that displays internal stratification and poor sorting of clasts. The conglomerate unit is predominantly matrix-supported, however, some pebble clasts are concentrated in lenses and locally clast-supported. Clasts are comprised of basalt pebbles that vary in shape from sub-round to sub-angular. The light yellow-brown sandy matrix consists of abundant mm-scale broken shell fragments, and the unit is bedded at the millimetre scale. LSU One is locally oxidised in parts and has a sharp, irregular lower contact with the underlying sandy mudstone.

\section{Lithostratigraphic Unit Two 0.3-0.67 m, Sandy Mudstone}

LSU Two is a friable, light yellow-brown, sandy mudstone that exhibits weak mm-scale horizontal laminations and abundant broken shell fragments, as well as dispersed basalt clasts of granule-pebble size. Clasts are typically sub-round and sub-angular in shape. LSU Two has an abrupt/sharp planar lower contact with the muddy sandy conglomerate below.

\section{Lithostratigraphic Unit Three 0.67-1.3 m, Muddy Sandy Conglomerate}

LSU Three is comprised of a light-mid yellow-brown, poorly sorted, pebble-cobble muddy sandy conglomerate that is matrix-supported. Sandy matrix material coarsens upwards throughout the unit, as does average clast size. Clasts are randomly oriented, sub-round to subangular in shape, and mostly basalt in composition. Broken shell fragments are rare, and the 
unit also displays weak mm-scale horizontal laminations. LSU Three has a sharp planar lower contact with the underlying muddy diamictite.

\section{Lithostratigraphic Unit Four 1.3-1.9 m, Muddy Diamictite}

LSU Four is a light yellow-brown muddy diamictite that is poorly sorted and displays internal stratification. The abundance of pebble-cobble-sized clasts varies with depth throughout LSU Four producing mm-cm-scale beds that alternate from clast-poor to clast-rich. Clasts are subround and sub-angular, display no preferred orientation, and are mostly basalt in composition. The unit displays weak mm-scale horizontal laminations and has a gradational lower contact with the underlying sandy diamictite.

\section{Lithostratigraphic Unit Five 2.2-.3.05 m, Sandy diamictite}

LSU Five is a clast-rich sandy diamictite that is poorly sorted and light yellow-brown in colour with rare broken shell fragments. Clasts are pebble-cobble in size, sub-round and sub-angular in shape, and are mostly basalt in composition. Clasts are randomly oriented and their dispersal is defined by a decrease in both clast size and abundance upwards. The upper $30 \mathrm{~cm}$ of LSU Five displays weak mm-cm-scale horizontal laminations with clast concentration greater at the base of the unit where the diamictite unit transitions sharply into the underlying conglomerate.

\section{Lithostratigraphic Unit Six 3.05-3.22 m, Sandy conglomerate}

LSU Six is dominated by a poorly sorted, pebble-cobble sandy conglomerate that is clastsupported and light-mid brown in colour. The conglomerate has a finer sediment texture than the overlying diamictite. Broken shell fragments are rare, and clasts are pebble-cobble in size and mostly basalt in composition and sub-angular in shape. The unit displays no obvious bedding observed/internal stratification and has a sharp, planar lower contact with the sandy mudstone below.

\section{Lithostratigraphic Unit Seven 3.22-3.62 m, Sandy Mudstone.}

LSU Seven is a sandy mudstone that is light-medium grey-brown in colour and exhibits the finest sediment texture of all the lithologies on display throughout DO1A. This mudstone consists of dispersed mm-scale broken shell fragments and randomly dispersed granulespebbles of basaltic composition. LSU Seven displays no obvious bedding features/internal stratification and has a sharp, planar lower contact with the muddy sandy conglomerate beneath. 


\section{Lithostratigraphic Unit Eight 3.73-5.43 m, Muddy sandy conglomerate}

LSU Eight is comprised of a poorly sorted, matrix-supported conglomerate that has a muddy sandy texture, light yellow-brown colour, and exhibits sediment intrusion structures of an unknown origin (probably glacial). Clasts are pebble-cobble in size, sub-round and sub-angular in shape, and are mostly basalt in composition. Broken shell fragments are dispersed within LSU Eight, and a lower contact with the underlying diamictite unit was not observed.

\section{Lithostratigraphic Unit Nine 5.43-6.43 m, Muddy Diamictite}

LSU Nine is a clast-rich muddy diamictite that is light yellow-brown in colour, poorly sorted, and contains rare mm-scale broken shell fragments. Clasts are pebble-cobble in size, sub-round and sub-angular in shape, and are mostly basalt in composition. This muddy diamictite unit is massive, i.e., exhibits no obvious bedding/internal stratification, and is cored by ice below.

\section{DO3A (Fig. 4.2)}

\section{Lithostratigraphic Unit One 0.0-0.3m, Muddy sandy conglomerate}

LSU One is dominated by a pebble to cobble conglomerate that displays internal stratification and poor sorting of clasts. This conglomerate unit is matrix-supported and clasts are comprised of basalt pebbles that vary in shape from sub-round to sub-angular. LSU One contains abundant mm-scale broken shell fragments and is bedded at the millimetre scale. The unit is locally oxidised in parts and has a sharp, planar lower contact with the underlying sandy mudstone.

\section{Lithostratigraphic Unit Two 0.3-0.5m Sandy Mudstone}

LSU Two is a very friable, light yellow-brown, sandy mudstone that exhibits weak mm-scale laminations and abundany broken shell fragments. LSU Two contains dispersed basalt clasts of granule-pebble size that are thought to indicate some apparent alignment. Clasts are typically sub-round and sub-angular in shape, and the unit has an abrupt/sharp planar lower contact with the underlying sandy diamictite.

\section{Lithostratigraphic Unit Three 0.5-1.1 m, Sandy Diamictite}

LSU Three is a clast-rich sandy diamictite that is poorly sorted, light yellow-brown in colour, and displays coarse convolute deformation features. Broken shell fragments are rare. Clasts are pebble-cobble in size, sub-round and sub-angular in shape, and are mostly basalt in composition. Clasts are randomly oriented and their dispersal is defined by a decrease in both 
clast size and abundance upwards. The base of the unit transitions sharply into the underlying conglomerate.

\section{Lithostratigraphic Unit Four 1.1-1.5 m, Muddy Sandy Conglomerate}

LSU Three is comprised of a light yellow-brown, poorly sorted, pebble-cobble muddy sandy conglomerate that is matrix-supported. Matrix material fines upwards, along with a decrease in clast concentration. Clasts are randomly oriented, sub-round to sub-angular in shape, and mostly basalt in composition. Broken shell fragments are rare, and the unit also displays weak mm-scale horizontal laminations. LSU Four has a sharp planar lower contact with the underlying sandy mudstone.

\section{Lithostratigraphic Unit Five 1.5-1.8 m, Sandy Mudstone}

LSU Five is a sandy mudstone that is light yellow-brown in colour and consists of abundant mm-scale broken shell fragments and randomly dispersed granules-pebbles of basaltic composition. LSU Five displays no obvious bedding features/internal stratification and its lower contact with the underlying sandy diamictite unit was not observed.

\section{Lithostratigraphic Unit Six 1.8-2.4 m, Sandy Diamictite}

LSU Six is a clast-rich sandy diamictite that is light yellow-brown in colour, poorly sorted, and contains abundant mm-cm-scale broken shell fragments in concentrated lenses of shell hash. Clasts are pebble-cobble in size, sub-round and sub-angular in shape, and are mostly basalt in composition. This sandy diamictite unit is massive, i.e. exhibits no obvious bedding/internal stratification, and transitions sharply into the underlying muddy sandy conglomerate.

\section{Lithostratigraphic Unit Seven 2.4-2.7 m, Muddy Sandy Conglomerate}

LSU Seven is a clast-supported, pebble-cobble conglomerate that is light yellow-brown in colour and contains concentrations of mm-scale shell hash. Clasts are sub-round and subangular in shape, and mostly basalt in composition. LSU Eight has a sharp, planar lower contact with the muddy diamictite unit below.

\section{Lithostratigraphic Unit Eight 2.7-3.65 m, Muddy Diamictite}

LSU Eight is a clast-rich muddy diamictite that is light yellow-brown in colour, poorly sorted, and contains rare mm-scale broken shell fragments in concentrated lenses of shell hash. Clasts are pebble-cobble in size, sub-round and sub-angular in shape, and are mostly basalt in 
composition. Clast concentration decreases at the base of the unit where it transitions sharply into the underlying sandy mudstone. This muddy diamictite unit is massive, i.e. exhibits no obvious bedding/internal stratification.

\section{Lithostratigraphic Unit Nine 3.65-4.0 m, Sandy Mudstone}

LSU Nine is a friable, light yellow-brown, sandy mudstone that exhibits weak mm-scale laminations and convolute deformation features, as well as rare broken shell fragments and randomly dispersed basalt clasts of granule-pebble size. Clasts are typically sub-round and subangular in shape. LSU Nine has an abrupt/sharp planar lower contact with the muddy sandy conglomerate below.

\section{Lithostratigraphic Unit Ten 4.0-5.1 m, Sandy Diamictite}

LSU Ten is a light yellow-brown sandy diamictite that varies from clast-poor at the base to clast-rich at the top of the unit. LSU Ten contains rare mm-scale shell hash and displays no obvious lower contact with the underlying muddy sandy conglomerate.

\section{Lithostratigraphic Unit Eleven 5.1-5.4 m, Muddy sandy conglomerate}

LSU Eleven is comprised of a light yellow-brown, poorly sorted, pebble-cobble muddy sandy conglomerate that is clast-supported. Clasts are randomly oriented, sub-round to sub-angular in shape, and mostly basalt in composition. Broken shell fragments are common, but no internal stratification/bedding is evident. LSU Four has no obvious lower contact with the underlying sandy diamictite unit.

\section{Lithostratigraphic Unit Twelve 5.1-6.0 m, Sandy Diamictite}

LSU Nine is a clast-rich muddy diamictite that is light yellow-brown in colour, poorly sorted, and contains rare mm-scale broken shell fragments. Clasts are pebble-cobble in size, sub-round and sub-angular in shape, randomly oriented, and are mostly basalt in composition. This muddy diamictite unit is massive, i.e., exhibits no obvious bedding/internal stratification, and is cored by ice below

B01A/B Composite Sequence (Fig. 4.3)

Lithostratigraphic Unit One 0.0-0.9 m, Sandy Diamictite 
LSU Six is a clast-rich sandy diamictite that is light brown-grey in colour, poorly sorted, and contains abundant mm-cm-scale broken shell fragments. Clasts are pebble-cobble in size, subround and sub-angular in shape, and are mostly basalt in composition. A lower contact with the underlying conglomerate was not observed.

\section{Lithostratigraphic Unit Two 0.9-1.3 m, Muddy Sandy Conglomerate}

LSU Two is dominated by a pebble to cobble conglomerate that is poorly sorted and displays no obvious internal stratification. This matrix-supported conglomerate contains abundant mm$\mathrm{cm}$-scale broken shell fragments. Clasts are randomly oriented and vary in shape from subround to sub-angular. LSU Two is locally oxidised in parts and has a sharp, planar lower contact with the underlying sandy diamictite.

\section{Lithostratigraphic Unit Three 1.3-2.3 m, Sandy Diamictite}

LSU Three is a sandy diamictite that is weakly laminated, yellow-brown in colour, poorly sorted, and contains abundant mm-cm-scale broken shell fragments. Clasts are pebble-cobble in size, sub-round and sub-angular in shape, and are mostly basalt in composition. Although clast concentration decreases with depth throughout LSU Three, the size of clasts typically increases. The unit is cored by ice below. 